PEDRO REBELLO BORTOLINI

ANOTAÇÕES SOBRE A ASSEMBLEIA-GERAL DE CREDORES NA LEI DE RECUPERAÇÃO DE EMPRESAS E FALÊNCIAS

(LEI N $\left.{ }^{\circ} 11.101 / 2005\right)$

Dissertação de Mestrado

Orientador: Professor Mauro Rodrigues Penteado

FACULDADE DE DIREITO DA UNIVERSIDADE DE SÃO PAULO SÃO PAULO 
PEDRO REBELLO BORTOLINI

\title{
ANOTAÇÕES SOBRE A ASSEMBLEIA-GERAL DE CREDORES NA LEI DE RECUPERAÇÃO DE EMPRESAS E FALÊNCIAS
}

(LEI N $\left.{ }^{\circ} 11.101 / 2005\right)$

\begin{abstract}
Dissertação apresentada à Banca Examinadora da Faculdade de Direito da Universidade de São Paulo, como exigência parcial para a obtenção do título de Mestre em Direito Comercial, sob orientação do Professor Associado Mauro Rodrigues Penteado.
\end{abstract}

FACULDADE DE DIREITO DA UNIVERSIDADE DE SÃO PAULO SÃO PAULO 
Banca Examinadora: 
A Paula, minha esposa e companheira.

A meus pais, Denise e Pedro, por tudo. 


\section{AGRADECIMENTOS}

Agradeço, em primeiro lugar, ao meu orientador, Professor Livre-Docente Mauro Rodrigues Penteado, pela atenção dispensada durante todo o mestrado. Não faria justiça se deixasse de registrar a dedicação para com os seus orientandos, que supera - e muito - a mera contribuição para redação de um trabalho acadêmico. Extremamente exigente, preocupa-se, como fazem os verdadeiramente vocacionados, com a formação integral de seus alunos, cobrando aplicação nas aulas, trabalhos, exposições e em quaisquer outras atividades, acadêmicas ou profissionais. Generoso, principia-os nos caminhos da docência, compartilhando da enorme experiência amealhada, mas sem jamais empregar tom paternalista. É louvável seu compromisso com a coisa pública, com a Universidade de São Paulo e sobretudo com o porvir. Segundo a máxima popular de que se colhe aquilo que se planta, o Prof. Mauro semeia hoje para que os próximos possam colher os frutos, o que para mim traduz, em essência, a alma de um Professor.

Agradeço a todos do corpo docente da Universidade de São Paulo nas pessoas do Professor Livre-Docente Eduardo Secchi Munhoz e do Professor Doutor Paulo Salvador Frontini, que juntamente com o Professor Mauro Rodrigues Penteado ministraram as aulas da pós-graduação que serviram de inspiração para este trabalho. Pelos três anos seguintes, ambos me dispensaram valorosa atenção, compartilhando da larga experiência acadêmica e profissional, esta indispensável para um trabalho em direito comercial.

Agradeço também ao Professor Doutor Paulo Fernando Campos Salles de Toledo, que além das valiosas aulas ministradas permitiu-me frequentar reuniões do Instituto Brasileiro de Estudos de Recuperação de Empresas - IBR, do qual é o atual presidente, e que congrega os principais estudiosos e profissionais da área do direito falimentar. Ali me foi possível conhecer, na prática, vários aspectos e questões do instituto a que me propus estudar. 
Agradeço aos colegas Álvaro Mariano e Adriana Valéria Pugliesi Gardino, já Doutores, pela colaboração e paciência para comigo quando, praticamente jejuno no direito concursal, comecei a frequentar as aulas da pós-graduação, ainda como aluno especial. Durante todo o mestrado se fizeram presentes para solucionar dúvidas, debater questões e compartilhar materiais e estudos utilizados nesta dissertação.

Agradeço ao Dr. Alfredo Sérgio Lazzareschi Neto, sempre disponível para consultas e aconselhamentos, ao Dr. Paulo Benedito Lazzareschi e aos demais advogados da banca Lazzareschi, Hilal, Bolina \& Rocha, onde adquiri grande parte da minha experiência profissional, bem como às bibliotecárias Andréia Gonçalves Silva e Nicélia Vicente de Araújo, que tantas vezes me ajudaram na obtenção dos livros e artigos citados na bibliografia.

Agradeço, por fim, ao Dr. Filipe Antônio Marchi Levada, à Dra. Paula Gonzalez da Fonseca Bortolini, à Dra. Maria Denise Parente Rebello Bortolini, ao Dr. Carlos Urquiza Scarazzato e à Dra. Camila Alcaraz Dario pelo auxílio na revisão do texto final. 


\section{ABREVIATURAS E SIGLAS}

ACC Adiantamento a contrato de câmbio para exportação

AGC Assembleia-Geral de Credores

AgRg. Agravo Regimental

AI Agravo de Instrumento

Al. Alínea

Ap. Apelação

Art. Artigo

Câm. Câmara

Cap. Capítulo

c.c. Cumulado com

CC Código Civil (Lei n. 10.406, de 10.1.2002)

CC/16 Código Civil revogado (Lei n ${ }^{\circ} 3.071$, de $1^{\circ} .1 .1916$ )

Cf. Conforme

CF Constituição da República Federativa do Brasil

Coord. Coordenador

CPC Código de Processo Civil (Lei n. 5.869, de 11.1.1973)

CTN Código Tributário Nacional (Lei n. 5.172, de 25.10.1966)

Dec. Decreto

DL Decreto-Lei

Des. Desembargador

Emb. Decl. Embargos de declaração

Emp. Empresarial

Fal. $\quad$ Falência

Inc. Inciso

j. $\quad$ Julgado em

L. Lei

LC Lei Complementar

LRF Lei de Recuperação de Empresas e Falências (Lei nº 11.101, de 2005)

LSA Lei das Sociedades por Ações

Ltda. Limitada

Min. $\quad$ Ministro 


\begin{tabular}{|c|c|}
\hline MP & Medida Provisória \\
\hline MS & Mandado de segurança \\
\hline$n^{\circ}$. & Número \\
\hline Op. cit. & Opus citatum \\
\hline p. & Página \\
\hline p. u. & Parágrafo único \\
\hline Par. & Parágrafo \\
\hline Priv. & Privado \\
\hline Proc. & Processo \\
\hline Prof. & Professor \\
\hline Publ. & Público \\
\hline PUC & Pontifícia Universidade Católica \\
\hline RDM & Revista de Direito Mercantil, Industrial, Econômico e Financeiro \\
\hline Recup. & Recuperação de empresa \\
\hline Rel. & Relator \\
\hline REsp & Recurso Especial \\
\hline Rev. & Revista \\
\hline RExt & Recurso Extraordinário \\
\hline RT & Revista dos Tribunais \\
\hline S.A. & Sociedade Anônima \\
\hline seg. & Seguintes \\
\hline STF & Supremo Tribunal Federal \\
\hline STJ & Superior Tribunal de Justiça \\
\hline t. & Tomo \\
\hline $\mathrm{T}$. & Turma \\
\hline TJDF & Tribunal de Justiça do Distrito Federal \\
\hline TJGO & Tribunal de Justiça de Goiás \\
\hline TJPR & Tribunal de Justiça do Paraná \\
\hline TJSP & Tribunal de Justiça de São Paulo \\
\hline TJRS & Tribunal de Justiça do Rio Grande do Sul \\
\hline USP & Universidade de São Paulo \\
\hline v. & Volume \\
\hline$v . g$. & verbi gratia \\
\hline v.u. & Votação unânime \\
\hline
\end{tabular}




\section{SUMÁRIO}

RESUMO.

ABSTRACT..

1. Papel dos credores no novo regime concursal brasileiro. 17

2. A evolução do direito concursal brasileiro e a AGC..

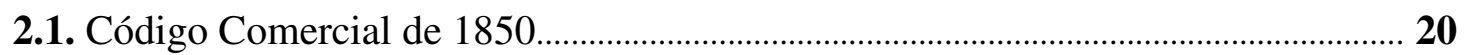

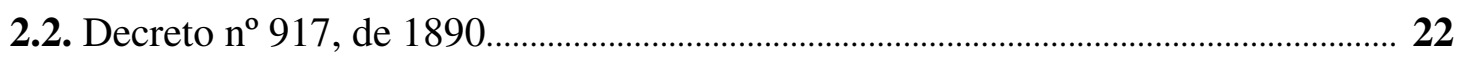

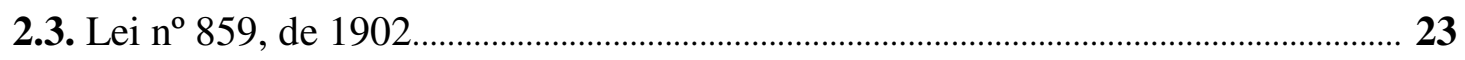

2.4. Lei $n^{\circ} 2.024$, de 1908 e Decreto $n^{\circ} 5.746$, de 1929...................................................... 24

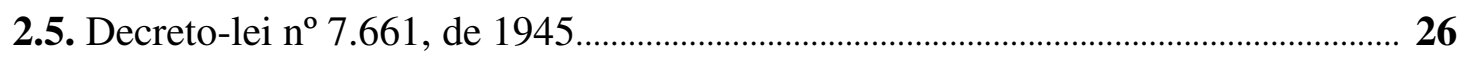

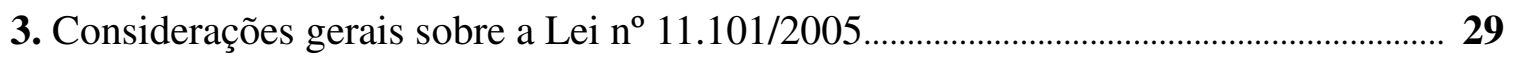

3.1. A função social da empresa e a sua preservação............................................................ 29

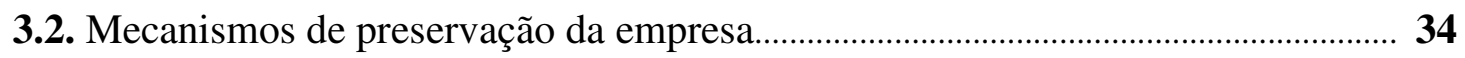

3.2.1. A preservação da empresa na recuperação judicial............................................. 34

3.2.1.1. Suspensão das ações e execuções.................................................................... 35

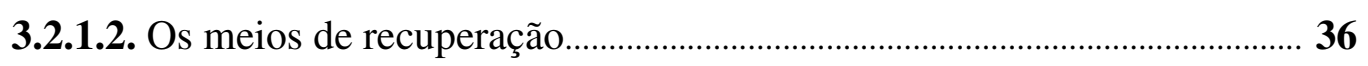

3.2.1.3. A aprovação do plano - cram down ........................................................... 38

3.2.1.4. Financiamento da recuperação........................................................................ 39

3.2.1.5. Afastamento do devedor e dos administradores............................................ 40

3.2.2. A preservação da empresa na falência....................................................................... 42

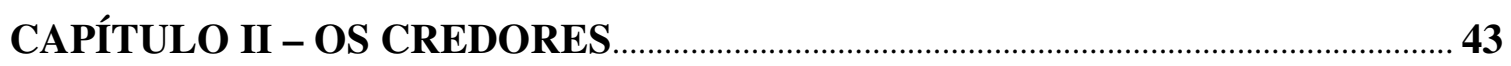

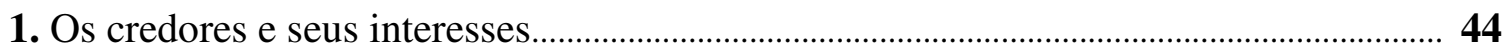

1.1. Bancos

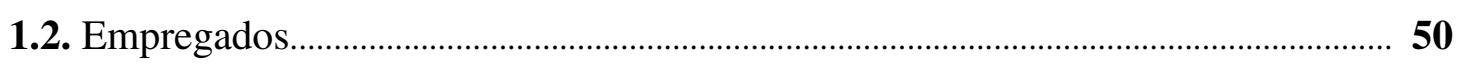

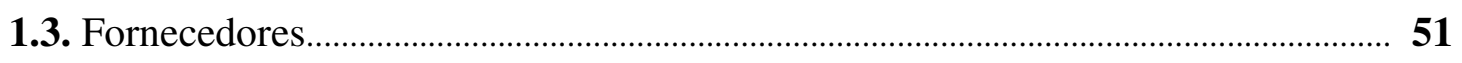

2. Credores sujeitos à recuperação judicial............................................................................. 52

2.1. A sujeição voluntária dos credores excluídos ao plano de recuperação................... 55

3. Direitos dos credores no modelo da structured bargaining ................................................. 56

3.1. Direito de aprovar ou rejeitar o plano de recuperação................................................ 58 
3.2. Direito de propor alterações ao plano de recuperação

3.3. Direito do credor com garantia real de obstar a alienação do bem objeto da garantia ou a supressão desta. 68

3.4. Direito ao tratamento isonômico na hipótese de cram down....................................... 69

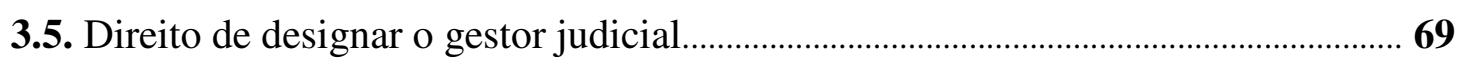

3.6. Direito de exigir a decretação da falência........................................................................ 70

3.7. Direito de participar da Assembleia-Geral de Credores................................................. 71

3.8. Direitos dos credores na falência....................................................................................... 71

3.8.1. Vantagens dos credores que financiam a recuperação......................................... 72

4. Deveres dos credores na recuperação judicial e na falência.................................................... 73

CAPÍTULO III - A ASSEMBLEIA-GERAL DE CREDORES ........................................ 75

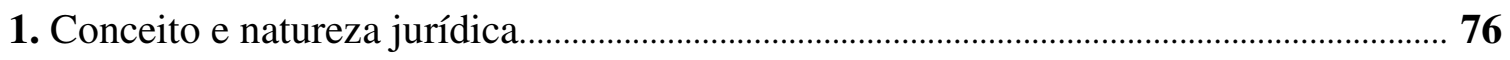

1.1. Classificação e características.................................................................................. 83

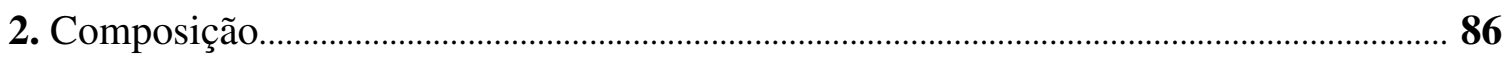

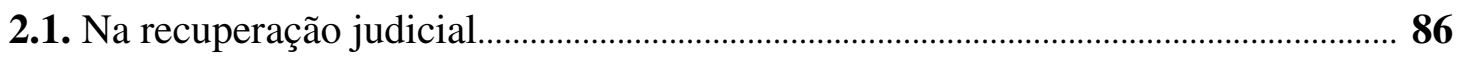

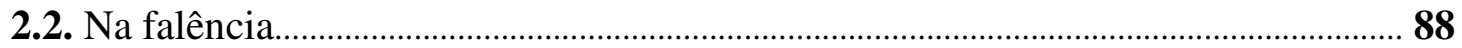

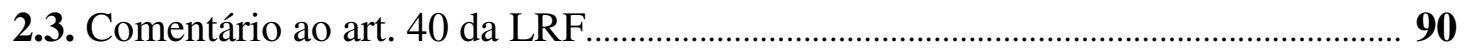

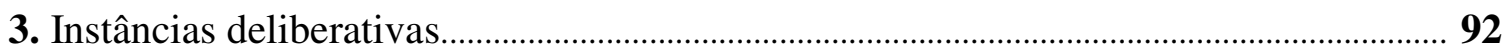

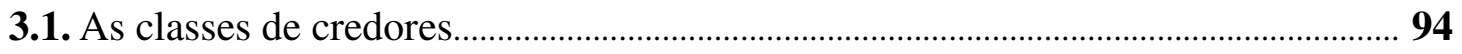

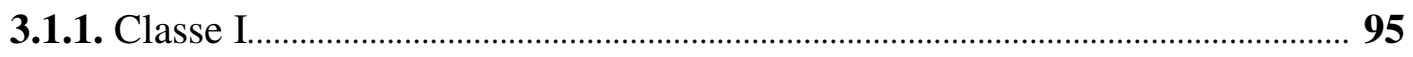

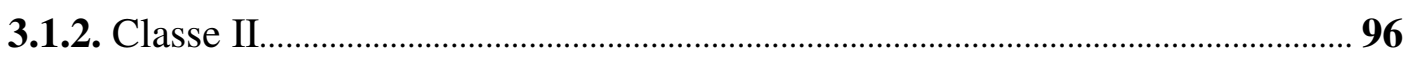

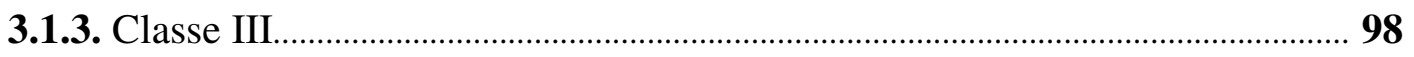

3.2. Justificativas para a divisão dos credores em classes..................................................... 104

3.3. Críticas ao modelo de divisão brasileiro............................................................................... 107

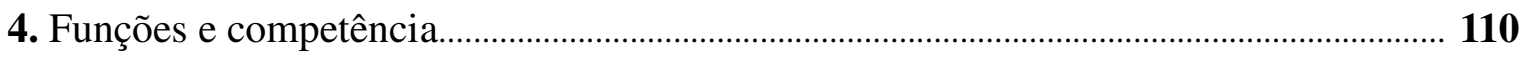

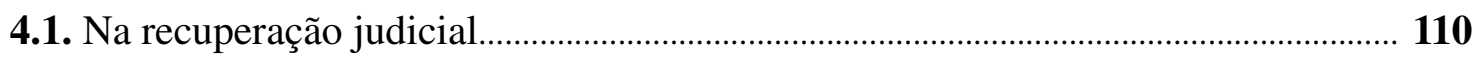

4.1.1. Aprovação, rejeição ou modificação do plano de recuperação........................... 111

4.1.2. Constituição do Comitê de Credores..................................................................................... 116

4.1.3. O pedido de desistência do devedor........................................................................ 120

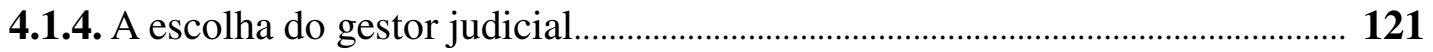

4.1.5. Qualquer outra matéria de interesse dos credores................................................. 126

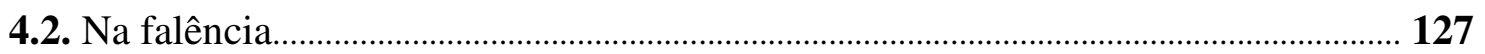

4.2.1. Constituição do Comitê de Credores....................................................................... 127 
4.2.2. Realização alternativa dos ativos do devedor.

4.2.3. Qualquer outra matéria de interesses dos credores.............................................. 132

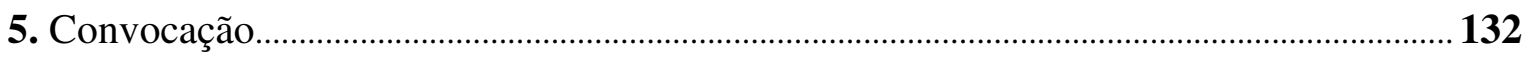

5.1. Competência para a convocação........................................................................................132

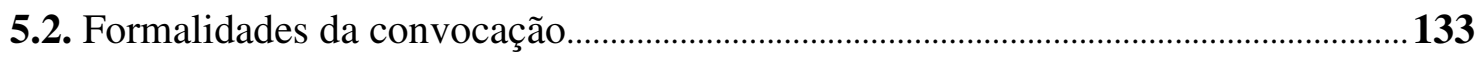

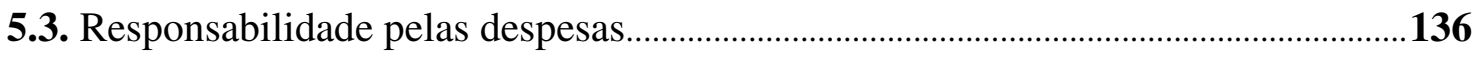

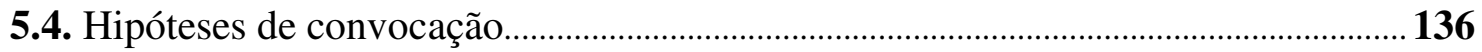

5.4.1. Convocação em razão da objeção dos credores ao plano …………………….... 137

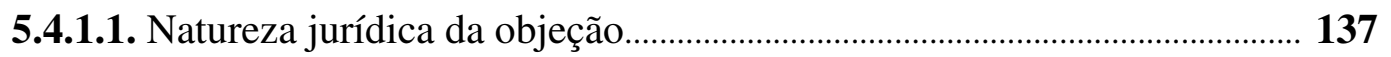

5.4.1.2. Forma da objeção: é necessário fundamentar? ............................................ 139

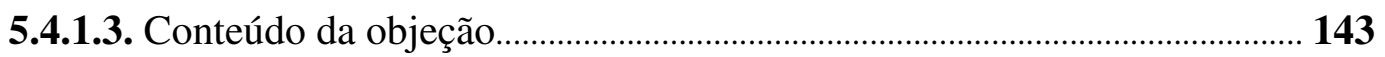

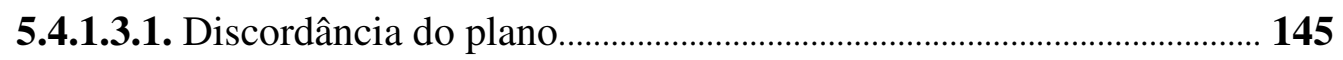

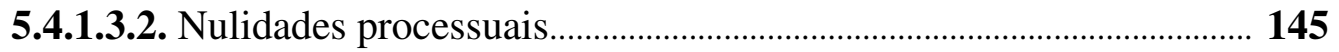

5.4.1.3.3. Causas impeditivas da recuperação........................................................... 146

5.4.1.3.4. Invalidade do plano de recuperação............................................................ 147

5.4.1.3.5. Ineficácia do plano de recuperação......................................................... 149

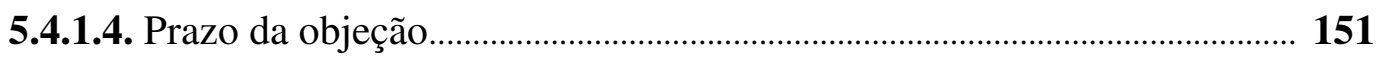

5.4.1.5. Credores legitimados a manifestar a objeção.................................................. 152

5.4.1.6. Obrigatoriedade da convocação da AGC....................................................... 156

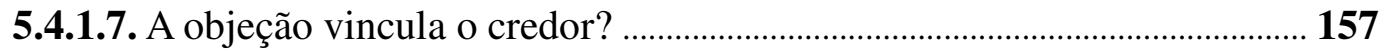

5.4.1.8. Efeitos da ausência de objeções....................................................................... 158

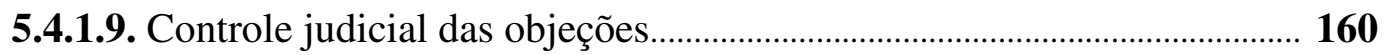

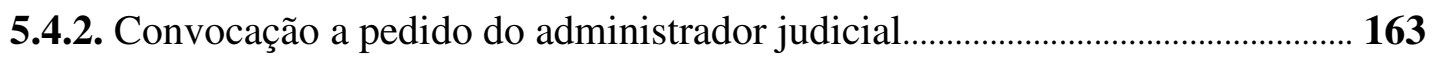

5.4.3. Convocação a pedido do Comitê de Credores........................................................ 164

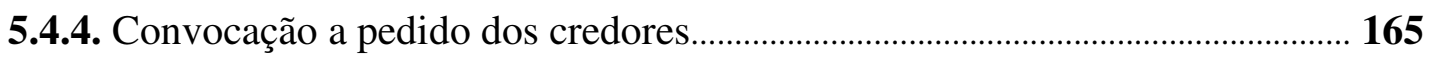

5.4.5. Convocação em razão do afastamento do devedor................................................. 165

5.4.6. Convocação por conveniência do juiz..................................................................... 166

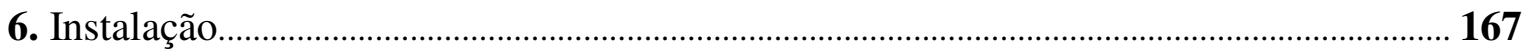

6.1. Quórum de instalação na recuperação judicial................................................................. 170

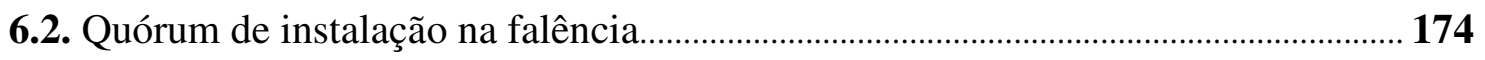

7. Presidência

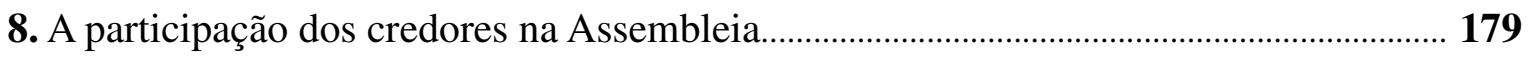

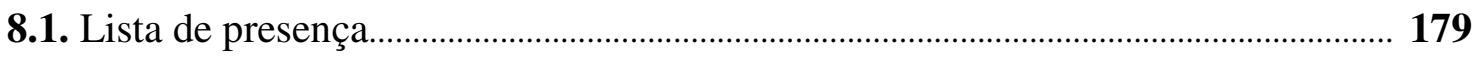

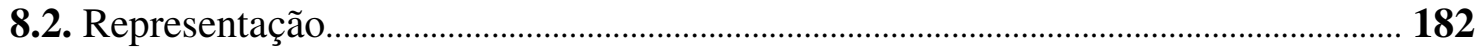


8.2.1. Pelo mandatário

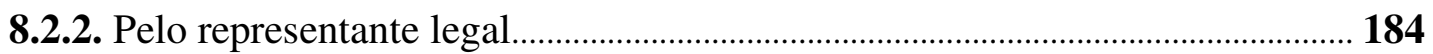

8.2.2.1. Hipóteses de efetiva representação legal....................................................... 184

8.2.2.2. A "representação" da sociedade por seus administradores.......................... 186

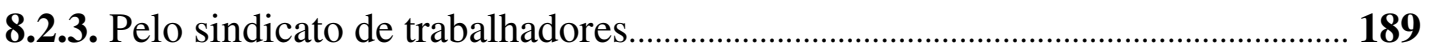

8.3. Direitos dos credores na AGC

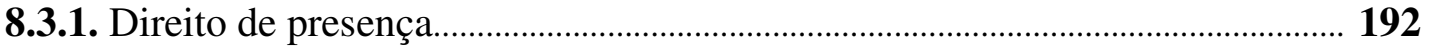

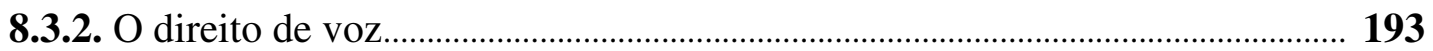

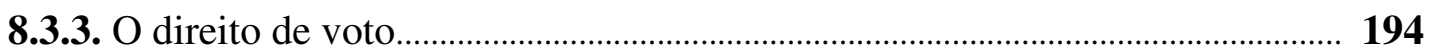

8.3.3.1. Vedação à negociação do voto........................................................................... 198

8.3.3.2. Cômputo do voto.............................................................................................. 201

8.3.3.2.1. O voto do titular de crédito em moeda estrangeira........................... 203

8.3.3.3. Credores sem direito de voto............................................................................. 204

8.3.4. O direito de protestar.................................................................................................... 207

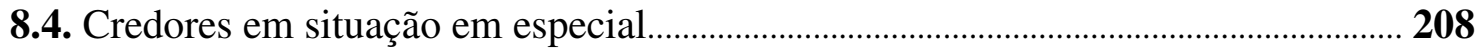

8.4.1. Credor que não teve o valor ou as condições originais de pagamento do seu crédito alterados pelo plano de recuperação.

8.4.2. Credores com vinculação societária ou de parentesco com o devedor, seu sócio ou controlador............................................................................... 211

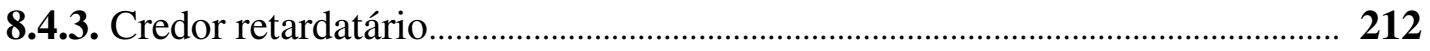

8.4.4. Credores excluídos dos efeitos da recuperação judicial........................................ 215

9. Deliberação da Assembleia-Geral de Credores........................................................................... 218

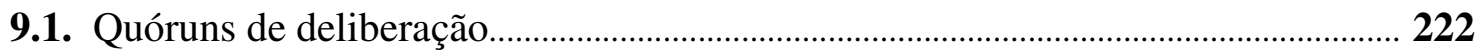

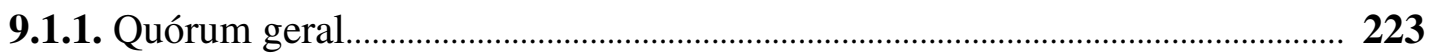

9.1.2. Quórum especial - aprovação do plano de recuperação...................................... 225

9.1.3. Quórum especial - constituição do Comitê de Credores........................................ 226

9.1.4. Quórum especial - aprovação de forma alternativa de liquidação.................... 226

9.2. A deliberação sobre o plano de recuperação...................................................................... 227

9.2.1. "Cram down" - críticas ao modelo brasileiro........................................................... 227

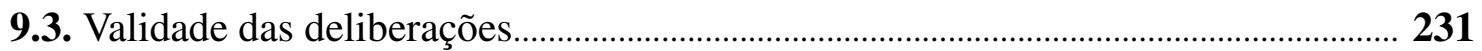

9.4. Eficácia das deliberações........................................................................................... 233

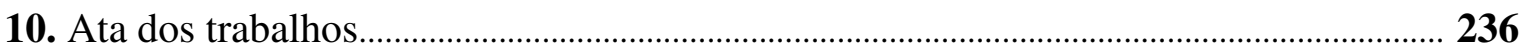


1. Controle judicial das deliberações e abuso do direito de voto.................................................. 240

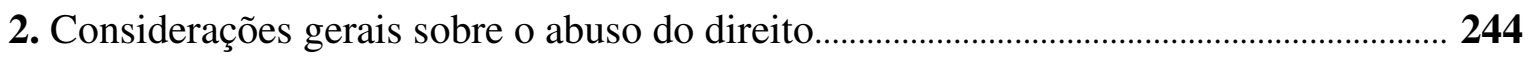

2.1. Origem da noção do abuso do direito............................................................................. 245

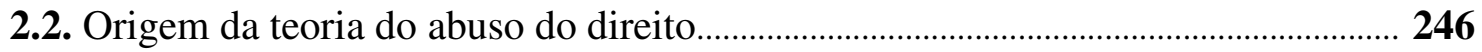

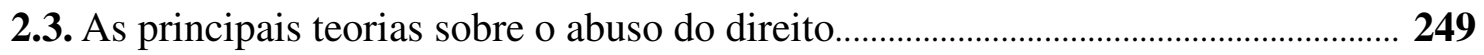

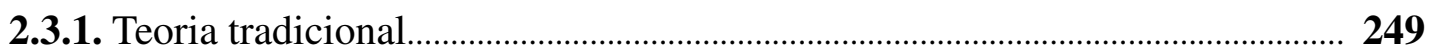

2.3.2. Teoria do conflito de direitos.................................................................................... 250

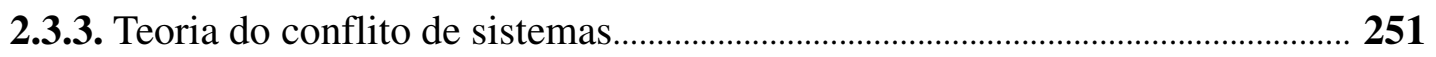

2.3.4. Abuso como violação da função social do direito subjetivo................................ 251

2.3.5. Abuso como violação do princípio da boa-fé............................................................ 252

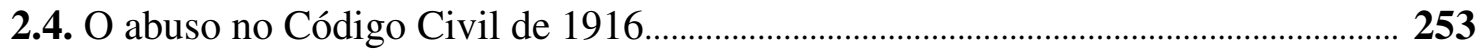

2.5. O abuso no Código Civil de 2002 ………………………………………………………..... 255

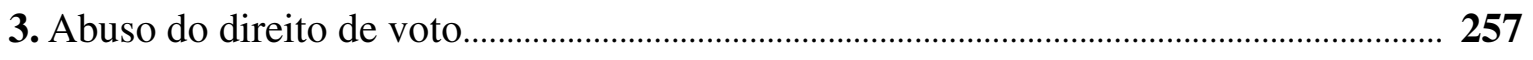

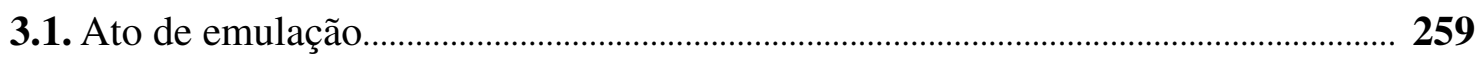

3.2. Conflito de interesses.................................................................................................... 260

CAPÍTULO V - CONSIDERAÇÕES FINAIS …………................................................... 264

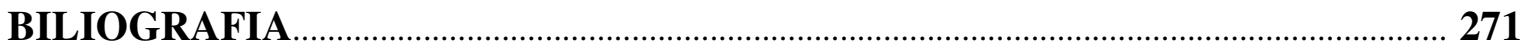

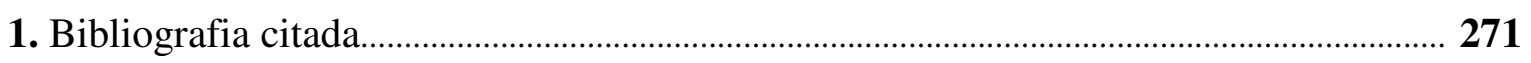

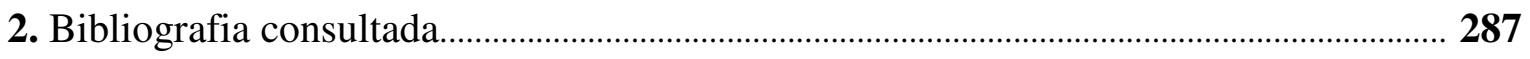




\section{RESUMO}

A Lei $\mathrm{n}^{\circ}$. 11.101, de 9 de fevereiro de 2005, alterou significativamente o regime jurídico da insolvência da empresa, atribuindo nova importância aos credores: de meros espectadores passaram à condição de protagonistas do processo concursal, com a prerrogativa de decidir a solução a ser dada à crise do devedor comum (seja pela via da recuperação, seja pela da falência).

A vontade coletiva dos credores passa a ser determinada no âmbito da AssembleiaGeral de Credores, órgão caído em desuso na vigência do Decreto-Lei no 7.661/45, mas que desempenha, no regime atual, funções de extremada importância.

No processo da recuperação judicial, cabe à Assembleia-Geral de Credores deliberar sobre a aprovação, rejeição ou modificação do plano de recuperação apresentado pelo devedor, a constituição do Comitê de Credores, o pedido de desistência do devedor, a escolha do gestor judicial, bem como sobre quaisquer outras matérias que possam afetar os interesses dos credores. Já no âmbito da falência, incumbe-lhe, principalmente, decidir sobre a forma de liquidação dos ativos do devedor, a fim de maximizar o seu valor e conferir celeridade e eficiência ao processo.

Por opção legislativa, não competirá ao Judiciário julgar a viabilidade econômica da empresa em crise ou decidir sobre a conveniência da recuperação ou da falência (isso é papel dos credores). A importância do juiz, nesse contexto, passa a ser outra, sobretudo para garantir que a negociação do devedor com os credores (e entre os próprios credores) seja conduzida de acordo com as formalidades e os princípios da lei, de modo a conferir legitimidade às deliberações tomadas. Além disso, caberá ao juiz tentar prevenir e, se necessário, reprimir o abuso pelo devedor e pelos credores das prerrogativas e direitos que lhes foram conferidos.

Em linhas gerais, serão essas as matérias versadas nesta dissertação, que se propõe a analisar a situação jurídica dos credores e a sistemática da Assembleia-Geral, com algumas considerações acerca do controle judicial em face do abuso do direito de voto.

Palavras-chave: Falência, Recuperação judicial, Assembleia-Geral de Credores. 


\begin{abstract}
Law no. 11.101, dated February 9, 2005, significantly changed the legal system of company's insolvency, giving new importance to the creditors: from spectators in the past, they became protagonists of the insolvency process, with the prerogative to decide about the solution to be given to the common debtor crisis (either through reorganization or bankruptcy).

The creditor's collective will shall now be determined under the General Meeting of Creditors, organ fallen into disuse during the rule of Decree-Law no. 7.661/45, but that now plays, in the current system, functions of extreme importance.

In the reorganization process, it is up to the General Meeting of Creditors to decide on the approval, rejection or modification of the plan submitted by the debtor, the constitution of the Creditors Committee, the waiver request of the debtor, the choice of a judicial manager, as well as on any other matters that may affect the interests of creditors. On the other hand, regarding to bankruptcy, the General Meeting of Creditors must, above all, decide how to liquidate the debtor's assets, in order to maximize their value and give speed and efficiency to the process.

Due to legislative choice, it will not compete to the Courts to judge the economic viability of the company in crisis or to rule on the convenience of reorganization or bankruptcy (this is the role of the creditors). The importance of the judge in this context is now different, mainly to ensure that the negotiation between creditors and debtor (and among the creditors) is conducted in accordance with the procedures and principles of law, in order to give legitimacy to the resolution taken. Furthermore, it will be up to the judge to try to prevent and, if necessary, restrain the abuse, by debtor and creditors, of the rights and privileges conferred to them.
\end{abstract}

In general, these are the matters that will be versed in this thesis, which proposes to analyze the legal status of creditors and the systematics of the General Meeting, with some considerations on judicial review of the abuse of the right to vote.

Keywords: Bankruptcy, Judicial reorganization, General Meeting of Creditors. 
CAPÍTULO I - INTRODUÇÃO 


\section{CAPÍTULO I - INTRODUÇÃO}

\section{Papel dos credores no novo regime concursal brasileiro}

A Lei $n^{\circ}$. 11.101, de 9 de fevereiro de 2005 (LRF), estabeleceu novo regime jurídico para a falência e para a recuperação de empresas em crise, retomando - ainda que com diferenças significativas - sistema que vigorou no Brasil na primeira metade do século $\mathrm{XX}^{1}$ e que é hodiernamente adotado por algumas das principais economias mundiais.

Segundo esse sistema, faculta-se aos credores participar de importantes decisões que envolvem a empresa em crise, seja para permitir a recuperação do devedor, determinar a forma de liquidação dos seus bens, ou ainda para resolver qualquer outra matéria que possa afetar os interesses que tiverem. Algo muito diferente do que havia no regime do Decreto-Lei $\mathrm{n}^{\circ}$. 7.661, de 21 de junho de 1945, em que a vontade dos credores tinha pouca ou nenhuma relevância, sobretudo para o deferimento da concordata preventiva $^{2}$, atualmente extinta ${ }^{3}$.

Agora o futuro da empresa em crise sujeita-se à vontade dos credores, a ser definida, salvo nos casos de dispensa legal, no âmbito da Assembleia-Geral de Credores, objeto central do presente estudo.

\footnotetext{
${ }^{1}$ Cf. Mauro Rodrigues Penteado. In: SOUZA JUnior, Francisco Satiro; e PITOMbo, Antonio Sergio A. de Moraes (Coords.). Comentários à Lei de Recuperação de Empresas e Falência. S. Paulo: RT, 2005, p. 56 e 61-65.

${ }^{2} \mathrm{Na}$ vigência do Decreto $\mathrm{n}^{\circ}$. 7.661/45, a concessão da concordata dependia apenas do preenchimento de certos requisitos contábeis e outros de natureza pessoal do devedor, podendo ser deferida mesmo contra a vontade dos credores, conforme ressalta FÁBIO KONDER COMPARATO: “... a atual Lei de Falências introduziu, pela primeira vez ao que parece na legislação universal, a ação de concordata, que pode ser julgada procedente pelo magistrado sem, e até mesmo contra, a vontade manifesta dos credores, o que provocou as iras de Waldemar Ferreira ("concordata fascista")." (Aspectos jurídicos da macro-empresa. São Paulo: RT, 1970, p. 99).

${ }^{3}$ Ressalvada a aplicação da norma de direito intertemporal disposta no art. 192 da Lei no 11.101/2005: "Esta Lei não se aplica aos processos de falência ou de concordata ajuizados anteriormente ao início de sua vigência, que serão concluídos nos termos do Decreto-Lei no 7.661, de 21 de junho de 1945."
} 
Instituto de pouca utilidade ${ }^{4}$ e caído em desuso na vigência do Decreto-Lei $\mathrm{n}^{\circ}$. 7.661/45, a Assembleia-Geral de Credores passa a desempenhar, no regime vigente, funções de extremada importância, tanto no processo da recuperação judicial (alternativa criada pela lei para o devedor em crise) quanto no da falência.

Conforme o art. 35, I, da LRF, cabe à Assembleia-Geral de Credores deliberar, na recuperação judicial, sobre a aprovação, rejeição ou modificação do plano de recuperação apresentado pelo devedor, a constituição do Comitê de Credores, o pedido de desistência do devedor, a escolha do gestor judicial, bem como sobre quaisquer outras matérias que possam afetar os interesses dos credores.

Já no âmbito da falência, incumbe à Assembleia-Geral de Credores decidir, principalmente, sobre a forma de liquidação dos ativos do devedor, a fim de maximizarlhes o valor e conferir celeridade e eficiência a esse processo (LRF, art. 35, II, “c”).

Nota-se, pois, a enorme importância que a nova lei atribuiu aos credores: de meros espectadores passaram à condição de protagonistas do processo concursal ${ }^{5}$, determinando, conforme os seus interesses, a solução para a crise do devedor comum (seja pela via da recuperação, seja pela da falência).

Engana-se, porém, quem pensa que esse sistema (de relegar aos credores a decisão sobre o futuro do devedor) constitui novidade para o direito brasileiro. Na verdade, era essa a tração do direito brasileiro, só abandonada com a edição do Decreto-Lei $\mathrm{n}^{\circ}$ 7.661, em 1945.

\footnotetext{
${ }^{4}$ Cf. JORGE LOBO, “a revogada Lei de Quebras praticamente baniu a assembléia geral de credores no processo de falência, mantendo-a apenas nos raros casos dos arts. 122 e 123, $\S 3^{\mathbf{o}}$ ". (In: ToLEDO, Paulo Campos Salles de; e ABRÃO, Carlos Henrique (coords.). Comentários à Lei de Recuperação de Empresas e Falência. São Paulo: Saraiva, 2005, p. 85). Os casos dos arts. 122 e 123 do Decreto no $7.661 / 45$ permitiam a convocação da Assembléia de Credores apenas para deliberar sobre a forma de liquidação do ativo, o que quase nunca ocorria, especialmente porque a fase de liquidação era relegada para o final do processo falimentar, após o relatório do síndico. A esta altura, boa parte dos bens do devedor - especialmente aqueles empregados em processos produtivos - já estava deteriorada, defasada tecnologicamente, ou simplesmente desvalorizada, desestimulando qualquer outra forma de alienação que não a venda em leilão judicial.

${ }^{5}$ Eis aí mais uma expressão daquilo que FÁBIO KONDER COMPARATO chamou de "dualismo pendular" do direito concursal brasileiro: "Em nosso país, a legislação falimentar tem seguido um ritmo nitidamente pendular: protege-se alternadamente o insolvente, ou os seus credores, ao sabor da conjuntura econômica e da filosofia política do momento." (Aspectos jurídicos...Op. cit., p. 98).
} 
À semelhança do que ocorre com a Lei ${ }^{\circ}$ 11.101/2005, todos os diplomas falimentares anteriores ao referido decreto estabeleciam a realização de algum tipo de reunião entre os credores para deliberar sobre as alternativas à quebra do devedor, podendo-se neles identificar as origens da "Assembleia-Geral de Credores" no direito brasileiro.

Daí a importância de conhecer e estudar esses diplomas, para mais bem compreender a atual sistemática da assembleia e os problemas que ela encerra.

\section{A evolução do direito concursal brasileiro e a Assembleia-Geral de Credores}

Colhendo influências do direito romano (sobretudo da missio in bona, da bonorum venditio e da bonorum cessio) ${ }^{6}$, o direito falimentar teria se desenvolvido na Idade Média como processo de execução coletiva dos bens do devedor insolvente, com fortes traços penais. Em síntese, a falência era vista como delito e o falido como criminoso $^{7}$.

Durante séculos, o principal objetivo do direito falimentar foi o de tornar mais célere, seguro e eficiente o procedimento de liquidação dos bens do devedor, não se cogitando da preservação da empresa. Esta só seria uma preocupação do período posterior à $1^{\text {a }}$ Guerra Mundial, marcado por grave crise do setor industrial ${ }^{8}$.

A partir de então, passou a ser reconhecida a importância das empresas para o desenvolvimento econômico e social das nações, observando-se que, além de gerar riqueza para os seus titulares, elas contribuíam de modo significativo para o incremento da

\footnotetext{
${ }^{6}$ A missio in bona consistia no desapossamento dos bens do devedor em razão de sua fuga ou banimento, os quais eram custodiados pelo credor, para posterior venda, sob a ordem e controle do magistrado (bonorum venditio). A bonorum cessio, por sua vez, era procedimento destinado ao "devedor infeliz, cuja impossibilidade de pagar não advinha de truculência ou improbidade, mas do infortúnio em seus negócios". Em síntese, permitia que "o devedor insolvente, sem culpa, abandonasse seu patrimônio aos credores, para saldar suas dívidas", sendo esta a origem da concordata preventiva da falência, na Idade Média. (Cf. RUBENS REQUĩ̃o. Curso de Direito Falimentar. São Paulo: Saraiva, 1980, v. 1, p. 8).

${ }^{7}$ Ao ponto de, na França, o falido ser obrigado a "usar o boné verde dos forçados, a fim de que não se tornasse esquecido". SAMPAIO DE LACERDA relata que vestígios dessa prática podem ser observados nas fábulas de LA Fontaine e nas sátiras de BoILEAU (Manual de Direito Falimentar. Rio de Janeiro: Freitas Bastos, 1972, p. 29).

${ }^{8}$ Cf. Nelson ABRÃo. Curso de Direito Falimentar. São Paulo: Leud, 1997, p. 32.
} 
produção, geração de empregos, recolhimento de impostos etc. Constatou-se, pois, que a empresa desempenha relevante função social, merecendo, por isso, ser preservada.

Datam dessa época as primeiras leis destinadas a obstar a falência e preservar a empresa, como, por exemplo, a lei espanhola de 26.7.1942 (que concedia ao devedor dilação de prazo para o cumprimento de suas obrigações), o Vergleichsordnung alemão de 1935 e o Chandler Act norte-americano, de 1938 (que previam a celebração de "acordos preventivos"). Conforme classificação proposta por NELSON ABRÃO, essas leis marcam a segunda fase do direito falimentar' .

No Brasil, ao menos desde a edição do Código Comercial, em 1850, existem instrumentos legais para evitar-se a quebra ${ }^{10}$. Até a edição do Decreto $n^{\circ}$. 7.661/45, porém, todos eles dependiam da concordância de determinado percentual dos credores, quase sempre manifestada em algum tipo de assembleia.

\subsection{Código Comercial de 1850}

Pode-se afirmar que o Código Comercial de 1850 (Lei no 556, de 25-06$1850)^{11}$ inaugurou a primeira fase histórica da falência no direito brasileiro ${ }^{12}$, antes inserta em verdadeiro "caos legislativo",

\footnotetext{
${ }^{9}$ Idem, p. 32.

${ }^{10}$ CARvalho De MendonÇA conta que, antes da edição do Código Comercial de 1850, vigorou no Brasil a legislação portuguesa sobre quebras, que sofreu "profundas modificações, desde que a lei de 30 de outubro de 1823 mandou observar a de 18 de agosto de 1769, que determinava se guardassem nos negócios mercantis e marítimos, como subsidiárias, as leis das nações civilizadas da Europa. As disposições do Código Comercial francês eram preferidas às das leis portuguesas, para regularem e decidirem todas as questões originadas das falências" (Tratado de Direito Comercial brasileiro. 5 ed. Rio de Janeiro: Freitas Bastos, 1954, v. 7, p. 62). Para uma exposição detalhada sobre a legislação falimentar anterior ao Código Comercial de 1850, confira-se ADRIANA VALÉRIA PUGLIESI GARDINO. A evolução do tratamento jurídico da empresa em crise. Dissertação de mestrado. São Paulo: Faculdade de Direito da USP, 2006.

${ }^{11}$ Cf. TRAJANO DE MiRAnda VAlverde, "no seu percurso até a República, foi o Código Imperial sofrendo algumas alterações, provocadas quase totalmente por situações urgentes a resolver. Dão disso testemunho os decretos 3.308 e 3.309, de 1864, revogados pelo de n. 3.516, de 30 de setembro de 1865 . O decreto de $n$. 3.065, de 6 de Maio de 1882, modificou os artigos 844 e 845 do Código, e instituiu a concordata por abandono" (A fallencia. Rio de Janeiro: Freitas Bastos, 1931, p. 25).

${ }^{12}$ Cf. TRAJANO DE MIRANDA VALVERDE. A fallencia. Rio de Janeiro: Freitas Bastos, 1931, p. 25.

${ }^{13}$ Cf. PAULO M. DE LACERDA. Da fallencia no direito brasileiro. São Paulo: Editora Nacional, p. 7.
} 
Como forma de evitar a quebra, previa a moratória e a concordata, ambas subordinadas à concordância dos credores, que deviam manifestá-la em reunião especialmente designada, à semelhança do que ocorre no regime da atual lei falimentar.

A moratória - de no máximo 3 (três) anos - podia ser requerida pelo comerciante que provasse ter ficado impossibilitado de satisfazer de pronto as obrigações contraídas em razão de acidentes extraordinários imprevistos, ou de força maior, mas possuindo fundos bastantes para pagar integralmente a todos os seus credores, mediante alguma espera (art. 898).

Cabia ao Tribunal do Comércio decidir sobre o pedido de moratória, mas esta só poderia ser concedida mediante a concordância da maioria dos credores em número, representantes de pelo menos dois terços da totalidade das dívidas sujeitas aos efeitos da moratória (apenas créditos quirografários). A vontade dos credores era conhecida em sessão especialmente convocada pelo Tribunal, na forma do art. 900.

A concordata, por sua vez, consistia em acordo oferecido pelo devedor aos seus credores (art. 842), que se aprovado fazia suspender os efeitos da sentença de quebra (cuidava-se, pois, de uma concordata "suspensiva", não preventiva). A apreciação desse acordo fazia-se em reunião dos credores presidida pelo juiz comissário (escolhido entre os Deputados comerciantes integrantes do Tribunal do Comércio).

A sistemática prevista no Código Comercial para essas reuniões de credores era complexa, lenta e dispendiosa ${ }^{14}$, valendo destacar a existência de reuniões prévias à deliberação da concordata para definirem-se os credores admitidos à votação (arts. 845 e 846). Em determinados casos de contestação, o Código previa até o adiamento da deliberação sobre a concordata para que antes se decidisse se determinado credor poderia ou não votar (arts. 846, p.u., e 847).

\footnotetext{
14 “Com efeito, o nosso processo das falências, lento, complicado e dispendioso, importa sempre a ruína do falido e o sacrifício do credor. Uma dolorosa experiência tem demonstrado que os credores, apesar das fraudes de que são vítimas, descoroçoados do resultado, abstem-se desses processos eternos, e querem antes aceitar concordatas, as mais ruinosas e ridículas." (CARVALHO DE MENDONÇA. Das fallencias e dos meios preventivos de sua declaração. São Paulo: Typografia Brazil de Carlos Gerke \& Cia., 1899, v. 1, p. 7).
} 
Finalmente, uma vez definidos os créditos admitidos à votação, passava-se à deliberação do projeto de concordata apresentado pelo devedor, considerando-se aprovado mediante o voto favorável da maioria dos credores em número, representantes de pelo menos dois terços da totalidade das dívidas sujeitas aos efeitos da concordata (art. 847). Uma vez concedida, a concordata obrigava todos os credores ${ }^{15}$, mesmo aqueles dissidentes da deliberação que a aprovou (art. 852).

Essa mesma sistemática também era empregada para a deliberação do chamado “contrato de união" (art. 847), mediante o qual, à falta de proposta de concordata pelo devedor, os credores poderiam definir a forma de liquidação dos seus ativos.

\subsection{Decreto $\mathrm{n}^{\circ}$ 917, de 1890}

Revogando a terceira parte do Código Comercial de 1850, o Decreto 917, de 24 de outubro de 1890, também previa concessão de moratória ao devedor, aplicável somente às dívidas quirografárias, mediante o cumprimento de exigências parecidas com as do diploma anterior (arts. 107 e 116). O prazo máximo da moratória era de apenas um ano, podendo ser prorrogado uma única vez, por igual período, caso o credor tivesse pagado pelo menos $50 \%$ do principal (arts. 112 e 119).

O mesmo decreto previa ainda outras formas de prevenir a falência, como o acordo extrajudicial com os credores (art. 120), a concordata preventiva (art. 130) e a cessão de bens (art. 131). À exceção desta última, todas as demais (inclusive a moratória) ficavam sujeitas à aprovação dos credores, competindo ao juiz apenas homologar a decisão que tomassem em assembleia. Somente no tocante à cessão de bens, cabia ao juiz poder propriamente decisório, devendo rejeitá-la se verificasse má-fé do devedor (art. 135).

O Decreto $n^{\circ}$ 917/1890 inaugurou a chamada "concordata preventiva", que efetivamente obstava o decreto da falência e não somente suspendia os efeitos da quebra, como se dava no regime anterior (embora a concordata "suspensiva" ainda se fizesse presente no regime do Decreto $n^{\circ}$ 917/1890).

\footnotetext{
${ }^{15}$ Exceção feita aos credores do domínio (art. 874), os privilegiados (art. 876) e os hipotecários (art. 879), conforme art. 852 do Código Comercial.
} 
A concordata preventiva, quando realizada judicialmente, dependia da aprovação dos credores em assembleia, que deveria seguir, no que fosse cabível, a mesma sistemática prevista para a aprovação da concordata suspensiva (art. 130). A dinâmica dessa reunião, todavia, não era bem explicada pelo Decreto $n^{\circ}$ 917/1890, que basicamente se limitava a determinar que os credores deveriam ser convocados com pelo menos oito dias de antecedência, indicando-se em resumo os termos da proposta.

Interessante observar que, a par da concordata judicial, o Decreto $\mathrm{n}^{\circ}$ 917/1890 também admitia - com o evidente propósito de agilizar, simplificar e reduzir custos - que o acordo do devedor com os credores fosse feito extrajudicialmente, mediante a concordância dos representantes de pelo menos três quartos da totalidade do passivo. Nessa hipótese, a petição de acordo deveria ser imediatamente ("sem demora") submetida à homologação judicial (art. 120).

Em caso de falência, o Decreto $n^{\circ}$ 917/1890 previa a reunião dos credores para aprovação da concordata suspensiva ou, se não houvesse proposta do devedor ou fosse ela rejeitada, para eleger dois ou mais síndicos e uma comissão fiscal de três membros, ficando instituído nesse caso o já referido "contrato de união". Aos primeiros cabia proceder à liquidação definitiva da massa, enquanto que à comissão fiscal competia funções consultivas e deliberativas (art. 58), que incluíam a decisão sobre forma de liquidação dos ativos, a transação sobre as dívidas e negócios da massa até a venda de todo fundo de comércio para uma só pessoa, ainda que ao próprio falido (art. 60).

\subsection{Lei no 859, de 1902}

O Decreto 917, de 24 de outubro de 1890 , veio a ser revogado pela Lei $\mathrm{n}^{\circ} 859$, de 16 de agosto de 1902, previa apenas a concordata preventiva como forma de obstar a falência (art. 114), embora mantivesse a concordata suspensiva (art. 51).

A concessão da concordata preventiva dependia da aceitação dos credores quirografários, variando o quórum de aprovação conforme fossem as condições do acordo oferecido pelo devedor (arts. 117 e 54). Desde que aprovado por três quartos dos credores, representantes de três quartos do valor somado dos créditos, o prazo para pagamento das dívidas poderia ser superior a 2 (dois) anos. 
Não havia previsão, entretanto, de assembleia ou reunião para que os credores deliberassem sobre a concordata preventiva. Estes, uma vez intimados por carta e pela imprensa acerca da proposta de concordata, deveriam remeter ao juiz o seu voto (de aceitação ou recusa), por escrito, no prazo dez dias (art. 116), restringindo-se a realização de reunião para a deliberação da proposta da concordata suspensiva ou da forma de liquidação (art. 48).

Curioso observar a preocupação da lei com os conluios fraudulentos entre credores e o devedor (art. 118), chegando a punir, com a perda do crédito, o credor que, nas deliberações sobre a concordata, transigisse com o seu voto para obter vantagem indevida para si (art. 62, parágrafo único). Paradoxalmente, essa mesma lei é historicamente conhecida pela quantidade de fraudes que ensejou ${ }^{16}$, notadamente pela forma de eleição do síndico provisório e da comissão fiscal, indicados pelas juntas comerciais ${ }^{17}$.

\subsection{Lei no 2.024 , de 1908 e Dec. $n^{0} 5.746$, de 1929}

Editada com o propósito de acabar com as fraudes cometidas na égide da Lei ${ }^{\circ}$ 859/1902, a Lei $\mathrm{n}^{\mathrm{o}} 2.024$, de 17 de dezembro de 1908, elaborada por Carvalho de Mendonça, também facultava ao devedor pleitear concordata preventiva (art. 149), devendo fazê-lo por requerimento motivado do qual constasse a exposição do seu estado econômico, as garantias oferecidas para o pagamento de mais de $20 \%$ dos créditos quirografários, bem como as cláusulas e condições em que pretendia cumprir suas obrigações.

Em assembleia presidida pelo juiz, os credores deliberavam sobre a proposta de concordata (art. 154, $\S 2^{\circ}$ ). Obtida aprovação unânime, o juiz homologava a concordata na própria assembleia. Porém, em havendo credores dissidentes, a concessão da concordata dependia da obtenção de certos quóruns de aprovação, que variavam conforme fossem as

\footnotetext{
16 “ a Lei n. 859, de 16 de agosto de 1902, aboliu a moratória e a cessão de bens, conservando a concordata preventiva, mas regulamentou-a de modo a dar entrada à mais deslavada fraude. Não houve melhora ao estado de coisas, estabelecido no Dec. n. 917; ao contrário, talvez se tornasse mais fácil a obtenção de indecorosos conchavos, sob o nome de concordata preventiva”. (Carvalho de Mendonça. Tratado de Direito Comercial Brasileiro. São Paulo: Freitas Bastos, 1955, v. 8, p. 488).

${ }^{17}$ Cf. WAldemar FerReIRA. Instituições de direito comercial. São Paulo: Max Limonade, 1955, v. 5, p. 25. "O número de nomes [que poderiam ser indicados para o conselho fiscal] variaria com a importância das cidades: 40 seriam os do Distrito Federal, logo alcunhados de 'os 40 ladrões' e o síndico provisório de 'Ali Babá’”.
} 
condições de pagamento oferecidas pelo devedor (art. 106). Em nenhum caso o prazo para pagamento dos credores podia superar 2 (dois) anos (art. 106, § $1^{\circ}$ ).

A Lei n 2.024/1908 continha um título especialmente dedicado à AssembleiaGeral de Credores (arts. 100 a 102).

Entre as suas disposições, destaca-se que a assembleia era presidida pelo juiz, a quem competia manter o respeito e a ordem nas discussões e deliberações e resolver de pronto as dúvidas suscitadas (art. 101). Além disso, a presença dos síndicos ou liquidatários era obrigatória (art. 101, § $3^{\circ}$ ).

A assembleia podia ser convocada sempre que requerida por credores representando um quarto dos créditos admitidos na falência (art. 100, parágrafo único). As decisões eram tomadas por maioria, calculada sobre a importância dos créditos presentes. Havendo empate, prevalecia a decisão sufragada pela maioria de credores, representando a maioria dos créditos, salvo nas deliberações para as quais a lei exigisse maioria especial (art. 101, § $4^{\circ}$ ).

Interessante notar as previsões legais constantes da 2.024/1908 que visava a organizar e dinamizar as assembleias, bem como a evitar expedientes protelatórios ou abusivos, que marcaram o regime anterior. A Lei n 2.024/1908 previa, por exemplo, que cada credor não poderia falar mais de 10 minutos sobre o assunto em discussão, salvo com o consentimento do juiz, e ainda assim depois de consultada a assembleia (art. 101, § $6^{\circ}$ ). Além disso, o credor que comparecesse depois de iniciados os trabalhos ficava impedido de rediscutir matéria vencida (art. $101, \S 7^{\circ}$ ), sendo certo que a decisão dos presentes obrigava os ausentes (art. 100, $\S 2^{\circ}$ ). E se a resolução das questões afetas à assembleia não pudessem terminar no mesmo dia, o conclave deveria prosseguir nos dias seguintes, admitindo, no máximo, um adiamento por até três dias, cabendo aos credores comparecer independentemente de nova convocação (art. 101, § $8^{\circ}$ ).

Deferia-se aos credores a competência para deliberarem sobre tudo quanto julgassem necessário aos interesses e defesa da massa. Todavia, a validade dessas deliberações encontrava limite na própria lei, sujeitando-se ao controle judicial. Competia ao juiz "vetar" as deliberações contrárias à lei, o que evidencia efetivo controle judicial 
sobre a vontade manifestada pelos credores (art. 102, § $5^{\circ}$ ). Com esse mesmo propósito, admitia-se ainda que o representante do Ministério Público assistisse à assembleia, para que fizesse os requerimentos que reputasse a bem da justiça pública (art. 102, $\S 7^{\circ}$ ). Eis aí algo que se observa muito acentuadamente na evolução do regime concursal brasileiro: a preocupação cada vez mais presente de prevenir e combater as fraudes, especialmente no que diz despeito aos acordos entre credores e devedor.

A Lei n 2.024/1908 vigeu por mais de 20 anos, tendo sido revogada pelo Decreto $\mathrm{n}^{\circ} 5.746$, de 9 de dezembro de 1929, que se propunha a simplificar o processo de concessão da concorda. Contudo, esse decreto pouco alterou a sistemática da concordata preventiva tal como regulada pela Lei $\mathrm{n}^{\circ} 2.024 / 1908$, destacando-se as reduções nos quóruns de aprovação pelos credores, conforme as condições de pagamento propostas pelo devedor (art. 106), e a exigência de garantias correspondentes a pelo menos $50 \%$ dos créditos sujeitos à concordata (art. 149). Quanto à assembleia de credores, manteve-se a mesma sistemática da lei anterior.

\subsection{Decreto-lei $n^{0}$ 7.661, de 1945}

O Decreto-lei n ${ }^{\circ}$ 7.661, de 21 de junho de 1945, promoveu profundas alterações no regime falimentar pátrio, rompendo com a tradição de cometer-se aos credores a decisão sobre a concessão da concordata preventiva ${ }^{18}$, que passou a ficar condicionada apenas ao cumprimento de certos requisitos objetivos (de ordem formal, econômica e ética) previstos na lei (arts. 140 e 156 a 160) ${ }^{19}$.

\footnotetext{
${ }^{18}$ Conforme Trajano de Miranda Valverde: "Desde o Código de 1850 até a lei vigente, exclusive, as seguintes regras se mantinham firmes: a) não pode haver concordata quando o falido ou devedor agiu com culpa ou fraude; b) para a validade da concordata é necessário que a proposta tenha sido apoiada por determinada maioria de credores e de créditos; c) é reconhecido aos dissidentes o direito de se oporem à homologação da concordata; d) a sua eficácia em relação a todos os interessados depende da sentença homologatória do juiz; e) com a homologação forma-se a concordata, que se torna obrigatória para todos os credores, salvo os privilegiados e os que têm garantia real; f) a concordata pode ser rescindida em determinados casos. Essas regras, certamente que nem sempre com a mesma amplitude através da nossa legislação, constituíam as colunas mestras nas quais se apoiava a construção jurídica da concordata, quer preventiva, quer suspensiva da falência. A lei vigente, porém, tomou outro rumo, cancelando a regra sob a letra $\mathrm{b}$, pois que prescinde do consentimento dos credores para a concessão da concordata (Comentários à lei de falências. Rio de Janeiro: Forense, 1948, v. 2, p. 212).

${ }^{19}$ Cf. Rubens ReQuĩ̃o, "se o pedido [do devedor] estiver em termos, corretamente instruído como deve ser, o juiz determinará seja processada a concordata, proferindo despacho ordenatório". Curso de Direito Falimentar...Op. cit., v. 2, p. 78.
} 
O sistema até então vigente deixou de ser utilizado porque se entendeu, na época, que credores premidos por seus interesses particulares não tinham isenção suficiente para decidir se a empresa era recuperável ou não. Além disso, tantas e tão frequentes eram as fraudes que os próprios credores passaram a se desinteressar pela assembleia.

Essa constatação, segundo ressalta MAURo Rodrigues PENTEADO $^{20}$, constou da própria Exposição de Motivos do Decreto-Lei $n^{\circ} 7.661 / 45$, subscrita pelo Ministro Alexandre Marcondes Machado:

"No direito atual, a formação da concordata depende da livre manifestação dos credores, através de quórum de votação, reservandose ao juiz, simplesmente, a homologação do acordo com o devedor. A lei cogita apenas das condições em que a deliberação da maioria obriga a minoria. É peculiar ao instituto, no direito vigente, a imposição da deliberação da maioria sobre a vontade dos dissidentes. O sistema, entretanto, não produz os resultados que seriam de desejar. A preponderância da maioria, nas deliberações coletivas, somente se legitima quando todas as vontades deliberantes se manifestem, tendo em vista o interesse comum que as congregou. Ora, nas concordatas formadas por maioria de votos, os credores deliberam sob a pressão do seu interesse individual, deturpando $o$ interesse coletivo da deliberação e tornando ilegítima a sujeição da minoria. E a verdade é que, na vigência desse sistema, se tem verificado a constância dessa anomalia, através dos entendimentos externos do processo, o que importa na quebra da igualdade de tratamento dos credores, princípio informativo do processo falimentar. Atendendo a esse princípio, consagra a concordata como favor concedido pelo juiz, cuja sentença substitui a manifestação da vontade dos credores na formação do contrato..."

Com a edição do Decreto-lei $n^{0} 7.661 / 45$, a negociação do devedor com seus credores não foi apenas desestimulada, mas passou a ser expressamente vedada: o só fato de o devedor convocar os seus credores para discutir a sua situação de crise podia configurar indício de insolvência e justificar a decretação da falência (art. $2^{\circ}$, III).

Como medidas preventivas à falência, o Decreto-lei $\mathrm{n}^{\mathrm{o}}$ 7.661/45 previa apenas a remissão e a moratória (art. 156). Atendidos os requisitos da lei, o devedor podia liberarse das suas obrigações para com os credores quirografários pagando 50\% dos seus créditos

${ }^{20}$ Comentários à Lei ... Op. cit., p. 64. 
à vista, ou então protelar o pagamento de toda a dívida por até 2 (dois) anos, período em que ficavam suspensas as ações e execuções movidas pelos credores quirografários. Não se dependia mais, portanto, da concordância dos credores.

Em razão disso, no regime do Decreto-lei no 7.661/45, a Assembleia-Geral de Credores foi esvaziada. TRAJANO DE MiRANDA VALVERDE ${ }^{21}$ afirma que ela teria sido "nulificada" pela lei, tão diminutas as funções que lhe foram atribuídas. Em resumo, a atuação da Assembleia-Geral de Credores ficou limitada à falência, conferindo-lhe a prerrogativa de deliberar sobre o modo de realização do ativo.

Conforme previa o art. 122 do Decreto-lei $\mathrm{n}^{\mathrm{o}}$ 7.661/45, credores que representassem mais de um quarto do passivo habilitado poderiam requerer ao juiz a convocação de assembleia para deliberar sobre a forma de realização do ativo. A convocação dos credores era feita por edital, com pelo menos oito dias de antecedência. A assembleia continuava sendo presidida pelo juiz, que tinha o poder de vetar as deliberações contrárias à lei. As deliberações eram tomadas por maioria calculada sobre a importância dos créditos dos credores presentes (exceto para a aprovação de forma alternativa de liquidação, que dependia do voto favorável de credores representantes de dois terços dos créditos $^{22}$ ). No caso de empate, prevalecia a decisão do grupo que reunir maior número de credores.

$\mathrm{Na}$ prática, porém, raríssimos foram os casos em que realmente houve a realização da Assembleia-Geral de Credores ${ }^{23}$.

Como a liquidação dos ativos era preterida para depois de um longo processo de verificação dos créditos e da conclusão do inquérito judicial, os bens que compunham a massa acabavam perecendo ou simplesmente se desvalorizavam, em razão da obsolescência. Assim, o que sobrava ao final geralmente não estimulava os credores a convocar assembleia apenas para determinar o modo de realização do ativo (que já tinha previsão em lei):

\footnotetext{
${ }^{21}$ Comentários à Lei de Falências. Rio de Janeiro: Forense, 2001. v. 2, p. 184.

${ }^{22}$ Cf. art. 123 do Decreto-lei $n^{\circ} 7.661 / 45$.

${ }^{23}$ Cf. JoÃo Bosco CASCARdo de GouvÊA. Recuperação e Falência. Rio de Janeiro: Forense, 2009, p. 70.
} 
"No Brasil, a antiga Lei de Falências (Dec.-Lei no 7.661/45) chegou a prever, nos arts. 122 e 123, a possibilidade de os credores se reunirem em assembléia para deliberar quanto à melhor forma de liquidação do ativo do devedor falido. A utilização do referido dispositivo foi, contudo, marcada pelo insucesso, notadamente pela falta de interesse dos credores que, na maioria das vezes, diante da morosidade procedimental que terminava por depreciar todo o ativo do devedor falido, não viam qualquer possibilidade de recuperar seus créditos, nem tampouco qualquer benefício da instalação da Assembléia de Credores, a qual, usualmente, significa apenas mais um sacrifício para tais credores. Desse modo, embora já estivesse expressamente disciplinado no Dec.-Lei $\mathrm{n}^{\circ} 7.661 / 45$, o instituto era pouco ou raramente utilizado pelos credores." (PAULO CÉSAR Aragão e LAURA BUMACHAR $^{24}$ ).

De sorte que a alienação acabava mesmo ficando a cargo do síndico e do juiz, que procediam segundo a lei.

\section{Considerações gerais sobre a Lei $n^{0}$ 11.101/2005}

\subsection{A função social da empresa e a sua preservação}

Para a grande maioria dos doutrinadores - entre eles, FÁBIO KONDER COMPARATO -, a função social da empresa deriva da função social da propriedade ${ }^{25}$, assegurada constitucionalmente como direito fundamental e princípio da ordem econômica (arts. $5^{\circ}$, XXIII, e 170, III, da Constituição Federal de 1988, respectivamente).

Em síntese, liga-se à ideia de que os bens de produção, “quando ... são incorporados a uma exploração empresarial", destinam-se "à realização dos interesses coletivos", consistindo "poder-dever do titular do controle" dirigir a empresa de modo a promover esses interesses ${ }^{26}$.

\footnotetext{
24 “A Assembléia Geral de Credores na Lei de Recuperação e Falências". In: SANTOS, Paulo Penalva (coord.). A nova lei de falências e de recuperação de empresas. Rio de Janeiro: Forense, 2007, p. 111.

25 “Estado, empresa e função social”. Revista dos Tribunais, n. 732, p. 38.

${ }^{26}$ Cf. FÁBio Konder Comparato. "Função social da propriedade dos bens de produção". In: Estudos $e$ Pareceres. São Paulo: Saraiva, 1990, p. 34
} 
Quer isso dizer que a empresa deve empregar sua organização de modo a produzir e circular riquezas, gerando empregos, impostos etc, em respeito à legislação vigente. É essa a função social da empresa ${ }^{27}$, que não se confunde com a "responsabilidade social" de prover "bem-estar e justiça social", que é dever do Estado assegurar ${ }^{28}$.

Desde 1976, encontra-se positivada no ordenamento jurídico pátrio, insculpida no art. 116 da Lei das Sociedades por Ações (Lei n. 7.404/76): “o acionista controlador deve usar o poder com o fim de fazer a companhia realizar o seu objeto e cumprir sua função social, e tem deveres e responsabilidades para com os demais acionistas da empresa, os que nela trabalham e para com a comunidade em que atua, cujos direitos $e$ interesses deve lealmente respeitar e atender".

No âmbito do direito falimentar, embora a legislação pátria desde 1850 previsse instrumentos para evitar a quebra (conforme visto acima), não se pode afirmar que visassem propriamente à preservação da empresa ou à sua função social (ainda que, em certos casos, pudessem contribuir para a consecução desses objetivos).

$\mathrm{Na}$ verdade, conforme a tônica da lei vigente, esses instrumentos ora serviam para facilitar a liquidação do ativo e o pagamento dos credores, ora consistiam em verdadeira "liberalidade", em "privilégio concedido ao devedor", inclusive contra o interesse geral (como ocorria, p. ex., com o Decreto-lei $\left.n^{\circ} 7.661 / 45\right)^{29}$.

Daí a ineficiência do sistema falimentar brasileiro, acentuada a partir da década de 1970. A rigidez do Decreto-lei no 7.661/45 impedia empresas viáveis de superar suas dificuldades econômico-financeiras, enquanto garantia a continuidade de outras tantas que, fadadas ao fracasso, exigiam pronta liquidação ${ }^{30}$.

27 Sobre o conceito de função social da empresa, confira-se também EDUARDO TOMASEVICIUS FILHO ("Função social da empresa". Revista dos Tribunais, São Paulo, n. 810, p. 33-50) e MAURícIO MOREIRA MENDONÇA DE MENEZES ("Função sócio-econômica da empresa em recuperação". Revista Semestral de Direito Empresarial, n. 1, p. 49-86).

${ }^{28}$ Confira-se, a esse respeito, Guilherme Calmon Nogueira da Gama e Bruno Paiva Bartholo. "Função social da empresa" (In: Delgado, Mário Luiz; Alves, Jones Figueiredo. Novo Código Civil: Questões controvertidas: direito de empresa. São Paulo: Método, 2010, p. 407).

29 É nesse sentido a lição FÁBIO KONDER COMPARATO ao descrever o "dualismo pendular" do direito falimentar brasileiro. Aspectos jurídicos...Op. cit., p. 101.

${ }^{30}$ Cf. RiCARDo TEPEDINO. “A recuperação da empresa em crise diante do Decreto-lei 7.661/1945”. RDM, n. 128 , p. 165. 
Nessa mesma época, despontavam no país empresas que, por sua importância, simplesmente não podiam quebrar. Casos como o da falência da "Sanderson" e a do "Frigorífico Tião Maia”31 - que demandaram a intervenção do Estado para garantir-lhes a preservação - aceleraram as discussões sobre a necessidade de profunda reforma legislativa, que só viria décadas mais tarde.

Após longa tramitação no Congresso Nacional, foi finalmente editada a Lei $n^{\circ}$ 11.101/2005 (LRF), que promoveu as esperadas alterações nos institutos falimentares, erigindo a preservação da empresa ao nível de princípio informador do direito concursal brasileiro $^{32}$. O art. 47 da LRF, o primeiro do capítulo destinado especificamente à "recuperação judicial”, dá a tônica da nova legislação:

“a recuperação judicial tem por objetivo viabilizar a superação da situação de crise econômico-financeira do devedor, a fim de permitir a manutenção da fonte produtora, do emprego dos trabalhadores e dos interesses dos credores, promovendo, assim, a preservação da empresa, sua função social e o estímulo à atividade econômica."

Segundo MAURo Rodrigues Penteado, o art. 47 da LRF encerra "regra basilar que deve orientar não apenas a recuperação judicial, mas também os processos de homologação da recuperação extrajudicial, e mesmo a decretação da falência”33.

Contudo, de forma até um pouco contraditória, a LRF não atribui ao juiz, mas aos credores, a decisão sobre a viabilidade ou inviabilidade da empresa que pede a recuperação. Nesse sentido, dispõe o art. 58 da LRF que o juiz concederá a recuperação judicial cujo plano não tenha sofrido objeção dos credores, ou tenha sido aprovado na assembleia geral de que trata o art. 45 da mesma lei, por maioria de votos de todas as classes de credores.

\footnotetext{
${ }^{31}$ cf. Paulo SAlvador Frontini. "O caso da falência da Sanderson e as atuais tendências do direito falimentar". RDM, n. 15-16, p. 247

${ }^{32}$ Segundo RACHEL SZTAJN, "ao se referir a estímulo à atividade econômica, está implícito o reconhecimento de que a empresa é uma das fontes geradoras de bem-estar social e que, na cadeia produtiva, o desaparecimento de qualquer dos elos pode afetar a oferta de bens e serviços, assim como a de empregos, por conta do efeito multiplicador na economia" (In: SouZA Junior, Francisco Satiro; PITOMBo, Antônio Sérgio de Moraes (Coords.). Comentários à Lei de Recuperação de Empresas e Falência. São Paulo: RT, 2005, p. 221).

${ }^{33}$ In: SOUZA JUNIOR, Francisco Satiro; PITOMBo, Antônio Sérgio de Moraes. Op. cit., p. 103.
} 
Muito curiosamente, esse sistema (de relegar aos credores o poder de evitar falência do comerciante) vigorou no País até meados do século XX, mas acabou sendo abandonado pelo Decreto-lei $n^{\circ} 7.661 / 45$, justamente porque a experiência mostrara que os credores, premidos por seus interesses particulares, careciam de isenção para decidir se a empresa era recuperável ou não. Na "Exposição de Motivos" do referido decreto, subscrita pelo Ministro Alexandre Marcondes Machado, lê-se justamente o seguinte:

"É peculiar ao instituto, no direito vigente, a imposição da deliberação da maioria sobre a vontade dos dissidentes. O sistema, entretanto, não produz os resultados que seriam de desejar. A preponderância da maioria, nas deliberações coletivas, somente se legitima quando todas as vontades deliberantes se manifestem, tendo em vista o interesse comum que as congregou. Ora, nas concordatas formadas por maioria de votos, os credores deliberam sob a pressão do seu interesse individual, deturpando o interesse coletivo da deliberação e tornando ilegítima a sujeição da minoria".

Mesmo hoje, há quem enxergue certa antinomia entre esse modelo (de cometer aos credores a decisão sobre a concessão da recuperação) e o princípio da preservação da empresa, conforme relata EDUARDO SECCHI MUNHOZ ${ }^{34}$ :

"de um lado, posicionam-se aqueles que crêem no papel supremo do juiz como guardião do interesse público e que vêem com enorme desconfiança soluções baseadas na participação dos credores, as quais somente poderiam levar ao atendimento de interesses puramente privados e egoísticos. De outro, cerram fileiras os que não acreditam na possibilidade de o Estado-juiz encaminhar soluções economicamente eficientes, defendendo não haver ninguém melhor que os próprios credores, afetados pela crise da empresa, para definir os rumos a serem tomados".

Essa não seria, aliás, a única incoerência na Lei $n^{\circ}$ 11.101/2005. Em contundente artigo, MANOEL JUSTINO BEZERRA FILHO ${ }^{35}$ critica veementemente a previsão constante do art. 48, $\S 3^{\circ}$, que exclui dos efeitos da recuperação judicial os créditos decorrentes de arrendamento mercantil e negócio fiduciário, entre outros. Para o autor, tal

\footnotetext{
34 "Anotações sobre os limites do poder jurisdicional na apreciação do plano de recuperação judicial". $R D B M C$, n. 36, p. 185.

35 "Exame crítico da lei de falências: recuperação de empresa ou recuperação do crédito bancário". $R T, \mathrm{n}$. 138, p. 128-138.
} 
disposição serve exclusivamente à recuperação do crédito bancário, distanciando-se do princípio da preservação da empresa.

De qualquer forma, é preciso ressaltar que a preservação da empresa devedora, por si só, não atenta contra o interesse dos credores, podendo muito bem beneficiá-los.

É que, ao longo da história, a falência do devedor sempre significou prejuízo certo e irreparável para os credores, notadamente para os não favorecidos por garantia real. Com a só notícia da quebra, os credores sem preferência (e, por vezes, até os preferenciais, dependendo do montante das dívidas trabalhistas e fiscais) já contabilizavam o prejuízo, sabendo que muito dificilmente receberiam o que lhes era devido.

Isso se dava, fundamentalmente, por duas razões.

Em primeiro lugar, porque o patrimônio do devedor, sobretudo em situação de crise, muito dificilmente respondia pelo cumprimento de todas as suas obrigações. E a falência só fazia piorar essa situação, pois ordinariamente implicava a descontinuidade da atividade e a cessação do faturamento ${ }^{36}$.

Em segundo lugar, porque o processo liquidatório da falência nunca foi eficiente para preservar o valor dos bens que compunham a massa. Os custos envolvidos, as fraudes cometidas, os embaraços criados pelo próprio devedor, a morosidade e a falta de aparelhamento do Judiciário, entre outras coisas, contribuíam decisivamente para o perecimento dos bens capazes de satisfazer os credores.

Como se não bastasse, essa situação era ainda agravada pelo modo como conduzida a alienação dos bens da massa. Salvo raras exceções, o que se fazia era retalhar a empresa e vender de forma fracionada os bens que lhe compunham o ativo. Desse modo, só eram aproveitados aqueles bens que, individualmente, possuíam valor considerável, dado que todos os demais, uma vez desintegrados da universalidade que compunha o estabelecimento, perdiam significativamente a sua relevância econômica. Em alguns casos,

\footnotetext{
${ }^{36}$ Questão pormenorizadamente enfrentada por NELSON ABRÃo na obra A continuidade do negócio na falência. São Paulo: Leud, 1975
} 
o custo da guarda e preservação desses bens chegava a ser maior do que o produto da sua venda.

É nesse contexto que a preservação da empresa atende aos interesses dos credores, seja no processo de recuperação, seja na falência.

Evitando-se a liquidação mediante acordo (judicial ou extrajudicial) que possibilite ao devedor reorganizar a sua atividade, poderá ele acumular novas receitas para satisfazer créditos que possivelmente não seriam pagos apenas com o rateio do seu patrimônio.

Mesmo no processo falimentar, ao estimular-se o aproveitamento daquela universalidade constituída pelo empresário, com medidas como as que privilegiam a alienação dos estabelecimentos em bloco, com isenção de sucessão para os adquirentes (LRF, arts. 140 e 141, II), são propiciados à massa recursos bem mais significativos do que os obtidos com a alienação fracionada dos ativos do devedor.

Em ambos os casos, a continuação da atividade da empresa, se viável, favorece os credores.

\subsection{Mecanismos de preservação da empresa}

A Lei $n^{\circ} 11.101 / 2005$ disciplina uma série de mecanismos que se destinam a concretizar o princípio da preservação da empresa. Nos estreitos limites deste trabalho, serão abordados os principais deles, com especial atenção àqueles pertinentes ao processo da recuperação judicial.

\subsubsection{A preservação da empresa na recuperação judicial}

Entre os principais mecanismos de preservação da empresa no processo de recuperação judicial, valem ser citados os seguintes: 


\subsubsection{Suspensão das ações e execuções}

Por força do art. $6^{\circ}$, caput e $\S 4^{\circ}$, da LRF, o deferimento do processamento da recuperação judicial faz suspender, pelo prazo improrrogável de 180 (cento e oitenta) dias, a prescrição e o curso de todas as ações e execuções contra o devedor ${ }^{37}$, salvo as ações que demandarem quantia ilíquida, as ações de natureza trabalhista até a apuração do respectivo crédito, as execuções fiscais e as ações relativas aos créditos excetuados na forma dos $\S \S$ $3^{\circ}$ e $4^{\circ}$ do art. 49 (LRF, art. $6^{\circ}, \S \S 1^{\circ}, 2^{\circ}$ e $7^{\circ}$ e 52, III).

Esse prazo, conhecido como automatic stay ${ }^{38}$, concede ao devedor um "fôlego" inicial para organizar a sua atividade e discutir o plano de recuperação com os credores em posição um pouco mais confortável.

Critica-se, porém, a inexistência de mecanismo que confira ao juiz a possibilidade de, diante do caso concreto, conceder a prorrogação desse prazo ${ }^{39}$, como forma de evitar o comprometimento da negociação entre credores e devedor ${ }^{40}$. Tanto é assim que, não obstante a regra legal, registram-se na jurisprudência casos de dilação deferida pelo juiz, no tocante a certas obrigações do devedor, com fundamento no princípio da função social da empresa:

\footnotetext{
${ }^{37}$ Com algumas variações, esse mesmo instrumento é previsto em várias outras legislações, como, por exemplo, na reorganization do direito norte-americano (o chamado automatic stay, ou stay period, previsto no Bankruptcy Code, § 362). Na França, essa suspensão preventiva das ações e execuções contra o devedor ocorre no procedimento da sauvegard (Code de Commerce, art. L622-21). No Reino Unido, acha-se na administration (Insolvency Act de 1986, Schedule B1).

38 “A order for relief produz, como efeito imediato, a paralisação automática de toda providência, judicial ou extrajudicial, que estiver sendo tomada por um credor e para receber seu crédito. Dá-se ao fenômeno, que não se restringe aos procedimentos em curso, vedando também a instauração de novos (desde que se refiram a créditos anteriores), o nome de automatic stay". (PAULO F. C. SALLES DE TOLEDO. A empresa em crise no direito francês e americano. Dissertação de Mestrado, São Paulo: Faculdade de Direito da USP, 1987, p. 22).

${ }^{39}$ Diferentemente do que ocorre nos Estados Unidos, em que não há termo final para a suspensão das ações e execuções, que se estende até final do processo de recuperação, isto é, até a aprovação ou rejeição do plano de recuperação (cf. EdUARDo SECCHI MunHOZ. In: SOUZA JUNIOR, Francisco Satiro; PITOMBO, Antônio Sérgio de Moraes (Coords.). Comentários à Lei de Recuperação de Empresas e Falências. São Paulo: Revista dos Tribunais, 2005, p. 272).

${ }^{40}$ EdUARDO SECCHI MUNHOZ pondera que o legislador brasileiro, ainda que estabelecendo critérios rígidos e objetivos, deveria ter flexibilizado o prazo de suspensão das ações e execuções contra o devedor: "Assim, poderia a lei estabelecer requisitos, tão precisos quanto objetivos como possível, os quais, uma vez presentes em cada caso, poderiam levar o juiz a levantar a suspensão em relação a determinados credores, ou mesmo a prorrogar o prazo de 180 dias. Tais requisitos previstos na lei limitariam o poder de interferência do juiz sobre o processo de negociação, mas ao mesmo tempo introduziriam maior flexibilidade ao modelo" (Idem, p. 273).
} 
"Tratando-se de bem essencial à atividade da empresa recuperanda, a busca e apreensão determinada após a concessão da recuperação judicial, mesmo esgotado o prazo de 180 (cento e oitenta) dias, denominado "blindagem", não poderá ser efetivada, sob pena de inviabilizar o sistema de recuperação da empresa e, por conseqüência, negar vigência ao princípio que lhe é norteador." (Tribunal de Justiça de Minas Gerais. 5 ${ }^{a}$ Câmara Cível. Agravo de Instrumento $\mathrm{n}^{\mathbf{0}}$ 1.0079.07.348871-4/002. Rel. Des. Dorival Guimarães Pereira. j. 29.5.2008).

\subsubsection{Os meios de recuperação}

No regime vigente, ficam sujeitos à recuperação, salvo algumas poucas (mas significativas) exceções ${ }^{41}$, todos os credores existentes à época do pedido, inclusive os privilegiados ou com garantia real. Não apenas permite-se a negociação coletiva ou individual entre o devedor e os seus credores, como ela é amplamente estimulada.

Como a concessão da recuperação depende do consentimento dos credores, o devedor precisa elaborar o plano de recuperação atentando para os interesses deles, de modo a viabilizar o soerguimento da empresa.

Em conformidade com a atual realidade econômica e negocial, a LRF admite várias medidas para promover-se a recuperação da empresa ${ }^{42}$ (além da remissão e da moratória, tradicionalmente contempladas pelo direito pátrio), as quais se encontram relacionadas no art. 50 da $\mathrm{LRF}^{43}$.

${ }^{41}$ Fica excluído da recuperação o "credor titular da posição de proprietário fiduciário de bens móveis ou
imóveis, de arrendador mercantil, de proprietário ou promitente vendedor de imóvel cujos respectivos
contratos contenham cláusula de irrevogabilidade ou irretratabilidade, inclusive em incorporaçães
imobiliárias, ou de proprietário em contrato de venda com reserva de domínio" (LRF, art. 49, § $3^{\circ}$ ). Da
mesma forma, não se sujeita aos efeitos da recuperação "a importância entregue ao devedor, em moeda
nacional decorrente de adiantamento de contrato de câmbio para exportação" (LRF, arts. 49 , § $4^{\circ}$ e 86, II).
${ }^{42}$ Essa vastidão de meios de recuperação é especialmente contemplada pela reorganization norte-americana,
achando-se ainda nos sistemas de vários outros países, como Portugal, Espanha, Itália e Alemanha, entre
outros.

${ }^{43}$ Art. 50. Constituem meios de recuperação judicial, observada a legislação pertinente a cada caso, dentre outros: I - concessão de prazos e condições especiais para pagamento das obrigações vencidas ou vincendas; II - cisão, incorporação, fusão ou transformação de sociedade, constituição de subsidiária integral, ou cessão de cotas ou ações, respeitados os direitos dos sócios, nos termos da legislação vigente; III - alteração do 
Conforme a doutrina ${ }^{44}$, as medidas previstas no art. 50 da LRF podem ser adotadas tanto individualmente como de forma combinada, sendo ainda possível adotaremse outras não previstas nesse dispositivo, meramente exemplificativo. Com isso, privilegiase a criatividade do empresário ao mesmo tempo em que se reconhece a impossibilidade de o legislador prever todas as formas capazes de recuperar as mais diversas empresas, em razão das mais diversas crises.

O plano, no entanto, não poderá prever prazo: (i) superior a 1 (um) ano para pagamento dos créditos derivados da legislação do trabalho ou decorrentes de acidentes de trabalho vencidos até a data do pedido de recuperação judicial; nem (ii) superior a 30 (trinta) dias para o pagamento, até o limite de 5 (cinco) salários-mínimos por trabalhador, dos créditos de natureza estritamente salarial vencidos nos 3 (três) meses anteriores ao pedido de recuperação judicial (art. 54).

Nos termos do artigo 53 da LRF, o devedor deve apresentar o plano de recuperação em juízo no prazo improrrogável de 60 (sessenta) dias, contado da publicação da decisão que deferir o processamento da recuperação judicial, sob pena de ser-lhe decretada a falência.

A limitação desse prazo vem sendo objeto de várias críticas, pois não permite ao devedor negociar adequadamente com seus credores as condições do plano de

\footnotetext{
controle societário; IV - substituição total ou parcial dos administradores do devedor ou modificação de seus órgãos administrativos; V - concessão aos credores de direito de eleição em separado de administradores e de poder de veto em relação às matérias que o plano especificar; VI - aumento de capital social; VII - trespasse ou arrendamento de estabelecimento, inclusive à sociedade constituída pelos próprios empregados; VIII redução salarial, compensação de horários e redução da jornada, mediante acordo ou convenção coletiva; IX - dação em pagamento ou novação de dívidas do passivo, com ou sem constituição de garantia própria ou de terceiro; X - constituição de sociedade de credores; XI - venda parcial dos bens; XII - equalização de encargos financeiros relativos a débitos de qualquer natureza, tendo como termo inicial a data da distribuição do pedido de recuperação judicial, aplicando-se inclusive aos contratos de crédito rural, sem prejuízo do disposto em legislação específica; XIII - usufruto da empresa; XIV - administração compartilhada; XV emissão de valores mobiliários; XVI - constituição de sociedade de propósito específico para adjudicar, em pagamento dos créditos, os ativos do devedor.

${ }^{44}$ Entre muitos outros, FÁBIo UlhoA CoElho (Comentários à Nova Lei de Falências e de Recuperação de Empresas. São Paulo: Saraiva, 2005. p. 134)
} 
recuperação ${ }^{45}$, por vezes extremamente $\operatorname{complexas}^{46}$, conforme salienta MÁRCIO GUIMARÃES ${ }^{47}$ :

"A norma brasileira optou por fixar prazo para apresentação do plano;
medida que não se afigura apropriada pois, dependendo da empresa
que se pretende recuperar, 60 dias poderão se afigurar como diminutos
ou demasiados - cada atividade, dependendo da sua estrutura
econômica e financeira, tem uma característica própria que demanda
prazo diferenciado. Diante de tal realidade sobre a opção legislativa
pela disposição legal do prazo, o plano de recuperação será elaborado,
na maioria das vezes, muito antes do ingresso em juízo, utilizando-se
o prazo legal de 60 dias apenas para ajustes finais."

\subsubsection{A aprovação do plano - cram down}

O art. 58 da LRF prevê que o juiz concederá a recuperação judicial cujo plano não tenha sofrido objeção dos credores, ou tenha sido aprovado na assembléia geral de que trata o art. 45 da mesma lei, por maioria de votos de todas as classes de credores.

Entretanto, mesmo não se logrando obter a aprovação das três classes de credores, dispõe o art. $58, \S \S 1^{\circ}$ e $2^{\circ}$, da LRF que o juiz poderá conceder a recuperação judicial desde que, na assembleia, (i) as demais classes tenham aprovado o plano, (ii) a soma dos créditos daqueles que votaram favoravelmente ao plano represente mais da metade do valor de todos os créditos presentes à assembleia, independentemente de classe; (iii) na classe que o houver rejeitado, mais de 1/3 (um terço) dos credores tenham votado

\footnotetext{
45 A esse respeito, anota RACHEL SZTAJN: "Pior é que o prazo de 60 dias não pode ser prorrogado e a não apresentação do plano dentro desse lapso leva, ope legis, à decretação da falência. Como o plano não pode ser sugestivo das medidas que serão adotadas, conforme determina o inc. I do art. 53, devendo expor, de maneira pormenorizada, detalhada, a quais meios se pretende recorrer, será que 60 dias é prazo suficiente? Quando, por exemplo, se propuser a cisão e incorporação da parcela cindida do patrimônio social em outra sociedade, seria necessário indicar não apenas esse procedimento, mas também a sociedade receptora da parcela cindida? E quando se tratar da alienação de bens ou do estabelecimento, interessa saber o valor que se imagina receber? O que fazer quando não houver interessados? A segunda melhor opção (second best) deve estar contemplada?" (In: SOUZA Junior, Francisco Satiro; PITOMBo, Antônio Sérgio de Moraes. Comentários...Op. cit., p. 265).

${ }^{46}$ Nos Estados Unidos, por exemplo, o prazo para o devedor apresentar o plano de recuperação é de 120 dias, podendo ser estendido até 18 meses a critério do juiz (Bankruptcy Code, § 1.121).

${ }^{47}$ In: Comentários à Nova Lei de Falência e Recuperação de Empresas. CORRÊA-LIMA, Osmar Brina; LIMA, Sérgio Mourão Corrêa (coords.). Rio de Janeiro: Forense, 2009, p. 382-383.
} 
favoravelmente; e (iv) o plano não implique tratamento diferenciado entre os credores da classe que o houver rejeitado.

A essa possibilidade de o juiz impor o plano de recuperação a determinada classe de credores dissidentes, dá-se o nome de "cram down", instituto que se acha mais bem explicado adiante.

\subsubsection{Financiamento da recuperação}

Entre os pontos mais relevantes para o soerguimento da empresa está, sem dúvida, o seu financiamento durante o processo de recuperação. A LRF contém alguns dispositivos que contemplam essa necessidade:

O art. 60, 'caput' e parágrafo único, da LRF prevê que a alienação judicial de filiais ou de unidades produtivas isoladas do devedor, em cumprimento ao plano de recuperação, não torna o adquirente sucessor do devedor nas obrigações deste, inclusive as de natureza tributária (e trabalhista).

Ao mesmo tempo em que financia a recuperação da empresa, esse instrumento objetiva estimular terceiros a dar continuidade às atividades da empresa que não mais podem ser mantidas pelo devedor.

Os arts. 67 e 84 da LRF, por outro lado, dispõem que os créditos decorrentes de obrigações contraídas pelo devedor durante a recuperação judicial, inclusive aqueles relativos a despesas com fornecedores de bens ou serviços e contratos de mútuo, serão considerados extraconcursais ${ }^{48}$, em caso de decretação de falência, e pagos prioritariamente aos demais créditos previstos no art. 83 da LRF.

Tal previsão tem intuito principal de garantir o fornecimento ao devedor daqueles insumos indispensáveis à continuação da sua atividade, ordinariamente interrompido com o início de processo concursal.

\footnotetext{
48 Instrumento semelhante é observado, por exemplo, no direito francês, relativamente aos vários procedimentos preventivos/recuperatórios lá previstos (Code de Commerce, art. L611-11).
} 
Finalmente, o art. 68 da LRF dispõe que as Fazendas Públicas e o Instituto Nacional do Seguro Social - INSS poderão deferir, nos termos da legislação específica, parcelamento de seus créditos, em sede de recuperação judicial, de acordo com os parâmetros estabelecidos no Código Tributário Nacional.

Ainda não existe, contudo, legislação que cuide especificamente do parcelamento de débitos fiscais para empresas em processo de recuperação judicial, o que vem sendo objeto de inúmeras críticas. A tal ponto que a jurisprudência tem feito "vista grossa" para o disposto no art. 57 da LRF, que exige a apresentação da certidão negativa de débitos tributários para a concessão da recuperação judicial ${ }^{49}$.

\subsubsection{Afastamento do devedor e dos seus administradores (LRF, arts. 64 e 65)}

$\mathrm{O}$ art. 64 da LRF estabelece que, durante o procedimento de recuperação judicial, o devedor ou seus administradores serão mantidos na condução da atividade empresarial, sob fiscalização do Comitê (se houver) e do administrador judicial. Conduto, o mesmo artigo admite que os administradores ou o próprio devedor sejam afastados da condução dos negócios se qualquer deles:

(i) for condenado em sentença penal transitada em julgado por crime cometido em recuperação judicial ou falência anteriores ou por crime contra o patrimônio, a economia popular ou a ordem econômica previstos na legislação vigente;

(ii) tiver cometido crime falimentar, se assim indicarem indícios veementes;

(iii) tiver agido com dolo, simulação ou fraude contra os interesses de seus credores;

(iv) houver efetuado gastos pessoais manifestamente excessivos em relação a sua situação patrimonial, ou despesas injustificáveis por sua natureza ou vulto, em relação ao capital ou gênero do negócio, ao movimento das operações e a outras circunstâncias análogas;

49 TJMG, AI n ${ }^{\text {o } 1.0079 .06 .288873-4 / 01, ~ r e l . ~ D e s . ~ D o r i v a l ~ G u i m a r a ̃ e s ~ P e r e i r a, ~ j . ~ 29.5 .2008 ; ~ T J S P, ~ A I ~} n^{\circ}$ 507.990-4/8-00, rel. Des. Romeu Ricupero, j. 1.8.2007; TJRJ, AI nº 0019759-96.2010.8.19.0000, rel. Des. Teresa de Andrade Castro Neves, j. 11.8.2010; cf. CRISTIANO IMHOF. Lei de recuperação de empresas e falências. 2 ed. Balneário Camboriu: Publicações Online, 2012, p. 298-300). 
(v) descapitalizar injustificadamente a empresa ou realizado operações prejudiciais ao seu funcionamento regular;

(vi) simular ou omitir créditos ao apresentar a relação de que trata o inciso III do caput do art. 51 da LRF, sem relevante razão de direito ou amparo de decisão judicial;

(vii) negar-se a prestar informações solicitadas pelo administrador judicial ou pelos demais membros do Comitê; ou ainda

(viii) tiver seu afastamento previsto no plano de recuperação judicial.

O administrador destituído será substituído na forma prevista no contrato ou estatuto social do devedor (LRF, art. 64, p. u.). Já no caso de afastamento do próprio devedor, o juiz nomeará um gestor judicial ${ }^{50}$ (outra inovação da LRF), a ser indicado pela Assembleia-Geral de Credores. Esse gestor assumirá a administração das atividades do devedor, sendo que, enquanto não for nomeado, suas funções serão provisoriamente exercidas pelo administrador judicial (LRF, art. 65 da LRF).

Vê-se aí exemplo de como a LRF faz, acertadamente, a separação da figura empresa da do seu titular: afasta-se este (titular) para preservar aquela (empresa), dada a relevante função social que exerce.

\footnotetext{
${ }^{50}$ A figura do gestor judicial tem flagrante inspiração case trustee do direito norte-americano, nomeado no processo da reorganization, a pedido de qualquer interessado, mas desde que antes da confirmação do plano (Bankruptcy Code, $§ 1.104)$. A possibilidade de afastar-se o devedor ou seus administradores da condução da empresa também é prevista na França, no procedimento de redressement judiciaire (Code de Commerce, art. L631-12). Na Inglaterra, com certas peculiaridades, encontra-se no processo de administration (Insolvency Act de 1986, Schedule B1). Na Espanha, caso se cuide de concurso necessário, instaurado a pedido dos credores ou de outros interessados, o afastamento será obrigatório, passando-se a direção da empresa aos administradores concursais; cuidando-se, todavia, de concurso voluntário, instaurado a pedido do próprio devedor, ele e seus administradores permanecerão conduzindo a empresa, salvo se o juiz determinar a suspensão dos seus direitos (Lei Concursal de 2003, art. 40). Curiosamente, o direito alemão, na contramão da maioria das principais economias mundiais, não adota o sistema do debtor in possession: o processo de insolvência implica desde logo a perda do direito de administração e disposição dos bens da empresa por parte do devedor e de seus administradores (Insolvenzordnung, § 80).
} 


\subsubsection{A preservação da empresa na falência}

Mas não é só no processo de recuperação que se privilegia a preservação da empresa. Esta também é perseguida no procedimento falimentar, conforme declarado pelo art. 75 da $\operatorname{LRF}^{51}$ e constatado especialmente nos seguintes dispositivos:

(i) art. 99, XI, que autoriza o juiz a determinar, na sentença de quebra, a continuação provisória das atividades do falido com o administrador judicial;

(ii) art. 139, que prevê a alienação antecipada dos ativos, a fim de evitar-se a sua desvalorização;

(iii) art. 140, que privilegia a realização do ativo mediante a alienação de toda a empresa, com a venda dos seus estabelecimentos em bloco, ou mediante a alienação de suas filiais ou unidades produtivas isoladas; e

(iv) art. 141, II, que isenta o comprador desse ativo de responsabilidade pelas dívidas do falido, inclusive as de natureza tributária e trabalhista.

Como já se disse, a preservação da empresa, mesmo na falência, além de promover a sua função social, contribui para a maximização dos ativos do devedor ${ }^{52}$, atendendo também aos interesses dos credores.

\footnotetext{
${ }^{51}$ Art. 75. A falência, ao promover o afastamento do devedor de suas atividades, visa a preservar e otimizar a utilização produtiva dos bens, ativos e recursos produtivos, inclusive os intangíveis, da empresa.

52 Este, aliás, é um dos principles and guide lines for effective insolvency and creditor rights system publicados em 2001 pelo World Bank.
} 


\section{CAPÍTULO II - OS CREDORES}




\section{CAPÍTULO II - OS CREDORES}

\section{Os credores e seus interesses}

Com o advento da Lei $\mathrm{n}^{\circ}$ 11.101/2005, o processo de recuperação judicial e da falência, excetuada a recuperação especial para as pequenas e microempresas, passou a girar em torno da Assembleia-Geral de Credores, à qual foram atribuídas competências para decidir acerca do futuro da empresa em crise.

Pode-se dizer que, na novel legislação, os interesses daqueles direta e indiretamente afetados pela crise da empresa gravitam em torno da Assembleia-Geral de Credores, centro de decisão das matérias afetas à continuidade do negócio, ao pagamento das dívidas, ao emprego dos trabalhadores, à liquidação dos ativos etc.

A Assembleia-Geral de Credores compõe-se de diversas classes de credores (que não se limitam àquelas arbitrariamente definidas pela lei), cujos interesses se alinham ou se contrapõem dependendo da direção do vento ou, não raramente, de acordos que extrapolam as questões pertinentes a determinada empresa em crise.

Questiona-se a legitimidade de qualquer decisão tomada pela assembleia, ainda que por maioria, pois os interesses que determinam a deliberação não são, em regra, os da empresa em recuperação ou falida, mas os próprios interesses individuais dos credores. E é até natural que assim seja, pois a reunião dos credores não surge da vontade de cooperação mútua (como se dá, por exemplo, numa sociedade), mas é imposto por uma situação de crise.

Nessas condições, saber a composição do quadro de credores, do ponto de vista econômico, passa a ser determinante para compreender suas deliberações, isto é, para saber como as forças e interesses individuais direcionam esta ou aquela decisão, e como isso afeta a empresa em crise e os valores protegidos pela lei (a preservação da empresa, dos empregos e da atividade econômica). 
Não é pretensão deste trabalho incursionar pela chamada "análise econômica do direito", mas tão somente chamar atenção para importância do ambiente em que são tomadas as deliberações e dos interesses particulares que as determinam, de modo a tornar todo o processo mais previsível, com redução dos custos de transação, o que, aliás, é um dos objetivos da legislação falimentar:

"Sob o ponto de vista econômico, a legislação falimentar tem como objetivo criar condições para que situações de insolvência tenham soluções previsíveis, rápidas e transparentes, de forma que os ativos sejam preservados e continuem cumprindo sua função social, gerando produto, emprego e renda." (STEFANIA EUGENIA BARICHELLO ${ }^{53}$ )

Dito de outro modo, não se pode ignorar que, no mundo real, a preservação da empresa em crise e sua função social, conquanto princípios informadores da lei, não são o motor das decisões tomadas pelos credores, que agem premidos por seus interesses individuais, como sempre foi ${ }^{54}$ e sempre será.

Não se está fazendo aqui nenhuma crítica, porque os credores também têm responsabilidade para consigo mesmos (para com a própria função social) ${ }^{55}$. Uma empresa credora, por exemplo, também tem responsabilidade para com os seus consumidores, empregados, financiadores etc, não se podendo esperar que os sacrifique gratuita e espontaneamente em benefício de terceiro.

São exageradamente românticas as afirmações ${ }^{56}$ de que os credores, ao constatarem a viabilidade da empresa em crise, atuarão de modo a preservar a sua função social, só porque agora manda a lei. Ora, os credores irão preservar a empresa quando isso lhes parecer mais interessante, ou seja, quando a continuidade do negócio lhes resultar

\footnotetext{
53 "Análise econômica da nova lei brasileira de falência e recuperação de empresas". Revista de Direito Mercantil, Industrial, Econômico e Financeiro, São Paulo, n. 147, p. 197.

${ }^{54}$ Tal constatação foi mencionada na própria exposição de motivos do Decreto-Lei no $7.661 / 45$, subscrita pelo Ministro Alexandre Marcondes Machado.

55 “A advertência é antiga, mas a realidade pouco mudou, pois é da natureza da atividade empresarial, especulativa no bom sentido da palavra, que o credor persiga seus interesses pessoais, mesmo porque a própria atividade que exerce tem, ela própria, função social" (MAURO RODRIGUES PENTEADO. In: Comentários... Op. cit., p. 73).

${ }^{56}$ Quiçá provocadas pela euforia que permeou a edição da Lei no ${ }^{\text {11.101/2005. }}$
} 
pagamento maior, mais rápido ou for capaz de lhe trazer novas oportunidades comerciais, assim entendidas num sentido amplo.

A preservação da empresa viável, ao menos em princípio, é de interesse social, podendo ser ou não do interesse direto ou indireto de determinado credor, que exercerá o direito de voto na assembleia movido por esse interesse individual, de acordo com os arranjos que se entabularem entre o devedor e os demais credores. É por isso que, ao elaborar o plano de recuperação judicial, deverá o devedor ter especial preocupação com o interesse dos seus credores, de modo a produzir soluções integrativas, cooperativas, que estimulem aquilo que na teoria dos jogos é chamado de "ganha-ganha"57.

Muitas vezes, a maior dificuldade para implementar soluções integrativas, que contemplem os interesses de todos os envolvidos, reside na heterogeneidade dos credores que integram a assembleia, não sendo rara a falta de homogeneidade ${ }^{58}$ até mesmo entre aqueles que compõem a mesma classe ${ }^{59}$.

Daí a necessidade de analisar a composição da assembleia para além das classes definidas pela lei, mirando-se os interesses, sobretudo econômicos, que subjazem às decisões tomadas na assembleia.

Nesse ponto, porém, o objetivo (despretensioso) deste trabalho cinge-se a declarar, a partir de uma observação empírica, quais são os principais atores da Assembleia-Geral de Credores.

$\mathrm{Na}$ prática, as deliberações tomadas pela Assembleia-Geral de Credores são determinadas por três grandes grupos: bancos, empregados e fornecedores. São eles os

\footnotetext{
57 "A partir do momento em que o credor vê seu crédito em risco, o processo de recuperação dependerá de uma negociação coletiva que, necessariamente, será integrativa, cooperativa, do tipo ganha-ganha". (ARISTIDES MALHEIROS. "Plano de recuperação: isso funciona?". Revista do Advogado, São Paulo, n. 105, p. 22).

58 "Os critérios adotados para a constituição das assembleias de credores apresentam um desvio de consistência que podem levar à formação de grupos com preferências internas heterogêneas" (MILTON BAROSSI-FILHO. "As assembleias de credores e plano de recuperação de empresas: uma visão em teoria dos jogos". Revista de Direito Mercantil, Industrial, Econômico e Financeiro, São Paulo, n. 137, p. 233-234).

${ }^{59}$ Essa questão será debatida no item 3.3 do capítulo III.
} 
grandes atores da AGC, em torno dos quais são feitas as negociações e elaborado o plano de recuperação.

\subsection{Bancos}

Com a edição da Lei $n^{\circ} 11.101 / 2005$, a sistemática do regime falimentar brasileiro poderia ser bem definida por esta frase de RIPERT: "É então o reinado dos banqueiros $" 60$.

Via de regra, são os bancos que protagonizam as negociações feitas entre o devedor e os demais credores. Isso se dá não apenas pelo seu poderio econômico e expertise técnica, mas porque a crise da empresa, na maior parte dos casos, é deflagrada justamente quando eles decidem cortar o crédito do devedor, prejudicando-lhe o capital de giro. Noutras palavras, o devedor só é colocado em meio a um processo de recuperação ou falência quando os bancos assim o querem. Logicamente, ao determinarem o timing da instauração do processo de crise, largam com uma enorme vantagem sobre os demais credores.

Além disso, por conta da própria dinâmica do seu negócio, os bancos, entre todos os credores, são aqueles mais bem resguardados: contam com garantias reais sobre os bens do devedor e garantias pessoais dos seus sócios e administradores ${ }^{61}$, e isso quando não se valem dos subterfúgios legais (por eles mesmos articulados) para se furtarem dos efeitos da recuperação judicial, como se dá com contratos de alienação fiduciária e arrendamento mercantil (LRF, art. $\left.49, \S 3^{\circ}\right)^{62}$.

\footnotetext{
${ }^{60}$ No original: "C'est alors le règne du baquier" (Aspects juridiques du capitalisme modern. Paris: Librairie générale de droit et de jurisprudence, 1946, p. 166; tradução livre).

${ }^{61}$ Sabe-se que os bancos, ao concederem empréstimos e linhas de créditos, exigem o aval dos sócios e administradores do devedor. No mais das vezes, embora o patrimônio pessoal deles seja insuficiente para garantir o adimplemento da dívida, essa garantia pessoal exigida pelos bancos constitui poderoso instrumento de pressão sobre aqueles que dirigem a empresa, o que é especialmente preocupante num sistema em que a proposição do plano de recuperação compete exclusivamente ao devedor.

62 "Esta disposição foi o ponto que mais diretamente contribuiu para que a Lei deixasse de ser conhecida como 'lei de recuperação de empresas' e passasse a ser conhecida como 'lei de recuperação do crédito bancário"'(MANOEl Justino BeZERRA FilHo. Nova lei de recuperação e falências comentada. 3 ed. São Paulo: Revista dos Tribunais, 2005, p. 136).
} 
Na Assembleia-Geral de Credores, os bancos costumam integrar a classe dos credores com garantia real e, excepcionalmente, a classe dos credores quirografários quando desprovidos de garantia (o que é raro) ou no caso de o montante do seu crédito suplantar o valor da garantia real que possuem.

Quase sempre deliberam sozinhos na classe dos credores com garantia real; quando muito negociam entre si, nos casos em que há mais de um banco nessa classe, mas não é raro que a deliberação de toda a classe seja tomada pelo voto de um único credor, que acaba por determinar o resultado da própria assembleia.

No âmbito da recuperação judicial, a principal deliberação diz respeito ao plano de recuperação, cuja aprovação depende, em princípio $^{63}$, do voto favorável das três classes de credores que integram a assembleia (trabalhistas, quirografários ou privilegiados e credores com garantia real). Em que pese o juiz possa superar o voto contrário de uma das classes de credores, a aprovação do plano de recuperação sempre depende do voto favorável de mais de 1/3 (um terço) dos credores da classe que o tenha rejeitado (LRF, art. $58, \S \S 1^{\circ}$ e $\left.2^{\circ}\right)$.

Daí que, nos casos em que apenas um banco compõe a classe de credores com garantia real, ou quando o seu crédito corresponde a mais de $2 / 3$ dos créditos da classe - o que não é raro ocorrer -, ele tem o poder de vetar qualquer deliberação que lhe for contrária, sendo irrelevantes os votos favoráveis de todos dos demais credores.

Em outros ordenamentos, como o norte-americano, há instrumentos previstos na própria lei falimentar para superar o voto dissonante de uma classe. O $§ 1.129$ do "Bankruptcy Code" dispõe que o juiz pode conceder a recuperação, a despeito da contrariedade manifestada por alguma das classes, sempre que o plano rejeitado seja viável, respeite a ordem de preferência legal e não implique tratamento diferenciado entre os credores de uma mesma classe. É o que se chama de “cram down”.

${ }^{63}$ Ressalvada a hipótese de "cram down" (LRF, art. 58, $\S 1^{\circ}$ e $2^{\circ}$ ) 
A nossa lei falimentar não possuiu mecanismo semelhante. O nosso "cram down" não passa de um quórum alternativo, que não dá margem ao juiz superar o voto de um único credor que controle mais de $2 / 3$ dos votos de uma única classe.

Ainda assim, o Judiciário brasileiro tem, em determinados casos, superado o veto imposto por um único credor, como forma de atender aos princípios informadores da lei. Por exemplo, o Tribunal de Justiça de Rondônia ${ }^{64}$ decidiu, a despeito do voto contrário do banco que detinha $95 \%$ dos créditos com garantia real, homologar o plano de recuperação da Condesa Norte Indústria e Comércio Ltda. em benefício dos 130 trabalhadores e dos mais de 3.000 fornecedores de leite, aos quais interessava a preservação da empresa devedora.

No mesmo sentido decidiu o Tribunal de Justiça de São Paulo no processo de recuperação judicial da Marbel RC Comércio, Importação e Exportação Ltda. Nesse julgamento, o tribunal paulista destacou que a legislação falimentar pátria não cogitou da hipótese em que o único credor de uma classe rejeite o plano e que, no caso concreto, o veto do banco caracterizava abuso de minoria ${ }^{65}$.

Tais decisões, na prática, são uma tentativa de equilibrar o jogo de forças entre os credores da empresa em crise, que pelos motivos acima declinados, e por conta de muito lobby feito no Congresso, tende sempre a favorecer os bancos.

\footnotetext{
${ }^{64} 1^{\text {a }}$ Câm. Cível, AI 100.010.2006.006147-0, Rel. Des. Gabriel Marques de Carvalho, j. 4.9.2007.

65 "Recuperação judicial - Plano aprovado pela unanimidade dos credores trabalhistas e pela maioria dos credores da classe III do art. 41 e rejeitado por credor único na classe com garantia real - Concessão da recuperação judicial pelo juiz - Agravo de instrumento interposto pelo credor único, com garantia real Preenchimento indiscutível do requisito do inciso II do $\S 1^{\circ}$ do art. 58 (aprovação por duas classes) Preenchimento, também, do requisito do inciso I do $\S 1^{\circ}$ do art. 58 (voto favorável de credores que representem mais da metade do valor de todos os créditos presentes à assembléia, independentemente de classes) - Requisito do inciso III do $\S 1^{\circ}$ do art. 58 que jamais será preenchido, no caso de credor único que rejeite o plano, consagrando o abuso da minoria - Hipótese não cogitada pelo legislador e pelo cram down restritivo da lei brasileira. Juiz que, não obstante, não se exime de decidir, alegando lacuna na lei Inteligência do disposto no art. 126 do CPC, aplicável supletivamente ao caso (art. 189 da nova LFR) Inexistência de tratamento diferenciado entre credores da mesma classe. Falta de legitimidade recursal quanto à dispensa de certidões negativas físcais, além do que, no sentido da r. decisão combatida, existe caudalosa jurisprudência desta Câmara - Decisão de concessão mantida - Agravo de instrumento não provido." (Câmara Especial de Falências e Recuperações, AI nº 638.631-4/1-00, Rel. Des. Romeu Ricupero, j. 18.8.2009).
} 


\subsection{Empregados}

Os empregados, sem dúvida, compõem uma classe de destaque no processo de crise da empresa. Se lhes falta o poderio econômico dos bancos, costumam ser bem organizados, especialmente quando articulados por um sindicato atuante (vide os trabalhadores das indústrias metalúrgicas do grande $\mathrm{ABC}$ ).

Como os seus interesses costumam ser convergentes, é raro haver dissidência entre os credores da classe trabalhista, quase sempre favoráveis às propostas de recuperação da empresa ou de continuidade do negócio na falência, desde que não impliquem demissões. Como agem em coro e com interesses bem definidos, há certa previsibilidade no comportamento desses credores no âmbito da Assembleia-Geral.

Quando em grande número, os empregados são capazes de gerar intensa mobilização em prol da sua causa, tanto da mídia quanto da classe política, como se viu recentemente, com destaque nacional, nos processos de insolvência da VASP e da VARIG.

Constituindo a força-motriz da empresa, os empregados possuem a prerrogativa de cruzarem os braços em greve, o que, a depender da conjuntura da crise e dos interesses envolvidos, pode ser uma arma poderosa, capaz de lhes conceder vantagem em certas negociações. Em alguns casos, porém, a greve trabalhará contra os empregados, agravando uma situação que já é de crise.

A própria lei falimentar defere certos privilégios aos credores trabalhistas ${ }^{66}$. Por exemplo, estabelece que o plano de recuperação não poderá prever prazo superior a um ano para pagamento dos créditos derivados da legislação do trabalho ou decorrentes de acidentes de trabalho (LRF, art. 54), nem prazo superior a 30 dias para o pagamento dos créditos de natureza estritamente salarial vencidos nos três meses anteriores ao pedido de recuperação judicial, até o limite de 5 salários mínimos por trabalhador (LRF, art. 54, par.

\footnotetext{
66 "A principal razão de os credores trabalhistas receberem tratamento diferenciado na legislação falimentar está no fato de não disporem de mecanismos ex ante à proteção de seus interesses - crédito e emprego" (RICARDo NEGRÃO. A eficiência do processo judicial na recuperação de empresa. São Paulo: Saraiva, 2010, p. 183).
} 
único). Já na falência, os créditos trabalhistas, limitados a 150 salários mínimos por credor, gozam de prioridade sobre todos os demais, inclusive sobre os bancos (LRF, art. 83, I).

Com efeito, não se pode ignorar que os empregados são dos mais afetados pela crise da empresa, que lhes atinge o próprio ganha-pão, o sustento das suas famílias. É simplesmente desesperadora a situação dos homens e mulheres que, do dia para noite, veem-se postos na rua, alguns sem mínima chance de recolocação profissional.

Especialmente quando se cuida de grandes empresas, que empregam muitos funcionários, são devastadores para a sociedade os efeitos da quebra. Nas pequenas cidades, onde isto é mais facilmente aferível, a demissão em massa tem efeito cascata sobre todo o comércio, gerando novas demissões. Além disso, faz aumentar a venda e o uso de entorpecentes, bem como os casos de violência doméstica contra mulheres ${ }^{67}$.

É por conta dessa situação que o Judiciário tem-se mostrado sensível à situação dos empregados: até em casos de empresas inviáveis, há exemplos de decisões proferidas para impor a continuidade do negócio e salvaguardar o emprego dos funcionários, não obstante a ausência dos requisitos legais. Eis aí outra realidade que, se não tem propriamente justificativa jurídica, não pode ser desconsiderada no contexto dos processos de insolvência.

\subsection{Fornecedores}

A classe dos credores quirografários é normalmente composta, em grande parte, pelos fornecedores do devedor. Costumam ser em grande número e nem sempre seus interesses são coincidentes. De todas as classes de credores, talvez seja a mais heterogênea.

Há credores que, diante da crise do devedor, preferem cortar relações, receber o máximo possível no menor tempo possível e realizar o prejuízo do que faltar. Outros, por vezes tão dependentes do devedor, não têm o que fazer senão apostar na sua recuperação.

\footnotetext{
${ }^{67}$ A presente afirmação não se faz apoiada em estudos e estatísticas, pois não se logrou encontrá-las, mas a partir da observação empírica de juízes de pequenas comarcas, que concentram todas as competências (cíveis e criminais).
} 
Assim, continuam fornecendo mesmo com prejuízo, na expectativa de novos contratos e de ganhos futuros:

"para os fornecedores, a aprovação do plano é uma estratégia que pode gerar ganhos pela manutenção da atividade e, consequentemente, a formalização de novos contratos" (MARLON TOMAZETTE ${ }^{68}$ ).

Também importa o patrimônio do devedor: se com a falência os credores quirografários nada terão a receber (depois de pagas as classes prioritárias), muito provavelmente estarão interessados na continuidade do devedor, para que este possa auferir novas receitas capazes de, no futuro, saldar a dívida, ou pelo menos parte dela.

Ainda assim, a decisão de cada credor dependerá de outros fatores, como o montante do crédito, a confiança individual na proposta de recuperação e até mesmo a natureza do relacionamento entre os donos e administradores, ou a influência de terceiros com relacionamento em comum com devedor e fornecedores (sempre os bancos) etc.

Nesse contexto, é muito difícil tentar definir, em termos abstratos, um padrão de comportamento dos fornecedores na Assembleia-Geral de Credores. Essa análise depende sempre do contexto fático concreto, sendo infinitas as variações possíveis, justamente pela heterogeneidade de interesses e dos vários fatores que influenciam as decisões da classe.

\section{Credores sujeitos à recuperação judicial}

Dispõe o art. 49, caput, da LRF que se sujeitam à recuperação judicial todos os créditos existentes na data do pedido, ainda que não vencidos ${ }^{69}$. Portanto, pela regra geral, ficariam excluídos dos seus efeitos apenas aqueles cujos créditos forem constituídos após a distribuição do pedido de recuperação judicial. Estes créditos, em caso de falência, serão considerados extraconcursais e, por conseguinte, pagos com precedência sobre os demais previstos na ordem de classificação geral do art. 83 da Lei falimentar (LRF, arts. 67 e 84).

\footnotetext{
${ }^{68}$ Curso de direito empresarial. São Paulo: Atlas, 2011, v. 3, p. 47.

${ }^{69}$ No regime do Decreto-Lei $n^{\circ} 7.661 / 1945$, somente os credores quirografários sujeitavam-se à concordata (art. 147).
} 
A assertiva peremptória constante do caput do art. 49, no sentido de que todos os créditos se sujeitam aos efeitos da recuperação, talvez preconize aquilo que seria ideal, segundo os princípios da par condicio creditorum e da preservação da empresa em crise, mas está dissociada da realidade, pois os créditos efetivamente submetidos à recuperação são somente os seguintes, conforme ensina JORGE LOBO ${ }^{70}$ :

“a) os titulares de créditos decorrentes da legislação do trabalho, não obstante as ações de natureza trabalhista já iniciadas prossigam na Justiça do Trabalho até a apuração do respectivo valor (art. 52, III, c/c o art. $6^{\circ}, \S 2^{\circ}$ ), e os titulares de créditos derivados de acidentes de trabalho, podendo pleitear a reserva das importâncias que estimarem devidas; b) os credores com direitos reais de garantia (CC, arts. 1.419 e s.), com privilégio especial (CC, art. 964) e com privilégio geral (CC,art. 965); c) os credores subordinados (LSA, art. 58, § $4^{\circ}$ ); d) os credores quirografários (LRE, art. 83, VI); e) os credores por multas contratuais (LRE, art. 83, VII); f) os sócios ou acionistas credores".

Há vários créditos que, segundo a própria lei, não se sujeitam aos efeitos da recuperação judicial ${ }^{71}$.

É o caso da União, dos Estados, dos Municípios e do INSS, por dívidas fiscais (LRF, art. $6^{\circ}, \S 7^{\circ}$ e CTN, art. 187), ressalvada a concessão de parcelamento nos termos do Código Tributário Nacional e da legislação ordinária específica. Assim, conforme já decidiu o Tribunal de Justiça do Paraná ${ }^{72}$, "não sendo hipótese de parcelamento ou refinanciamento do débito tributário, inexiste amparo legal que justifique a suspensão da execução fiscal em decorrência do deferimento do plano de recuperação judicial. Aliás, há previsão em sentido contrário na lei”.

JÚLIO KAHAN MANDEL ${ }^{73}$ tece crítica à opção do legislador de não sujeitar os credores fiscais à recuperação judicial, argumentando que a carga tributária é justamente

\footnotetext{
${ }^{70}$ In: TOLEDO, Paulo F.C. Salles de Toledo [et. al.] (Coord.). Lei de Recuperação de Empresas e Falência. 5 ed. São Paulo: Saraiva, 2012, p. 182.

${ }^{71}$ A tal ponto de, em alguns processos, existirem mais credores excluídos da recuperação do que a ela sujeitos.

${ }^{72} \mathrm{AI} n^{\circ}$ 0388574-7/0, Rel. Des. Denise Kruger Pereira, j. 6.3.2007.

${ }^{73}$ Nova lei de falências e recuperação de empresas anotada. São Paulo: Saraiva, 2005, p. 27-28.
} 
uma das maiores causas de ruína das empresas, constituindo o equacionamento da dívida fiscal fator determinante para o soerguimento do devedor:

\begin{abstract}
"foi criada uma proteção injustificável para a Fazenda Pública, proteção essa nociva aos interesses da lei, que é a manutenção da unidade produtiva, pois na prática exclui os créditos físcais da recuperação judicial (o que não acontece com nenhum outro credor), quando se sabe que uma das maiores causas da ruína das empresas é justamente a alta carga tributária, e que não há empresas em dificuldades financeiras que estejam com todos os seus impostos em dia. Prosseguindo a execução fiscal e penhorando-se os bens da empresa devedora durante o prazo de negociação do plano de recuperação com os demais credores, o plano apresentado correrá riscos de ser inviabilizado. Soma-se a isso o previsto no art. 57, que obrigou a empresa em recuperação a apresentar certidões fiscais."
\end{abstract}

Também são excluídos dos efeitos da recuperação judicial, conforme previsto no parágrafo $3^{\circ}$ do art. 49 da LRF, (i) o credor titular da posição de proprietário fiduciário de bens móveis ou imóveis, (ii) o arrendador mercantil, (iii) o proprietário ou promitente vendedor de imóvel cujos respectivos contratos contenham cláusula de irrevogabilidade ou irretratabilidade, inclusive em incorporações imobiliárias, e (iv) o proprietário em contrato de venda com reserva de domínio.

São igualmente ferrenhas as críticas a esse dispositivo, que acaba por privilegiar determinados credores (leia-se: os bancos), em detrimento de todos os demais e da própria preservação da empresa em crise. Nesse sentido, considerando que os bens da empresa objeto de alienação fiduciária, arrendamento ou reserva de domínio não estarão englobados pela recuperação, MANOEL JUSTINO BEZERRA FILHO ${ }^{74}$ pondera que "ficará extremamente dificultada qualquer recuperação, se os maquinários, veículos, ferramentas etc., com os quais a empresa trabalha e dos quais depende para o seu funcionamento, forem retirados ${ }^{, 75}$.

\footnotetext{
${ }^{74}$ Nova lei de recuperação e falências comentada. Op.cit., p. 136.

${ }^{75}$ Ressalva-se apenas que, no prazo de suspensão de 180 dias, contados do deferimento do processamento da recuperação judicial (LRF, art. $6^{\circ}, 4^{\circ}$ ), não se permite a venda ou a retirada do estabelecimento do devedor dos bens de capital essenciais a sua atividade.
} 
Por fim, também ficam imunes os créditos decorrentes de adiantamento a contrato de câmbio para exportação ${ }^{76}$ (LRF, art. $49, \S 4^{\circ}$ c.c. art. 86 , II) e os créditos decorrentes de obrigações assumidas no âmbito das câmaras ou prestadoras de serviços de compensação e de liquidação financeira (LRF, art. 193).

\subsection{A sujeição voluntária dos credores excluídos ao plano de recuperação}

Não há vedação legal que impeça o devedor de incluir no plano de recuperação credores que a ela não se sujeitam. Ocorre que, nesse caso, a eficácia do plano em relação a esses credores dependerá da concordância destes ${ }^{77}$ :

“...cumpre salientar que a Lei de Recuperação e Falências, ao mencionar que tais créditos não se submetem à recuperação judicial, não vedou a sua inclusão no plano apresentado pelo devedor. Assim, se houver a anuência desses credores, seus créditos poderão ser incluídos na recuperação" (MODESTO CARVALHOSA ${ }^{78}$ ).

Alguns autores, como MARIO SERGIO MiLANI ${ }^{79}$, chegam mais longe, afirmando que tais credores se sujeitam ao plano de recuperação quando não tenham se oposto a ele. Segundo tal raciocínio, a vinculação desses credores dispensaria, portanto, a manifestação da sua aceitação:

"Nada impede que tais credores (...) sejam incluídos pelo devedor no plano de recuperação, até porque, tratando-se de direito disponível, se eles não se opuserem, o juiz concederá a recuperação englobando-os”.

\footnotetext{
${ }^{76}$ No adiantamento a contrato de câmbio para exportação, ou ACC, o exportador, após contratar a venda de seu produto ao Exterior, procura o agente de câmbio, obtendo em moeda nacional o valor que receberia, após a entrega do produto. Entregue o produto no Exterior, o importador paga diretamente ao banco, liquidando-se a operação. Caso o exportador não entregue o produto e sua falência seja decretada, o banco pode pedir a restituição da importância adiantada (LÍDIA VALÉRIO MARZAGÃO. “A recuperação judicial” In: MACHADO, Rubens Approbato (coord.). Comentários à nova lei de falências e recuperação de empresas. 2 ed. São Paulo: Quartier Latin, 2007, p. 89).

77 O que é raro, conforme salienta MANOEL Justino BEZERRA FILHO: "é necessário ressaltar que a Lei, ao dizer que tais créditos não se submetem à recuperação judicial, mesmo assim não proibiu a inclusão deles no plano. Se houver - embora extremamente improvável - anuência do credor, estes valores podem ser incluídos na decisão que concede a recuperação na forma do art. 58" (Nova lei de recuperação e falências comentada. Op.cit., p. 137).

${ }^{78}$ In: Comentários à nova lei de falência... Op. cit., p. 281.

${ }^{79}$ Lei de recuperação judicial, recuperação extrajudicial e falência comentada. São Paulo: Malheiros, 2011, p. 214-215.
} 
Com a devida vênia, essa não parece ser a solução correta, pois não há norma que imponha aos credores excluídos o dever de objetar o plano de recuperação que os vincule, nem consequência para a sua inação. Daí que, não havendo manifestação da sua concordância, o plano de recuperação (mesmo aprovado e homologado) será ineficaz em relação a esses credores, conforme ensina ERASMO VALLADÃo FRANÇA ${ }^{80}$ :

"De maneira geral, pode-se dizer que são ineficazes as deliberações que alteram, ou sejam suscetíveis de alterar direito especiais de credores ou direitos de terceiros antes que estes consintam".

Portanto, razão assiste a FÁBIO UlHOA COELHO ${ }^{81}$ ao afirmar, embasado na jurisprudência do Tribunal de Justiça de São Paulo ${ }^{82}$, que "o credor não sujeito à recuperação judicial não passa a ser alcançado pelos efeitos desta somente porque ocorreu a inclusão de seu nome no plano de recuperação, mesmo tendo sido homologado pelo juiz, a despeito de objeções articuladas”.

\section{Direitos dos credores no modelo da structured bargaining}

Por pressão do Fundo Monetário Nacional e influência das diretrizes do Banco Mundial $^{83}$ (os chamados principles and guidelines for effective insolvency and creditor rights systems), a lei brasileira acabou por filiar-se ao sistema da structured bargaining (em vernáculo, negociação estruturada), que tem no Código de Falências norte-americano a sua expressão mais conhecida.

${ }^{80}$ Comentários...Op. cit., p. 190.

${ }^{81}$ Comentários à Lei de Falência. 9 ed. São Paulo: Saraiva, 2012, p. 185.

82 “(...) ainda que por hipótese seu crédito continue a figurar no plano de recuperação homologado, não perde (o credor não sujeito) o direito de se valer da execução individual na forma da lei de regência” (Câm. Reserv. Falência e Recup., AI nº 994.09.336598-8, Rel. Des. Eliot Akel, j. 26.1.2010).

83 Conforme MaUro Rodrigues PenteAdo: "Somente após o Poder Executivo federal haver assumido compromisso perante o Fundo Monetário Internacional para aprovar uma nova lei de falências, visando melhorar o 'ambiente' e os chamados 'marcos legais' do mercado brasileiro, é que a tramitação do projeto ganhou impulso e passou a figurar com prioridade na agenda do Congresso, acabando por ser aprovado, com profundas modificações e a incorporação de mecanismos indicados em diretrizes ('principles and guide lines') de organismos internacionais" (In: In: SOUZA JUNIOR, Francisco Satiro; PITOMBO, Antônio Sérgio de Moraes (Coords.). Comentários à Lei de Recuperação de Empresas e Falências. São Paulo: Revista dos Tribunais, 2005, p. 58). 
Segundo OLIVER HART ${ }^{84}$, Professor de Economia da Universidade de Harvard, a ideia por trás dos procedimentos baseados na structured bargaining é a de que os credores da empresa sejam incentivados a negociar sobre o futuro da empresa devedora se deve ser liquidada ou reorganizada e como seu valor deve ser dividido - de acordo com regras predeterminadas.

O maior exemplo de um processo baseado na structured bargaining, segundo HART, é o Capítulo 11 do Código de Falências dos EUA ${ }^{85}$, cujos principais elementos são os seguintes: as cobranças dos credores ficam sobrestadas (a nenhum credor é permitido apreender ou vender qualquer um dos ativos da empresa devedora durante o processo), os credores são agrupados em classes de acordo com a natureza do seu crédito (com garantia ou sem, privilegiados ou não), e um juiz supervisiona o processo de negociação entre os representantes das classes para determinar um plano de ação e uma divisão de valor para a empresa. Durante o processo, a gestão normalmente compete aos próprios administradores da empresa devedora. Além disso, para que um plano possa ser implementado, basta a aprovação da maioria dos credores integrantes de cada classe, sendo dispensada a unanimidade.

Ainda que com significativas particularidades em relação ao modelo norteamericano $^{86}$, várias das características da negociação estruturada podem ser observadas na Lei $\mathrm{n}^{\circ} 11.101 / 2005$, que fez com que os credores passassem de meros espectadores a

84 (Different Approaches to Bankruptcy. Disponível em: http://ww.nber.org/papers/w7921, acesso em: 18.12.2012, p. 7-8; tradução livre). No original: "Because of the concern about the effectiveness of cash auctions, a number of countries have developed alternative procedures based on the notion of structured bargaining. The idea behind these procedures is that the firm's claimants are encouraged to bargain about the future of the firm--whether it should be liquidated or reorganized and how its value should be divided up-according to predetermined rules. The leading example of a structured bargaining procedure is Chapter 11 of the U.S. Bankruptcy Code (...). The basic elements of Chapter 11 are as follows. A stay is put on creditors' claims (that is, they are frozen: no creditor is allowed to seize or sell any of the firm's assets during the process); claim holders are grouped into classes according to the type of claim they have (secured or unsecured, senior or junior); and a judge supervises a process of bargaining among class representatives to determine a plan of action and a division of value for the firm. During the process, incumbent management usually runs the firm. An important part of the procedure is that a plan can be implemented if it receives approval by a suitable majority of each claimant class; unanimity is not required."

${ }^{85}$ A respeito do tema, confira-se SHEILA CHRISTINA NEDER CEREZETTI. "O papel dos credores no Bankruptcy Code". RDM, São Paulo, n. 151/152, p. 164-186, 2009.

${ }^{86}$ Como a exclusão de diversos credores dos efeitos da recuperação, a vedação da aprovação de plano de recuperação alternativo sem a concordância do devedor, a excessivamente simplista divisão dos credores em apenas três classes, a ausência de mecanismo efetivo de superação do voto dissidente das classes de credores, a rigidez do prazo para apresentação do plano de recuperação e da suspensão das ações contra o devedor, as limitadas competências conferidas ao Comitê de Credores, entre outras. 
protagonistas ${ }^{87}$ do processo de insolvência, gozando da prerrogativa de decidir a solução à crise do devedor em comum (conceder a recuperação ou impor a falência).

A seguir, serão analisados os principais direitos dos credores segundo o modelo de negociação estruturada adotado pela lei de insolvência nacional.

\subsection{Direito de aprovar ou rejeitar o plano de recuperação}

Entre os direitos conferidos aos credores, sem dúvida o mais importante consiste no direito de aprovar ou não o plano de recuperação apresentado pelo devedor.

No regime anterior o deferimento da concordata dependida apenas do preenchimento de certos requisitos objetivos e subjetivos, entre os quais não se encontrava a concordância do credor. Isto é, quisesse ele ou não, fosse ou não viável a concordatária, era ele obrigado a suportar a remissão de parte da dívida ou enfrentar a moratória.

Agora, o deferimento da recuperação judicial depende, obrigatoriamente, da concordância dos credores $^{88}$, seja pela aprovação do plano na AGC, seja pela ausência de objeções formuladas legal (LRF, art. 58). Quer isso dizer que, em regra, se os credores preferirem a falência à recuperação, o juiz deverá decretar a quebra (LRF, art. 56, $\left.\S 4^{\circ}\right)^{89}$.

Ressalvadas hipóteses excepcionais, de abuso ou fraude, não poderá o juiz contrariar aquilo que tenham decidido os credores, isto é, não poderá conceder a recuperação com base em plano rejeitado, nem denegar o pedido se os credores houverem

\footnotetext{
87 “Os credores, com a LRE, subiram na escala dos sujeitos processuais da recuperação de empresas (judicial ou extrajudicial) e das falências. De meros espectadores, que na antiga concordata não chegavam a manifestar sua concordância, passam a protagonistas da história da empresa em crise, decidindo, no ato final, se ela poderá sobreviver ou se irá quebrar" (PAUlo F. C. SALlES DE TOLEDO. "Recuperação judicial: a principal inovação da Lei de Recuperação de Empresas - LRE”. Revista do Advogado, São Paulo, n. 83, p. 103)

${ }^{88}$ Nem mesmo a recuperação especial das pequenas e microempresas será concedida se houver objeções de credores titulares de mais da metade dos créditos quirografários (LRF, art. 72, par. único).

${ }^{89}$ Art. 56, § 4 , da LRF. Rejeitado o plano de recuperação pela assembléia-geral de credores, o juiz decretará a falência do devedor.
} 
aceitado o plano. A lei não lhe dá esta discricionariedade ${ }^{90}$, conforme pondera ALBERTO CAMINÃ MOREIRA ${ }^{91}$ :

"o pronunciamento judicial, seja na hipótese de aceitação do plano, seja na hipótese de rejeição do plano, é meramente homologatório e disso não deixa dúvida o disposto no art. $59, \S 1^{\circ}$ (...). Não há, pois, decididamente, julgamento do plano de recuperação judicial, como não há julgamento da separação consensual de um casal; a atividade jurisdicional é a de homologação da vontade dos credores e devedores. (...) "ao atribuir tal tarefa a um órgão [a AGC], a lei, ipso facto, retira-a de qualquer outro, inclusive do juiz. Não há, pois, possibilidade de estabelecer qualquer espécie de conflito, no concernente ao exame do plano de recuperação, entre a assembléia de credores e o juiz. Foi subtraído do juiz, a princípio, a possibilidade de examinar o plano de recuperação judicial e de impô-los aos credores, com a exceção que será examinada mais a frente."

Nesse sentido, em que pese a opinião contrária de alguns doutrinadores ${ }^{92}$, é assim que têm se posicionado os tribunais, notadamente a Câmara de Falência e Recuperação Judicial do Tribunal de Justiça de São Paulo, que por sua especialidade e capacidade técnica dos seus membros, tem ditado a interpretação prevalecente no País ${ }^{93}$ :

\footnotetext{
${ }^{90}$ Nesse sentido: "O entendimento no sentido de que o juiz não dispõe de discricionariedade para conceder a recuperação judicial sem a aprovação da assembléia-geral ... ajusta-se perfeitamente à lei de regência." (TJSP, Câm. Fal. e Recup., AI no 558.460-4/8-00, Rel. Des. Eliot Akel, j. 24.9.2008 - destacou-se).

91 "Poderes da assembléia de credores, do juiz e atividade do Ministério Público". In: PAIVA, Luiz Fernando Valente de (coord.). Direito Falimentar e a Nova Lei de Falências e Recuperação de Empresas. São Paulo: Quartier Latin, 2005, p. 252 e 253).

${ }^{92}$ Admitindo que o juiz pode denegar a recuperação se entender que o plano é inconsistente, afirma FÁBIO UlhoA CoElho: "Pela lei brasileira, os juízes, em tese, não poderiam deixar de homologar os planos aprovados pela Assembleia dos Credores, quando alcançado o quórum qualificado da lei. Mas, como a aprovação de planos inconsistentes levará à desmoralização do instituto, entendo que, sendo o instrumento aprovado um blá-blá-blá inconteste, o juiz pode deixar de homologá-lo e incumbir o administrador judicial, por exemplo, de procurar construir com o devedor e os credores mais interessados um plano alternativo". (Comentários...Op. cit., p. 224).
}

No mesmo sentido leciona NEWTON DE LUCCA: "Imagine-se um plano visivelmente inconsistente que venha a ser aprovado pela assembleia de credores (não por convicção íntima destes no êxito do plano, de resto um grotesco mistifório, mas sim à míngua de alguma alternativa para eles que não a declaração da falência do devedor...): Estaria o juiz obrigado a aceitá-lo? Também aqui, a meu ver, a resposta deverá ser igualmente negativa. Não vejo como possa entender-se que o magistrado, convencido da inconsistência do plano, esteja obrigado a fazer o papel de inocente útil, referendando uma solução que, de antemão, sabe ser absolutamente inadequada...”(Comentários à nova lei de recuperação de empresas e falências. São Paulo: Quartier Latin, 2005, p. 33).

${ }^{93}$ É natural que, por ser o centro econômico-financeiro do País, onde se encontra a maior parte das empresas, o Estado de São Paulo concentre o maior número de casos e discussões envolvendo processos de insolvência, o que enseja a especialização e o aprimoramento técnico das decisões. 
"Esta Câmara Especializada tem se pronunciado no sentido de que em relação à proposta do plano de recuperação da empresa, a AssembléiaGeral é soberana, não podendo o juiz, nem o Ministério Público, imiscuir-se no mérito do plano, em sua viabilidade econômicofinanceira (...). caberá aos credores examinarem os pareceres técnicos e concluir pela viabilidade ou inviabilidade econômico-financeira da proposta da empresa devedora. Somente em casos em que se demonstre abuso de direito por algum credor que imponha sua vontade à assembléia para rejeitar o plano é que se tem admitido, em casos excepcionais, nova oportunidade de ser deduzido outro plano a ser submetido também à assembleia geral de credores. (...) Em suma: sendo o plano aprovado regularmente pela Assembléia-Geral de Credores com o quorum previsto no artigo $45^{\circ}, \S \S 1^{\circ}$ e $2^{\circ}$, com observância de todas as formalidades legais, não pode o magistrado deixar de conceder a recuperação judicial por entender que o plano é inviável sob o prisma econômico-financeiro."94

\subsection{Direito de propor alterações ao plano de recuperação}

Os credores não estão obrigados a simplesmente aceitar ou rejeitar o plano, podendo propor-lhe alterações, desde que não impliquem diminuição apenas dos direitos daqueles ausentes à assembleia (LRF, art. 56, § $\left.3^{\circ}\right)$.

Essa disposição é bastante positiva e tem o mérito de não engessar o processo da recuperação, que há de ser, efetivamente, uma solução negociada entre credores e devedor. Pois quanto mais intensamente participarem os credores, quanto mais valorizadas forem as suas contribuições, mais eficiente tende a ser a solução final do processo, inclusive por gozar de maior legitimidade.

Tanto isso é verdade que, na prática, os juízes têm abrandado os rigorismos ${ }^{95}$ formais da lei para permitir a realização de várias assembleias destinadas a discutir e

\footnotetext{
${ }^{94} \mathrm{AI} \mathrm{n}^{\mathrm{o}} 561.2$ 71-4/2-00, Rel. Des. Pereira Calças, j. 30.7.2008.

95 “...é de se indagar se a rigidez do dispositivo ( "o juiz decretará a falência” pelo "descumprimento de qualquer obrigação prevista no plano”) não está a merecer algum temperamento. Cabe a pergunta: verificado o descumprimento de qualquer obrigação prevista no plano, deve mesmo o juiz decretar incontinenti a convolação da recuperação judicial em falência? (...)A melhor interpretação do disposto neste art. 73 sugere, portanto, a mitigação da dureza e inflexibilidade do comando nele contido. Ao invés de aplicar-se in litteram legem, o que reza a Lei ("o juiz decretará a falência...”), conviria dar-lhe algum polimento, para ali ler-se "o juiz poderá decretar a falência”, o melhor se coadunaria com o espírito que deve presidir a aplicação da Lei." (In: SOUZA JÚNIOR, Francisco Satiro de; PITOMBO, Antônio Sérgio de Moraes (Coords.). Comentários à Lei de Recuperação de Empresas e Falência. São Paulo: Revista dos Tribunais, 2005, p. 328-329).
} 
rediscutir o plano ${ }^{96}$, evitando assim a decretação compulsória da quebra, como se de mera consequência processual se tratasse.

“A experiência tem mostrado que várias assembleias gerais de
credores têm sido designadas com o escopo de analisar e reanalisar as
diversas propostas apresentadas e reapresentadas pela recuperanda. A
flexibilidade disposta na norma é consentânea com o objetivo da Nova
Lei de Falências e Recuperação de Empresas - não existe nenhuma
fórmula 'estanque' para a reestruturação empresarial; o devedor pode
estar enxergando a viabilidade de recuperação de forma distorcida da
realidade dos credores, principais destinatários, em princípio, do plano
de recuperação" (MÁRCIO GUIMARÃES

Com efeito, os juízes não devem aplicar a regra do art. $56, \S 4^{\circ}$, da LRF - que lhe determina a decretação da falência se rejeitado o plano pela AGC - como se estivessem declarando a revelia numa cautelar de busca e apreensão: cuida-se de dever ético ${ }^{98}$ dos magistrados, ao proferir decisões, atuar de forma cautelosa, atento às consequências que pode provocar (no mais das vezes irreversíveis ante a decretação da quebra).

É de fundamental importância para todo processo de recuperação a sensibilidade do juiz ${ }^{99}$, que não deverá decretar a falência se vislumbrar que a negociação está sendo conduzida de boa-fé, em atenção aos princípios norteadores da lei, e que há efetiva possibilidade de composição. Nesses casos, poderá até mesmo autorizar que o plano seja refeito, aditado ou corrigido ${ }^{100}$, com a convocação de nova(s) assembleia(s),

96 EdUARDo FOZ MANGE cita que, na recuperação judicial das empresas Parmalat e Latina Construtora e Pavimentadora Ltda., a AGC foi várias vezes suspensa para que fosse obtido consenso quanto ao plano e suas alterações. (Assembleia-Geral de Credores na recuperação judicial. Dissertação de mestrado, São Paulo: Faculdade de Direito da PUC-SP, 2010. p. p. 71-72).

${ }^{97}$ In: CORRÊA-LIMA, Osmar Brina; e LIMA, Sérgio Mourão Correa (coords.). Comentários à nova Lei de Falência e Recuperação de Empresa. Rio de Janeiro: Forense, 2009, p. 393.

${ }^{98}$ Art. 25 do Código de Ética da Magistratura, aprovado pelo Conselho Nacional de Justiça em sessão do dia 06 de agosto de 2008.

99 Segundo JOSÉ RENATO NALINI: "O juiz precisa ter consciência de que a sua decisão repercutirá no meio social e ele necessita ter noção precisa dessas consequências. Por isso é que a sensibilidade para avaliar as consequências da decisão, o conhecimento da realidade e o amor ao estudo constituem algumas das faces do compromisso ético do juiz brasileiro". (Ética Geral e Profissional. 8 ed., São Paulo: Revista dos Tribunais, 2011, p. 450; destaques do original).

${ }^{100}$ Nesse sentido: “Agravo de instrumento. Recuperação judicial. Pedido de convocação de nova assembléia de credores, formulado pela empresa recuperanda, com o intuito de apresentar proposta de modificação do plano anteriormente aprovado. Situação não prevista pela lei que, ao mesmo tempo, não está nela vedada. As particularidades do caso concreto, em face do princípio da preservação da empresa, pela sua função social, na forma do art. 47 da Lei $n^{\circ} 11.101$, recomendam seja concedida a oportunidade. Recurso provido" (TJRS, $6^{\text {a }}$ Câm. Cív. AI no 70040733479, Rel. Des. Ney Wiedemann Neto, j. 28.04.2011). 
quando lhe parecer que tal medida mais bem atende a vontade dos credores e aos interesses dos stakeholders, pois nem sempre a rejeição do plano apresentado significa que os credores preferem a quebra à recuperação ${ }^{101}$.

Além de mais consentânea com o princípio da preservação da empresa, essa conclusão também decorre da interpretação sistemática do art. $56, \S 4^{\circ}$, da LRF. Afinal, é dever e prerrogativa do juiz, expressa pelo art. 125, IV, do Código de Processo Civil, “tentar, a qualquer tempo, conciliar as partes”. É, também, um dos principles and guide lines do Banco Mundial, segundo o qual "as decisões judiciais devem encorajar a resolução consensual entre as partes quando possível"102.

Quisesse o legislador excluir do magistrado esse juízo de oportunidade, teria declarado o devedor falido pela só rejeição do plano (isto é, como um efeito automático). Porém, ao dispor que o juiz decretará a falência, quis a lei garantir que a quebra passasse pelo crivo de um agente estatal comprometido com os valores constitucionais: "rejeitar $o$ plano é papel conferido exclusivamente à assembleia; declarar a falência é ato exclusivamente jurisdicional" ${ }^{103}$. Como tal, na aplicação da norma, deverá o juiz atender aos fins sociais a que ela se destina e às exigências do bem comum, conforme determina $\mathrm{o}$ art. $5^{\circ}$ Lei de Introdução às normas do Direito Brasileiro (Decreto-Lei no 4.657/42).

Para que fique bem claro, não se está aqui advogando que o juiz possa, num juízo de discricionariedade, desconsiderar a determinação dos credores (para aprovar plano rejeitado ou recusar plano aprovado). Há doutrinadores que realmente assim o entendem $^{104}$, mas não é disso que aqui se cuida. O que se pondera é que, no contexto de

\footnotetext{
${ }^{101}$ Em sentido contrário, o Tribunal de Justiça de São Paulo, já decidiu que "ao receber a ata da assembleia, contendo a decisão de rejeitar o plano, o juiz deve prolatar a sentença declaratória de falência, atendidos os requisitos do art. 99. A declaração da falência é consequência imediata da decisão da assembleia de rejeição do plano. Não há outro caminho procedimental a seguir" (Câm. de Fal. e Recup, AI no 461.740-4/4-00, Rel. Des. Pereira Calças, j. 28.2.2007).

${ }^{102}$ Principles for effective insolvency and creditor rights systems. Texto revisado em 2005. No original: "D5.1 Judicial Decision Making. Judicial decision making should encourage consensual resolution among parties where possible, and should otherwise undertake timely adjudication of issues with a view to reinforcing predictability in the system through consistent application of the law."

${ }^{103}$ Cf. TJSP, Câm. de Fal. e Recup, AI no 461.740-4/4-00, Rel. Des. Pereira Calças, j. 28.2.2007.

${ }^{104}$ Entre outros, JORGE LOBO afirma que o juiz poderá superar a rejeição dos credores ao plano para conceder a recuperação judicial: "A meu ver, a interpretação sistemática, teleológica e pragmática, defendida nos comentários aos arts. 47 , itens 9 e 10, e 58, itens 1 e 2, leva à conclusão que o juiz não pode ser privado dos poderes e atribuições que lhe são assegurados por norma constitucional e pela LOMAN, nem impedido de
} 
um processo de insolvência, o juiz deve zelar para que prevaleça a vontade real dos credores, e não aquela deduzida a partir da aplicação inconsequente de uma regra contaminada por uma visão excessivamente processualista da insolvência.

Não se discorda de Eduardo Secchi Munhoz ${ }^{105}$ quando afirma que "no modelo ora implantado, o juiz não exerce o papel de árbitro dos diversos interesses em jogo, capaz de decidir de acordo com o melhor interesse da sociedade, (...) mas confia-se na negociação direta entre os diversos titulares de interesse”.

De fato, não cabe ao juiz tomar a frente das negociações, o que não significa, porém, que não deva supervisioná-las ${ }^{106}$, criando o ambiente mais propício à composição: ao se desprender de formalismos exagerados, tendo em vista os aspectos econômicos da negociação, não estará o magistrado fazendo outra coisa senão ajustar-se ao sistema da structured bargaining $^{107}$, ao qual a lei concursal brasileira claramente se filiou ${ }^{108}$.

Aliás, não é de hoje que se verifica que a concepção preponderantemente processualista da falência produz efeitos danosos ${ }^{109}$. Como bem destaca NELSON ABRÃO ${ }^{110}$,

exercer o controle da legalidade formal e substancial e, conforme o caso, o controle de mérito e decidir se a rejeição do plano pela assembleia geral de credores: a) atenta contra o interesse público; b) encerra indisfarçável fraude; c) importa em violação da LRE etc., o que obrigará o juízo a ir contra a "letra" do art. $56, \S 4^{\circ}$, e a não decretar a falência" (In: Comentários à lei de recuperação... Op. cit., p. 216). Por outro lado, FÁbio UlhoA COElHo e NEWTON DE LuCCA admitem que o juiz possa deixar de homologar aprovação de um plano que repute inconsistente (vide nota de rodapé $\mathrm{n}^{\circ}$ 92).

${ }^{105}$ In: SOUZA JUNIOR, Francisco Satiro; PITOMBO, Antônio Sérgio de Moraes (Coords.). Comentários à Lei de Recuperação de Empresas e Falências. São Paulo: Revista dos Tribunais, 2005, p. 279-280.

${ }^{106}$ Um dos elementos básicos da structured bargaining, segundo a sistemática do Bankrupty Code norteamericano, é justamente que "um juiz supervisione o processo de negociação entre os representantes das classes para definir o plano de ação" (OLIVER HART. Different Approaches to Bankruptcy. Disponível em: http://ww.nber.org/papers/w7921, acesso em: 18.12.2012, p. 7-8; tradução livre). No original: "The leading example of a structured bargaining procedure is Chapter 11 of the U.S. Bankruptcy Code (...).The basic elements of Chapter 11 are as follows. (...) and a judge supervises a process of bargaining among class representatives to determine a plan of action and a division of value for the firm."

${ }^{107}$ Acerca da definição de structured bargaining, confira-se o item 3, acima.

108 “Os $\S \S 2^{\circ}$ e $3^{\circ}$ do art. 56 (além de outros dispositivos) revelam que a Lei, embora tenha claramente se filiado ao sistema da negociação entre devedor e credores (structured bargaining), afastando-se do modelo de índole fortemente processualista adotado pelo Dec.-lei de 1995, mantém um processualismo ingênuo ao regular o processo de negociação, olvidando os aspectos econômicos que o envolvem." (EDUARDO SECCHI MunHOZ. Comentários... Op. cit., p. 275).

109 Conforme Nelson ABRÃo, "um dos primeiros a se aperceber dos efeitos danosos da concepção preponderantemente ou exclusivamente processualista da falência foi Ascarelli. Assim é que assinala o mestre italiano, em seu 'Corso di Diritto Comerciale', página 307, Milão, 1962 que 'no envolver de nossa legislação foi colocada uma conotação mais marcadamente processual no instituto (...). Daí a crise do 
“a patologia do juízo ... não está nas formas, mas no formalismo, que não é imputável ao legislador, mas aos juízes, às partes, à ciência, à escola”.

Não se ignora que realização de nova assembleia é custosa. Por isso, impõe-se ao magistrado ponderar a sua conveniência diante das particularidades do caso concreto, considerando o perfil do devedor, o ramo de atividade, o porte da empresa, a composição dos credores, a importância da empresa para a região ou para todo o País etc.

Nem poderia a lei, dotada de generalidade e abstração, prever todas as hipóteses concretas a ensejar a sua incidência. É por isso que cabe ao operador do direito aplicar a norma tendo em conta a realidade que se lhe apresenta, com todas as suas nuances e peculiaridades, sob pena de cometer o despautério de tratar de modo idêntico e simplista fenômenos econômicos tão dispares como a insolvabilidade de uma loja de armarinho e uma multinacional da exportação, como bem advertiu FABIO KONDER COMPARATO ${ }^{111}$.

Registre-se, por fim, a opção do nosso legislador de condicionar a aprovação de quaisquer alterações no plano de recuperação à concordância do devedor (LRF, art. 56, $\S 3^{\circ}$ ), sem prever instrumentos para superar a discordância ${ }^{112}$ : “o plano de recuperação

instituto falimentar, que terminou por esquecer a peculiaridade dos problemas para a solução dos quais é entendido o instituto"' (A continuação do negócio na falência. São Paulo: Leud, 1975, p. 38).

FÁBIO KONDER COMPARATO também dá razão a Ascarelli: "No enfrentar essa crise, como também assinalou o mestre, a pior solução é persistir na orientação marcadamente processualista e que tem prevalecido no direito italiano e também, diremos nós, por via de servil imitação, no direito brasileiro. O instituto foi criado pelos práticos da Idade Média tendo em vista justamente subtrair a insolvência do devedor comerciante à esfera das normas antieconômicas do processo comum. É imperdoável que o legislador do Século XX se deixe deslumbrar pelos ouropéis da moderna processualística, olvidando os problemas especificamente econômicos que a insolvência não deixa de suscitar, mormente quando atinge as grandes empresas." (Aspectos jurídicos da macro-empresa. São Paulo: Revista dos Tribunais, 1970, p. 107 e 108).

${ }^{110}$ Idem, p. 40.

${ }^{111}$ Aspectos jurídicos da macro-empresa. São Paulo: Revista dos Tribunais, 1970, p. 1-2.

${ }^{112} \mathrm{Na}$ Alemanha, quando o plano tiver sido apresentado pelo administrador judicial, também se exigirá a concordância do devedor. Contudo, eventual discordância sua poderá ser superada pelo juiz, desde que preenchidos alguns requisitos (InsO, art. 247). É o que ensina ARIEL ÁNGEL DASSO, Professor de Direito da Universidade de Buenos Aires: "Mas não só os credores podem ser sujeitos ao cramdown, ou à submissão de sua vontade: quando o plano tiver sido apresentado pelo administrador da insolvência, o devedor deve dar a seu concordância ao mesmo. Dita conformidade é pressuposta quando o devedor não impugna o plano (art. 247, I), mas o juiz pode de qualquer maneira impô-lo desde que o devedor não seja colocado no plano em situação pior do que aquela em que se encontraria sem o mesmo, e nenhum credor obtenha um valor econômico que exceda a totalidade do seu crédito (art. 247, II, 1 e 2)". (Derecho Concursal Comparado. Buenos Aires: Legis argentina, 2009, t. 1, p. 22; tradução livre). No original: "Pero no sólo los acreedores pueden ser sujetos de cramdown, o sometimiento de su voluntad: cuando el plan hubiere sido presentado por el administrador de la insolvência, el deudor debe prestar su conformidad al mismo. Dicha conformidade se 
pode sofrer alterações na assembléia-geral, desde que haja expressa ${ }^{113}$ concordância do devedor".

Tal disposição pode ser explicada a partir da concepção eminentemente contratualista da recuperação, em que o plano resulta do acordo de vontade do devedor com a maioria dos credores. EDUARDO SECCHI MUNHOZ ${ }^{114}$ critica a opção legislativa, por privilegiar o interesse individual do empresário em detrimento da empresa:

"De uma perspectiva voltada para a função social da empresa e, por consequência, para a tutela dos diversos interesses em jogo em torno dela, que vão muito além do interesse dos seus sócios e administradores, seria de se admitir a aprovação de um plano de recuperação que se demonstrasse viável economicamente e que, além disso, contasse com o amplo apoio do conjunto de stakeholders (credores, trabalhadores etc.), ainda que o devedor (ou, melhor dizendo, sócios ou administradores do devedor) discordasse de sua implantação. Ao vedar essa possibilidade de forma absoluta, exigindo que o plano eventualmente modificado pela assembléia geral conte necessariamente com a anuência do devedor, a lei brasileira pode levar a soluções incompatíveis com a função social da empresa. Assim, entre proteger o interesse pessoal do empresário (sócios ou administradores do devedor) e salvar a empresa (havida como centro de múltiplos interesses), a lei brasileira preferiu a primeira solução."

O mesmo doutrinador anota que, a despeito da influência do direito falimentar norte americano sobre a lei brasileira, neste ponto os sistemas não coincidem. Destaca que o $\$ 1121$ (c) do Bankruptcy Code ${ }^{115}$, diferentemente da lei brasileira, permite a qualquer

supone, cuando el deudor no impugna el plan (art. 247, I), pero el juez puede de todos modos imponérselo a condición de que el deudor no estuviere a causa del plan en peor situación que aquella en que se encontraria sin el mismo, y ningún acreedor obtuviere un valor económico que sobrepase la totalidade de su pretensión (art. 247. II. 1 y 2).”

113 “A concordância do devedor poderá ser manifestada mediante: (a) documento escrito, particular ou público; e (b) aposição de sua assinatura na ata dos trabalhos da assembléia-geral ou no plano de recuperação consolidado, após sofrer alterações" (JORGE LOBO. In: TOLEDO, Paulo Campos Salles de; e ABRÃO, Carlos Henrique (coords.). Comentários à Lei de Recuperação de Empresas e Falência. 5 ed. São Paulo: Saraiva, 2012, p. 215).

${ }^{114}$ In: SOUZA JUNIOR, Francisco Satiro; PITOMBO, Antônio Sérgio de Moraes (Coords.). Comentários à Lei de Recuperação de Empresas e Falências. São Paulo: Revista dos Tribunais, 2005, p. 276-277.

$115 \S 1121$ (c). Any party in interest, including the debtor, the trustee, a creditors' committee, an equity security holders' committee, a creditor, an equity security holder, or any indenture trustee, may file a plan if and only if - (1) a trustee has been appointed under this chapter; (2) the debtor has not filed a plan before 120 days after the date of the order for relief under this chapter; or (3) the debtor has not filed a plan that has been accepted, before 180 days after the date of the order for relief under this chapter, by each class of claims or interests that is impaired under the plan. 
credor (entre outros interessados) apresentar o plano de recuperação (i) se o devedor não o fizer no prazo legal, (ii) se o plano apresentado pelo devedor não for aprovado no prazo de 180 dias, ou ainda (iii) se o devedor for afastado da condução da atividade, com a nomeação de um trustee ${ }^{116}$.

Interessante compartilhar um pouco da experiência americana e conhecer as razões que levaram o Congresso, em 1978, a retirar do devedor a exclusividade de que até então gozava na apresentação do plano de recuperação.

A esse respeito, CHARLES JORDAN $\mathrm{TABB}^{117}$, Professor de Direito da Universidade de Illinois, relata que quando os capítulos do Código que disciplinavam a reorganização foram fundidos num único (o mundialmente conhecido Chapter Eleven), o Congresso teve de pesar interesses conflitantes para escolher quem deveria ter o direito de apresentar o plano.

\footnotetext{
${ }^{116}$ Equivalente, no Brasil, à figura do "gestor judicial", nomeado no caso de afastamento do devedor pelo juiz em casos de crime, fraude, negligência ou grave incompetência administrativa (LRF, art. 65).

117 The Law of Bankruptcy. Nova Iorque: The Foundation Press, 1997, p. 808-809; tradução livre. No original: "In choosing the best rule on who should have the right to file a plan when it merged the reorganization chapters in 1978, congress had to weigh competing concerns. If debtors is given the perpetual exclusive right to propose a plan, as in old chapter XI, the debtor will have significant leverage to coerce creditors into accepting its terms on a 'take-it-or-leave-it' basis. (...) Allowing the debtor to have permanent exclusivity thus could cause serious problems. However, Congress was concerned that the opposite rule, in which the debtor is given no exclusive right to file a plan, also would create significant difficulties. In short, a 'free for all' in filing would not be the palliative for all evils. One concern is that debtors would be reluctant to file chapter 11 in the first place if they knew that creditors could file hostile plans, and thus might forego an opportunity to reorganize and save the business until it was too late. Furthermore, even if the debtor did overcome that initial reluctance and file chapter 11, the absence of exclusivity might contribute to a breakdown of negotiations. Instead of sitting down at bargaining table and try to work things out, different groups might simply go off and file their own plan. Consensus might never be realized. Congress compromised, and sought to capture the best of both worlds. The solution was to give the debtor limited exclusivity. The balance struck in $\$ 1121$ is to give the debtor an initial exclusive period of 120 days to file a plan (and 180 days to obtain acceptances of that plan, $\$ 1121(c)(3)$, but thereafter to permit any party in interest to file a plan. $\$ 1121(b),(c)(2)$. In the interests of flexibility, the court is given the power, on a showing of cause, to extend (or contract) the debtor's exclusivity. Under this compromise, which gives the debtor the first chance to put an acceptable plan together, the debtor hopefully will not be deterred from filing for needed chapter 11 relief, and at the outset all parties will be forced to sit down together at the bargaining table. However, the debtor is not given the power to stall creditors into submission. (...) The congressional compromise has been honored in the breach. Courts routinely grant debtors multiple extensions of the exclusive period. Thus, in many cases a practice of de facto permanent debtor exclusivity had developed. This is not what Congress intended. (...) Many commentators have pointed out that indefinite exclusivity has been one of the biggest problems in chapter 11 practice under de Code, causing delay, driving up costs, and pressuring creditors into capitulating to unfavorable plans."
} 
Pois ao conceder ao devedor o direito perpétuo e exclusivo de propor o plano, como era no regime então vigente, o devedor possuía significativa vantagem para forçar os credores a aceitá-lo (na base do "pegar ou largar"). Por outro lado, a regra oposta, que retirava do devedor a exclusividade na apresentação do plano, também criava dificuldades significativas.

Uma preocupação era que o devedor ficasse relutante em pedir a reorganização se soubesse que seus credores poderiam apresentar planos contrários aos seus interesses (hostile plans), renunciando assim à oportunidade de sanear e recuperar o negócio até que fosse tarde demais. Além disso, ainda que o devedor conseguisse superar essa relutância inicial e requeresse a reorganização, a ausência de exclusividade poderia contribuir para o colapso das negociações. Em vez de se sentarem à mesa de negociações e tentar resolver as coisas, diferentes grupos poderiam simplesmente sair e apresentar os seus próprios planos, e o consenso talvez jamais fosse alcançado.

O Congresso americano procurou então captar o melhor dos dois mundos. A solução foi dar ao devedor uma exclusividade limitada. O equilíbrio alcançado consistiu em dar ao devedor um prazo inicial exclusivo de 120 dias para apresentar um plano (e 180 dias para obter sua aprovação pelos credores), mas a partir daí permitir que qualquer parte interessada apresentasse um plano alternativo, conferindo-se ao tribunal o poder de estender (ou reduzir) o prazo de exclusividade devedor, desde que demonstrada justa causa.

Com essa harmonização, que dá ao devedor a chance de primeiro apresentar um plano aceitável, tem-se a esperança de que o devedor não será dissuadido de requerer o necessário alívio da reorganização, e que desde o início todas as partes sejam obrigadas a sentarem-se juntas à mesa de negociações. Por outro lado, não é dado ao devedor o poder de enrolar os credores até que se submetam ao plano que oferecer.

TABB relata por fim que os tribunais têm rotineiramente concedido ao devedor múltiplas extensões do período de exclusividade, que na prática acabam tornando permanente algo que deveria ser limitado. Por isso, a indefinição quanto ao prazo de exclusividade é apontada por analistas como um dos maiores problemas do processo da reorganização, causando atrasos, elevando custos e pressionando os credores a se renderem a planos desfavoráveis. 
Eis aí um necessário e interessante contraponto: embora a flexibilidade seja importante para a eficiência do processo da reorganização, não pode dar margem a uma perpétua indefinição, capaz de romper com o equilíbrio das negociações.

\subsection{Direito do credor com garantia real de obstar a alienação do bem objeto da garantia ou a supressão desta}

Dispõe o art. 50, $\S 1^{\circ}$, da LRF que, se o plano de recuperação previr a alienação de bem objeto de garantia real, a supressão da garantia ou sua substituição somente serão admitidas mediante aprovação expressa do credor titular da respectiva garantia.

Logicamente, a aprovação exigida pela supressão ou substituição da garantia é somente do credor que a titulariza, e não de toda a classe de credores com garantia real, conforme já decidiu o Tribunal de Justiça de São Paulo ${ }^{118}$ :

"as garantias reais podem ser dispensadas pelos credores com elas beneficiados independentemente de concordância de outros credores da mesma devedora que nada tenham a ver com os créditos renunciados por seus concorrentes".

Para JORGE LOBO ${ }^{119}$, caso o credor se oponha à substituição da garantia, na hipótese de o plano prever a alienação de bem gravado, o “devedor poderá pleiteá-la judicialmente, desde que a substitua por imóvel, móvel ou semovente de valor equivalente e, até mesmo, por fiança idônea, que assegure, se e quando necessário, o recebimento do crédito”.

É até admissível que, reputando abusiva a recusa do credor na substituição de uma garantia real por outra, o juiz possa superá-la. Mas impelir ao credor uma fiança, com a devida vênia, parece ir além dos poderes do juiz, haja vista que as garantias pessoais se baseiam no princípio da confiança (e confiança não pode ser imposta).

\footnotetext{
${ }^{118}$ AI no 544.039-4/0-00, Rel. Des. Lino Machado; cf. FÁBIo UlhOA CoELHO. Comentários... Op. cit., p. 201.

${ }^{119}$ In: TOLEDO, Paulo F. C. Salles de Toledo [et. al.] (Coord.). Lei de Recuperação...Op. cit., p. 234. No mesmo sentido, endossando a posição de Jorge Jobo, confira-se MARIO SERGIO MILANI (Lei de recuperação judicial, recuperação extrajudicial e falência comentada. São Paulo: Malheiros, 2011, p. 228).
} 


\subsection{Direito ao tratamento isonômico na hipótese de "cram down"}

Em regra, o juiz concederá a recuperação judicial cujo plano não tenha sofrido objeção dos credores, ou tenha sido aprovado na assembleia-geral, por maioria de votos de todas as classes de credores (LRF, art. 58, caput). Porém, para o caso de não ser obtida a aprovação do plano por uma das três classes de credores, a lei prevê um quórum alternativo para a superação do veto da classe discordante (art. $58, \S 1^{\circ}$ ), hipótese em que o plano não poderá estabelecer tratamento diferenciado ${ }^{120}$ entre os credores da classe que o houver rejeitado (art. 58, $\S 2^{\circ}$ ).

\subsection{Direito de designar o gestor judicial em caso de afastamento do devedor}

A Lei $\mathrm{n}^{\circ} 11.101 / 2005$ adotou o sistema do debtor in possession, segundo o qual o devedor que requerer a recuperação judicial permanece conduzindo a atividade empresarial, sob a fiscalização do Comitê de Credores, se houver, e do administrador judicial (LRF, art. 64).

Porém, em casos excepcionais, de fraude, negligência ou grave incompetência administrativa, o devedor poderá ser afastado da administração da empresa pelo juiz, hipótese em que os credores, reunidos em assembleia-geral, deverão nomear um gestor judicial (LRF, art. 65).

Cuida-se de direito particularmente interessante aos credores, por permitir contornar a regra que condiciona a modificação do plano de recuperação à concordância do devedor: se o devedor for afastado, caberá ao gestor elaborar o plano de recuperação e submetê-lo à aprovação da AGC, ou mesmo aprovar modificações por ela propostas. Em nenhum dos casos, todavia, cogita-se da concordância do devedor, conforme assinala EDUARDO SECCHI MUNHOZ ${ }^{121}$ :

\footnotetext{
${ }^{120}$ Nos Estados Unidos, a inexistência de tratamento diferenciado entre os credores de uma mesma classe ou entre classes de mesma hierarquia (unfair discrimination) também é requisito para o cram down (Bankruptcy Code, $\S 1.129$, (b) 1).

${ }^{121}$ In: SOUZA JUNIOR, Francisco Satiro; PITOMBO, Antônio Sérgio de Moraes (Coords.). Comentários à Lei de Recuperação de Empresas e Falências. São Paulo: Revista dos Tribunais, 2005, p. 278.
} 
"É bem verdade que, na lei brasileira, o obstáculo à apresentação do plano representado pela vontade do devedor pode ser superado, na hipótese de ser determinado o seu afastamento pelo juiz, o que é admitido nas situações previstas no art. 64 (v.g., prática de crimes, fraude contra credores, atos irregulares de administração) (...). A interpretação sistemática do $\S 3^{\circ}$ do art. 56 e do art. 64 leva à conclusão de que, uma vez afastado o devedor, o plano modificado pela assembléia poderá ser aprovado se contar com a aprovação do gestor judicial, eleito pela própria assembléia geral de credores".

\subsection{Direito de exigir a decretação da falência}

A despeito do princípio da preservação da empresa, os credores não têm o dever de conceder a recuperação ao devedor ${ }^{122}$. Tanto assim que a lei lhes garante o direito de decidir por maioria acerca da aprovação do plano, bem como o direito de exigir a própria decretação da quebra.

Note-se que, segundo a sistemática adotada pela LRF, a vontade dos credores poderá ensejar a decretação da quebra tanto na hipótese de assim terem deliberado (art. 73, I) quanto no caso de haverem rejeitado o plano de recuperação (art. 73 , III):

Art. 73. O juiz decretará a falência durante o processo de recuperação judicial: I - por deliberação da assembléia-geral de credores, na forma do art. 42 desta Lei; (...) III - quando houver sido rejeitado o plano de recuperação, nos termos do $\S 40$ do art. 56 desta Lei;

Curioso observar que o quórum exigido para a aprovação da quebra e o quórum para aprovação do plano de recuperação não são os mesmos: enquanto a aprovação da quebra do devedor depende apenas dos votos favoráveis de credores que representem mais da metade do valor total dos créditos presentes à assembleia-geral, independentemente da classe que integram (art. 42), a aprovação do plano exige, em regra, a aprovação das três classes de credores, na forma do art. 58 (podendo-se superar a deliberação contrária de uma das classes, desde que atendidos outros requisitos). Essa questão será mais bem abordada no Capítulo III, item 9.

\footnotetext{
${ }^{122}$ O que não significa que, em alguns casos, sua discordância não possa ser considerada abusiva, conforme se verá no Capítulo IV.
} 
Além disso, a par do direito de deliberar a quebra do devedor, qualquer credor poderá denunciar ao juiz o descumprimento do plano de recuperação, exigindo assim a decretação da falência (LRF, art. 73, IV). E mesmo que o plano esteja sendo cumprido, nada impede o credor de requerer a falência por conta de obrigação que a ela não esteja sujeita aos efeitos da recuperação, ou mesmo pela prática de ato de falência (LRF, art. 73, parágrafo único).

\subsection{Direito de participar da Assembleia-Geral de Credores}

De um modo geral, assistem aos credores os direitos de assento, voz e voto na Assembleia-Geral de Credores, na qual são tomadas as principais decisões concernentes à empresa devedora, de acordo com as competências estabelecidas no art. 35 da LRF. A extensão desses direitos, bem como os limites e restrições a eles impostos serão tratados nos Capítulos III e IV, a seguir.

\subsection{Direitos dos credores na falência}

No processo de falência, os interesses dos credores dizem respeito à liquidação dos ativos do devedor, com a maximização ${ }^{123}$ do seu valor, ao pagamento dos seus créditos com a maior brevidade possível e ao respeito das suas garantias e da ordem de preferência legal. Os direitos que a lei lhes defere conformam-se com esses interesses.

A fim de garantir a eficiência do processo de liquidação, sem prejuízo das particularidades de cada negócio, concede-se aos credores o direito de determinar forma alternativa $^{124}$ de realização do ativo na falência, desde que obtida a aprovação dos titulares de dois terços dos créditos presentes na AGC (art. 46 c.c. art. 145).

\footnotetext{
${ }^{123}$ Conforme Euler Da CunHa PeiXoto: "O objetivo básico na realização do ativo é conseguir-se a sua maximização de forma a se obterem recursos suficientes para liquidação do passivo e, se possível, com sobra para o falido" (In: CORRÊA-LIMA, Osmar Brina; CORRÊA-LIMA, Sérgio Mourão. Comentários à Nova Lei de Falência e Recuperação de Empresas. Rio de Janeiro: Forense, 2009, p. 974).

${ }^{124}$ Daí que, "ao invés de optarem pela alienação de bens por leilão, propostas ou pregão, poderão deliberar a venda do ativo em bloco a um terceiro pré-determinado, a exemplo do que previa a lei revogada, ou mesmo a constituição de sociedade entre eles para dar continuidade aos negócios do falido, seja mediante a aquisição da empresa ou mesmo através de arrendamento" (RICARDO BERNADI. In: SOUZA JUNIOR, Francisco Satiro; PITOMBO, Antônio Sérgio de Moraes (Coords.). Comentários à Lei de Recuperação de Empresas e Falências. São Paulo: Revista dos Tribunais, 2005, p. 491).
} 
Além disso, os credores têm direito a que seja respeitada a ordem legal de pagamentos (LRF, art. 194). Com esse propósito, a lei busca vedar manobras fraudulentas tendentes a burlar esse direito, como, p.ex., a compensação ${ }^{125}$ dos créditos transferidos após a decretação da falência (salvo em caso de sucessão por fusão, incorporação, cisão ou morte) e dos créditos, ainda que vencidos anteriormente, transferidos quando já conhecido o estado de crise econômico-financeira do devedor ou cuja transferência se operou com fraude ou dolo (LRF, art. 122).

\subsubsection{Vantagens dos credores que financiam a recuperação}

Por trás de toda ideologia e princípios que cercam a recuperação da empresa, à margem de todas as construções acadêmicas e jurisprudenciais sobre os institutos da lei, há uma pergunta que não quer calar: quem paga a conta?

Um dos maiores pontos de estrangulamento da recuperação é, sem dúvida, o financiamento da empresa recuperanda. De nada adianta equacionar as dívidas passadas, prevendo dilações de prazo, remissões etc., ou mesmo forçar a aprovação do plano, se a empresa não contar com capital e insumos para continuar operando.

Na tentativa de minimizar esse problema, o art. 67, caput, da LRF prevê que os créditos decorrentes de obrigações contraídas pelo devedor durante a recuperação judicial, inclusive aqueles relativos a despesas com fornecedores de bens ou serviços e contratos de mútuo, serão considerados extraconcursais e, em caso de falência, serão pagos com prioridade sobre os demais créditos referidos no art. 83.

Além disso, o parágrafo único do art. 67 da LRF estabelece que os créditos quirografários sujeitos à recuperação judicial pertencentes a fornecedores de bens ou serviços que continuarem a provê-los normalmente após o pedido de recuperação judicial

${ }^{125}$ Conforme o art. 122, caput, da LRF, "compensam-se, com preferência sobre todos os demais credores, as dívidas do devedor vencidas até o dia da decretação da falência, provenha o vencimento da sentença de falência ou não, obedecidos os requisitos da legislação civil’. 
terão privilégio geral de recebimento em caso de decretação de falência, no limite do valor dos bens ou serviços fornecidos durante o período da recuperação.

Seria muito dizer, todavia, que tais dispositivos legais constituem propriamente um estímulo ao financiamento. São mais uma compensação pelo risco assumido pelos credores que se comprometem a suprir o devedor com os insumos necessários à continuidade do seu negócio.

Logicamente, portanto, a reclassificação que eles contemplam só atingem os créditos negociais, excluindo-se aqueles “não proveniente de negócio jurídico (crédito fiscal e parafiscal, multa administrativa, indenização por acidente de trabalho ou por qualquer outra razão etc.) porque os seus titulares não podem ser considerados colaboradores da recuperação" (FÁBIO UlHOA COELHO ${ }^{126}$ ).

\section{Deveres dos credores na recuperação judicial e na falência}

São poucos os deveres expressamente imputados aos credores pela LRF podendo ser citado, entre os raros exemplos, a obrigação de restituir em dobro as quantias recebidas por dolo ou má-fé (art. 152).

Também se imputam deveres aos credores no âmbito do Comitê (LRF, art. 27), ao qual a lei atribui, na recuperação judicial e na falência, as funções de: (i) fiscalizar as atividades e examinar as contas do administrador judicial; (ii) zelar pelo bom andamento do processo e pelo cumprimento da lei; (iii) comunicar ao juiz eventual violação dos direitos ou prejuízo aos interesses dos credores; (iv) apurar e emitir parecer sobre quaisquer reclamações dos interessados; (v) requerer ao juiz a convocação da assembleiageral de credores; e (vi) manifestar-se nas hipóteses previstas na lei.

\footnotetext{
${ }^{126}$ Comentários...Op. cit., p. 250. No mesmo sentido, confira-se SILVÂNIO COVAS: "a reclassificação atinge apenas os créditos negociais, de vez que o credor assume, por vontade própria, um risco associado à recuperação judicial" (In: DE LUCCA, Newton; e SIMÃO FILHO, Adalberto. Comentários à Nova Lei de Recuperação de Empresas e Falências. São Paulo: Quartier Latin, 2005, p. 322).
} 
Especificamente na recuperação judicial, também compete ao Comitê (i) fiscalizar a administração das atividades do devedor, apresentando, a cada trinta dias, relatório de sua situação, (ii) fiscalizar a execução do plano de recuperação judicial, e (iii) submeter à autorização do juiz, quando ocorrer o afastamento do devedor, a alienação de bens do ativo permanente, a constituição de ônus reais e outras garantias, bem como atos de endividamento necessários à continuação da atividade empresarial durante o período que antecede a aprovação do plano de recuperação judicial.

Ainda, nos termos do art. 32 da LRF, os membros do Comitê de Credores responderão pelos prejuízos causados à massa falida, ao devedor ou aos credores por dolo ou culpa.

De mais a mais, os deveres dos credores podem ser resumidos na obrigação de se pautarem segundo os princípios informadores da lei, que constituem baliza limitadora do exercício dos seus direitos (Código Civil, art. 197), sobretudo daqueles que lhe conferem a prerrogativa de ditar a solução à crise do devedor, ao deliberarem a aprovação do plano, a falência, a forma de liquidação etc. 
CAPÍTULO III - A ASSEMBLEIA-GERAL DE CREDORES 


\section{CAPÍTULO III - A ASSEMBLEIA-GERAL DE CREDORES}

\section{Conceito e natureza jurídica}

A partir do entendimento doutrinário dominante no País, pode-se definir a Assembleia-Geral de Credores como órgão colegiado, deliberativo, de funcionamento ocasional e hierarquicamente superior que, na recuperação judicial e na falência, manifesta a vontade coletiva da comunhão de credores, no âmbito da competência que lhe é atribuída pela lei ${ }^{127}$.

Segundo a teoria organicista, o conceito de órgão vem normalmente ligado à ideia de centro de imputação ${ }^{128}$, segundo a qual a vontade formada e manifestada pelo órgão é imputada à pessoa jurídica ao qual integra ${ }^{129}$. O órgão concentra, no âmbito de determinada estrutura, um conjunto de competências desempenhadas pelo indivíduo ou indivíduos que o compõem, mas que com eles não se confunde ${ }^{130}$. No exercício dessas competências, a manifestação da vontade pelos integrantes do órgão forma e expressa a da própria pessoa $^{131}$.

\footnotetext{
${ }^{127}$ Nesse sentido, confira-se a definição formulada por JORGE LOBO “A assembléia geral de credores é um órgão colegiado deliberativo, convocado e instalado na forma da lei, que tem a função de examinar, debater e decidir as matérias de sua atribuição exclusiva, discriminadas no art. 35, I e II, da LRF" (In: TOLEDO, Paulo F. C. Salles de Toledo [et. al.] (Coord.). Lei de Recuperação... Op. cit., p. 142). Confira-se, ainda, o conceito definido por ERASMO VALLADÃo FrANÇA: "A assembléia-geral de credores, na Lei no 11.101, é órgão que, na recuperação judicial e na falência, manifesta a vontade coletiva da comunhão de credores." "“Assembléiageral de credores". Revista do Advogado, São Paulo, n. 83, p. 42-43).

128 "Órgão é, portanto, o centro de imputação de poderes funcionais exercidos, por um ou mais indivíduos que nele estejam investidos, para formar e manifestar a vontade juridicamente imputável à pessoa jurídica". (MARCElo VieIRA VON ADAMEK. Responsabilidade civil dos administradores de S.A. São Paulo: Saraiva, 2009, p.11).

${ }^{129}$ Esse conceito é compartilhado pelo direito administrativo: "órgão é todo centro de competência, para desempenho de funções, através de um ou vários agentes, cuja atuação é sempre imputada à pessoa jurídica a que pertence" (HelY LOPES MeIRELles. Direito Administrativo Brasileiro. 36 ed. São Paulo: Malheiros: 2010, p. 69).

130 "O órgão pode ser integrado por uma ou mais pessoas, físicas ou jurídicas, mas ele não é a pessoa investida no cargo, e sim, concretamente, o próprio cargo ou centro de imputação de poderes funcionais. A pessoa investida da atribuição de exercer os respectivos poderes é apenas o seu titular ou membro (Organmietglied), verdadeiro suporte do órgão (Amtsträger, Organträger ou Organverwalter), porém sem com isso se confundir com o próprio órgão. (...) O seu titular não se confunde com o órgão em si; nem as modificações de seus membros, as mutações do substrato pessoal, modificam a configuração dos órgãos em si." (MARCELO VIEIRA VON ADAMEK. Idem, p. 12).

${ }^{131}$ DANIEL TRUFFAT salienta que “quando se 'vota' (insisto: como mera aplicação de um termo que carrega um alto componente simbólico) quem decide não é o votante, mas a congregação que integra. Assim a vontade da maioria dos votantes determina a decisão do corpo de que toma parte (...). Se o corpo colegiado é, por sua vez, órgão de um sujeito, tal decisão se atribui ao sujeito em questão". ("No existe em el derecho
} 
Tem-se defendido, porém, que a noção de órgão não é privativa dos entes personificados, podendo ser identificada no "indivíduo (ou grupo de indivíduos), enquanto age para o desenvolvimento de um interesse coletivo, ou seja, enquanto cumpre uma função de grupo" ${ }^{\prime 32}$. De acordo com MARCELO VIEIRA VON ADAMEK, a noção de órgão está vinculada geneticamente à de vontade social, constituindo decorrência lógica do conceito de interesse coletivo ${ }^{133}$.

A partir das lições de Carnelutti, Erasmo Valladẽo França sustenta que o interesse comum ou coletivo explica não somente a formação de qualquer grupo social, mas também a sua organização. O órgão, nesse contexto, seria o indivíduo ou indivíduos enquanto agem em favor desse interesse, cumprindo uma função do grupo. Conclui então que, sob a perspectiva funcional, "a noção de órgão não é incompatível com a comunhão, ainda quando esta seja entre nós despersonalizada. A massa subjetiva de credores, tanto na falência como na recuperação judicial, constitui comunhão de credores e, apesar de não ter personalidade jurídica, têm órgãos”. ${ }^{134}$

argentino nada que pueda denominarse 'derecho de voto' em lo referido a la solución concordataria". In: ARECHA, Martin (Coord.). El voto em las sociedades y los concursos. Buenos Aires: Legis Argentina, 2007, p. 239; tradução livre). No original: "Cuando se 'vota' (insisto: como mera aplicación de un término que porta un alto componente simbólico) quien decide no es el votante, sino la congregación que él integra. Así la voluntad mayoría de los votantes determina la decisión del cuerpo del que forman parte (...) Se el cuerpo colegiado es, a su vez, órgano de un sujeto, tal decisión se predica además del sujeto en cuestión.”.

Nesse mesmo sentido, rebatendo as críticas de Galgano (para quem não haveria decisão da própria pessoa jurídica, porque desprovida de vontade própria), assim se manifesta ERASMO VALLADÃo FrANÇA: "Conclui Galgano, pois, que a deliberação não representa a vontade da sociedade, ou da assembléia, mas sim a vontade da maioria (...) entretanto, se é procedente a crítica no sentido de que ela não pode expressar a 'vontade social', porque a pessoa jurídica não tem vontade, mas só o ser humano, é inegável, por outro lado, que a deliberação (da assembléia, ou da maioria, como quer Galgano) é imputável à sociedade, ou seja, a um outro sujeito de direito que não aos sócios que votaram. E tanto isso é verdade que, como já se observou, pelas deliberações responde a companhia - ela é a legitimada para eventual ação de anulação das deliberações, e não a assembléia ou maioria.

${ }^{132}$ ERASMO VAlladão FrançA. Invalidade das deliberações de assembléia das S/A. São Paulo: Malheiros, 1999, p. 29, conforme lição de CARNELUTTI, Sistema di diritto processuale civile, I, Pádua: Cedam, 1936, p. 12 , n. 3.

${ }^{133}$ Responsabilidade civil dos administradores de S.A. São Paulo: Saraiva, 2009, p. 12.

${ }^{134} \mathrm{O}$ mesmo autor ainda destaca que "a possibilidade da existência de órgãos também nas comunhões, e não apenas nas sociedades e associações, é admitida, em sede doutrinária, entre outros, por jurista da mais alta expressão: v. ROMANO, Santo. Frammenti di um dizionario giuridico, no verbete Organi, p. 153. In: SOUZA JUNIOR, Francisco Satiro; PITOMBO, Antônio Sérgio de Moraes (Coords.). Comentários à Lei de Recuperação de Empresas e Falências. São Paulo: Revista dos Tribunais, 2005, p. 187. 
Nessa ordem de ideias, ÁlvARO MARIANO ${ }^{135}$ esclarece que a existência do órgão pressupõe um complexo sistemático de interesses, unificados em razão de fins específicos, e que congrega para seu atendimento um universo de atividades-meio (das quais uma parcela será imputada ao órgão). É dessa unificação coordenada de interesses destinada a atender a uma determinada coletividade - que surge o órgão, sem demandar, necessariamente, a existência de uma personalidade jurídica:

“O órgão, portanto, é um expediente jurídico existente não apenas nas pessoas jurídicas, mas em outras coletividades não-personificadas, aos quais se atribui o desempenho de certas atividades com vistas ao atendimento à finalidade mediata que precisamente fundamenta a formação e a manutenção da dita coletividade, personificada ou não. Nessa ordem de ideias, não parece difícil aceitar a existência de órgãos também nos processos concursais, à semelhança do que sucede nas pessoas jurídicas - entre as quais as sociedades e, entre estas, por sua vez, especialmente, as companhias, que contêm o modelo mais complexo de arranjo orgânico."

Assim é que a teoria do órgão tem servido à recuperação judicial e à falência para explicar o modo como se forma a vontade da coletividade de credores (e por que, no processo de formação dessa vontade, a decisão da maioria sujeita a minoria), atribuindo-se a vontade definida na Assembleia à massa falida subjetiva, assim entendida como a comunhão de interesse dos credores ${ }^{136}$.

${ }^{135}$ Abuso de voto na recuperação judicial. Tese de doutoramento, São Paulo: Faculdade de Direito da USP, 2011, p. 77.

136 "Advirta-se, contudo, que a chamada natureza jurídica da coletividade dos credores, na falência - a chamada "massa falida subjetiva" - é questão deveras controvertida. Há quem diga, com base na doutrina francesa mais antiga, que se trataria de um estado de associação (nesse sentido, LACERDA, J.C. Sampaio de. Manual de direito falimentar, p. 173), o que parece inaceitável, sobretudo se se considerar que a associação é uma união - voluntária, por certo - de pessoas que se organizam para fins não econômicos (art. 53 do CC). De sociedade igualmente não se cuida, faltando, entre outros, o elemento da voluntariedade. (..) A idéia de que se cuidaria de uma universalidade de direito, sustentada por alguns autores (v. REQUIÃO, Rubens. Curso de direito falimentar, p. 160), também soa inaceitável, eis que, sendo esta conceituada como "o complexo de relações jurídicas, de uma pessoa, dotadas de valor econômico" (art. 91 do CC), não se concebe que a universalidade possa ser confundida com as próprias pessoas - que são os credores. A universalidade, com efeito, é classificada como bem coletivo (Parte Geral, Livro II, Título Único, Capítulo I, Seção V - "Dos bens singulares e coletivos" - do CC), e, nesse sentido, identifica-se com a massa falida objetiva (cf. MIRANDA, Pontes de. ..). A hipótese de se tratar de uma comunhão sobre os bens do devedor também é afastada, eis que "sujeito dos direitos sobre os bens do patrimônio continua o devedor falido. Não os perdeu. $\mathrm{O}$ que se lhe retirou foi o poder de dispor com eficácia contra os credores (idem, ibidem, $\S 3.318$, n. 1, p. 161; v., ainda, § 3.347, n. 1, p. 279). Trajano de Miranda Valverde também refuta veementemente a hipótese de comunhão inclusive por entender que cada credor "age no seu próprio interesse, contrariando, se possível, o dos outros concorrentes" (VALVERDE, Trajano de Miranda. Comentários à Lei de Falências, v. 1, n.256, p. 257-258). É certo, porém, que, a par dos interesses individuais, pode haver também, tanto na recuperação, como na falência, interesses coletivos ou comuns dos credores, como se aponta a seguir no texto. É lícito falar, assim, em uma comunhão de interesses entre os credores." (ERASMO VALLADÃo FranÇA. In: SOUZA 
Nesse sentido, a doutrina nacional ${ }^{137}$ é unânime ao tratar a AGC como órgão ${ }^{138}$, muito embora se desconheça outros autores, além dos citados acima, que tenham efetivamente analisado a sua natureza jurídica ${ }^{139}$.

A despeito da unanimidade nacional ${ }^{140}$, o entendimento não é isento de críticas. Edgardo DANIEL TRUfFAT ${ }^{141}$, Professor da Universidade de Buenos Aires, questiona a própria existência de um 'interesse coletivo' dos credores. Culpa a doutrina societária pela adoção (a seu ver equivocada) da teoria do órgão para explicar a natureza da assembleia de credores, que buscou na assembleia de sócios um paradigma para explicar o instituto do direito concursal.

Para ele, no entanto, não seria possível equiparar os dois institutos porque enquanto os votos proferidos pelos sócios servem para formar a decisão do ente societário, a partir do interesse coletivo que existe em torno dela, na assembleia concursal os credores não exercem propriamente o direito de "voto", mas simplesmente externam a vontade individual de se submeterem ou não à proposta do devedor, do que não decorre a formação de uma "vontade coletiva", como há na sociedade:

JUNIOR, Francisco Satiro; PITOMBO, Antônio Sérgio de Moraes (Coords.). Comentários à Lei de Recuperação de Empresas e Falências. São Paulo: Revista dos Tribunais, 2005, p. 187-188).

${ }^{137}$ Leia-se: a doutrina nacional construída depois da edição da Lei no 11.101/2005.

${ }^{138}$ Nesse sentido se posicionam JORGE LOBo (Comentários... Op. cit., p. 35), MANOEL JUSTINO BEZERRA FiLHo. Nova lei de recuperação e falências comentada. 3 ed. São Paulo: Revista dos Tribunais, 2005, p. 110, SÉRGiO CAMPINHO (Falência e recuperação de empresa. Rio de Janeiro: Renovar, 2006, p. 45-46), JAIRO SADDI ("Assembléia de credores: um ano de experiência na nova Lei de Falências. Uma avaliação". Revista de Direito Bancário e do Mercado de Capitais, São Paulo, n. 37, p. 126); MARLON TOMAZETTE (Curso de Direito Empresarial. São Paulo: Atlas, 2011, v. 3, p. 131); Vera Helena E Mello FranCo e RaChel SzTAJN (Falência e Recuperação da Empresa em Crise. Rio de Janeiro: Elsevier, 2008, p. 79), entre muitos outros.

${ }^{139}$ Chega a ser surpreendente a inexistência de questionamentos, no Brasil, sobre a natureza da assembleia de credores, especialmente se levarmos em conta que a matéria é debatida até hoje pela doutrina italiana, normalmente a primeira a ser consultada pelos nossos comercialistas.

${ }^{140} \mathrm{Na}$ Itália, cuida-se de questão controvertida. Admitindo a natureza de órgão da assembleia de credores, confira-se RenZo Provinciali (Trattato di diritto fallimentare. Milão: Giuffrè, 1974, p. 2218), AURELIO CANDIAN (Il processo de concordato preventivo. Pádova: Antonio Milani, 1937, p. 83). Em sentido contrário, vide UMBERTO AZZOLINA (Il fallimento e le altre procedure concorsuali. 2 ed. Torino: UTET, 1961, p. 1522). Comentando acerca da divergência da doutrina italiana, confira-se GIOVANNI LO CASCIO (Il concordato preventivo. Milão: Giuffrè, 2011).

141 'No existe en el derecho argentino nada que pueda denominarse 'derecho de voto' en lo referido a la solución concordataria”. In: ARECHA, Martin (Coord.). El voto en las sociedades y los concursos. Buenos Aires: Legis Argentina, 2007, p. 233-250. 
"hoje não se vota nos concursos, nem se votava na assembleia de credores $^{142}$ (apenas se dava um enquadramento formal - quase teatral - à manifestação de vontade dos credores de aceitar ou rejeitar, cada um deles, um a um, a proposta do devedor. (...) Discutir sobre o direito de voto é, portanto, (i) um encantador anacronismo (que tem, ademais, a vantagem da simplicidade verbal - é mais fácil de dizer, por exemplo, 'exclusão de voto' que 'exclusão da base de cômputo de maiorias'), ou (ii) uma opção ideológica. (...) Não há - em verdade jamais houve - um sujeito distinto dos credores que, instituído na assembleia, atuará como órgão de um consórcio acidental e forçado destes. O que existe são credores concorrente habilitados a expressar sua aprovação ou rejeição em relação à proposta e que formam parte da base de cálculo das maiorias."143.

À época do Decreto n ${ }^{\circ} 5.746 / 1929$, comentado no item 2.4 do Capítulo I desta

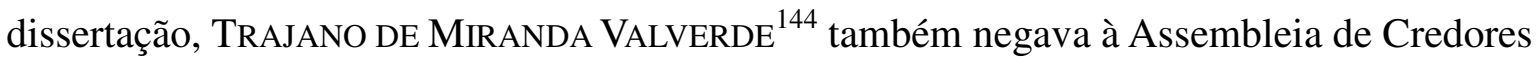
a natureza de órgão, por discordar das abstrações em torno da massa subjetiva que tentam aproximá-la de um ente personificado:

"Diz-se que a assembleia dos credores é o órgão da massa dos credores. Para os que personificam a massa subjetiva, ou dizem que ela, em certos casos, como tal se comporta, ou, ainda, para os que consideram o patrimônio unificado do falido uma pessoa jurídica, a expressão 'órgão' tem um valor especial, é o aparelho que exterioriza a vontade da pessoa jurídica ou a dos credores, na sua unidade. Para os que, como nós, rejeitamos essa abstração, a palavra 'órgão', de uso corrente e cômodo, não significa senão a pessoa ou as pessoas, às quais a lei atribui certas funções na organização da falência. A assembleia de credores, isto é, os credores reunidos em determinadas condições, dá-lhes a lei atribuições, que eles as exercem consoante as prescrições da própria lei, delas não podendo afastar-se nas deliberações que tomarem, as quais, como em todas as assembléias, exprimem a vontade presumida da maioria"

\footnotetext{
${ }^{142}$ No regime concursal argentino atual, já não é convocada a Assembleia-Geral de Credores (ou Junta) para deliberar sobre a proposta do devedor. $\mathrm{Na}$ verdade, este possui um prazo para colher dos credores que representem determinado quórum a manifestação da sua concordância com o acordo proposto.

143 DANIEL TRUFFAT ("No existe en el derecho argentino nada que pueda denominarse 'derecho de voto'... Op.cit., p. 241 e 243; tradução livre). No original: "No se vota hoy en los concursos, ni se votaba en la Junta (apenas se daba un marco formal - casi teatral - a la expresión de los acreedores de aceptar o rechazar - cada uno de ellos y por y para cada uno de ellos - la propuesta del debitor). (...) Discutir sobre el derecho de voto es, por tanto, (i) un encantador anacronismo (que tiene, además, la ventaja de la simplicidad verbal - es más fácil decir por ejemplo, 'exclusión de voto' que 'exclusión de la base de cómputo de mayorías'), o (ii) una opción ideológica. (...) No hay - en verdad jamás hubo - un sujeto distinto de los acreedores que instituido en 'Junta' actuara como órgano de un consorcio accidental y forzoso de estos. Lo que hay son acreedores concurrentes habilitados para expresar su aprobación/rechazo respecto de la propuesta y que forman parte de la base de cómputo de las mayorías."
}

${ }^{144}$ A Falencia no Direito Brasileiro. Rio de Janeiro: Ariel, 1932, v. 2, p. 47. 
O mestre rejeitava a própria ideia de comunhão de credores ${ }^{145}$, ressaltando que o concurso entre eles não passa de um processo legal, involuntário, em que "cada um age por si e no seu próprio interesse, contrariando, se possível, o dos outros concorrentes" Não haveria, assim, a formação de uma vontade coletiva, consistindo a deliberação num processo para resolver os conflitos de interesses entre os credores.

Esse modo de pensar encontra eco nas lições de FRANCESO GALGANO ${ }^{147}$, para quem a decisão decorrente de um processo deliberativo não resulta, necessariamente, na expressão de uma vontade coletiva:

\begin{abstract}
"Este excursus sobre o modo de formação das deliberações conduz a uma dúplice conclusão: a) Existem razões mais que suficientes para excluir a vigência, no nosso sistema, de um princípio geral que imponha a formação colegial das deliberações. O método colegial se refere ao modo de funcionamento de determinadas organizações coletivas e, em primeiro lugar, das sociedades capitalistas; não diz respeito ao modo de expressar determinados atos jurídicos, como o voto e a deliberação; $b$ ) Resulta carente de base normativa a teoria tradicional que qualifica a deliberação como ato colegial, expressão de uma vontade coletiva, e a contrapõe tanto ao contrato quanto ao ato unilateral. A colegialidade se refere às internas e variadas formas de organização dos entes coletivos; a deliberação, separada do procedimento - às vezes livre, às vezes vinculado a uma modalidade
\end{abstract}

\footnotetext{
145 “Acreditamos haver demonstrado ... que os credores concorrentes não formam nenhuma comunhão, nem tampouco constitui a coletividade deles uma pessoa jurídica." (A Fallencia no Direito Brasileiro. Rio de Janeiro: Ariel, 1934, v. 3, p. 17).

146 “O concurso de credores é um processo legal. Não é possível ver-se nessa concorrência uma associação, embora momentânea, de indivíduos, ou mesmo uma communio incidens, ou qualquer outra espécie de comunhão. (É um termo que também deve ser afastado por gerar ideias erradas sobre o concurso de credores). Cada credor, que no concurso resolve entrar, sabe de antemão quais são os seus direitos e quais as suas obrigações; o que pode e o que não pode fazer. Cada um age por si e no seu próprio interesse, contrariando, se possível, o dos outros concorrentes. Nenhum espírito associativo, mas o conflito de interesses, que a lei procura solucionar, ora pondo de lado os interessados, ora consultando-os pela voz da maioria" (A Falencia no Direito Brasileiro. Rio de Janeiro: Ariel, 1931, v. 1, p. 146).

${ }^{147}$ Trattato di diritto civile. Milão: Cedam, 2010, v. 3, p. 30, tradução livre. No original: “Questo excursus sui modi formazione delle deliberazioni conduce ad una duplice conclusione: a) esistono elementi di giudizio piú che sufficienti per escludere la vigenza, nel nostro sistema, di un generale principio che impogna la formazione collegiale delle deliberazioni. Il metodo collegiale attiene al modo di operare di determinate organizzazioni collettive e, in primo luogo, delle società di capitali; non attiene al modo di espressione di determinati atti giuridici, quali il voto e la deliberazione; b) risulta priva di basi normative la tradizionale teoria che qualifica la deliberazione come atto collegiale, esprimente una volontà collettiva, e la contrappone tanto al contratto quanto all'atto unilaterale. La collegialità attiene alle interne e varie forme di organizzazione degli enti collettivi; la deliberazione, separata dai procedimenti - a volte liberti, a volte vinvolati a modalità rigorose - secondo i quali è formata, in altro non consiste se non nella pluralità dei voti che concorrono a formala, i quali sono altrettanti atti unilaterali fra vivi aventi contenunto patrimoniale, cui sono applicabili, ai sensi dell'art. 1324, le norme sui contratti, in quando compatibili con il loro carattere unilaterale."
} 
rigorosa - segundo o qual é formada, não consiste senão na pluralidade dos votos que concorrem para formá-la, que são igualmente atos unilateriais inter vivos com conteúdo patrimonial, aos quais são aplicáveis, nos termos do art. 1324, as regras dos contratos, no que compatíveis com o seu caráter unilateral."

Sem a pretensão de apresentar solução para a controvérsia, permitimo-nos fazer algumas ponderações que mereceriam, parece-nos, alguma atenção da doutrina nacional, ainda que para reafirmar a natureza que vem sendo atribuída (sem nenhuma hesitação) à Assembleia-Geral de Credores.

Pois bem. A teoria do órgão, em seu núcleo fundamental, serve para imputar uma decisão tomada por pessoas naturais (direta ou indiretamente) a uma entidade jurídica, normalmente personificada, mas nem sempre ${ }^{148}$. Não por outra razão, os órgãos são definidos como "centros de imputação".

Para explicar como uma entidade jurídica manifesta vontade (para contratar, assumir obrigações etc.), vale-se do recurso da imputação: imputa-se a ela a vontade definida por indivíduo ou indivíduos que se arregimentam nos seus órgãos. Assim, p. ex., imputa-se à sociedade anônima a vontade formada, através do método colegial, no âmbito da Assembleia-Geral de Sócios, por isso considerada órgão da entidade.

Aplicando-se o mesmo conceito ao direito concursal, à falta de entidade personificada, a doutrina admite que a Assembleia seria um órgão da massa subjetiva de credores, formado a partir da comunhão dos seus interesses. Sem entrar no mérito da discussão se haveria ou não tal "comunhão de interesses" "149, indaga-se a quem seriam imputadas as decisões da Assembleia de Credores. À massa subjetiva? Aos próprios credores?

A "massa", enquanto entidade abstrata e mera comunhão de interesses, não é um sujeito de direito. Ela própria não assume, na aprovação do plano, nenhum direito ou obrigação. Por outro lado, conquanto a aprovação do plano de recuperação, depois de homologada, tenha o condão de interferir na esfera jurídica dos credores, mesmo que

\footnotetext{
${ }^{148}$ P.ex., um condomínio edilício.

${ }^{149}$ Conceito rejeitado, entre outros, por TRAJANO DE MIRANDA VALVERDE (vide nota de rodapé ${ }^{\circ}{ }^{146}$ ).
} 
dissidentes ou ausentes, nem por isso se lhes pode imputar a vontade da maioria ${ }^{150}$, ainda que se vinculem à resolução por esta determinada.

De modo que se volta a questionar: as decisões da AGC são imputadas a alguém? E mais: há necessidade de recorrer-se à figura da imputação para explicar os efeitos das decisões da AGC sobre os credores? E, se não há imputação, faz sentido adotar a teoria do órgão para explicar a natureza da assembleia?

Eis algumas questões que ainda demandam resposta, da mesma forma que carece de explicação doutrinária o mecanismo pelo qual, no âmbito da recuperação extrajudicial, o acordo entre o devedor e parte dos credores vincula todos os integrantes de uma determinada classe, mesmo sem a realização de assembleia (LRF, arts. 163 e 164).

\subsection{Classificação e características}

Passa-se à classificação da Assembleia-Geral de Credores, a partir da sua concepção enquanto órgão, que é a prevalecente na doutrina.

Tem-se, assim que: (i) quanto à estrutura, tanto pode ser um órgão unitário (quando constituído por apenas um centro de competência) ou composto, quando houver a instalação do Comitê de Credores, órgão dotado de funções auxiliares (de fiscalização, consulta etc.) ${ }^{151}$; (ii) quanto ao número de membros, é um órgão plural, vez que admite mais de um titular ${ }^{152}$; e (iii) quanto à sua atuação funcional, cuida-se de órgão colegiado ${ }^{153}$, que atua e decide pela manifestação conjunta e majoritária de seus integrantes.

\footnotetext{
${ }^{150}$ Isso não acontece nem na sociedade. Conquanto a decisão da maioria dos sócios vincule os demais, sujeitando-os juridicamente, isso não quer dizer que se impute a eles vontade alguma; a vontade será sempre imputada ao ente.

151 “O que tipifica o órgão como simples ou unitário é a inexistência de outro órgão incrustado na sua estrutura, para realizar desconcentradamente sua função principal ou para auxiliar seu desempenho. (...) Órgãos compostos são os que reúnem na sua estrutura outros órgãos menores, com função principal idêntica (atividade-fim realizada de maneira desconcentrada) ou com funções auxiliares diversificadas (atividadesmeios) atribuídas a órgãos menores)”. (HELY LOPES MEIRELLES. Direito Administrativo .... Op.cit., p. 73).

152 “...de acordo com o número de titulares, os órgãos classificam-se em órgãos singulares, compostos por um titular, e órgãos plurais, com dois ou mais titulares”. (MARCELO VIEIRA VON ADAMEK. Responsabilidade civil ...Op. cit., p. 13).

153 "Nos órgãos colegiados não prevalece a vontade individual de seu Chefe ou Presidente, nem a de seus integrantes isoladamente: o que se impõe e vale juridicamente é a decisão da maioria, expressa na forma legal, regimental ou estatutária”. (HELY LOPES MEIRELLES. Direito Administrativo .... Op.cit., p. 74)
} 
Além disso, a ACG constitui órgão hierarquicamente ${ }^{154}$ superior $^{155}$, porquanto dotado da competência de constituir dois outros órgãos: o Comitê de Credores ${ }^{156} 157$ e o gestor judicial $^{158}$. Atribui-se-lhe, ainda, o caráter deliberativo, porque forma e expressa a vontade coletiva dos credores através das suas deliberações, exercendo, assim, poder função deliberante, conforme ensina ERASMO VALLADÃo FRANÇA ${ }^{159}$.

Por fim, ressalta-se que, embora a AGC seja um órgão obrigatório ${ }^{160}$, poderá jamais funcionar. Nem mesmo a concessão da recuperação depende da convocação da AGC, no caso de nenhum credor formular objeção ao plano (LRF, art. 58, caput). Assim, se não ocorrer nenhuma das causas legais que ensejam a instalação do órgão, o processo de insolvência pode ter início e fim sem que nunca a AGC seja convocada.

Alguns autores afirmam, por conta disso, que a AGC não seria um órgão obrigatório $^{161}$. Discorda-se de tal posição porque a lei não permite a exclusão do órgão: ele sempre existirá, ainda que por vezes não seja chamado a trabalhar. Mais correto dizer, portanto, que o seu funcionamento não é sempre obrigatório, como ensinam VERA HELENA E Mello Franco e RACHEL SZTAJN ${ }^{162}$.

\footnotetext{
${ }^{154}$ Negando a existência de hierarquia, assim se manifesta MARIO SERGIO MILANI: “...não vislumbramos na lei sob comento uma hierarquia propriamente dita entre juiz, assembléia-geral de credores, comitê de credores e administrador judicial. O que ocorre é que para cada um desses órgãos o legislador fixou um feixe de atribuições que deve ser respeitado". (Lei de recuperação judicial...O. cit., p. 169).

${ }^{155}$ Cf. ERASMo VAlladẽo FrançA. “Assembléia-geral de credores”. Revista do Advogado, São Paulo, n. 83, p. 43. Ressalva-se, porém, que há algumas variações nas classificações dos órgãos quanto à hierarquia. Segundo algumas classificações, a AGC poderia ser tida como um órgão independente ou autônomo.

${ }^{156}$ Lei no 11.101/2005, art. 26 c.c. art. 35, I, "b", e II, "b”.

157 "Se se pudesse falar aqui em hierarquia, seria possível dizer que a assembléia-geral seria o órgão superior em relação ao Comitê de Credores”. (MANOEL JuSTINO BEZERRA FILHO. Nova lei de recuperação e falências comentada. 3 ed. São Paulo: Revista dos Tribunais, 2005, p. 110)

${ }^{158}$ Lei $\mathrm{n}^{\mathrm{o}} 11.101 / 2005$, art. 65 c.c. art. 35, I, “e”.

${ }^{159}$ In: SOUZA JUNIOR, Francisco Satiro; PITOMBO, Antônio Sérgio de Moraes (Coords.). Comentários à Lei de Recuperação de Empresas e Falências. São Paulo: Revista dos Tribunais, 2005, p. 188.

160 "Para nós a assembléia-geral de credores é obrigatória, tanto no âmbito da recuperação judicial, quanto no campo da falência, exceto em uma hipótese”. (MARIO SERGIO MILANI. Lei de recuperação judicial...O. cit., p. 169).

${ }^{161}$ V.g., MARLON TOMAZETTE: "tal órgão é facultativo, na medida em que nem sempre será necessária essa manifestação dos credores” (Curso de Direito Empresarial. São Paulo: Atlas, 2011, v. 3, p. 131); e Jorge Lobo: "A assembleia geral de credores é um órgão colegiado não obrigatório" (In: Lei de recuperação...Op. cit., p. 143).

${ }^{162}$ Falência e Recuperação da Empresa em Crise. Rio de Janeiro: Elsevier, 2008, p. 79.
} 
Por outro lado, conquanto o funcionamento da AGC não seja sempre obrigatório, é inconveniente atribuir-lhe funcionamento facultativo, como fazem alguns doutrinadores $^{163}$. "Faculdade" exprime opção, vontade, direito ou poder de fazer ou não alguma coisa ${ }^{164}$, sendo certo que há pelo menos uma hipótese em que a AGC será obrigatoriamente convocada independentemente da vontade de quem quer que seja, isto é, no caso de afastamento do devedor, para a indicação do gestor judicial. Por isso, em termos gerais, parece ser mais preciso afirmar que a AGC é um órgão de funcionamento ocasional, às vezes facultativo, às vezes obrigatório.

Ainda, discorda-se de ERASMO VALlADÃo FrANÇA ${ }^{165}$ quando afirma, peremptoriamente, sem nenhuma ressalva, que "não há convocação da Assembléia de credores na recuperação judicial de microempresas ou empresas de pequeno porte, em que o devedor opte pelo plano especial previsto nos art. 70 a $72 \%$. Na verdade, a Lei $\mathrm{n}^{\circ}$ 11.101/2005 não excluiu a AGC da recuperação especial para a micro e pequena empresa. Ela apenas determinou que a AGC não será convocada para deliberar sobre o plano de recuperação (art. 72) ${ }^{166}$, daí não decorrendo, porém, que a AGC não será instalada em nenhuma das demais hipóteses legais (p. ex., para a indicação do nome do gestor judicial em caso de afastamento do devedor).

163 V.g., ERASMO VAlladẽo FranÇA: "A Assembléia-geral de Credores é órgão de funcionamento facultativo" (In: Comentários...Op.cit., p. 189). Essa definição não é errada, pois uma das acepções do adjetivo "facultativo" consiste, justamente, naquilo que não é obrigatório. Mas o adjetivo traz também consigo uma carga de voluntariedade, que não é conveniente para caracterizar o órgão em termos gerais: pois se haverá casos em que o funcionamento da AGC será realmente dependente da vontade dos credores (p. ex., caso algum deles manifeste objeção ao plano de recuperação), em outros sua convocação é imposta independentemente do exercício de qualquer faculdade, como se dá para a indicação do gestor judicial, em caso de afastamento do devedor.

164 Cf. Antônio HouAiss. Dicionário Houaiss da Língua Portuguesa. Rio de Janeiro: Objetiva, 2001, p. 1299.

${ }^{165}$ In: Comentários...Op.cit., p. No mesmo sentido se manifesta JoÃo BosCO CASCARDO DE GOUVÊA: "Na recuperação judicial das micro e empresas de pequeno porte inexistirá assembléia quando os devedores resolverem postulá-la mediante a segunda subespécie, a de rito especial (art. 72, caput)". (Recuperação e Falência. Rio de Janeiro: Forense, 2009. p. 71). Incorre no mesmo equívoco, s.m.j., CARLOS KLEIN ZANINI (In: SOUZA JÚNIOR, Francisco Satiro de; PITOMBO, Antônio Sérgio de Moraes (Coords.). Comentários à Lei de Recuperação de Empresas e Falência. São Paulo: Revista dos Tribunais, 2005, p. 326)

${ }^{166}$ Art. 72. Caso o devedor de que trata o art. 70 desta Lei opte pelo pedido de recuperação judicial com base no plano especial disciplinado nesta Seção, não será convocada assembléia-geral de credores para deliberar sobre o plano, e o juiz concederá a recuperação judicial se atendidas as demais exigências desta Lei. 


\section{Composição}

Segundo a doutrina dominante, a AGC é órgão da recuperação judicial e da falência que se forma a partir do interesse coletivo dos credores. Porém, não são todos os credores do devedor que compõem a Assembleia-Geral, conforme se verá a seguir.

\subsection{Na recuperação judicial}

Na recuperação judicial, a AGC será composta, em regra, pelos titulares dos créditos existentes na data do pedido, ainda que não vencidos (LRF, art. 49, caput).

Contudo, não fazem parte da AGC os credores de obrigações contraídas a título gratuito e das despesas feitas para tomar parte do processo, porque declaradas inexigíveis no âmbito da recuperação judicial (LRF, art. $5^{\circ}$, I, da LRF).

Além destes, também não integram a $\mathrm{AGC}$, ao menos em princípio ${ }^{167}$, os credores excluídos dos efeitos da recuperação, quais sejam: (i) os titulares de créditos constituídos depois do pedido de recuperação (LRF, art. 49, caput); (ii) os credores de dívidas fiscais $^{168}\left(\mathrm{LRF}\right.$, arts. $6^{\circ}, \S 7^{\circ}, 57$ e 68, e CTN, art. 187); (iii) os credores titulares da posição de proprietário fiduciário de bens móveis ou imóveis, arrendador mercantil, o proprietário ou promitente vendedor de imóvel cujos respectivos contratos contenham cláusula de irrevogabilidade ou irretratabilidade, inclusive em incorporações imobiliárias, e proprietário em contrato de venda com reserva de domínio (LRF, art. 49, § $3^{\circ}$ ); (iv) os

\footnotetext{
${ }^{167}$ Conforme visto no Capítulo II, item 2.1, não há impedimento a que determinados credores excluídos dos efeitos da recuperação se sujeitem voluntariamente ao plano.

${ }^{168}$ A propósito do tema, vale conferir a crítica feita à não-submissão dos débitos físcais aos efeitos da recuperação judicial, especialmente porque, ainda hoje, não existe lei específica sobre o parcelamento dos tributos: "O problema retratado no dispositivo legal em comento tem sede na ausência da submissão da Fazenda Pública ao sistema de recuperação de empresas. O parcelamento do crédito tributário será a alternativa para o cumprimento da exigência, possibilitando a juntada de certidões 'positivas com efeitos negativos' (...). É lamentável a ausência, até o presente momento, de lei específica dispondo sobre o parcelamento dos débitos tributários. O Poder Público, um dos maiores responsáveis pela atenção à função social da empresa, deveria ser o primeiro a incentivar o parcelamento de tais débitos, sob pena de todo o processo de recuperação ser engendrado, com a apresentação do plano e sua aprovação, cair por terra pelo fato da falta com os cofres públicos." (MÁRCIO GUIMARÃES. In: CORRÊA-LIMA, Osmar Brina; e LIMA, Sérgio Mourão Correa (coord.). Comentários à nova Lei de Falência e Recuperação de Empresa. Rio de Janeiro: Forense, 2009, p. 395).
} 
titulares de créditos decorrentes de adiantamento a contrato de câmbio para exportação ${ }^{169}$ (LRF, art. $49, \S 4^{\circ}$ c.c. art. 86, II) e de obrigações assumidas no âmbito das câmaras ou prestadoras de serviços de compensação e de liquidação financeira (LRF, art. 193).

Com exceção desses credores, todos os demais integram a Assembleia-Geral, embora só sejam admitidos a participar do conclave aqueles que tenham a sua condição de credores reconhecida no processo, segundo a fase em que se encontra, conforme estabelece o art. 39, caput, da LRF:

Art. 39. Terão direito a voto na assembléia-geral as pessoas arroladas no quadro-geral de credores ou, na sua falta, na relação de credores apresentada pelo administrador judicial na forma do art. $7^{\circ}, \S 2^{\circ}$, desta Lei, ou, ainda, na falta desta, na relação apresentada pelo próprio devedor nos termos dos arts. 51, incisos III e IV do caput, 99, inciso III do caput, ou 105, inciso II do caput, desta Lei, acrescidas, em qualquer caso, das que estejam habilitadas na data da realização da assembléia ou que tenham créditos admitidos ou alterados por decisão judicial, inclusive as que tenham obtido reserva de importâncias, observado o disposto nos $\S \S 1^{\circ}$ e $2^{\circ}$ do art. 10 desta Lei.

Diante das várias remissões ${ }^{170}$ feitas pelo dispositivo legal transcrito acima (que dificultam a sua imediata compreensão), convém explicá-lo em detalhes.

Como regra geral, só será admitido na Assembleia quem tenha sido arrolado no quadro-geral de credores $^{171}$, documento consolidado a partir da relação de credores elaborada pelo administrador judicial na forma do art. $7^{\circ}, \S 2^{\circ}$, da LRF e das decisões

\footnotetext{
${ }^{169}$ No adiantamento a contrato de câmbio para exportação, ou ACC, o exportador, após contratar a venda de seu produto ao Exterior, procura o agente de câmbio, obtendo em moeda nacional o valor que receberia, após a entrega do produto. Entregue o produto no Exterior, o importador paga diretamente ao banco, liquidando-se a operação. Caso o exportador não entregue o produto e sua falência seja decretada, o banco pode pedir a restituição da importância adiantada (LÍDIA VALÉRIO MARZAGÃO. “A recuperação judicial” In: MACHADO, Rubens Approbato (coord.). Comentários à nova lei de falências e recuperação de empresas. São Paulo: Quartier Latin, 2007, p. 89).

${ }^{170}$ Aliás, o excessivo número de remissões é uma constante da Lei ${ }^{\circ}{ }^{\circ} 11.101 / 2005$, criticado pela doutrina por não traduzir a melhor técnica legislativa (cf. ADALBERTO SIMÃo FILHO. "O espírito da Lei de Recuperação de Empresas e de Falência”, p. 2202. Disponível em http://www.conpedi.org.br/manaus/ arquivos/anais/brasilia/01_195.pdf. Acesso em: 16.12.2012.

${ }^{171} \mathrm{O}$ quadro-geral de credores constitui documento assinado pelo juiz e pelo administrador judicial que menciona a importância e classificação de cada crédito na data do requerimento da recuperação judicial, que será juntado aos autos e publicado no órgão oficial, no prazo de 5 dias, contado da data da sentença que houver julgado as impugnações (LRF, art. 18, par. único).
} 
judiciais proferidas nas impugnações e habilitações de crédito apresentadas pelos interessados $^{172}$ (LRF, art. 18).

Porém, se por conta da fase do processo ainda não tiver sido elaborado e homologado o quadro-geral, poderão participar da Assembleia os credores referidos no edital publicado pelo administrador judicial (LRF, art. $7^{\circ}, \S 2^{\circ}$ ), isto é, aqueles que tenham tido a sua condição reconhecida a partir da verificação conduzida pelo administrador judicial, com base nos livros contábeis, documentos comerciais e fiscais do devedor e demais documentos apresentados pelos próprios credores.

Finalmente, na hipótese de ainda não ter sido publicado esse edital, participarão da AGC os credores que constarem da relação apresentada pelo próprio devedor com a petição inicial do pedido de recuperação (LRF, art. 51, III e IV), admitindose, em qualquer caso, a participação dos credores que estejam habilitados na data da realização da assembleia ou que tenham créditos admitidos ou alterados por decisão judicial, inclusive os que tenham obtido reserva de importâncias.

\subsection{Na falência}

Na falência, a AGC é composta pelos credores do devedor que formam a chamada massa falida subjetiva ${ }^{173}$, excluindo-se apenas os credores de obrigações contraídas a título gratuito e das despesas feitas para tomar parte do processo concursal, inexigíveis nos termos do art. $5^{\circ}$, I, da LRF, e as obrigações assumidas no âmbito das câmaras ou prestadoras de serviços de compensação e de liquidação financeira, que serão

\footnotetext{
172 "Ao utilizar a expressão 'das que tenham sido habilitadas na data da assembléia-geral', o legislador não se referiu às habilitações apresentadas no prazo e ainda não decididas, mas àquelas já admitidas, ou seja, já decididas favoravelmente aos habilitantes" (TJSP, Câm. Fal. e Recup., AI no 0328576-81.2010.8.26.0000, rel. Des. Boris Kauffmann, j. 29.3.2011); citado por CRISTIANO IMHOF (Lei de recuperação de empresas... Op. cit., p. 187-188).

173 “Tendo em vista o processo de falência ser uma execução coletiva, sujeito ao princípio da par condicio creditorum, que proporciona tratamento igualitário a todos os credores da mesma categoria, devem todos eles concorrer ao juízo indivisível da falência, sejam comerciantes ou civis. São reunidos, em consequência, numa coletividade, conhecida por massa falida subjetiva. Como expõe o Prof. Otávio Mendes, é integrada pelos sujeitos dos direitos que compõem a comunhão dos credores, formada paralelamente à massa falida objetiva, que constitui o patrimônio do falido". (RUBENS REQUIÃo. Curso de direito falimentar. 4 ed. São Paulo: Saraiva, 1980. v. 1, p. 135).
} 
ultimadas e liquidadas pela câmara ou prestador de serviços, na forma de seus regulamentos (LRF, arts. 193 e 194) ${ }^{174}$.

Não parece possível excluir da AGC nem mesmo os credores que fazem jus à restituição (LRF, art. 86), pelo menos até que esta tenha sido realizada, na medida em que as deliberações tomadas pelos demais credores poderão influenciar na restituição daquilo que lhes é devido, notadamente nas hipóteses em que o pagamento desses credores depender da venda dos ativos do devedor ${ }^{175}$.

Assim como ocorre na recuperação judicial, só poderão participar da AGC os credores arrolados no quadro-geral de credores, ou, na sua falta, na relação publicada pelo administrador judicial na forma do art. $7^{\circ}, \S 2^{\circ}$, da LRF, ou, ainda, na falta desta, na relação apresentada pelo próprio falido em cumprimento da sentença que decretar a quebra ${ }^{176}$ ou

174 “A nova Lei de Falências, em seus arts. 193 e 194, vem ratificar o que já determinava a Lei n” 10.214/01. Trata-se da não sujeição das obrigações assumidas no âmbito das Câmara de Compensação e Liquidação Financeira às regras da execução concursal de falência por certas razões muito justificadas, alinhavadas adiante. Sendo assim, a despeito da decretação da falência da empresa participante dessa natureza de relação, as compensações e liquidações continuarão a ser efetuadas de acordo com o regulamento daquele que está prestando esse serviço. Portanto, percebe-se que os bens reservados ao patrimônio especial somente poderão ser utilizados no adimplemento das obrigações assumidas pela própria Câmara enquanto parte da relação, com o fim de garantir a liquidez do sistema financeiro. As obrigações originárias do emissor não poderão alcançar o patrimônio especial. Por isso, caso sobrevenha a falência do emissor, os bens reservados não poderão ser utilizados para o pagamento da massa falida." (JAIRO SADDI. In: CORRÊA-LIMA, Osmar Brina; e LIMA, Sérgio Mourão Correa (coord.). Comentários à nova Lei de Falência e Recuperação de Empresa. Rio de Janeiro: Forense, 2009, p. 1282-1283).

${ }^{175}$ Em sentido contrário, porém, assim se manifesta SÉRGIO CAMPINHO ao tratar do art. $39, \S 1^{\circ}$, da LRF, que exclui o direito de voto dos titulares de crédito decorrente de ACC, sujeito à restituição em caso de falência: "A presença do preceito indicado, ao revés, poderia gerar dúvida quanto ao direito de voto, no âmbito do processo de falência, por fazerem referência os $\S \S 3^{\circ}$ e $4^{\circ}$, do art. 49 (sic.), àqueles que sejam titulares de valores objeto de restituição (artigo 86). Mas de logo deve essa eventual dúvida surgida ser espancada. Os mencionados valores não são propriamente créditos, não participando o respectivo titular do concurso falimentar, não vindo a integrar, assim, o quadro-geral de credores" (Falência e recuperação de empresa. Rio de Janeiro: Renovar, 2006, p. 86). Discorda-se dessa opinião pois os valores recebidos a título de ACC não são outra coisa senão um crédito de quem fez o adiantamento, decorrente da obrigação do devedor de restituí-los. Por outro lado, conquanto essas importâncias não se sujeitem ao concurso sobre os bens do falido (o que é feito, não sem críticas, em razão de opção legislativa), ainda assim será com esses bens que se fará a restituição. Portanto, especialmente no caso de não haver dinheiro em caixa, a alienação dos demais ativos do devedor (bens que serão empregados inclusive para as restituições) é tema de potencial interesse dos credores de ACC.

176 Art. 99. A sentença que decretar a falência do devedor, dentre outras determinações (...) III - ordenará ao falido que apresente, no prazo máximo de 5 (cinco) dias, relação nominal dos credores, indicando endereço, importância, natureza e classificação dos respectivos créditos, se esta já não se encontrar nos autos, sob pena de desobediência”. 
instruindo o pedido de autofalência ${ }^{177}$. Em qualquer caso, também poderão participar os credores que estejam habilitados na data da realização da assembleia ou que tenham créditos admitidos ou alterados por decisão judicial.

\subsection{Comentário ao art. 40 da LRF}

Dispõe o art. 40 da LRF que não será deferido provimento liminar, de caráter cautelar ou antecipatório dos efeitos da tutela, para a suspensão ou adiamento da Assembleia-Geral de Credores em razão de pendência de discussão acerca da existência, da quantificação ou da classificação de créditos.

Vários autores sustentam a inconstitucionalidade desse artigo, por entenderem que ele exclui do Judiciário lesão ou ameaça a direito, em afronta ao art. $5^{\circ}, \mathrm{XXXV}$, da Constituição Federal. Nesse sentido se posicionam MANOEL Justino BEZERRA FILHO ${ }^{178}$, Julio Kahan MAdeL ${ }^{179}$, Frederico A. Monte Simionato ${ }^{180}$, entre outros.

Não se verifica, porém, a alegada inconstitucionalidade, pois não há direito subjetivo à suspensão ou adiamento da assembleia. $\mathrm{O}$ credor tem, sim, o direito de participar da assembleia, com todas as prerrogativas que a natureza e a extensão do seu crédito lhe deferem, bem como de impedir a participação de terceiros em desacordo com os limites do seu crédito. E para isso não há vedação alguma à concessão de provimento judicial liminar, como bem observa ERASMO VALADÃo A. E N. FrANÇA ${ }^{181}$. Ao contrário, a

\footnotetext{
${ }^{177}$ Art. 105. O devedor em crise econômico-financeira que julgue não atender aos requisitos para pleitear sua recuperação judicial deverá requerer ao juízo sua falência, expondo as razões da impossibilidade de prosseguimento da atividade empresarial, acompanhadas dos seguintes documentos: (...) II - relação nominal dos credores, indicando endereço, importância, natureza e classificação dos respectivos créditos”.

178 “O inciso XXXV do art. $5^{\circ}$ da Constituição Federal, consagrando o princípio da indeclinabilidade da jurisdição, estabelece que "a lei não excluirá da apreciação do Poder Judiciário lesão ou ameaça a direito", de tal forma que este art. 40 padece de inconstitucionalidade, devendo ser objeto de trato jurisprudencial" (No lei de recuperação e falências...Op. cit., p. 121).

179 “A situação é injusta ao credor e não pode, em tese, ficar sem proteção legal”. (Nova lei de falências $e$ recuperação de empresas anotada. São Paulo: Saraiva, 2005, p. 89).

180 "No meu entender o art. 40 da lei é manifestamente inconstitucional, impedindo o acesso à Justiça, cerceando o direito de defesa e petição, impondo tratamento desigual entre as partes" (Tratado de direito falimentar. Rio de Janeiro: Forense, 2008, p. 113

181 "Esse artigo [40] tem sido injustamente apodado de inconstitucional, em razão de suposta violação ao art. $5^{\circ}$, inciso XXXV, da Carta Magna(...). Injustamente porque a Lei $\mathrm{n}^{\circ} 11.101$ assegura aos credores - na hipótese de discussão acerca da existência, da quantificação ou da classificação de créditos - a participação
} 
lei contempla expressamente essa possibilidade no parágrafo único do art. 17, que prevê a atribuição liminar de efeito suspensivo ao agravo interposto contra a decisão do juiz que "reconhece o crédito ou determinar a inscrição ou modificação do seu valor ou classificação no quadro-geral de credores, para fins de exercício de direito de voto em assembléia-geral”.

Além disso, o art. 40 da LRF, a par de imprimir celeridade ao processo, prevenindo a indefinição ${ }^{182}$ sobre a crise do devedor, acha-se de acordo com a sistemática processual que envolve a concessão das tutelas de urgência e com a própria teoria das nulidades.

Em matéria societária, há muito se vem decidindo que não cabe medida cautelar ou tutela antecipada para impedir a própria realização da assembleia ${ }^{183}$ (salvo hipótese de determinados vícios de convocação), deferindo-se, tão somente, quando for caso, a suspensão dos efeitos das deliberações tomadas ${ }^{184}$.

É que, antes de se conhecer o resultado da assembleia e o teor dos votos proferidos, não é possível saber se existirá interesse de agir por parte daquele que teve a participação preterida ou diminuída pela participação de terceiros em desconformidade com o valor ou natureza do seu crédito. Assim como não é possível aferir, antes de tomada a deliberação, se ela estará viciada por alguma nulidade:

na Assembléia. Com efeito, se o juiz deixa de reconhecer um crédito, ou quantifica-o abaixo do valor pretendido pelo credor, ou ordena a sua classificação em outra classe, o credor poderá agravar, prevendo o parágrafo único do art. 17, que "recebido o agravo, o relator poderá conceder efeito suspensivo à decisão que reconhece o crédito ou determinar a inscrição ou modificação do seu valor ou classificação no quadro-geral de credores, para fins de exercício de direito de voto em assembléia-geral". (In: Comentários...Op. cit., p. 211).

${ }^{182}$ A indefinição é das coisas mais perniciosas ao processo concursal, pois implica, em regra, o perecimento dos ativos e da capacidade produtiva, o rompimento de relações comerciais e ainda por cima impede os credores do devedor de definir a estratégia a adotar, ou de agirem conforme esse entendimento.

183 Cf. Alfredo SÉRgIO LAZZARESCHI NETO, “em regra, não cabe cautelar para impedir a própria realização da assembleia: 'Medida cautelar inominada. Liminar impedindo o diretor de sociedade anônima de praticar atos referentes à incorporação da empresa. Ausência de fumus boni iuris e periculum in mora. Agravo provido. Não se pode a priori impedir até mesmo a realização de um futuro ato societário, de incerta realização, pois ainda desconhecida a relevância jurídica e ausente o periculum in mora" (Lei das Sociedades por Ações anotada. 4 ed. São Paulo: Saraiva, 2012, p. 820).

${ }^{184}$ A respeito do tema, confira-se PRISCILA M.P. CORRÊA DA FONSECA (Suspensão das deliberações sociais. São Paulo: Saraiva, 1986, p. 77-80 e LuZ FERNANDO C. PEREIRA (Medidas urgentes no direito societário. São Paulo Revista dos Tribunais, 2002, p. 130-139). 
"A distorção parece enorme, pois, se a assembléia não se realiza, não se pode definir ao certo o teor da deliberação que iria ser tomada, nem os seus fundamentos, pelo que o próprio juiz acaba privando-se da possibilidade de examinar, no âmbito do processo principal, os motivos pelos quais a deliberação contestada deve ser ou não mantida, de acordo com o interesse da comunidade de acionistas (...). Tudo isto deve levar a que não se suspenda a priori, a não ser em casos excepcionalíssimos, a própria assembléia geral e/ou a discussão de uma certa matéria no âmbito da assembléia, restringindo-se o Poder do Judiciário a diferir no tempo a eficácia da deliberação" (PAULO CÉSAR ARAGÃO ${ }^{185}$ ).

As mesmas razões podem ser aplicadas à Assembleia-Geral de Credores, permitindo concluir que a vedação às tutelas de urgência destinadas a suspender ou adiar a reunião não é inconstitucional, ressalvando-se a possibilidade de o juiz, depois de realizada a assembleia, suspender os efeitos das deliberações tomadas ${ }^{186}$.

\section{Instâncias deliberativas}

Como visto acima, a Assembleia-Geral de Credores, salvo algumas exceções, é composta por todos os credores do devedor.

Conforme a matéria objeto de deliberação, os credores que compõem a AGC permanecerão reunidos (num único grupo) ou serão divididos em classes. Por isso, afirmase que a AGC contempla duas instâncias deliberativas ${ }^{187}$ : (i) o plenário, composto

\footnotetext{
185 “Aspectos processuais da legislação societária”. Revista dos Tribunais, São Paulo, n. 641, p. 61.

${ }^{186}$ Para JAIRO SADDI, embora o art. 40 da LRF se limite a vedar as tutelas de urgência destinadas a suspender ou a adiar a própria assembleia, da interpretação sistemática desse dispositivo decorria também a vedação à suspensão liminar das deliberações assembleares: "De acordo com a lei, não se pode adiar a Assembléia Geral de Credores; porém, ela não contempla a suspensão de seus efeitos. Isso significa que, realizada a assembléia, aqueles que se sentirem prejudicados pelas deliberações poderiam defender seus direitos suspendendo seus efeitos, não a reunião em si. Apesar de aceitável, tal possibilidade acarretaria aos processos de falência e recuperação morosidade e agressão ao princípio da celeridade. (...) Por isso, a correta interpretação do dispositivo mostra a impossibilidade tanto de adiar a Assembléia de Credores como de suspender os efeitos das deliberações porventura efetuadas" ("Suspensão e invalidação da assembléia geral de credores. In: CASTRO, Rodrigo R. Monteiro de; e ARAGÃO, Leandro Santos de (coords.). Direito societário e a nova lei de falências e recuperação de empresas. São Paulo: Quartier Latin, 2006, p. 47).

${ }^{187}$ Segundo JAIRO SADDI: "Na Assembleia de Credores, existem duas instâncias deliberativas que variam de acordo com a matéria em discussão: a) plenário e b) classes de credores definidas em lei” (JAIRO SADDI. In: CORRÊA-LIMA, Osmar Brina; e LIMA, Sérgio Mourão Correa (coord.). Comentários à nova Lei de Falência e Recuperação de Empresa. Rio de Janeiro: Forense, 2009, p. 293). Já FÁBIO UlHOA COELHO afirma que seriam quatro as instâncias deliberativas: o plenário e cada uma das três classes de credores referidas no art. 41 da LRF (Comentários...Op. cit.,. p. 149). Parece mais acertada a posição defendida pelo primeiro autor, haja vista que a competência atribuída às classes de credores é a mesma.
} 
indistintamente por todos os credores, e (ii) as classes, nas quais o credores são divididos segundo a natureza ou prioridade do crédito.

Em regra, as principais deliberações da $\mathrm{AGC}$, quer na recuperação judicial, quer na falência, sujeitam-se à deliberação das classes de credores, enquanto que o plenário é dotado de competência residual ${ }^{188}$. Vale dizer, à exceção das matérias expressamente reservadas às classes de credores (quais sejam, a aprovação do plano de recuperação e a constituição do Comitê de Credores), todas as demais são deliberadas pelo plenário.

Além de possuírem competências diversas, a forma como se dá a deliberação no âmbito dessas duas instâncias também é distinta. O plenário delibera segundo a vontade manifestada pelos titulares representantes da maioria dos créditos, independentemente de sua natureza, enquanto que nas classes de credores a deliberação se dá não apenas em razão do valor do crédito, mas também por cabeça, ou somente por cabeça, como será explicado adiante ${ }^{189}$.

Além disso, a forma como a vontade da maioria se impõe sobre a minoria é diferente no plenário e nas classes, porque no âmbito interno destas os vencidos se sujeitam à deliberação da maioria, mas todos, inclusive aqueles que prevalecerem em suas respectivas classes, sujeitam-se à decisão combinada das três classes. De modo que o vencedor na própria classe poderá sair vencido da assembleia, diante das deliberações tomadas nas demais classes.

A composição das classes de credores é tratada em dois artigos da Lei $\mathrm{n}^{\circ}$ 11.101/2005: no art. 26, inserto na seção que trata do Comitê de Credores, e no art. 41, incluído na seção da lei que trata especificamente da Assembleia-Geral de Credores. Curiosamente, em razão de indisfarçável "cochilo"190 do legislador, a composição das classes para a eleição dos membros do Comitê de Credores é ligeiramente diversa da

\footnotetext{
${ }^{188}$ Cf. JAIRO SADDI. Comentários... Op.cit., p. 293.

${ }^{189}$ Vide item 9.

${ }^{190}$ FÁBIO ULHOA COELHO explica que "essa incongruência deveu-se à imprecisão da Emenda 57, apresentada em Plenário pela senadora Ideli Salvatti quando da votação do Projeto pelo Senado, em julho/2004. A emenda alterou a redação do art. 41, para isolar numa única classe de credores com garantia real, mas se esqueceu de fazer igual mudança no art. 26" (Comentários... Op. cit., p. 114).
} 
composição estabelecida para todas as demais deliberações de competência das classes de credores.

Enquanto o art. 26 inclui os credores com privilégios especiais na mesma classe dos credores com garantia real, o art. 41 deixa os credores dotados de garantia real sozinhos numa única classe, reunindo os credores com privilégios especiais na mesma classe dos credores quirografários, com privilégio geral e subordinados.

Daí que, por conta do critério da especialidade, prevalecerá a divisão prevista no art. 26 quando da eleição dos representantes do Comitê de Credores ${ }^{191}$.

\subsection{As classes de credores}

As principais matérias de competência da AGC são decididas pelas classes de credores. Na recuperação judicial, a aprovação do plano depende da deliberação das classes (arts. 26 e 45), enquanto que, na falência, compete a elas a aprovação de forma alternativa de liquidação dos ativos do devedor (art. 145).

Nos termos do art. 41 da LRF, a AGC será composta pelas seguintes classes de credores: Classe I, formada pelos titulares de créditos derivados da legislação do trabalho ou decorrentes de acidentes de trabalho; Classe II, formada pelos titulares de créditos com garantia real; e Classe III, formada pelos titulares de créditos quirografários, com privilégio especial, com privilégio geral ou subordinados.

Como se vê, o critério de divisão das classes respeita a ordem de preferência dos créditos na falência, conforme estabelecido pelo art. 83 da $\operatorname{LRF}^{192}$.

191 "Sublinhe-se, uma vez mais, que as classes de credores previstas no art. 26, I II e III - para eleição do Comitê de Credores - são diversas das classes previstas no art. 41. Para aquela eleição, portanto, prevalece a disposição especial do art. 26.” (ERASMO VALADÃO A. E N. FRANÇA. In: Comentários... Op. cit., p. 212). 


\subsubsection{Classe I}

A Classe I é composta pelos titulares de créditos derivados da legislação do trabalho ou decorrentes de acidentes de trabalho, que votam nessa classe com a integralidade do seu crédito ${ }^{193}$, independentemente do valor. Ao prever que os credores trabalhistas votam com a integralidade do seu crédito, o $\S 1^{\circ}$ do art. 41 da LRF tem o intuito de evitar a interpretação de que esses credores só votariam na classe I até 150 salários mínimos, limite da prioridade a eles conferida no recebimento dos créditos na falência (LRF, art. 83, I).

Ela compreende, assim, não apenas as relações de emprego ${ }^{194}$, mas todas as relações de trabalho ${ }^{195}$ (autônomos, trabalhadores eventuais, avulsos ou temporários) ${ }^{196}$.

${ }^{192}$ Art. 83. A classificação dos créditos na falência obedece à seguinte ordem: I - os créditos derivados da legislação do trabalho, limitados a 150 (cento e cinqüenta) salários-mínimos por credor, e os decorrentes de acidentes de trabalho; II - créditos com garantia real até o limite do valor do bem gravado; III - créditos tributários, independentemente da sua natureza e tempo de constituição, excetuadas as multas tributárias; IV créditos com privilégio especial, a saber: a) os previstos no art. 964 da Lei $\mathrm{n}^{\circ} 10.406$, de 10 de janeiro de 2002; b) os assim definidos em outras leis civis e comerciais, salvo disposição contrária desta Lei; c) aqueles a cujos titulares a lei confira o direito de retenção sobre a coisa dada em garantia; $\mathrm{V}$ - créditos com privilégio geral, a saber: a) os previstos no art. 965 da Lei $n^{\circ}$ 10.406, de 10 de janeiro de 2002; b) os previstos no parágrafo único do art. 67 desta Lei; c) os assim definidos em outras leis civis e comerciais, salvo disposição contrária desta Lei; VI - créditos quirografários, a saber: a) aqueles não previstos nos demais incisos deste artigo; b) os saldos dos créditos não cobertos pelo produto da alienação dos bens vinculados ao seu pagamento; c) os saldos dos créditos derivados da legislação do trabalho que excederem o limite estabelecido no inciso I do caput deste artigo; VII - as multas contratuais e as penas pecuniárias por infração das leis penais ou administrativas, inclusive as multas tributárias; VIII - créditos subordinados, a saber: a) os assim previstos em lei ou em contrato; b) os créditos dos sócios e dos administradores sem vínculo empregatício.

${ }^{193}$ Note-se, na aprovação do plano de recuperação segundo a regra do art. 45, os votos dos credores da Classe I são computados exclusivamente por cabeça, e não por valor.

194 "Quando a lei dispõe sobre relação de trabalho, quer se referir a contrato de trabalho. (...) Mas não se controverte que relação de trabalho é um gênero, ou, em outras palavras, contrato de trabalho é um gênero, e não se confunde com relação de emprego ou contrato de emprego, que é uma modalidade - a mais importante - de contrato de trabalho." (AMAURi MASCARO NASCIMENTO. Curso de Direito do Trabalho. 26 ed. São Paulo: Saraiva, 2011, p. 546). O conceito da relação de emprego é extraído do art. $3^{\circ}$ da Consolidação das Leis do Trabalho, que considera empregado "toda pessoa física que prestar serviços de natureza não eventual a empregador, sob a dependência deste e mediante salário”. Assim, relação de emprego é aquela que reúne os seguintes elementos: (i) prestação de serviços por pessoa física; (ii) em caráter não eventual; (iii) mediante o pagamento de salário; e (iv) com subordinação ao empregador.

${ }^{195}$ Cf. Marlon TOMazette. Curso de Direito Empresarial ...Op. cit., p. 137. 
JAIRO SADDI ${ }^{197}$ adverte que "ao se utilizar da expressão 'créditos derivados da legislação do trabalho, o legislador abre espaço para que um sem-número de credores sejam aí qualificados", abrangendo inclusive "os trabalhadores que não estão mais empregados na empresa, ou mesmo aqueles que ajuizaram ação trabalhista e tiveram sentença transitada em julgado". Daí conclui o autor que:

"Desse modo, partindo-se do pressuposto de que pessoas que não mais trabalham ou mesmo que nunca tiveram vínculo empregatício com a empresa devedora não tenham interesse em sua recuperação, podemos concluir que a tomada de decisões dentro dessa classe de credores pode apresentar alguns obstáculos, principalmente no tocante ao eventual conflito de interesses entre aqueles que visam somente liquidar os ativos e os que objetivam a reestruturação da empresa em dificuldades."

Note-se, porém, que os créditos trabalhistas cedidos a terceiros, gratuita ou onerosamente, serão considerados quirografários (LRF, art. $83^{\circ}, \S 4^{\circ}$ ), o que é feito como forma de se evitar que terceiro se aproveite da situação de penúria dos empregados para comprar esses créditos com deságio ${ }^{198}$.

\subsubsection{Classe II}

A Classe II é composta pelos titulares de créditos com garantia real, ou seja, dos credores que gozam de direito real de garantia, que, por definição, confere ao credor a pretensão de obter o pagamento da dívida com o valor do bem aplicado exclusivamente à

\footnotetext{
${ }^{196}$ O Tribunal de Justiça de São Paulo já decidiu que a classe I, em certos casos, abrange até o representante comercial autônomo: “Agravo de Instrumento. Impugnação à relação de credores. Crédito decorrente de representação comercial titularizado por representante comercial autônomo, pessoa natural, que exerce sua atividade em nome próprio, equipara-se aos créditos derivados da legislação do trabalho. (...). A equiparação do crédito derivado de representação comercial aos créditos decorrentes da legislação de trabalho, na falência e na recuperação judicial (art. 83, I, LRF), só pode ser reconhecida, como na hipótese em exame, em que o representante comercial é pessoa física ou "firma individual" inscrito como empresário individual no Registro de Empresas. Agravo desprovido, mantida a equiparação do crédito do representante comercial autônomo aos créditos derivados da legislação do trabalho." (TJSP, Câm. Fal. e Recup., AI no 526.878.4/600, Rel. Des. Pereira Calças, j. 27.2.2008).

${ }^{197}$ In: CORRÊA-LIMA, Osmar Brina [et. al.] (coord.). Comentários... Op. cit., p. 287.

198 "Na sua essência, a regra visa evitar a compra ou cessão de créditos em mãos de terceiros que contariam com as mesmas regalias do credor originário" (CARLOS HENRIQUE ABRÃO. Comentários à Lei de Recuperação de Empresas e Falência. 4 ed. Obra coletiva coordenada por ele e Paulo F. C. Salles de Toledo. São Paulo: Saraiva, 2012, p. 309).
} 
sua satisfação. É o caso da hipoteca, do penhor, da anticrese e de outras garantias reais previstas em leis especiais $^{199}$.

Conforme ORLANDO GOMES ${ }^{200}$, “sua função é garantir ao credor o recebimento da dívida, por estar vinculado determinado bem ao seu pagamento, O direito do credor 'concentra-se sobre determinado elemento patrimonial do devedor'”. Além disso, a garantia real dá ao credor "direito a pagamento preferencial, obtendo a satisfação do seu crédito antes de outros credores. O bem gravado é aplicado à satisfação exclusiva da dívida, sendo subtraído, no limite do seu valor, à execução coletiva. O credor tem, desse modo, direito de preferência ${ }^{201}$,.

Os credores com garantia real votam na classe II até o limite do valor do bem gravado e com a classe III (dos credores quirografários, privilegiados ou subordinados) pelo restante do valor do seu crédito (LRF, art. $41, \S 2^{\circ}$ ).

Uma enorme dificuldade para o cômputo dos votos na classe dos credores com garantia real consiste justamente em definir o valor do bem dado em garantia, máxime se ainda não houve nenhuma avaliação e se o bem não foi alienado.

Na recuperação judicial, a praxe tem sido a seguinte: os credores com garantia real votam na Classe II de acordo com o valor do bem declarado pelo próprio devedor (LRF, art. 51, III), ou daquele eventualmente constante do título de garantia. No mais das vezes, à falta de avaliação do bem, acabam votando na Classe II com a integralidade do seu crédito, seja porque as garantias exigidas pelos bancos costumam superar o valor do crédito, seja porque não há impugnação por parte dos credores quanto ao valor atribuído ao bem para efeito de votação.

\footnotetext{
199 Ressalva-se, porém, que o titular da posição de proprietário fiduciário de bens móveis ou imóveis, conquanto goze de direito real de garantia, não tem direito de voto na AGC realizada durante a recuperação judicial (LRF, art. $39, \S 1^{\circ}$ c.c. art. $49, \S 3^{\circ}$ ).

${ }^{200}$ Direito das Coisas. 13 ed. Rio de Janeiro: Forense, 1998, p. 344.

${ }^{201}$ Exceto, na falência, em relação aos credores trabalhistas, até 150 salários mínimos por trabalhador, aos créditos extraconcursais e aos pedidos de restituição, que também gozam de prioridade em relação aos credores com garantia real.
} 
Somente isso explica a inexistência - até um pouco surpreendente - de decisões judiciais acerca do tema, que não é nada desimportante, na medida em que o valor atribuído ao bem poderá, em certos casos, definir o sentido da deliberação de toda classe e o resultado da própria assembleia.

\subsubsection{Classe III}

A Classe III formada pelos titulares dos créditos com privilégio especial ou geral, quirografários e subordinados, que votam segundo o valor total do seu crédito.

Créditos com privilégio especial ou geral são pagos antes dos créditos quirografários ou sub-quirografários, embora sejam preteridos em relação aos créditos com garantia real, segundo a regra de que "o crédito real prefere ao pessoal de qualquer espécie; o crédito pessoal privilegiado, ao simples; e o privilégio especial, ao geral" (Código Civil, art. 961).

O privilégio especial prefere ao geral, vinculando-se a determinado bem do patrimônio do devedor que deu origem ao crédito $^{202}$, mas sem conferir ao titular o direito de sequela, diferentemente do que ocorre com a garantia real; já o privilégio geral incide sobre a totalidade dos bens do devedor, indistintamente:

"O privilégio especial incide tão-somente sobre o bem que lhe deu origem, sendo certo que na eventualidade do seu desaparecimento, o crédito passará à categoria de quirografário, assim concorrendo com os outros credores. Como afirma Pontes de Miranda: 'Em vez de ser prelação em todo o ativo, o privilégio especial cai em bem, ou parte do patrimônio, que a lei especialmente indica para em seu valor se satisfazer o credor'. Em suma, o privilégio especial não se transfere para o patrimônio do devedor, incidindo, apenas sobre o bem que gerou o privilégio, inexistindo direito de sequela. $\mathrm{O}$ privilégio geral, por seu turno, incide sobre a totalidade indeterminada do patrimônio do devedor." (CARLOS AlberTo MENEZES DiREITO ${ }^{203}$ ).

\footnotetext{
${ }^{202}$ Cf. Nelson ABRÃo. Os credores na falência. 2 ed. Leud: São Paulo, 1998, p. 75.

${ }^{203}$ Comentários ao Novo Código Civil: Da responsabilidade civil. Das preferências e privilégios creditórios. Coord. de Sálvio Figueiredo Teixeira. Rio de Janeiro: Forense, 2004. v. 13, p. 496.
} 
Assim é que, nos termos do art. 963 do Código Civil, o privilégio especial compreende apenas os bens sujeitos, por expressa disposição legal, ao pagamento do crédito que ele favorece. Conclui-se, por isso, a partir da interpretação sistemática da legislação, que a extensão do privilégio se limita ao valor apurado com a venda do bem a que ele se vincula ${ }^{204}$, ainda que a LRF não disponha isso expressamente ${ }^{205}$.

Segundo o art. 83, IV, da LRF, são créditos com privilégio especial: (i) os previstos no art. 964 do Código Civil ${ }^{206}$ (que estabelece, p. ex., que o credor por benfeitorias necessárias ou úteis tem preferência em relação ao produto da alienação da coisa beneficiada) ${ }^{207}$; (ii) os assim definidos em outras leis civis e comerciais, como, p. ex., os créditos a cargo da embarcação sobre o preço do navio (Código Comercial ${ }^{208}$, art. 475); e (iii) aqueles a cujos titulares a lei confira o direito de retenção sobre a coisa dada em garantia, como se dá com o depositário sobre a coisa dada em depósito ou com o mandatário sobre a coisa possuída em razão do mandato (Código Civil, arts. 644 e 681, respectivamente).

\footnotetext{
204 "Permitir que o privilégio especial fosse além do valor do bem vinculado ao crédito seria propiciar o enriquecimento imotivado dos credores com privilégio especial, em detrimento do concurso com os credores menos favorecidos" (SÉRGIO MOURÃo CORRÊA LIMA. In: CORRÊA-LIMA, Osmar Brina [et. al.] (coord.). Comentários... Op. cit., p. 547).

205 Diferentemente do que faz em relação aos créditos reais, cuja preferência foi expressamente limitada ao valor do bem gravado (LRF, art. 83, II), inclusive para efeito do exercício do voto na classe II da AGC (LRF, art. $\left.41, \S 2^{\circ}\right)$.

${ }^{206}$ Art. 964. Têm privilégio especial: I - sobre a coisa arrecadada e liquidada, o credor de custas e despesas judiciais feitas com a arrecadação e liquidação; II - sobre a coisa salvada, o credor por despesas de salvamento; III - sobre a coisa beneficiada, o credor por benfeitorias necessárias ou úteis; IV - sobre os prédios rústicos ou urbanos, fábricas, oficinas, ou quaisquer outras construções, o credor de materiais, dinheiro, ou serviços para a sua edificação, reconstrução, ou melhoramento; V - sobre os frutos agrícolas, o credor por sementes, instrumentos e serviços à cultura, ou à colheita; VI - sobre as alfaias e utensílios de uso doméstico, nos prédios rústicos ou urbanos, o credor de aluguéis, quanto às prestações do ano corrente e do anterior; VII - sobre os exemplares da obra existente na massa do editor, o autor dela, ou seus legítimos representantes, pelo crédito fundado contra aquele no contrato da edição; VIII - sobre o produto da colheita, para a qual houver concorrido com o seu trabalho, e precipuamente a quaisquer outros créditos, ainda que reais, o trabalhador agrícola, quanto à dívida dos seus salários.

207 "Nos diversos incisos [do art. 964 do Código Civil], foram arrolados créditos com privilégio especial sobre a coisa que lhes deu origem. Têm basicamente duas origens: $1^{a}$ ) o ressarcimento de despesas incorridas com a manutenção, em termos genéricos, de bens sujeitos ao concurso de credores (incisos I, II, III, IV, V); $2^{\mathrm{a}}$ ) o pagamento pelo serviço realizado por terceiro (incisos VII e VIII). O inciso IV, ao tratar do privilégio do credor de aluguéis sobre as alfaias de bens de uso doméstico, é exceção à regra." (CARLOS ALBERTO Menezes DiReito. Comentários ao Novo Código Civil...Op. cit., v. 13, p. 498).
}

${ }^{208}$ Recorde-se que, mesmo com a edição do Código Civil de 2002, manteve-se vigente a parte segunda do Código Comercial (Lei n ${ }^{\circ}$ 556/1850), relativa ao comércio marítimo. 
Note-se que, embora o art. 83, IV, da LRF trate como créditos privilegiados aqueles referidos no art. 964 do Código Civil, sem fazer qualquer exceção, nem todos ali elencados gozam dessa natureza no regime da lei falimentar. É o caso do inciso I do art. 964, que confere privilégio sobre a coisa arrecadada e liquidada a créditos que são inexigíveis na recuperação judicial e na falência, quais sejam, as custas e despesas judiciais feitas com a arrecadação e liquidação (LRF, art. 5º II) ${ }^{209}$. Além disso, também não se aplica o inciso VIII do art. 964, que confere privilégio ao trabalhador agrícola sobre o produto da colheita.

O privilégio geral, por sua vez, incide sobre a totalidade dos bens do devedor. Conforme o art. 83, V, da LRF, consideram-se créditos com privilégio geral: (i) os previstos no art. 965 do Código Civil $^{210}$; (ii) aqueles arrolados no parágrafo único do art. 67 da própria lei concursal; e (iii) os assim definidos em outras leis civis ou comerciais.

Quanto aos créditos previstos no art. 965 do Código Civil, aqueles arrolados nos incisos II e VI não têm aplicação no regime da LRF: despesas com a arrecadação e liquidação da massa e custas judiciais do processo de falência (prevista no inciso II) são consideradas créditos extraconcursais e pagas com prioridade sobre os débitos do falido ${ }^{211}$; os créditos tributários (referidos no inciso VI) ocupam o terceiro lugar na ordem de pagamento na falência, antes dos créditos privilegiados. Já os privilégios indicados nos incisos I, III, IV, V e VII dizem respeito apenas aos gastos decorrentes do falecimento do empresário individual ou do sócio de responsabilidade ilimitada.

\footnotetext{
209 Art. $5^{\circ}$. Não são exigíveis do devedor, na recuperação judicial ou na falência: (...) II - as despesas que os credores fizerem para tomar parte na recuperação judicial ou na falência, salvo as custas judiciais decorrentes de litígio com o devedor.

${ }^{210}$ Art. 965. Goza de privilégio geral, na ordem seguinte, sobre os bens do devedor: I - o crédito por despesa de seu funeral, feito segundo a condição do morto e o costume do lugar; II - o crédito por custas judiciais, ou por despesas com a arrecadação e liquidação da massa; III - o crédito por despesas com o luto do cônjuge sobrevivo e dos filhos do devedor falecido, se foram moderadas; IV - o crédito por despesas com a doença de que faleceu o devedor, no semestre anterior à sua morte; $\mathrm{V}$ - o crédito pelos gastos necessários à mantença do devedor falecido e sua família, no trimestre anterior ao falecimento; VI - o crédito pelos impostos devidos à Fazenda Pública, no ano corrente e no anterior; VII - o crédito pelos salários dos empregados do serviço doméstico do devedor, nos seus derradeiros seis meses de vida; VIII - os demais créditos de privilégio geral.

${ }^{211}$ Art. 84 da LRF. Serão considerados créditos extraconcursais e serão pagos com precedência sobre os mencionados no art. 83 desta Lei, na ordem a seguir, os relativos a: III - despesas com arrecadação, administração, realização do ativo e distribuição do seu produto, bem como custas do processo de falência;
} 
O parágrafo único do art. 67 da LRF, no intuito de estimular a preservação da empresa, confere privilégio geral, em caso de falência, aos créditos quirografários pertencentes a fornecedores de bens ou serviços que continuarem a prover normalmente o devedor mesmo depois de protocolado o pedido de recuperação judicial, no limite do valor dos bens ou serviços fornecidos durante o período da recuperação.

Existem ainda outras leis que conferem privilégio geral, como o Estatuto da $\mathrm{OAB}$, em relação ao crédito de honorários advocatícios, contratuais e de sucumbência (Lei $\mathrm{n}^{\mathrm{o}} 8.906 / 94$, art. 24) $)^{212}$, e a Lei das S/A, no tocante às debêntures dotadas de garantia flutuante (Lei $n^{\circ} 6.404 / 76$, art. 58, $\left.\S 1^{\circ}\right)^{213}$.

Vale ainda mencionar que os créditos fiscais poderão, conforme o caso, gozar de privilégio especial ou geral (CTN, arts. 184 e 186) $)^{214}$. Assim, para aqueles que entendem que a Fazenda tem a prerrogativa de participar das deliberações da AGC (o que só se admitiria na falência, vez que excluída ${ }^{215}$ dos efeitos da recuperação judicial), comporia ela a Classe III. Tal entendimento, contudo, não tem prevalecido, haja vista a inexistência de lei que permita à Fazenda transacionar no processo concursal ${ }^{216}$.

\footnotetext{
${ }^{212}$ Art. 24. A decisão judicial que fixar ou arbitrar honorários e o contrato escrito que os estipular são títulos executivos e constituem crédito privilegiado na falência, concordata, concurso de credores, insolvência civil e liquidação extrajudicial.

${ }^{213}$ Art. 58. A debênture poderá, conforme dispuser a escritura de emissão, ter garantia real ou garantia flutuante, não gozar de preferência ou ser subordinada aos demais credores da companhia. § $1^{\circ} \mathrm{A}$ garantia flutuante assegura à debênture privilégio geral sobre o ativo da companhia, mas não impede a negociação dos bens que compõem esse ativo.

${ }^{214}$ Art. 184. Sem prejuízo dos privilégios especiais sobre determinados bens, que sejam previstos em lei, responde pelo pagamento do crédito tributário a totalidade dos bens e das rendas, de qualquer origem ou natureza, do sujeito passivo, seu espólio ou sua massa falida, inclusive os gravados por ônus real ou cláusula de inalienabilidade ou impenhorabilidade, seja qual for a data da constituição do ônus ou da cláusula, excetuados unicamente os bens e rendas que a lei declare absolutamente impenhoráveis.
}

Art. 186. O crédito tributário prefere a qualquer outro, seja qual for sua natureza ou o tempo de sua constituição, ressalvados os créditos decorrentes da legislação do trabalho ou do acidente de trabalho.

${ }^{215}$ Cf. se depreende dos arts. $6^{\circ}, \S 7^{\circ}, 57$ e 68 da LRF e do art. 187 do CTN.

216 “(...) na assembleia de credores na falência surge uma questão nova, que diz respeito ao crédito tributário. Esse problema não ocorre na recuperação judicial, à qual o crédito tributário não está sujeito, nos termos do art. 187 do CTN, com a redação determinada pela Lei Complementar 118/2005. (...) não havendo lei expressa, não é possível o físco participar de assembleia-geral de credores na falência, para concordar com qualquer outra forma de liquidação do ativo além daquelas previstas nos arts. 140 e 142 da Lei 11.101/2005". (Luis Felipe Salomão e Paulo Penalva Santos. Recuperação judicial, extrajudicial e falência. Rio de Janeiro: Forense, 2012, p. 136 e 138). 
Ao lado dos créditos privilegiados, a Classe III é ocupada pelos créditos quirografários, também chamados créditos ordinários ou comuns, porque desprovidos de garantias ou privilégios.

No regime falimentar, os créditos quirografários são definidos por exclusão, sendo assim reputados (i) os créditos a que a LRF não atribui definição diversa, (ii) os saldos dos créditos não cobertos pelo produto da alienação dos bens vinculados ao seu pagamento $^{217}$, (iii) os saldos dos créditos derivados da legislação do trabalho que excederem o limite de 150 salários-mínimos por trabalhador (LRF, art. 83, VI) e ainda os créditos trabalhistas cedidos a terceiros (LRF, art. $83, \S 4^{\circ}$ ).

O parágrafo $2^{\circ}$ do art. 41 expressamente estabelece que os titulares de créditos com garantia real votam com a Classe II até o limite do valor do bem gravado e com a Classe III pelo restante do valor de seu crédito. Não houve necessidade de estabelecer regra idêntica em relação aos créditos com privilégio especial porque estes já votam na mesma classe dos quirografários.

Ressalte-se, porém, que, embora se considerem quirografários os créditos derivados da legislação do trabalho que excederem 150 salários-mínimos por trabalhador, para efeito de composição das classes da AGC os credores trabalhistas sempre ocuparão a Classe I, a despeito do valor do seu crédito.

É o que se depreende o parágrafo primeiro do art. 41 da LRF, conforme ensina JAIRO SADDI ${ }^{218}$ :

"Com o intuito de evitar incorretas interpretações da lei, o legislador determina que os credores trabalhistas votem na primeira classe com todo o valor de seu crédito. Isso porque, ao estabelecer a ordem de recebimento dos créditos na falência, a despeito de colocar os trabalhistas em primeiro lugar na lista, o legislador faz a seguinte ressalva: 'Os créditos derivados da legislação do trabalho, limitados a 150 (cento e cinquenta) salários mínimos por credor, e os decorrentes de acidente de trabalho (artigo 83, I).' Assim sendo, para que tal

\footnotetext{
${ }^{217}$ Isto é, créditos dos credores com garantia real ou privilégio especial na parte que superarem o valor do bem dado em garantia ou que deu causa ao privilégio especial.

${ }^{218}$ In: CORRÊA-LIMA, Osmar Brina [et. al.] (coord.). Comentários...Op. cit., p. 288.
} 
restrição não fosse transferida também às deliberações da Assembleia de Credores - na qual, nesse casos, os trabalhistas votariam na primeira classe no limite de 150 salários mínimos -, a Lei estabelece que titulares de créditos derivados da legislação do trabalho votam com a classe dos trabalhadores, independentemente do valor".

Por fim, a composição da Classe III completa-se com os créditos subordinados, que juntamente com multas contratuais e penas pecuniárias são chamados de créditos sub-quirografários, porque pagos depois dos créditos quirografários.

Os créditos subordinados compreendem (i) os previstos em lei, (ii) aqueles assim definidos em contrato e (iii) os créditos dos sócios ${ }^{219}$ e dos administradores sem vínculo empregatício (LRF, art. 83, VIII).

A par da lei falimentar, os créditos subordinados se acham previstos na Lei das S/A, cujo art. $58, \S 4^{\circ}$, dispõe que a debênture sem garantia poderá conter cláusula de subordinação aos credores quirografários, preferindo apenas aos acionistas no ativo remanescente, em caso de liquidação da companhia. Ignora-se, porém, a existência de outras leis que estabeleçam tal categoria de crédito.

A definição de créditos subordinados em contratos é coisa raríssima e, que, ademais, não suscita maiores dúvidas.

Os sócios do devedor e seus administradores, por outro lado, são privados do direito de voto na AGC, de modo que não compõem nenhuma das classes deliberativas, nem mesmo a classe de que participam os créditos subordinados (LRF, art. 43) 220.

\footnotetext{
${ }^{219}$ Questão interessante diz respeito ao significado da expressão "créditos dos sócios", que encerra certa ambiguidade. Num primeiro sentido, compreenderia todos os créditos titularizados pelo sócio, independentemente da sua causa (inclusive, p. ex., o decorrente de mútuo celebrado com a sociedade, ou de uma indenização). Numa segunda acepção, "créditos dos sócios” seriam apenas advindos do status de sócio. Para SÉRGIO MOURÃo CORRÊA LIMA, "os créditos dos sócios junto à sociedade podem consistir em: (a) dividendos (lucro) e (b) haveres, nas hipóteses de retirada ou de exclusão de sócio”. Mas como não são oponíveis à massa os valores decorrentes de direito de sócio ao recebimento da sua parcela do capital social na liquidação (haveres), conclui o citado autor que "os créditos dos sócios referidos na alínea b do art. 83, VIII, da Lei $n^{o}$ 11.101/2005 somente podem consistir em dividendos (lucros) dos exercícios anteriores, que não tenham sido distribuídos oportunamente" (In: Comentários...Op. cit., p. 557). Em sentido diverso, FRANCISCO SATIRO afirma que o crédito decorrente do mútuo celebrado entre o sócio e a sociedade também será considerado crédito subordinado, desde que não tenha outro privilégio. SATIRO admite, portanto, a inclusão de créditos de sócios ou administradores em outra classe, mas adverte que isso deverá ser analisado com especial atenção pelo administrador judicial e demais interessados, em face da possibilidade de fraude (Comentários....Op. cit., p. 365).
} 


\subsection{Justificativas para a divisão dos credores em classes}

A imposição pura e simples da vontade de quem tem o maior crédito, independentemente dos interesses dos demais e de quaisquer outras considerações, acaba por alijar grande parte dos credores do processo decisório, gerando o desinteresse destes e produzindo deliberações sem legitimidade. Tudo em prejuízo da eficiência do processo concursal, da circulação de crédito e dos demais princípios informadores do regime da insolvência, sobretudo da preservação da empresa.

Foi por conta disso que o legislador brasileiro resolveu romper com esse sistema ao editar o Decreto-Lei $\mathrm{n}^{\mathrm{o}} 7.661 / 45$, tirando dos credores o poder de decidir sobre a concessão da concordata.

Na exposição de motivos subscrita pelo Ministro Alexandre Marcondes, a carência de legitimidade da decisão da maioria é explicada com particular lucidez. Lá se afirma que "a preponderância da maioria, nas deliberações coletivas, somente se legitima quando todas as vontades deliberantes se manifestem, tendo em vista o interesse comum que as congregou”. Assim, "nas concordatas formadas por maioria de votos, os credores deliberam sob a pressão do seu interesse individual, deturpando o interesse coletivo da deliberação e tornando ilegítima a sujeição da minoria”.

$\mathrm{Na}$ tentativa de contornar esse problema, a Lei ${ }^{\circ} 11.101 / 2005$ resolveu dividir os credores em classes segundo a ordem de preferência de cada crédito, subordinando o resultado da deliberação da AGC à decisão individual de cada uma delas.

\footnotetext{
${ }^{220}$ O Tribunal de Justiça de São Paulo decidiu que não se pode dar interpretação extensiva ao art. 43 da LRF, a fim de atribuir a qualidade de subordinado ao crédito do chamado "controlador externo": "Agravo de instrumento - Recuperação judicial - Natureza de garantia prestada pela recuperanda - Classificação de crédito. Garantia prestada por sociedade por quotas de responsabilidade limitada à sua controladora, que dela possui aproximadamente noventa e oito por cento das quotas sociais, tem natureza empresarial, e não gratuita - Os bancos credores, não indicados no contrato social como administradores da controlada, não devem ter seus créditos classificados como subordinados. Agravo desprovido" (Câm. Fal. e Recup., AI nº 582.401-4/000, Rel. Des. Lino Machado, j. 1 $\left.{ }^{\circ} .4 .2009\right)$.
} 
Além de simplificar o processo de negociação (sobretudo para aprovação do plano de recuperação) ${ }^{221}$, esse sistema reconhece a pluralidade de interesses envolvidos no processo de insolvência, na medida em que confere aos grupos de credores representativos desses interesses poder de negociação entre si e com o devedor (mesmo que, em termos absolutos, não representem a maioria dos créditos). Sob essa perspectiva, a divisão em classes consistiria num instrumento de tutela ${ }^{222}$ dos credores.

Não é possível igualar, p. ex., a situação de credor com garantia real com a de credor quirografário: o primeiro, porque tem em determinado bem do devedor a segurança do recebimento do seu crédito, não tem estímulo a aceitar maiores riscos; já o segundo costuma ter mais interesse na recuperação do devedor, máxime quando o patrimônio deste apresentar-se insuficiente. Nessas circunstâncias, não se estabelece interesse comum a justificar a prevalência da vontade de um sobre a do outro.

221 Cf. GIUSEPPE BERSANI, “A previsão da subdivisão dos credores em classes foi - portanto substancialmente justificada em uma perspectiva de simplificação das tratativas entre o devedor e os credores, em vista de uma possível e preventiva adesão ao plano e da obtenção da maioria em sede de votação". Il concordato preventivo. Milão: Giuffrè, 2012, p. 254; tradução livre). No original: "La previsione della subdivisione dei creditori in classi è stata - quindi - sostanzialmente giustificata in una prospettiva di semplificazione delle tratative tra il debitor ed i creditori in vista di una possibile e preventiva adesione al piano e della formazione delle maggioranze in sede di votazione."

222 Cf. GIOVANNi BATTISTA NARDECCHIA, segundo o entendimento dominante na Itália, a divisão em classes consitui essencialmente um instrumento de tutela dos credores, com vistas a conferir legitimidade ao procedimento de aprovação do plano: "Nell'ambito dell'orientamento decisamente prevalente in dottrina, secondo cui le classi sono essenzialmente uno strumento di tutela dei creditori, vi è un'ulteriore distinzione tra chi individua il fine ultimo dell'istituto nella possibilità di consentire trattamenti differenziati tra creditori e chi ritiene che il classamento tuteli la formazione di maggioranze consapevoli e genuine, tali da legittimare il vincolo impostoai dissenzienti, impedendo, di fatto, che il debitore possa arbitrariamente alterare il procedimento de approvazione del concordato". (Gli effetti del concordato preventivo sui creditori. Milão: IPSOA, 2011, p. 83). Em sentido contrário, DANILO GALETTI afirma que "as classes não constituem um instrumento de proteção do crédito, mas uma facilidade concedida ao devedor com o fim de facilitar a aprovação da concordata, enquanto em um plano sem classes, votado por maioria, o devedor deveria convencer toda a plateia de credores quirografários da bondade da oferta, de modo a conseguir um número de votos suficiente para obter a aprovação da concordata." ("Classi obbligatorie? No grazie!”. Giurisprudenza di merito, 2010, n. 10, II, Giuffrè, p. 343 seg. Apud GIUSEPPE BERSANI. Il concordato preventivo... Op. cit..., p. 254; tradução livre). No original: "le classi non costituiscono uno strumento di tutela del creditore, ma un'agevolazione concessa al debitore al fine di facilitare l'approvazione del concordato, in quanto in un piano senza classi, pur votazione a maggioranza, il recorrente dovrebbe convincere tutta la platea dei creditori chirografari dela bontà dell'oferta, in modo da conseguire un numero di voti suficiente ad ottenere l'aprrovazioni del concordato".

${ }^{222}$ No original: "La actual ley otorga nuevo contenido a este principio al admitir la categorización de los acreedores, institución que no deja de lado la par condicio, sino que, por el contrario, intenta una recepción legal de la realidad económica para dotar de contenido material al proceso. Se busca así adecuar la diversidad negocial de los acreedores a una pauta de igualdad real y no meramente formal: la igualdad entre iguales, estándar axiológico tantas veces proclamado por nuestra Corte Suprema. El agrupamiento de los acreedores en categorías conforme al criterio de razonabilidad, y con la finalidad de formular propuestas de acuerdo diferencias, lejos está de violar el principio de igualdad, sino que, por el contrario, evita que se trate de modo idéntico a quienes son desiguales." (Ley de Concursos y Quiebras Comentada. 2 ed. Buenos Aires: AbeledoPerrot, 2009. t. 1, p. 29). 
A lei parte então do pressuposto de que os titulares de créditos com as mesmas características terão interesses mais ou menos homogêneos, de modo que a deliberação tomada no âmbito de classe (e que refletirá da decisão final da AGC) será dotada de maior legitimidade, constituindo verdadeira expressão do princípio da igualdade. A "categorização" dos credores consistiria, assim, decorrência lógica da par condicio creditorum, princípio máximo de justiça que orienta o processo concursal.

Nesse sentido, Francisco Junyent Bas e Carlos Molina Sandoval ${ }^{223}$ afirmam que a nova lei concursal argentina outorgou novo sentido ao princípio da par condicio creditorum ao admitir a categorização dos credores, com o objetivo de "acolher a realidade econômica para dotar o processo de conteúdo material”, buscando-se assim "adequar a realidade negocial dos credores a uma pauta de igualdade real e não meramente formal: a igualdade entre os iguais". Concluem ao final que:

"O agrupamento dos credores em categorias conforme o critério da razoabilidade, e com a finalidade de lhes formular propostas de acordo diferenciadas, longe está de violar o principio da igualdade, mas, ao contrário, evita que se trate de modo idêntico os que são desiguais."

Em síntese, a divisão dos credores em classes tem a finalidade de tornar o processo decisório mais democrático ${ }^{224} \mathrm{e}$, por conseguinte, produzir deliberações eficientes, justas e com maior aceitação entre os participantes, inclusive os vencidos, que mais bem representem a vontade da comunhão ${ }^{225}$.

\footnotetext{
${ }^{223}$ No original: "La actual ley otorga nuevo contenido a este principio al admitir la categorización de los acreedores, institución que no deja de lado la par condicio, sino que, por el contrario, intenta una recepción legal de la realidad económica para dotar de contenido material al proceso. Se busca así adecuar la diversidad negocial de los acreedores a una pauta de igualdad real y no meramente formal: la igualdad entre iguales, estándar axiológico tantas veces proclamado por nuestra Corte Suprema. El agrupamiento de los acreedores en categorías conforme al criterio de razonabilidad, y con la finalidad de formular propuestas de acuerdo diferencias, lejos está de violar el principio de igualdad, sino que, por el contrario, evita que se trate de modo idéntico a quienes son desiguales." (Ley de Concursos y Quiebras Comentada. 2 ed. Buenos Aires: AbeledoPerrot, 2009. t. 1, p. 29).

${ }^{224}$ Conforme o Deputado Osvaldo BIOLCHI, relator do projeto da Lei no 11.101/2005: “... conseguimos inserir a previsão dos arts. 41 e seguintes da lei, com a distribuição democrática da dispersão dos votos, na divisão das classes de credores, que detém poderes iguais e não dependerá só, por exemplo, do credor, da instituição financeira." (In: TOLEDO, Paulo Campos Salles de; e ABRÃO, Carlos Henrique (coords.). Comentários à Lei de Recuperação de Empresas e Falência. 5 ed. São Paulo: Saraiva, 2012, p. 47).

225 “O objetivo da divisão dos credores reunidos em Assembleia em classes é o de impedir distorções na formação da vontade da comunhão. Se os créditos de maior importância pertencem a credores de uma certa
} 


\subsection{Críticas ao modelo de divisão brasileiro}

Como se disse, o modelo de divisão dos credores em classes homogêneas tem o objetivo de contemplar os interesses de todos os envolvidos no processo, a fim de produzir deliberações mais democráticas. Além disso, presta-se a conferir legitimidade à imposição da vontade da maioria sobre a minoria, num ambiente em que a deliberação é tomada entre créditos com as mesmas prerrogativas e limitações.

Tendo em vista esses objetivos, critica-se o sistema brasileiro por ser extremamente simplista e excessivamente rígido, já que divide todos os possíveis credores em apenas três classes predeterminadas, sem permitir a formação de novas classes ou forma alternativa de divisão entre elas, e ainda por cima reúne numa mesma classe credores com interesses antagônicos, como ocorre com frequência na Classe III (que congrega credores quirografários e credores privilegiados ${ }^{226}$ ).

Ora, se o pressuposto ideológico da divisão dos credores em classes homogêneas é conferir legitimidade à imposição da vontade da maioria sobre a minoria, é evidente que reunião em uma mesma classe de créditos consideravelmente distintos resultará em decisões ilegítimas, com subversão à lógica do sistema.

É por isso que o Bankruptcy Code norte-americano elege, como critério obrigatório para a classificação e divisão dos credores em classes, a similaridade substancial entre os créditos. Para CHARLES JORDAN TABB ${ }^{227}$, a similaridade é fundamental

classificação, a indistinção em classes levaria à prevalência dos interesses deles, nem sempre conciliáveis com os das demais. Pois bem, a reunião numa mesma classe de credores com interesses divergentes representa a negativa desse objetivo" (FÁBIo UlhoA CoElHo. Comentários...Op. cit., p. 150).

226 "Ao distribuir os credores em classe, a lei incorreu num gravíssimo erro. Falo da inclusão, na mesma classe, dos credores quirografários e dos titulares de privilégio. Em tese, as classes deveriam agrupar os credores com interesses convergentes. (...) Os credores quirografários têm interesses diversos dos titulares de privilégio, especial ou geral. Enquanto estes últimos, exatamente por gozarem de preferência na falência, tendem a ser menos receptivos às propostas de alteração, novação ou renegociação de seus créditos no âmbito da recuperação judicial, os quirografários, em geral, se abrem mais facilmente a tais propostas. Isso porque a falência do devedor certamente impedirá que os quirografários tenham os seus créditos atendidos. Em outros termos, é muito diferente o risco de não recebimento do crédito que enfrentam os quirografários, de um lado, e os titulares de privilégio, de outro." (FÁBIo UlhoA COElHo. Comentários...Op. cit., p. 150).

${ }^{227}$ No original: "Similarity in legal entitlements is critical, since a class votes together (with dissenters bound by the class vote) and the same treatment must be afforded to each member of a class. It would be illogical and unfair to lump dissimilar claims or interest together and permit a binding unitary vote by nonunitary class." (The Law of Bankruptcy. Nova Iorque: The Foundation Press, 1997, p. 814-815). 
porque a classe vota em conjunto (com dissidentes vinculados ao voto da classe). De sorte que seria ilógico e injusto reunir créditos e direitos diferentes numa mesma classe e permitir um voto unitário vinculante de uma classe não-unitária (isto é, heterogênea).

Note-se que, nos Estados Unidos, compete ao proponente do plano de reorganização (normalmente o credor, dentro do prazo de exclusividade) designar as classes nas quais os credores serão divididos, segundo o critério da similaridade. Nesse sentido, prevê o §1122 do Bankruptcy Code que "o plano só poderá colocar um crédito ou direito em determinada classe se tal crédito ou direito for substancialmente similar aos demais créditos e direitos dessa mesma classe ${ }^{\text {228. }}$.

A similaridade, explica $\mathrm{TABB}^{229}$, é determinada em razão da natureza dos créditos ou direitos que estão sendo classificados. Em outras palavras, o que interessa é o caráter jurídico e o efeito do direito ou interesse em face do devedor. A natureza e identidade do seu titular é irrelevante, de modo que a mesma pessoa pode deter créditos ou direitos em mais de uma classe. A similaridade é assim aferida, principalmente, em razão da prioridade na ordem de pagamento dos credores na falência.

A Argentina possui norma semelhante à americana, estabelecendo que o devedor deve apresentar ao juiz uma proposta fundamentada de agrupamento e classificação dos credores em categorias, de acordo com natureza dos créditos "ou qualquer outro elemento que razoavelmente possa determinar sua agrupamento ou caracterização, a fim de poder lhes oferecer propostas diferenciadas de acordo preventivo”. No mínimo, a categorização deverá conter o agrupamento dos credores em

\footnotetext{
${ }^{228} \S 1122$. (a) Except as provided in subsection (b) of this section, a plan may place a claim or an interest in a particular class only if such claim or interest is substantially similar to the other claims or interests of such class. (b) A plan may designate a separate class of claims consisting only of every unsecured claim that is less than or reduced to an amount that the court approves as reasonable and necessary for administrative convenience.

${ }^{229}$ No original: "Similarity is determined by reference to the nature other claims or interests being classified. In other words, what matters is the legal character and effect or the holder is irrelevant. Indeed, the same entity might hold claims or interests in more than one class. (...) The similarity required is gauged primarily by the relative priority in payment against the debtor's assets enjoyed by the holder of the claim or interest". (The Law of Bankruptcy...Op. cit., p. 814-815).
} 
três classes: quirografários, trabalhistas (se existirem) e privilegiados, podendo haver subcategorias entre estes últimos ${ }^{230}$.

Assim também é na Alemanha. O art. 222 da Insolvenzordnung (InsO) prescreve a formação de tantos grupos quantos sejam os credores que se encontrem em situações jurídicas diferentes, admitindo-se, porém, que entre credores com idêntica situação jurídica sejam formados grupos de credores reunidos em virtude de interesses econômicos homogêneos, desde que a delimitação dos grupos seja adequada e que os critérios para determiná-la sejam indicados no plano $^{231}$.

Comum a todas essas leis é a preocupação com homogeneidade da composição das classes ou categorias de credores ${ }^{232}$, porque é ela que justifica a sujeição da minoria à decisão da maioria ${ }^{233}$. Tanto assim que conferem certa discricionariedade na formação dos grupos, desde que respeitados critérios de similaridade e razoabilidade, num

\footnotetext{
${ }^{230}$ Art. 41 da Ley $\mathrm{n}^{\circ}$ 24.522/95. Clasificación y agrupamiento de acreedores en categorías. Dentro de los diez (10) días contados a partir de la fecha en que debe ser dictada la resolución prevista en el artículo 36, el deudor debe presentar a la sindicatura y al juzgado una propuesta fundada de agrupamiento y clasificación en categorías de los acreedores verificados y declarados admisibles, la naturaleza de las prestaciones correspondientes a los créditos, el carácter de privilegiados o quirografarios, o cualquier otro elemento que razonablemente, pueda determinar su agrupamiento o categorización, a efectos de poder ofrecerles propuestas diferenciadas de acuerdo preventivo.
}

La categorización deberá contener, como mínimo, el agrupamiento de los acreedores en tres categorías: quirografarios, quirografarios laborales - si existieren - y privilegiados, pudiendo - incluso - contemplar categorías dentro de estos últimos.

231 (1) Bei der Festlegung der Rechte der Beteiligten im Insolvenzplan sind Gruppen zu bilden, soweit Beteiligte mit unterschiedlicher Rechtsstellung betroffen sind. Es ist zu unterscheiden zwischen 1. den absonderungsberechtigten Gläubigern, wenn durch den Plan in deren Rechte eingegriffen wird; 2. den nicht nachrangigen Insolvenzgläubigern; 3. den einzelnen Rangklassen der nachrangigen Insolvenzgläubiger, soweit deren Forderungen nicht nach $\S 225$ als erlassen gelten sollen; 4.den am Schuldner beteiligten Personen, wenn deren Anteils- oder Mitgliedschaftsrechte in den Plan einbezogen werden. (2) Aus den Beteiligten mit gleicher Rechtsstellung können Gruppen gebildet werden, in denen Beteiligte mit gleichartigen wirtschaftlichen Interessen zusammengefaßt werden. Die Gruppen müssen sachgerecht voneinander abgegrenzt werden. Die Kriterien für die Abgrenzung sind im Plan anzugeben. (3) Die Arbeitnehmer sollen eine besondere Gruppe bilden, wenn sie als Insolvenzgläubiger mit nicht unerheblichen Forderungen beteiligt sind. Für Kleingläubiger und geringfügig beteiligte Anteilsinhaber mit einer Beteiligung am Haftkapital von weniger als 1 Prozent oder weniger als 1000 Euro können besondere Gruppen gebildet werden. (traduzido a partir do espanhol).

${ }^{232}$ Para Charles JoRdAn TABB, a classificação dos créditos é central para o processo de confirmação do plano de reorganização. Afirma que é difícil exagerar a importância dessa classificação para a reorganização. No original: "Classification of claims and interests is central to the chapter 11 plan confirmation process. Indeed, it is difficult to overstate the importance of classification in chapter 11" (The Law of Bankruptcy...Op. cit., p. 813-814).

${ }^{233}$ Nesse sentido, GIUSEPPE BERSANI afirma que, se não efetuada corretamente a divisão das classes, isso poderá prejudicar gravemente o princípio da maioria, por força do qual se justifica a submissão dos credores dissidentes ou ausentes. (Il concordato preventivo... Op. cit., p. 259). 
reconhecimento de que a lei é incapaz de antecipar todas as possíveis conformações da comunhão de credores.

A lei brasileira, por outro lado, é contraditória ao sistema ao qual se filiou: divide os credores em classes, mas aceita que elas sejam formadas por créditos completamente distintos, quando não antagônicos ${ }^{234}$, inclusive com a reunião de credores privilegiados e quirografários. Pior: carece de instrumentos para evitar anomalias na formação dos grupos de credores, estabelecendo com injustificável rigidez a composição de cada uma das três classes.

\section{Funções e competência}

A Assembleia-Geral de Credores é de extrema importância no regime da Lei $\mathrm{n}^{\circ}$ 11.101/2005, à qual foi conferida competência para decidir matérias fundamentais ao processo de insolvência do devedor.

Diferente do que se passava na vigência do Decreto-Lei $n^{\circ} 7.661 / 45$, em que a atuação da AGC estava limitada à falência (a fim de deliberar forma alternativa de alienação dos ativos do devedor), agora ela também atua - e com papel decisivo - no processo da recuperação da empresa.

\subsection{Na recuperação judicial}

No processo da recuperação judicial, compete à Assembleia-Geral de Credores deliberar sobre as seguintes matérias: (i) aprovação, rejeição ou modificação do plano de recuperação judicial apresentado pelo devedor; (ii) a constituição do Comitê de Credores, a escolha de seus membros e sua substituição; (iii) o pedido de desistência do devedor; (iv) a escolha do gestor judicial, quando do afastamento do devedor; e (v) qualquer outra matéria que possa afetar os interesses dos credores (LRF, art. 35, I).

\footnotetext{
${ }^{234}$ Vislumbra-se, no direito brasileiro, maior dificuldade na aprovação do plano de recuperação em razão do agrupamento de credores em classes com interesses muitas vezes antagônicos que impede a apresentação de proposta única que atenda a todos os seus integrantes (RICARDO NEGRÃO. A eficiência do processo judicial na recuperação de empresa. São Paulo: Saraiva, 2010, p. 182).
} 
Restou vetada a alínea "c" do inciso I do art. 35, que outorgava à AGC a competência para deliberar "a substituição do administrador judicial e a indicação do substituto”. Entendeu-se que tal previsão seria incompatível com o parágrafo único do art. 23, que confere ao juiz a prerrogativa de destituir o administrador judicial e nomear seu substituto. Além disso, quis-se afastar a possibilidade da nomeação para o encargo de pessoa que não fosse da confiança do juízo ${ }^{235}$.

\subsubsection{Aprovação, rejeição ou modificação do plano de recuperação}

Sem dúvida, a competência mais relevante da AGC diz respeito à aprovação ou rejeição do plano de recuperação (LRF, art. 35, I, “a”). É essa decisão que sintetiza o espírito da Lei $\mathrm{n}^{\mathrm{o}}$ 11.101/2005, que conferiu aos credores soberania para decidir sobre a solução a ser dada à insolvência do devedor comum, oferecendo-lhes a recuperação judicial como forma de superação da crise, a fim de também permitir a manutenção da fonte produtora e do emprego dos trabalhadores, com a preservação da empresa e da sua função social e estímulo à atividade econômica (LRF, art. 47).

Nem sempre, porém, a AGC terá de ser convocada para a aprovação do plano de recuperação. No caso de nenhum credor ter oferecido impugnação ao plano apresentado pelo devedor, o juiz concederá a recuperação sem a convocação da AGC (LRF, art. 58); só haverá necessidade de deliberação da AGC se algum credor tiver feito objeção ao plano (LRF, art. 56). Neste caso, a assembléia deverá ser realizada em até 150 dias ${ }^{236}$ contados do deferimento do processamento da recuperação judicial ${ }^{237}$ (LRF, art. 56, § $1^{\circ}$ ).

\footnotetext{
${ }^{235}$ Eis as razões do veto presidencial: "As alíneas a e c atribuem à assembléia-geral de credores, dentre outras competências, a de deliberar sobre a substituição do administrador judicial e a indicação do seu substituto. Todavia tais disposições conflitam com o art. 52 (...). Verifica-se o conflito, também, no confronto entre esses dispositivos e o parágrafo único do art. 23 (...). Ao que parece, houve um equívoco do legislador ao mencionar o 'administrador judicial', parecendo que pretendeu se referir ao 'gestor judicial', uma vez que, ao prever a convocação da assembléia-geral de credores para deliberar sobre nomes, o projeto refere-se a este último, como se atesta da leitura do art. 65 (...). Há, portanto, no texto legal, um equívoco que merece ser sanado, elidindo-se a possibilidade de a lei vir a atribuir competências idênticas à assembléia-geral de credores e ao juiz da recuperação judicial ou da falência (..). Finalmente, impõe-se registrar que o veto afastará, de plano, a possibilidade de que seja nomeada para o encargo pessoa que não seja da confiança do juízo."

${ }^{236}$ MANOEL Justino BEZERRA critica, com razão, a exiguidade desse prazo. (Nova lei de... Op. cit., p. 166).

237 "A lei não estabeleceu, porém, nenhuma sanção para a hipótese de não ocorrer a assembleia dentro desse prazo, como, por exemplo, a imediata decretação da falência do devedor." (EDUARDo SECCHI MunHOZ. In: Comentários à lei de recuperação... Op. cit., p. 271).
} 
Note-se, ainda, que a competência da AGC não se limita à aprovação ou rejeição do plano originalmente apresentado, cabendo-lhe também aprovar modificações propostas pelo próprio devedor ou por algum credor $^{238}$. No segundo caso, porém, a eficácia dessas modificações dependerá necessariamente da concordância do devedor ${ }^{239}$. Além disso, são proibidas modificações que impliquem diminuição exclusivamente dos direitos dos credores ausentes à assembleia (LRF, art. 56, § $\left.3^{\circ}\right)$.

Não há, em regra, nenhum impedimento a que o plano de recuperação seja modificado até a data da realização da $\mathrm{AGC}^{240}$, mas desde que respeitado o princípio da publicidade e que os credores não sejam pegos de surpresa, isto é desde que a modificação do plano seja apresentada com tempo hábil para que os credores possam conhecer e analisar a proposta segundo os seus interesses ${ }^{241}$. Admitir-se o contrário seria negar os princípios de probidade e boa-fé objetiva que devem informar toda e qualquer negociação ${ }^{242}$, especialmente a realizada no bojo de um processo recuperação, que envolve interesses para além das partes "contratantes":

"Tem aumentado a prática de surpreender os credores com a apresentação de plano de recuperação distinto daquele alvo de anterior objeção. Um plano novo cai no colo dos credores no dia da assembleia, com pouco tempo para a sua efetiva apreciação. Trata-se de grave ofensa à boa-fé objetiva, segundo o qual, as tratativas e o

\footnotetext{
${ }^{238}$ Além disso, na mesma assembleia convocada para deliberar sobre o plano de recuperação, poderá ser constituído o Comitê de Credores, caso já não tenha sido formado (LRF, art. 56, $\S 2^{\circ}$ ).

${ }^{239}$ Ponto criticado em nossa legislação, conforme exposto no Capítulo 2, item 3.2.

240 “A doutrina e a jurisprudência não discrepam quanto à possibilidade de se alterar o plano de recuperação judicial apresentado pelo devedor no prazo previsto no art. 53, inexistindo qualquer limitação à permissão de modificação do plano originalmente proposto até a data da realização da assembleia-geral de credores. Por isso mesmo, o $\S 3^{\circ}$ do art. 56 preceitua que 'o plano de recuperação judicial poderá sofrer alterações na assembleia-geral, desde que haja expressa concordância do devedor e em termos que não impliquem diminuição dos direitos exclusivamente dos credores ausentes'." (TJSP, $1^{\text {a }}$ Câm. de Dir. Empresarial, AI no 0114685-06.2012.8.26.0000, Rel. Des. Pereira Calças, j. 30.10.2012).

241 “Agravo. Recuperação Judicial. Alteração substancial e profunda do plano de recuperação judicial proposta sem observância de publicidade com antecedência razoável para o comparecimento de todos os credores. Vulneração dos princípios da lealdade, confiança e boa-fé objetiva. Natureza contratual da recuperação judicial que exige, na fase pré-contratual, conduta proba, honesta e ética, sob pena de afronta à boa-fé objetiva do art. 421 do Código Civil. A liberdade de contratar deve ser exercida sob a luz da função social da recuperação judicial. Inteligência do art. 421 do Código Civil. Apelo provido para anular a Assembleia-Geral, ordenando-se convocação de outro conclave no qual, o plano, observe as regras do art. 53 da Lei no 11.101/2005” (TJSP, Câm. Fal. e Recup., AI nº 0493696-79.2010.8.26.0000, j. 18.10.2011).

242 Conforme preceitua o art. 422 do Código Civil, “os contratantes são obrigados a guardar, assim na conclusão do contrato, como em sua execução, os princípios de probidade e boa-fé”.
} 
plano de recuperação judicial, segundo a jurisprudência emanada da Câmara Reservada é um contrato vinculam as partes do negócio. Esse comportamento, além de ofender a boa-fé objetiva, traz efeitos deletérios para o instituto da recuperação judicial, cuja imagem fica comprometida. É preciso cuidar também da saúde moral do instituto" (ALBERTO CAMIÑ MOREIRA ${ }^{243}$ ).

Apesar da divergência doutrinária a respeito ${ }^{244}$, tem-se ainda admitido que as modificações ao plano sejam deliberadas pela AGC não apenas na fase anterior à recuperação, como decorre da literalidade do art. 56, § $3^{\circ}$, da LRF, mas igualmente depois da sua concessão, como forma de atender a eventuais intercorrências ou circunstâncias capazes de comprometer a execução do plano na forma em que originalmente aprovado ${ }^{245}$.

\footnotetext{
${ }^{243}$ Parecer dado na qualidade de Procurador de Justiça extraído do acórdão do agravo de instrumento referido na nota acima.

${ }^{244}$ Admitindo a modificação do plano depois da concessão da recuperação, assim se manifesta FÁBIO ULHOA CoElHO: "Em princípio, é imutável esse plano. Se o beneficiado dele se desviar, corre o risco de ter a sua falência decretada. Não pode, porém, a lei ignorar a hipótese de revisão do plano de recuperação, sempre que a condição econômico-financeira do devedor passar por considerável mudança. Nesse caso, admite-se o aditamento do plano de recuperação judicial, mediante retificação pela Assembléia de Credores. A retificação está sujeita ao mesmo quórum qualificado de deliberação previsto para a aprovação do plano original. Se pretender o aditamento, o beneficiado deve aduzir requerimento acompanhado da exposição circunstanciada dos fatos que fundamentam a revisão do plano". (Comentários... Op. cit., p. 241)".
}

No mesmo sentido é a opinião de CARLOS KLEIN ZANINI: "De início, impõe-se ter presente que a própria lei admite a possibilidade de o Plano, mesmo depois de aprovado, vir a experimentar modificações por deliberação da Assembléia-Geral. É o que consta do art. 35, I, alínea $a$. Nada impede, portanto - antes recomenda-se -, promova o magistrado a convocação da Assembléia-Geral de Credores a fim de submeter à sua apreciação eventual descumprimento, ocorrido ou iminente, que poderá ser sanado mediante a modificação do Plano" (In: Comentários... Op. cit., p. 328).

Em sentido contrário, opondo-se a modificação do plano depois de concedida a recuperação, confira-se a lição JORGE LOBO: "O plano de recuperação judicial, aprovado pela assembléia geral de credores (art. 58, caput), e homologado por sentença (art. 59, $\S 1^{\circ}$ ), somente poderá ser alterado por decisão, proferida em grau de recurso, em agravo que tiver sido interposto por qualquer credor e pelo Ministério Público (art. 59, $\left.\$ 2^{\circ}\right)$. Permitir que a assembléia geral de credores reveja, reexamine e modifique o plano, transformando-o em título executivo judicial pela sentença concessiva da recuperação, é criar uma instância não contemplada na LRE, ferir o princípio da estabilidade e da segurança jurídicas e negar vigência ao art. 73, IV" (Comentários...Op. cit., p. 215).

${ }^{245}$ Nos Estados Unidos, a modificação do plano aprovado é medida excepcional. Ressalvado o caso de o devedor ser pessoa física, a modificação só é admitida se ainda não tiver havido a consumação substancial do plano aprovado. Essa consumação substancial, que se dá logo no início da execução do plano, opera-se com: (i) a transferência de todos ou quase todos os bens cuja alienação estiver prevista no plano; (ii) a assunção pelo devedor ou seu sucessor dos negócios ou da administração de toda (ou quase toda) propriedade versada no plano; e (iii) o começo da distribuição de pagamentos segundo o plano. Ainda assim, mesmo que não tenha havido consumação substancial, só poderá haver modificação do plano se o tribunal, depois de notificados os credores e realizada audiência, se convencer que as circunstâncias justificam a modificação (Bankruptcy Code, § 1127(b) c.c. § 1101). 
Concessa venia, não se vislumbra razão para vedar-se a modificação ao plano após a concessão da recuperação quando houver concordância de todos os credores afetados, até por constituir expressão da autonomia da vontade. Por outro lado, não parece razoável sujeitar os credores dissidentes da modificação à vontade da maioria depois que o plano original já tenha sido aprovado.

Quando o primeiro plano é deliberado, a negociação tem por base as condições originais dos créditos, com todas as suas prerrogativas e limitações. Com a recuperação, alteram-se essas condições por meio de novação (LRF, art. 59) ${ }^{246}$, de modo que as forças entre os credores também se alteram. Um credor com garantia real, p.ex., a quem a recuperação pouco interessava, pode ter concordado com a aprovação do plano mediante o pagamento de juros maiores ou em menos prestações. Já o credor quirografário poderá ter aceitado, ante o risco de nada receber, um abatimento em cinquenta por cento ou mais do seu crédito. Logicamente, uma nova deliberação nessas condições poderá gerar flagrantes distorções, além de inegável injustiça.

Assim, a modificação do plano depois da sua aprovação, ao menos em princípio, somente poderá afetar os credores que com ela concordarem, ressalvadas hipóteses excepcionalíssimas, consistentes em eventos imprevisíveis que comprometam significativamente o cumprimento do plano, e desde que a alteração não cause prejuízo aos credores.

De qualquer forma, depois de decorrido o prazo máximo de dois anos em que o devedor permanece em recuperação (LRF, art. 61) ${ }^{247}$, ou seja, a partir de quando o devedor não mais estiver em "estado de recuperação judicial”, a eventual aprovação pela AGC de modificação ao plano é ineficaz em relação aos credores que não a tenham aceitado, conforme já decidiu o Tribunal de Justiça de São Paulo no caso da recuperação judicial da PARMALAT ${ }^{248}$ :

\footnotetext{
${ }^{246}$ Art. 59. O plano de recuperação judicial implica novação dos créditos anteriores ao pedido, e obriga o devedor e todos os credores a ele sujeitos, sem prejuízo das garantias, observado o disposto no $\S 1^{\circ}$ do art. 50 desta Lei.

${ }^{247}$ Art. 61. Proferida a decisão prevista no art. 58 desta Lei, o devedor permanecerá em recuperação judicial até que se cumpram todas as obrigações previstas no plano que se vencerem até 2 (dois) anos depois da concessão da recuperação judicial.

${ }^{248}$ Câm. reservada à Fal. e à Recup., AI no 994.09.282061-9, Rel. Des. Pereira Calças, j. 4.5.2010.
} 
"No caso da PARMALAT o biênio judicial já transcorreu há muito tempo, mas o Juiz ainda não decretou por sentença o encerramento da recuperação judicial, consoante determina o art. 63, porque, conforme anota o senhor administrador judicial, ainda existem recursos e pendências a serem solucionadas.

Com a devida vênia, entendo que o processo de recuperação judicial da PARMALAT já deveria ter sido encerrado por sentença judicial, cumprindo-se rigorosamente o art. 63, que de forma imperativa preconiza: "o juiz decretará por sentença o encerramento da recuperação". Malgrado a determinação da lei, não cumprida, o processo de recuperação judicial da PARMALAT continua tramitando em Juízo. Em razão disso, a PARMALAT requereu convocação de assembleia geral de credores para propor alteração do plano judicial, notadamente a forma de pagamento de seus credores e autorização para a alienação judicial da unidade produtiva de Carazinhos.

Em rigor, o magistrado deveria ter indeferido o pleito, haja vista que o plano aprovado e concedida a recuperação judicial por sentença transitada em julgado, deveria a PARMALAT cumprir rigorosamente o plano de recuperação judicial, sob pena de ser a recuperação convolada em falência, conforme determina o $\S 1^{\circ}$ do artigo 61. (...)

$\mathrm{Na}$ medida em que se permitiu, neste caso, a convocação de assembléia-geral de credores para se alterar o plano de recuperação aprovado anteriormente e homologado por sentença transitada em julgado, indaga-se: a alegada soberania da assembléia-geral de credores tem o poder de afrontar o ato jurídico perfeito (contrato) e a coisa julgada, e modificar o direito dos credores que não concordam com a modificação do plano que afeta o direito adquirido de receber seu crédito na forma e condições do plano original? (...)

Em suma, os credores que concordaram com a modificação das condições de pagamento de seus créditos previstas no plano anterior, em face da autonomia da vontade, submetem-se às novas condições. No entanto, os credores que não concordaram expressamente com as modificações pleiteadas pela PARMALAT, têm o direito de propor a execução específica ou a falência da devedora com base no art. 94, conforme expressa previsão do art. 62 da LRF."

Em caso de rejeição do plano pela AGC, dispõe o art. 56, $\S 4^{\circ}$, da LRF que o juiz decretará a falência do devedor. No mesmo sentido, o art. 73 prescreve que o juiz decretará a falência durante o processo de recuperação judicial quando houver sido rejeitado o plano de recuperação, nos termos do $\S 4^{\circ}$ do art. 56. A propósito do assunto, remete-se às ponderações feitas no Capítulo II, itens 3.2 e 3.6. 


\subsubsection{Constituição do Comitê de Credores}

Também compete à AGC a constituição do Comitê de Credores, bem como a escolha e substituição dos seus membros (LRF, art. 35, I, “b”).

Para a doutrina, o Comitê de Credores é um órgão facultativo ${ }^{249} \mathrm{de}$ representação dos credores na falência e na recuperação judicial, com funções administrativas e de fiscalização (LRF, art. 27) ${ }^{250}$. Não tem, todavia, a capacidade de substituir a atuação individual dos credores ${ }^{251}$, atribuindo-se-lhe a função de auxiliá-los e proteger seus interesses comuns.

Tanto no processo de recuperação judicial quanto no de falência, compete ao Comitê, fundamentalmente, (i) fiscalizar as atividades e examinar as contas do administrador judicial, (ii) zelar pelo bom andamento do processo e pelo cumprimento da lei, (iii) comunicar ao juiz, caso detecte violação dos direitos ou prejuízo aos interesses dos credores, (iv) apurar e emitir parecer sobre quaisquer reclamações dos interessados, (v) requerer ao juiz a convocação da Assembleia-Geral de Credores, e (vii) manifestar-se nas hipóteses previstas na lei, como para impugnar a relação de credores apresentada pelo administrador judicial (LRF, art. $\left.8^{\circ}\right)^{252}$, dizer sobre as habilitações e impugnações de crédito (LRF, art. 12) ${ }^{253}$, ou pedir a exclusão, outra classificação ou a retificação de

${ }^{249}$ Cf. Julio Kahan MAndel. Nova lei de falências e recuperação de empresas anotada. São Paulo: Saraiva, 2005, p. 64.

${ }^{250}$ Não havendo Comitê de Credores, caberá ao administrador judicial ou, na incompatibilidade deste, ao juiz exercer suas atribuições (LRF, art. 28).

251 “Tem por escopo primordial a fiscalização, o acompanhamento do processo e a proteção dos interesses gerais de seus representados. Esse órgão não substitui a atuação individual dos credores, mas atua $a d$ adjuvandum tantum, isto é, auxiliando a atuação de cada qual no que se relaciona com o interesse comum de todos eles para lhes permitir um acompanhamento mais eficaz dos atos do processo concursal (de falência e de recuperação judicial), com atribuições deliberativas e, excepcionalmente, executivas" (ALFREDO ASSIS GonÇALVES NETO. In: CORREAA-LIMA, Osmar Brina; e LIMA, Sérgio Mourão Correa (coords.). Comentários à nova Lei de Falência e Recuperação de Empresa. Rio de Janeiro: Forense, 2009, p. 197-198).

252 Art. $8^{\circ}$. No prazo de $10(\mathrm{dez})$ dias, contado da publicação da relação referida no art. $7^{\circ}, \S 2^{\circ}$, desta Lei, o Comitê, qualquer credor, o devedor ou seus sócios ou o Ministério Público podem apresentar ao juiz impugnação contra a relação de credores, apontando a ausência de qualquer crédito ou manifestando-se contra a legitimidade, importância ou classificação de crédito relacionado.

${ }^{253}$ Art. 12. Transcorrido o prazo do art. 11 desta Lei, o devedor e o Comitê, se houver, serão intimados pelo juiz para se manifestar sobre ela [impugnações, habilitações e contestações] no prazo comum de 5 (cinco) dias. 
qualquer crédito, nos casos de descoberta de falsidade, dolo, simulação, fraude ou erro essencial (LRF, art. 19) ${ }^{254}$.

O órgão também possui algumas funções pertinentes apenas ao processo da recuperação judicial, como a fiscalização da administração das atividades do devedor (com a apresentação de relatórios mensais) e da execução do plano, cabendo-lhe ainda submeter à autorização do juiz, quando ocorrer o afastamento do devedor nas hipóteses do art. 64 da LRF, a alienação de bens do ativo permanente, a constituição de ônus reais e outras garantias, bem como atos de endividamento necessários à continuação da atividade empresarial durante o período que antecede a aprovação do plano de recuperação judicial.

As decisões do Comitê são tomadas por maioria, devendo ser consignadas em livro de atas. Caso não seja possível a obtenção de maioria em deliberação do Comitê (p. ex., quando seus dois únicos membros votarem em sentido oposto, ou, havendo três membros, um deles tenha se abstido de votar), o impasse será resolvido pelo administrador judicial ou, na incompatibilidade deste, pelo juiz (LRF, art. 27, § $1^{\circ}$ e $2^{\circ}$ ).

Alfredo Assis GonÇAlves Neto, conquanto reconheça que o Comitê de Credores e Assembleia-Geral de Credores sejam formados a partir do "interesse coletivo da comunhão dos credores", distingue esses dois órgãos porque enquanto a AGC tem o escopo de definir qual seja o interesse comum, o comitê é criado para proteger esse interesse nos processos de recuperação judicial e falência, “controlando e fiscalizando os atos neles praticados, alertando sobre as omissões no cumprimento da lei, das determinações judiciais e assembleares e, excepcionalmente, quando a tanto legitimado, adotando providências concretas na defesa desses mesmos interesses”.

\footnotetext{
${ }^{254}$ Art. 19. O administrador judicial, o Comitê, qualquer credor ou o representante do Ministério Público poderá, até o encerramento da recuperação judicial ou da falência, observado, no que couber, o procedimento ordinário previsto no Código de Processo Civil, pedir a exclusão, outra classificação ou a retificação de qualquer crédito, nos casos de descoberta de falsidade, dolo, simulação, fraude, erro essencial ou, ainda, documentos ignorados na época do julgamento do crédito ou da inclusão no quadro-geral de credores.
} 
Nos termos do art. 26 da LRF, o Comitê de Credores será constituído por deliberação isolada de qualquer das classes de credores na Assembleia-Geral ${ }^{255}$ e terá a seguinte composição: 1 (um) representante indicado pela classe de credores trabalhistas, com 2 (dois) suplentes; 1 (um) representante indicado pela classe de credores com direitos reais de garantia ou privilégios especiais, com 2 (dois) suplentes; e 1 (um) representante indicado pela classe de credores quirografários e com privilégios gerais, com 2 (dois) suplentes.

A composição das classes indicadas no art. 26 da LRF é ligeiramente distinta daquela prevista no art. 41 (que vale para todas as demais matérias de competência dessa instância deliberativa). Para a formação do Comitê, os credores com privilégios especiais foram colocados na mesma classe dos credores com garantia real, enquanto que, nas demais deliberações, os credores dotados de garantia real permanecem sozinhos numa única classe (Classe II), reunindo os credores com privilégios especiais na mesma classe dos credores quirografários, com privilégio geral e subordinados (Classe III).

Essa incongruência legislativa é explicada ${ }^{256}$ em razão de uma imprecisão da emenda que alterou a redação do art. 41, isolando os credores com garantia real na Classe II, mas sem proceder à mesma alteração no art. 26. Tão flagrante o equívoco que Paulo F. C. Salles de Toledo chega a propor que, mesmo para a constituição do Comitê, seja adotado o modelo de divisão previsto no art. 41:

"A solução talvez esteja em, desconsiderando os incisos I a III do art.
26 - e com isso, superando as incongruências acima apontadas,
entender que o comitê será formado por um representante e dois
suplentes de cada classe, como estas se encontram definidas no
dispositivo específico sobre a matéria (art. 41 da LRE). É claro que o
aplicador da lei, ao assim agir, estará pondo de lado o princípio
segundo o qual a norma jurídica não tem palavras inúteis. Ele estará,
no entanto, desse modo, levando em conta a finalidade do dispositivo
e dando-lhe interpretação sistemática e, com isso, acima de tudo,
tornando-o aplicável. Lembre-se, a respeito, que o juiz não pode
eximir-se de 'sentenciar ou despachar alegando lacuna ou obscuridade
da lei'”.

${ }^{255} \mathrm{Na}$ escolha dos representantes de cada classe no Comitê de Credores, somente os respectivos membros poderão votar (LRF, art. 44).

${ }^{256}$ Cf. Fábio UlhoA Coelho (Comentários... Op. cit., p. 114). 
Em que pesem os judiciosos argumentos, não parece possível, neste caso, simplesmente ignorar a previsão do art. 26. Conforme exposto alhures, a rígida divisão feita do art. 41 é igualmente arbitrária, reunindo numa mesma classe créditos com características absolutamente distintas. Não existe, por isso, razão para que se prefira a divisão do art. 41 à do art. 26. Se se deve respeitar a divisão arbitrária da lei, então há de prevalecer, in casu, o princípio da especialidade ${ }^{257}$.

Assim, se qualquer das classes de credores previstas no art. 26 aprovar a constituição do Comitê e eleger o seu representante ${ }^{258}$ em Assembleia-Geral, o órgão será formado, conferindo-se às demais classes a faculdade de eleger os seus respectivos representantes. Diz-se faculdade porque as classes não são obrigadas a indicar membros para o Comitê, que poderá funcionar até com um único componente ${ }^{259}$, conforme prevê o parágrafo primeiro do art. 26 da $\mathrm{LRF}^{260}$.

No caso de o Comitê já ter sido formado por deliberação da AGC, a classe que nele ainda não estiver representada poderá, mediante requerimento escrito dos titulares da maioria dos créditos, requerer ao juiz a nomeação do seu representante e dos suplentes, independentemente da realização de nova assembleia. O mesmo também vale para a substituição do representante eleito ou dos suplentes (LRF, art. 26, § $2^{\circ}$, I e II). Note-se, porém, que a lei só dispensa a deliberação assemblear quando a constituição do Comitê já tiver sido aprovada pela AGC.

257 "Sublinhe-se, uma vez mais, que as classes de credores previstas no art. 26, I, II e III - para eleição do Comitê de Credores - são diversas das classes previstas no art. 41. Para aquela eleição, portanto, prevalece a disposição especial do art. 26." (ERASMO VALlADÃo FrAnÇA. In: Comentários... Op. cit., p. 212).

${ }^{258}$ Contudo, não poderá integrar o Comitê quem, nos últimos 5 (cinco) anos, no exercício do cargo de administrador judicial ou de membro do Comitê em falência ou recuperação judicial anterior, foi destituído, deixou de prestar contas dentro dos prazos legais ou teve a prestação de contas desaprovada. Além disso, também ficará impedido de integrar o Comitê quem tiver relação de parentesco ou afinidade até o terceiro grau com o devedor, seus administradores, controladores ou representantes legais ou deles for amigo, inimigo ou dependente (LRF, art. 30, caput e $\S 1^{\circ}$ ).

259 “... não é razoável que (...) deixem os credores, aos quais a LRF atribuiu papel tão relevante, de exercer seus direitos por meio de órgão criado pela lei exatamente para tornar eficaz a participação deles. Plenamente justificável, portanto, que, mesmo se houver uma única classe de credores, possam eles ser representados no concurso pelo órgão com atribuições legalmente definidas, a que se deu o nome de "comitê"” (PAUlO. F. C. SAlles DE TOLEDO. Comentários à Lei de Recuperação de Empresas e Falência. 5 ed. São Paulo: Saraiva, 2012, p. 124).

260 Art. 26 (...). $\S 1^{\circ}$. A falta de indicação de representante por quaisquer das classes não prejudicará a constituição do Comitê, que poderá funcionar com número inferior ao previsto no caput deste artigo. 


\subsubsection{O pedido de desistência do devedor}

O requerimento da recuperação é feito por petição, a ser instruída com as informações e documentos referidos no art. 51 da LRF. Estando em termos a documentação, o juiz deferirá o processamento da recuperação judicial, que gera os efeitos $^{261}$ especificados no art. 52, notadamente a suspensão das ações ou execuções contra o devedor ${ }^{262}$.

A partir de então ${ }^{263}$, isto é, uma vez deferido o processamento da recuperação ${ }^{264}$, o devedor não poderá desistir do pedido de recuperação judicial, salvo se obtiver aprovação da desistência na Assembleia-Geral de Credores (art. 52, § $4^{\circ}$ ).

Para RACHEL SZTAJN ${ }^{265}$, “ao se impor a concordância da Assembléia-Geral de Credores, sujeita-se o que seria uma declaração unilateral à condição suspensiva”, de modo que os efeitos do pedido dependerão da anuência dos credores. Assim,

\footnotetext{
${ }^{261}$ Art. 52. Estando em termos a documentação exigida no art. 51 desta Lei, o juiz deferirá o processamento da recuperação judicial e, no mesmo ato: I - nomeará o administrador judicial, observado o disposto no art. 21 desta Lei; II - determinará a dispensa da apresentação de certidões negativas para que o devedor exerça suas atividades, exceto para contratação com o Poder Público ou para recebimento de benefícios ou incentivos fiscais ou creditícios, observando o disposto no art. 69 desta Lei; III - ordenará a suspensão de todas as ações ou execuções contra o devedor, na forma do art. $6^{\circ}$ desta Lei, permanecendo os respectivos autos no juízo onde se processam, ressalvadas as ações previstas nos $\S \S 1^{\circ}, 2^{\circ}$ e $7^{\circ}$ do art. $6^{\circ}$ desta Lei e as relativas a créditos excetuados na forma dos $\S \S 3^{\circ}$ e $4^{\circ}$ do art. 49 desta Lei; IV - determinará ao devedor a apresentação de contas demonstrativas mensais enquanto perdurar a recuperação judicial, sob pena de destituição de seus administradores; V - ordenará a intimação do Ministério Público e a comunicação por carta às Fazendas Públicas Federal e de todos os Estados e Municípios em que o devedor tiver estabelecimento.

${ }^{262}$ Salvo as ações que demandarem quantia ilíquida, as ações de natureza trabalhista até a apuração do respectivo crédito, as execuções fiscais e as ações relativas aos créditos excetuados na forma dos $\S \S 3^{\circ}$ e $4^{\circ}$ do art. 49 (LRF, art. $6^{\circ}, \S \S 1^{\circ}, 2^{\circ}$ e $7^{\circ}$ e 52 , III).

263 "Entre o ajuizamento da petição inicial e o deferimento do processamento da recuperação, o devedor tem assegurado o direito potestativo de desistir da ação". (JORGE LOBO. In: Comentários... Op. cit., p. 203).

${ }^{264}$ Que não se confunde com a concessão da recuperação: "O despacho de processamento não se confunde também com a decisão concessiva da recuperação judicial. O pedido de tramitação é acolhido no despacho de processamento, em vista apenas de dois fatores - a legitimidade ativa da parte requerente e a instrução nos termos da lei. Ainda não está definido, porém, que a empresa do devedor é viável e, portanto, ele tem direito ao benefício. Só na tramitação do processo, ao longo da fase deliberativa, fornecerá os elementos para a concessão da recuperação judicial" (FÁBIO UlHOA COElHO. Comentários... Op. cit., p. 214).
}

265 In: SOUZA JÚNIOR, Francisco Satiro de; e PITOMBO, Antônio Sérgio de Moraes (Coords.). Comentários à Lei de Recuperação de Empresas e Falência. São Paulo: Revista dos Tribunais, 2005, p. 263. 
"uma vez deferido o processamento do pedido, o devedor terá de explicar aos credores, de forma convincente, suportados seus argumentos sobre fatos ou elementos indicativos da possibilidade de preservar a atividade, que o melhor resultado para os interesses está na desistência do procedimento mantendo-se relações jurídicas entre as partes, tal como originalmente ajustadas. Se o pedido de recuperação judicial constitui uma estratégia destinada a facilitar a preservação dos negócios, a desistência do devedor deve ser entendida como nova estratégia, daí o interesse em indagar o que teria ocorrido entre o momento em que o pedido de recuperação judicial foi apresentado e seu deferimento, que justifique (ou explique), a mudança de rumo".

Mas uma vez concedida a recuperação, nos termos do art. 58 da LRF, não cabe mais a desistência do pedido ${ }^{266}$. Mesmo havendo requerimento nesse sentido, a Assembleia-Geral de Credores nem deverá ser convocada.

\subsubsection{A escolha do gestor judicial}

Na vigência do Decreto-Lei $n^{0} 7.661 / 45$, o devedor em concordata continuava à frente do seu negócio, embora sob a fiscalização do comissário e atuando limitadamente, dependendo de autorização judicial para a prática de atos que pudessem implicar comprometimento do patrimônio (art. 167).

Via de regra, esse sistema (conhecido como "debtor in possession”) se mantém no regime Lei $\mathrm{n}^{\circ} 11.101 / 2005$, cujo art. 64 estabelece que, "durante o procedimento da recuperação judicial, o devedor ou seus administradores serão mantidos na condução da atividade empresarial, sob fiscalização do Comitê, se houver, e do administrador judicial”.

O novo diploma inovou em relação ao anterior ao estabelecer que o devedor ou seus administradores serão afastados da direção da empresa se verificada quaisquer das hipóteses previstas no art. 64 da $\mathrm{LRF}^{267}$, relativas a casos de crime, fraude, negligência ou grave incompetência administrativa.

\footnotetext{
266 "se a concessão da recuperação pressupõe seu deferimento prévio, dessome-se (sic.) que o devedor não poderá formular desistência da recuperação mesmo após sua concessão" (MARIO SERGIO MILANI. Lei de Recuperação judicial... Op. cit., p. 246).

267 Art. 64. Durante o procedimento de recuperação judicial, o devedor ou seus administradores serão mantidos na condução da atividade empresarial, sob fiscalização do Comitê, se houver, e do administrador
} 
Destituído o administrador, dispõe o parágrafo único do art. 64 que será ele "substituído na forma prevista nos atos constitutivos do devedor ou do plano de recuperação judicial”.

Por outro lado, na hipótese de afastamento do devedor, compete à AssembleiaGeral de Credores ${ }^{268}$ eleger um "gestor judicial”, que assumirá a administração das atividades do devedor (LRF, art. 65): "Quando do afastamento do devedor, nas hipóteses previstas no art. 64 desta Lei, o juiz convocará a assembléia-geral de credores para deliberar sobre o nome do gestor judicial que assumirá a administração das atividades do devedor, aplicando-se-lhe, no que couber, todas as normas sobre deveres, impedimentos e remuneração do administrador judicial”.

Controverte-se acerca do conceito de "devedor" para efeito de aplicação dos arts. 64 e 65 da LRF e da nomeação do gestor judicial, cuidando-se de matéria relevante para compreender a extensão dos poderes da Assembleia-Geral de Credores.

Da interpretação literal e conjugada dos arts. 65 e 190 da LRF ${ }^{269}$, infere-se que a expressão "devedor" compreende (i) o empresário individual, (ii) a sociedade empresária e (iii) os sócios ilimitadamente responsáveis, concluindo-se que o gestor judicial poderia ser nomeado no caso de afastamento de qualquer um deles.

\footnotetext{
judicial, salvo se qualquer deles: I - houver sido condenado em sentença penal transitada em julgado por crime cometido em recuperação judicial ou falência anteriores ou por crime contra o patrimônio, a economia popular ou a ordem econômica previstos na legislação vigente; II - houver indícios veementes de ter cometido crime previsto nesta Lei; III - houver agido com dolo, simulação ou fraude contra os interesses de seus credores; IV - houver praticado qualquer das seguintes condutas: a) efetuar gastos pessoais manifestamente excessivos em relação a sua situação patrimonial; b) efetuar despesas injustificáveis por sua natureza ou vulto, em relação ao capital ou gênero do negócio, ao movimento das operações e a outras circunstâncias análogas; c) descapitalizar injustificadamente a empresa ou realizar operações prejudiciais ao seu funcionamento regular; d) simular ou omitir créditos ao apresentar a relação de que trata o inciso III do caput do art. 51 desta Lei, sem relevante razão de direito ou amparo de decisão judicial; V - negar-se a prestar informações solicitadas pelo administrador judicial ou pelos demais membros do Comitê; VI - tiver seu afastamento previsto no plano de recuperação judicial.

${ }^{268}$ Enquanto não nomeado o gestor, suas funções serão exercidas, em caráter provisório, pelo administrador judicial (LRF, art. 65, § $1^{\circ}$ ).

${ }^{269}$ Art. 190. Todas as vezes que esta Lei se referir a devedor ou falido, compreender-se-á que a disposição também se aplica aos sócios ilimitadamente responsáveis.
} 
Contudo, para Haroldo Malheiros Duclerc Verçosa, o termo devedor constante do art. 65 se refere única e exclusivamente ao empresário individual ${ }^{270}$, ao passo que, para EDUARDO SECCHI MUNHOZ, ele também compreenderia a sociedade empresária, assim identificada na figura do seu sócio controlador, que é o empresário ${ }^{271}$.

Para o primeiro, não caberia a nomeação de gestor judicial em recuperação judicial de sociedade empresária (mas tão somente o afastamento e substituição dos seus administradores, na forma do art. 64, par. único); para o segundo, o gestor seria nomeado em substituição ao sócio controlador, passando a conduzir os negócios sociais a partir da estrutura societária. Assim, seriam resguardados os interesses e prerrogativas dos sócios não-controladores, sem responsabilidade pelos atos de má gestão imputáveis ao controlador:

\begin{abstract}
"Se a interpretação do artigo for no sentido de que, mesmo no caso da sociedade empresária, esta é que deve ser afastada, e não o seu sócio controlador, os sócios não controladores desta serão prejudicados, na medida em que não terão nenhuma vinculação, a partir desta data, com o desenvolvimento da atividade empresarial, que passará a ser conduzida pelo gestor judicial nomeado pela assembléia geral de credores. Entendendo-se, por outro lado, que a lei pretendeu referir-se ao sócio controlador, como parece mais correto pelas razões anteriormente alinhadas, o gestor judicial assume a posição de controle, exercendo suas prerrogativas, portanto, de dentro da estrutura societária, sem afetar, dessa forma, o interesse dos sócios não-controladores. Nesse caso, o poder de controle será detido pelo gestor nomeado pela assembléia geral de credores, que deverá exercêlo no interesse não apenas destes, mas também dos sócios da sociedade devedora" (Eduardo Secchi Munhoz) ${ }^{272}$.
\end{abstract}

\footnotetext{
270 “...quando se examina particularmente o art. 64 da LRF entende-se sem qualquer sombra de dúvida que o termo devedor significa ali empresário (individual), e jamais sociedade empresária, sendo impossível assimila-lo ao controlador" ("O status jurídico do controlador e dos administradores na recuperação judicial" Revista de Direito Mercantil Industrial, Econômico e Financeiro, São Paulo, n. 143, p. 34).

271 "Se faz algum sentido manter a categoria jurídica do empresário (o antigo comerciante) no campo das sociedades mercantis, não hesitamos em asseverar que o controlador é o empresário' (COMPARATO, Fábio K. O poder de controle na sociedade anônima, p. 104 e 106). Muito embora o art. 966 do CC defina como empresário quem exerce a atividade - ou seja, a própria sociedade-pessoa jurídica -, esse diploma legal não ignora a figura do controlador (art. 1.098), que é, porém, clara e minudentemente regulada pela Lei 6.404/1976 (... art. 116 e ss.), a qual impõe ao seu titular um feixe de deveres e responsabilidades próprios à sua função de comandante da atividade empresarial." (In: Comentários...Op. cit., p. 301).
}

${ }^{272}$ In: Comentários...Op. cit., p. 307-308. 
Discorda-se dessas duas interpretações.

Limitar a nomeação do gestor judicial à hipótese de afastamento do empresário individual significaria admitir que, na recuperação judicial da sociedade empresária, não há mecanismo para separar a figura da empresa da dos sócios, mesmo quando estes não estiverem contribuindo para a consecução da função social daquela. Tal interpretação é incorreta porque se apresenta desconforme aos fins sociais a que a lei se destina (Lei de Introdução, art. $5^{\circ}$ ).

Ora, em sendo a empresa economicamente viável, é preciso afastar dela os agentes (sócios e/ou administradores) que estejam agindo em desfavor da recuperação ${ }^{273}$. Afastar os administradores faltosos, substituindo-os por outros, mas manter sócios irresponsáveis, indiligentes ou ímprobos (que na maioria das vezes consentiram com as faltas cometidas pelos administradores, quando não as determina) é receita para o fracasso da recuperação.

Por outro lado, também não parece possível que o gestor judicial simplesmente "substitua" o sócio controlador, exercendo as suas funções de dentro da Assembleia-Geral de sócios.

O vínculo que garante o voto ao sócio não é o mesmo que outorga ao gestor poderes para administrar as atividades da sociedade. Enquanto os direitos políticos do sócio decorrem da propriedade, do status de sócio, o gestor assume a administração das atividades da sociedade por delegação extraordinária da lei e do juiz, pela circunstância de a empresa estar em recuperação judicial.

Disso resulta que o gestor judicial não será parte do contrato plurilateral de sociedade, como também não adquirirá nem o domínio nem o uso do feixe de direitos que decorre da participação societária do controlador. Sua relação com os demais sócios será inegavelmente distinta da que havia entre eles e o sócio controlador, sendo difícil imaginar que o gestor pudesse atuar na mesma posição de quem controlava a sociedade, tal como se ocorresse uma cessão de posição contratual ou o usufruto das quotas ou ações.

${ }^{273}$ Desde que tenham eles praticado alguma das condutas taxativamente previstas no art. 64 da LRF. 
Se a atuação do gestor judicial a partir de da estrutura societária se justificasse em razão dos interesses e prerrogativas dos sócios não-controladores, então, por lógica, ele também deveria respeitar os direitos estabelecidos no contrato/estatuto social ou em acordos de acionistas/quotista que outorgassem aos sócios não-controladores a condição de interferir na administração das atividades da sociedade, como, por exemplo, mediante o exercício de um poder de veto.

Não há como conceber, contudo, que a atuação do gestor possa ser limitada pelos acordos particulares dos sócios, como limitada seria se essa atuação se desse de dentro da Assembleia-Geral. Em inúmeros casos, tal limitação inviabilizaria o trabalho do gestor, tornando inócuo o afastamento do devedor.

O espírito da nova lei foi conferir à empresa condições para recuperar-se, como ao atribuir a sua administração a pessoa capaz de promover-lhe a função social e, ao mesmo tempo, dar cumprimento ao plano de recuperação, respeitando os interesses dos credores. Entendesse o legislador que, para esse mister, bastaria o afastamento do sócio controlador, não teria previsto a figura do gestor judicial, mas simplesmente atribuído aos sócios não-controladores (e não-faltosos) a administração da sociedade.

Em parte, a nomeação do gestor serve para suprir a ineficiência (ainda que não culposa) dos demais sócios em prevenir ou tornar ineficazes os atos do controlador que implicaram mau uso da sociedade. Deve-se recordar, a esse respeito, que os sócios nãocontroladores contam com diversos mecanismos para impedir esse mau uso da sociedade, como a ação para invalidar as deliberações tomadas com abuso de poder ou em conflito de interesses, a ação de responsabilidade dos controladores pelos atos danosos à sociedade e, ainda, no tocante à sociedade limitada, a ação para excluir o sócio que põe em risco a continuidade da empresa (Código Civil, art. 1.030).

Além disso, se o foco dos arts. 64 e 65 da LRF estivesse na pessoa do controlador, a alienação do controle a um terceiro ou a outro sócio (que não tenham praticado nenhuma das condutas previstas no art. 64) deveria liberar a sociedade do gestor judicial. A lei, no entanto, não contempla tal possibilidade, até porque daria ensejo a um sem número de fraudes. 
Na verdade, o foco dos art. 64 e 65 da LRF está na sociedade, que exerce, em nome próprio, a atividade empresária, e que por isso adquire o status de empresário, nos termos do art. 966 do Código Civil, conforme afirma PRISCILA CORRÊA DA FONSECA ${ }^{274}$ :

"O conceito de empresário abrange, de um lado, o empresário pessoa física, titular de firma individual, e, de outro, a pessoa jurídica que desenvolve atividade economicamente organizada para produção e circulação de bens e de serviços. É esta, por isso, chamada de sociedade empresarial..."

E se a sociedade, por meio do seu órgão máximo (a Assembleia-Geral), atuou de forma ilegítima contra a recuperação judicial e incidiu em alguma das condutas descritas no art. 64 da LRF, seria justificável, para atender à função social da empresa, tolher da sociedade o direito de tomar suas próprias decisões enquanto estiver em processo de recuperação.

Essa situação é sabidamente extrema, mas extremas são também as causas que justificam o afastamento do devedor e a nomeação do gestor judicial. Essas medidas, contudo, podem ser necessárias, senão até indispensáveis, para garantir a estabilidade da sociedade, o que, por via indireta, também acaba atendendo aos interesses dos sócios nãocontroladores.

Assim, no processo de recuperação judicial, o gestor atuará mesmo como órgão autônomo, externo à estrutura societária e com funções semelhantes à Assembleia-Geral, à qual se sobrepõe. Consequentemente, não estará vinculado aos arranjos havidos entre os sócios internamente à estrutura societária, acerca da administração da empresa.

\subsubsection{Qualquer outra matéria de interesse dos credores}

A alínea “f” do inciso I do art. 35 contém disposição genérica, que confere à AGC competência para deliberar sobre qualquer outra matéria de interesse dos credores não especificada nas alíneas anteriores. Essa previsão é positiva, pois o legislador seria

\footnotetext{
${ }^{274}$ Código Civil Comentado. AZEVEDO, Álvaro Villaça (coord.). São Paulo: Atlas, 2009. v. 11, p. 89.
} 
mesmo incapaz de prever todas as situações surgidas no curso da recuperação que pudessem ser de interesse dos credores.

No entanto, é preciso ter algum cuidado na aplicação do dispositivo, pois não parece possível invocá-lo para aprovar deliberações que atinjam a esfera jurídica dos credores dissidentes: a interferência das deliberações da AGC na esfera individual dos credores deve sujeitar-se às hipóteses e aos limites expressamente especificados na lei, sob pena de gerar insegurança jurídica.

Além disso, nas matérias de competência do Comitê de Credores, não cabe deliberação da AGC. Até porque, na falta do Comitê, suas funções competem ao administrador judicial, ou, na incompatibilidade deste, ao juiz (LRF, art. 28).

\subsection{Na falência}

Na falência, compete à Assembleia-Geral de Credores deliberar sobre as seguintes matérias: (i) a constituição do Comitê de Credores, a escolha de seus membros e sua substituição; (ii) a adoção de outras modalidades de realização do ativo, na forma do art. 145 desta Lei; e (iii) qualquer outra matéria que possa afetar os interesses dos credores. (LRF, art. 35, II).

A alínea "a" do inciso II do art. 35, que conferia à AGC a competência para deliberar a "a substituição do administrador judicial e a indicação do substituto", foi objeto de veto presidencial. Como já explicado, entendeu-se que a nomeação, destituição e substituição do administrador judicial deveria ficar exclusivamente a cargo do juiz, conforme já estabelecia o art. 23 da LRF.

\subsubsection{Constituição do Comitê de Credores}

O Comitê de Credores não é órgão exclusivo da recuperação judicial, também podendo ser constituído na falência, mediante deliberação de qualquer das classes da AGC, observada a composição especial definida no art. 26 da $\operatorname{LRF}^{275}$.

\footnotetext{
${ }^{275}$ Art. 26. O Comitê de Credores será constituído por deliberação de qualquer das classes de credores na assembléia-geral e terá a seguinte composição: I - 1 (um) representante indicado pela classe de credores
} 
$\mathrm{Na}$ falência, compete ao Comitê (i) fiscalizar as atividades e examinar as contas do administrador judicial, (ii) zelar pelo bom andamento do processo e pelo cumprimento da lei, (iii) comunicar ao juiz, caso detecte violação dos direitos ou prejuízo aos interesses dos credores, (iv) apurar e emitir parecer sobre quaisquer reclamações dos interessados, (v) requerer ao juiz a convocação da Assembleia-Geral de Credores, e (vii) manifestar-se nas hipóteses previstas na lei ${ }^{276}$, como, p. ex., para autorizar o cumprimento dos contratos bilaterais (LERF, art. 117, caput) ${ }^{277}$ ou opinar sobre a forma de realização do ativo (LRF, art. $\left.145, \S 1^{\circ}\right)^{278}$.

Ainda a propósito do tema, remete-se aos comentários feitos no item 4.1.2 deste Capítulo.

\subsubsection{Realização alternativa dos ativos do devedor}

$\mathrm{O}$ art. 140 da LRF estabelece uma ordem de preferência quanto à forma de realização dos bens do devedor, que tem por inspiração os princípios da eficiência, da maximização dos ativos e da função social da empresa.

Determina que, em primeiro lugar, seja tentada a alienação de toda empresa ${ }^{279}$, com a venda de seus estabelecimentos em bloco. Não sendo possível, passa-se à alienação das suas filiais ou unidades produtivas isoladamente. Depois, à alienação em bloco dos bens que integram cada um dos estabelecimentos do devedor. Finalmente, em último caso, procede-se à venda dos bens individualmente considerados.

trabalhistas, com 2 (dois) suplentes; II - 1 (um) representante indicado pela classe de credores com direitos reais de garantia ou privilégios especiais, com 2 (dois) suplentes; III - 1 (um) representante indicado pela classe de credores quirografários e com privilégios gerais, com 2 (dois) suplentes.

${ }^{276}$ Outras hipóteses de manifestação do Comitê se acham descritas nos arts. $8^{\circ}, 12,19$ e 142 da LRF.

${ }^{277}$ Art. 117. Os contratos bilaterais não se resolvem pela falência e podem ser cumpridos pelo administrador judicial se o cumprimento reduzir ou evitar o aumento do passivo da massa falida ou for necessário à manutenção e preservação de seus ativos, mediante autorização do Comitê.

${ }^{278}$ Art. 145, $\S 3^{\circ}$. Não sendo aprovada pela assembléia-geral a proposta alternativa para a realização do ativo, caberá ao juiz decidir a forma que será adotada, levando em conta a manifestação do administrador judicial e do Comitê.

${ }^{279}$ A alienação da empresa terá por objeto o conjunto de determinados bens necessários à operação rentável da unidade de produção, que poderá compreender a transferência de contratos específicos $\left(\operatorname{art} .140, \S 3^{\circ}\right)$. 
Além disso, segundo o art. 142 da LRF, a alienação do ativo será feita mediante leilão (por lances orais), propostas fechadas ou pregão, conforme venha a ser determinado pelo juiz depois de ouvido o administrador judicial e respeitada a orientação do Comitê de Credores, se houver. São essas as modalidades ordinárias ${ }^{280}$ de realização do ativo.

Poderá a Assembleia-Geral de Credores, no entanto, deliberar forma alternativa de realização do ativo, aí residindo a sua principal competência no processo de falência ${ }^{281}$. Conforme o art. 145 da LRF, o juiz deverá homologar qualquer outra modalidade de realização do ativo aprovada pela AGC, ainda que preveja a constituição de sociedade de credores ou dos empregados do próprio devedor, com a participação, se necessária, dos atuais sócios ou de terceiros.

A propósito da constituição de sociedade de credores, vale mencionar que, no âmbito da recuperação judicial, a Câmara Especial de Falências e Recuperações Judiciais do Tribunal de Justiça de São Paulo já decidiu que o plano de recuperação prevendo a conversão do crédito dos debenturistas em ações da própria companhia devedora seria ineficaz em relação aos credores dissidentes, ante a norma constitucional que garante o direito à livre associação $\left(\mathrm{CF}\right.$, art. $5^{\circ}, \mathrm{XX}$ - "ninguém poderá ser compelido a associar-se ou a permanecer associado”):

"Um dos princípios fundamentais estabelecidos pela Constituição da República é o da liberdade de associação (art. $\left.5^{\circ}, \mathrm{XX}\right)$. É por essa razão que a Lei $\mathrm{n}^{\circ}$ 6.404, de 15.12.1976, confere ao titular da debênture a conversão de seu crédito em ações, desde que com isso concorde. Sem a concordância, haveria clara violação da liberdade aludida. Ora, o plano de recuperação judicial aprovado impôs a conversão do crédito dos debenturistas em ações da empresa em recuperação. Violou, assim, a liberdade fundamental assegurada pela Constituição da República. Transformou o credor, ainda que subordinado, em acionista da empresa, assumindo, com isso, a

\footnotetext{
280 “a doutrina denomina as modalidades de alienação do ativo expressamente previstas no art. 142 de 'ordinárias'; as diversas e quaisquer outras modalidades referidas, respectivamente, nos arts. 144 e 145 de 'extraordinárias'; e a venda antecipada aludida no art. 113 de 'sumária'."(Mario Sergio Milani. Lei de recuperação judicial... Op. cit., p. 547).

${ }^{281}$ Essa era a única função da AGC no regime do Decreto $\mathrm{n}^{\circ}$ 7.661/45 (arts. 122 e 123). No entanto, a Assembleia de Credores quase nunca era convocada porque a fase de liquidação era relegada para o final do processo falimentar, após o relatório do síndico. A esta altura, boa parte dos bens do devedor - especialmente aqueles empregados em processos produtivos - já estava deteriorada, defasada tecnologicamente, ou simplesmente desvalorizada, desestimulando qualquer outra forma de alienação que não a venda em leilão judicial. Já não havia, então, o mínimo interesse dos credores.
} 
responsabilidade pela recuperação. A medida é, evidentemente, violadora do ordenamento jurídico. A rigor, competia ao magistrado, apesar da aprovação do plano, indeferir a recuperação judicial e decretar a falência. Todavia, não se olvidando da finalidade inicialmente mencionada, melhor será dar nova oportunidade aos credores para que, em outra assembléia geral, alterem o plano, eliminando a violação apontada". ${ }^{282}$

Nesse mesmo sentido foi o parecer do Prof. PAUlo F. C. SALLES DE TOLEDO ${ }^{283}$ oferecido por ocasião do referido julgamento:

"A Constituição Federal, como bem lembrou o douto Promotor de Justiça oficiante, estabelece, no art. $5^{\circ}$, inciso XX, a garantia de que ninguém pode ser obrigado a associar-se ou a permanecer associado. Ora, o plano de recuperação que veio a ser aprovado contempla a $P$, exclusivamente, com a conversão de suas debêntures em ações. Para que esta solução fosse viável, contudo, seria preciso que a credora quisesse tornar-se acionista da devedora. Não pode ela ser compelida a assumir essa posição, por força expressa do dispositivo constitucional invocado. (...) Mas a discussão não precisa alçar ao nível constitucional para que se conclua pela impossibilidade de se impor a conversão aos debenturistas. Com efeito (...), a conversão das debêntures em ações atinge a substância do direito do crédito, alterando a sua natureza. $O$ debenturista deixaria de ser credor para passar a ser sócio (acionista) da antiga devedora. Evidentemente, isto não pode ocorrer contra sua vontade."

Mais recentemente, porém, a mesma Câmara do Tribunal de Justiça de São Paulo adotou posicionamento diverso, admitindo a validade do plano de recuperação aprovado por maioria que previa o pagamento dos credores com ações de companhia anônima a ser constituída:

“Ao julgador há de ser dado certo campo de atuação além dos limites literais da lei para que prevaleça o princípio da manutenção da empresa que revele possibilidade de superar a crise econômicofinanceira pela qual esteja passando. Quanto à previsão de pagamento em ações de sociedade anônima, evidente que não se confunde com constrangimento do agravante a associar-se, não só porque o agravante não precisa participar ativamente da nova sociedade, usando

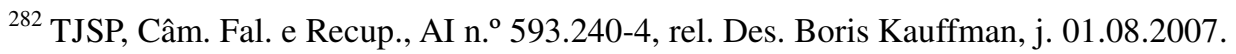

283 “Recuperação judicial - sociedades anônimas - debêntures - assembléia geral de credores - liberdade de associação - boa-fé objetiva - abuso de direito - cram down - par condicio creditorum." Revista de Direito Mercantil, Industrial, Econômico e Financeiro, São Paulo, n. 142, p. 280-281.
} 
as ações como valores mobiliários, como porque poderá livremente negociá-las." 284

Este último entendimento parece mais acertado, pois realmente não se vislumbra, no caso, violação do direito de livre associação: o credor não será compelido a tornar-se sócio, podendo, no extremo, recusar as ações ou quotas dadas em pagamento. $\mathrm{Na}$ prática, bastará alienar a participação recebida a terceiro ou exercer o recesso.

A liberdade de associação e o direito ao recebimento do crédito são coisas que não se confundem. $\mathrm{O}$ credor tem, sim, o direito de recusar a propriedade de quotas ou ações sociais, mas não tem, por conta disso, a prerrogativa de exigir que o seu crédito seja pago por meio diverso daquele aprovado pela $\mathrm{AGC}$, quando esta tenha deliberado a constituição de sociedade de credores.

A questão guarda alguma semelhança com o direito de recesso da sociedade anônima, que confere ao acionista o direito de se desligar da companhia mediante o reembolso do valor das suas ações, mas somente nas hipóteses taxativamente previstas ${ }^{285}$ nos arts. 137, 221, 236, 256 e 264 da Lei $n^{\text {o }} 6.404 / 76^{286}$. Ora, ninguém cogita de inconstitucionalidade da Lei das S.A., sob o argumento de que, ao limitar o recesso apenas a algumas hipóteses, estaria obrigando o acionista a manter-se associado.

Isso porque a Lei das S.A. não obriga ninguém a se manter sócio, mas simplesmente restringe as hipóteses de reembolso. Assim, mesmo fora das hipóteses de recesso, o acionista poderá se desvincular da sociedade, seja mediante a cessão das suas ações a terceiro (gratuita ou onerosamente), seja pela renúncia da sua participação, com a "devolução" das ações à companhia.

\footnotetext{
${ }^{284}$ TJSP, Câm. Fal. e Recup., AI n. ${ }^{\circ}$ 657.733-4/6-00, Rel. Des. Lino Machado, j. 27.10.2009.

${ }^{285}$ Cf. Alfredo Sérgio Lazzareschi Neto: "O recesso somente pode ser exercido nos casos previstos na lei: 'Nas sociedades anônimas, o direito de retirada do acionista é restrito às hipóteses do art. 137 da Lei $\mathrm{n}^{\circ}$ 6.404/76' (TJSP, $1^{\circ}$ Grupo de Câmaras Cíveis, AR 247.278-1, rel. Des. Vasconcellos Pereira, ação improcedente, v.u., j. 5.11.1997)" (Lei das Sociedades por Ações anotada... Op. cit., p. 378).

${ }^{286}$ Cf. Luis EduARdo BulhõES PedReira, os fatos que autorizam o direito de retirada podem ser classificados em três grupos: "I - modificações nos direitos de participação dos acionistas (...); II - outras modificações essenciais no contrato de companhia (...); aquisição de controle de sociedade empresária que constitua investimento relevante ou com pagamento de prêmio superior a 50\% do valor das ações" (In: LAMY FILHO, Alfredo; e BULHÕES PEDREIRA, José Luiz (Coords.). Direito das Companhias. Rio de Janeiro: Forense, 2009, v. 1, p. 341-342).
} 
Logo, o direito à liberdade de associação não poderá ser invocado como óbice à constituição de sociedade de credores, tanto na recuperação judicial quanto na falência, quando tal medida tenha sido legitimamente aprovada pela Assembleia-Geral de Credores, observados os quóruns exigidos em lei.

Em não sendo aprovada pela AGC a proposta alternativa para a realização do ativo, caberá ao juiz decidir a forma que será adotada, levando em conta a manifestação do administrador judicial e do Comitê (LRF, art. 145, § $3^{\circ}$ ). Ou seja, se o administrador judicial e o Comitê entenderem conveniente ao interesse dos credores a adoção de forma alternativa de realização do ativo, poderão requerê-la diretamente ao juiz, a despeito da rejeição da proposta pela AGC.

\subsubsection{Qualquer outra matéria de interesses dos credores}

Assim como se passa na recuperação judicial, reserva-se à AGC, na falência, competência residual para deliberar sobre quaisquer outras matérias de interesse dos credores (mas desde que não atinja a esfera jurídica dos credores dissidentes, conforme defendido no item 4.1.5 deste Capítulo).

\section{Convocação}

\subsection{Competência para a convocação}

No regime da Lei $n^{\circ} 11.101 / 2005$, a competência para a convocação da Assembleia-Geral de Credores é privativa ${ }^{287}$ do juiz, que age por impulso oficial decorrente de certos eventos (como a objeção de credores ao plano de recuperação, o afastamento do devedor ou a decretação da falência), ou mediante requerimento do administrador judicial, do Comitê de Credores ou de titulares de $25 \%$ ou mais do valor dos

\footnotetext{
287 “A convocação da assembleia geral dos credores é ato privativo do juiz diretor do processo (art. 36). A ele incumbe aferir a oportunidade e conveniência dessa convocação" (ALFREDO Assis GonÇALVES NETO. In: CORRÊA-LIMA, Osmar Brina; e LIMA, Sérgio Mourão Correa (coord.). Comentários à nova Lei de Falência e Recuperação de Empresa. Rio de Janeiro: Forense, 2009, p. 212).
} 
créditos de determinada classe, aos quais a lei confere legitimidade para pleitear a convocação da Assembleia-Geral.

Em regra, o pedido de convocação formulado pelos legitimados passará por uma análise meramente formal (p. ex., se o percentual mínimo de créditos foi atingido, ou se a deliberação do Comitê respeitou o procedimento legal), não cabendo o juiz imiscuir-se nas razões de conveniência que o fundamentaram. Para ALFREDo ASSIS GonÇALVES $\mathrm{NETO}^{288}$, cuida-se de ato de natureza administrativa (não judicante) e vinculado.

Excepcionalmente, porém, caso verificada situação de flagrante abuso (como na hipótese de seguidos pedidos de credor vencido para deliberar sobre o mesmo tema), parece justificado que o juiz denegue a convocação da AGC.

\subsection{Formalidades da convocação}

A Assembleia-Geral de Credores será convocada pelo juiz por edital publicado $^{289}$ no órgão oficial $e$ em jornais de grande circulação nas localidades da sede e filiais da empresa devedora ${ }^{290}$, com antecedência mínima de quinze dias (LRE, art. 36, caput).

\footnotetext{
288 "Tratando-se de competência concorrente, o comitê ou os credores com o percentual legal, se deles for a iniciativa, deveriam ser legitimados para promover a convocação. Como a lei concentrou esse poder na esfera de competência do juiz, tem-se, nesses casos, um ato de natureza administrativa (e não judicante) vinculado, que o juiz não pode deixar de praticar" (In: Comentários... Op. cit., p. 213).

289 "Saliente-se que o comando específico do art. 36 (“A assembléia-geral de credores será convocada pelo juiz por edital publicado no órgão oficial e em jornais de grande circulação nas localidades da sede e filiais") prevalece sobre o comando genérico veiculado no art. 191 ("as publicações ordenadas serão feitas preferencialmente na imprensa oficial e, se o devedor ou a massa falida comportar, em jornal ou revista de circulação regional ou nacional, bem como em quaisquer outros periódicos que circulem em todo o país"). (MARIO SERGIO Milani. Lei de recuperação judicial... Op. cit., p. 174).

${ }^{290}$ Cuida-se de requisitos cumulativos, cujo desatendimento poderá ensejar a invalidade da assembleia: "1. O art. 36, caput, da Lei $\mathrm{n}^{\circ} 11.101 / 2005$, exige a publicação do edital de convocação da assembléia de credores, tanto no órgão oficial como no jornal de circulação no local da sede da empresa recuperanda e de suas filiais com antecedência mínima de quinze dias. 2. O não atendimento aos requisitos cumulativos expressamente estabelecidos na lei especial acarreta a nulidade da assembleia de credores que delibera sobre o plano de recuperação judicial e de todos os atos subsequentes do processo de recuperação judicial (TJPR, AI $n^{\circ}$ 327.929-0, rel. Des. Renato Naves Barcellos, j. 31.1.2007; cf. Cristiano Imhof. Lei de recuperação... Op. cit., p. 181-182).
} 
Esse prazo é de direito material ${ }^{291}$, devendo ser contado da forma prevista no art. 132, caput, do Código Civil, isto é, excluindo-se o dia do começo e computando-se o do vencimento (que poderá ser o da própria assembleia), podendo ter início em finais de semana ou feriado.

O edital de convocação deverá conter: (i) o local, data ${ }^{292}$ e hora da assembléia em primeira e em segunda convocação; (ii) a ordem do dia; e (iii) o local onde os credores poderão obter cópia do plano de recuperação judicial no caso de vir a ser submetido à deliberação da assembléia (LRF, art. 36, caput). Além disso, cópia do aviso de convocação da assembléia deverá ser afixada de forma ostensiva na sede e em todas as filiais do devedor (LRF, art. 36, § $1^{\circ}$ ).

Quanto ao local da AGC, à falta de previsão legal sobre o assunto, alguns doutrinadores têm afirmado que ela deverá ser realizada na sede do devedor ${ }^{293}$. Como, todavia, a sede estatutária ou contratual nem sempre coincidirá com o local do principal estabelecimento - critério eleito pela lei para decidir o foro competente (LRF, art. $\left.3^{\circ}\right)^{294}$ quer parecer que, salvo se circunstâncias excepcionais indicarem providência diversa, a assembleia deverá ser realizada na comarca onde se processa a falência ou recuperação, o que tende a facilitar o controle e fiscalização do conclave, bem como contribuir para a maior participação dos credores.

Na prática, é comum a realização da AGC em tribunais do júri, ginásios, auditórios municipais ou até mesmo estádios, ante a incapacidade das instalações do devedor para comportar todos os seus credores, máxime quando há a participação de grande número de empregados.

\footnotetext{
${ }^{291}$ Cf. ERASMo VAlladẽo FrançA (In: Comentários... Op. cit., p. 200).

292 "Não há impedimento, ademais, para que a assembléia se realize também em domingos e feriados - que poderá até facilitar o comparecimento do maior número de credores” (Idem, p. 200).

${ }^{293}$ Nesse sentido, afirma MARIA ODETE DUQUE BERTASI: “A lei não estabelece o local de realização da AGC; porém é razoável afirmar que ela se realize na localidade da sede do devedor" (In: MACHADO, Rubens Approbato (Coord.). Comentários à nova lei de falências e recuperação de empresas. 2 ed. São Paulo: Quartier Latin, 2007, p. 151. Também é essa a opinião de MARIO SERGIO MILANI, por analogia ao art. 124, $2^{\circ}$, da Lei das S.A. (Lei de recuperação judicial... Op. cit., 36).

${ }^{294}$ Art. $3^{\circ}$. É competente para homologar o plano de recuperação extrajudicial, deferir a recuperação judicial ou decretar a falência o juízo do local do principal estabelecimento do devedor ou da filial de empresa que tenha sede fora do Brasil.
} 
Caso não tenha havido quórum suficiente para a instalação da AGC em primeira convocação, será ela realizada na data designada na segunda convocação, pelo menos cinco dias depois (LEF, art. 36, I). A esse respeito, FÁBIo UlhoA CoELHo ressalta não ser admitida " a praxe largamente utilizada em outros eventos assembleares (como em condomínio edilício, associações e clubes etc.) de realizar-se a segunda convocação no mesmo dia da primeira, iniciando-a nos 30 minutos seguintes”. Deverá ser respeitado, portanto, esse interregno mínimo de cinco dias.

A publicação da ordem do dia e do local ${ }^{295}$ onde poderá ser obtido previamente cópia do plano de recuperação judicial (LRF, art. 36, II e III) serve para que os credores possam meditar sobre a conveniência de comparecer ou não ao conclave, bem como sobre a orientação do seu voto. Cuida-se de regra de boa-fé, que visa a evitar que os credores sejam pegos de surpresa, tendo de deliberar de forma açodada ${ }^{296}$.

Os tribunais têm dado interpretação extensiva ao comando do art. 36, III, da LRF, a fim de garantir seja dado conhecimento aos credores, com antecedência razoável, até mesmo das modificações do plano de recuperação:

“Agravo. Recuperação Judicial. Alteração substancial e profunda do plano de recuperação judicial proposta sem observância de publicidade com antecedência razoável para o comparecimento de todos os credores. Vulneração dos princípios da lealdade, confiança e boa-fé objetiva. Natureza contratual da recuperação judicial que exige, na fase pré-contratual, conduta proba, honesta e ética, sob pena de afronta à boa-fé objetiva do art. 421 do Código Civil. A liberdade de contratar deve ser exercida sob a luz da função social da recuperação judicial. Inteligência do art. 421 do Código Civil. Apelo provido para anular a Assembleia-Geral, ordenando-se convocação de outro conclave no qual, o plano, observe as regras do art. 53 da Lei ${ }^{\circ}$ $11.101 / 2005^{, 297}$.

\footnotetext{
${ }^{295}$ Vem se tornando comum a praxe de disponibilizar a íntegra do plano de recuperação em sítios da internet.

296 “A intenção do legislador é possibilitar aos credores previamente conhecer o conteúdo do plano de recuperação para orientarem seus votos, de maneira a não votar 'no escuro' e nem passar pela dificuldade de ter que analisar o plano durante a recuperação da assembleia, de forma açodada" (RONALDO ALVES DE ANDRADE. In: DE LUCCA, Newton; e SIMÃO FILHO, Adalberto. Comentários à Nova Lei de Recuperação de Empresas e Falências. São Paulo: Quartier Latin, 2005, p. 183).
}

${ }^{297}$ TJSP, Câm. Fal. e Recup., AI nº 0493696-79.2010.8.26.0000, j. 18.10.2011. 


\subsection{Responsabilidade pelas despesas}

As despesas com a convocação e a realização da Assembleia-Geral correm por conta do devedor ou da massa falida ${ }^{298}$, salvo se convocada em virtude de requerimento do Comitê de Credores ou por credores que representem $25 \%$ ou mais do valor total dos créditos de uma determinada classe ${ }^{299}$. Na primeira hipótese, isto é, se a AGC for convocada a pedido de determinados credores (que representem $25 \%$ do valor total dos créditos de determinada classe), as despesas deverão ser suportadas apenas por eles. Por outro lado, se a convocação se der a requerimento do Comitê, todos os credores haverão de arcar com as despesas, proporcionalmente ao valor do seu crédito ${ }^{300}$.

\subsection{Hipóteses de convocação}

A Assembleia-Geral de Credores será convocada pelo juiz nas seguintes hipóteses:

(i) caso algum credor tenha formulado objeção ao plano de recuperação, a fim de que se delibere sobre a sua aprovação, rejeição ou modificação (LRF, art. 56, caput);

(ii) a pedido do administrador judicial, nos casos previstos em lei ou quando entender necessária sua ouvida para a tomada de decisões (LRF, art. 22, I, “g”);

(iii) a pedido do Comitê de Credores (LRF, art. 27, I, “e”);

(iv) a pedido dos credores representantes de $25 \%$ do valor dos créditos de determinada classe (LRF, art. 36, $\S 2^{\circ}$ );

\footnotetext{
${ }^{298}$ Quando a convocação se der (i) em razão de objeção ao plano de recuperação, a fim de que se delibere sobre a sua aprovação, rejeição ou modificação (LRF, art. 56), (ii) a pedido do administrador judicial, nos casos em que reputar necessária ouvi-la para a tomada de decisões (LRF, art. 22, I, "g"), (iii) em virtude do afastamento do devedor, para que seja eleito um gestor judicial (LRF, art. 65); (iv) por ocasião da decretação da falência, se o juiz entender conveniente a convocação para a constituição de Comitê de Credores (LRF, art. 99, XII).

${ }^{299}$ Para JAIRO SADDI, “essa previsão é sensata e acertada, uma vez que desestimula a convocação a expensas do devedor por motivo pouco relevante". In: PAIVA, Luiz Fernando Valente de (coord.). Direito falimentar na nova lei de falências e recuperação de empresas. São Paulo: Quartier Latin, 2005, p. 206.

${ }^{300}$ Ainda que o representante de alguma das classes tenha votado contra a convocação, eis que as decisões do Comitê são tomadas por maioria (LRF, art. $27, \S 1^{\circ}$ ).
} 
(v) quando do afastamento do devedor, nas hipóteses previstas no art. 64, para a escolha ou substituição do gestor judicial (LRF, art. 65 , caput e $\S 2^{\circ}$ ); e

(vi) quando da decretação da falência, se o juiz entender conveniente a convocação para a constituição de Comitê de Credores (LRF, art. 99, XII).

\subsubsection{Convocação em razão da objeção dos credores ao plano}

Dispõe o art. 55, caput, da LRF que "qualquer credor poderá manifestar ao juiz sua objeção ao plano de recuperação judicial”, a qual ensejará, nos termos do art. 56, caput, da mesma lei, a convocação da Assembleia-Geral de Credores "para deliberar sobre o plano de recuperação”.

Justamente por isso, ou seja, porque determina a realização da AGC para o exercício da sua mais relevante atribuição, a objeção referida no art. 55 demanda especial atenção deste trabalho, sobretudo em razão da ausência de consenso na doutrina e na jurisprudência acerca dos contornos desse instituto, ainda pouco estudado.

\subsubsection{Natureza jurídica da objeção}

Sem a pretensão de solucionar esta questão, vale ressaltar a dificuldade de precisar-se a natureza jurídica da objeção prevista no art. 55, caput, da LRF. Indaga-se se ela constituiria $(i)$ um ato destinado a evitar a que se configure a aceitação do credor, pelo silêncio $^{301}$, quanto ao plano de recuperação, ou se seria (ii) uma faculdade processual, que se não exercida acarreta um ônus também processual.

Tende-se a concluir pela segunda alternativa, à vista da distinção entre o silêncio (enquanto formador de um negócio jurídico) e a inércia processual (que importa em ônus processual).

\footnotetext{
${ }^{301}$ Ressalte-se que a aceitação pelo silêncio é coisa diversa de aceitação tácita. A aceitação tácita pressupõe a prática de determinado ato (um fazer) que permite deduzir determinada manifestação de vontade, o que é diferente da aceitação pelo silêncio, que envolve uma inação. No caso de não haver objeções, não haveria "aceitação tácita" pelos credores (que não praticaram ato algum), ao contrário do que afirma inadvertidamente a doutrina; quando muito, poderia haver aceitação pelo silêncio.
} 
Segundo leciona RENAN LOTUFO ${ }^{302}$, a eficácia do silêncio no negócio jurídico é positiva, enquanto que a eficácia da inércia processual é preclusiva, resultando da inobservância de um ônus de iniciativa especificado em lei, como na situação de revelia no processo, que pode até ser considerada como confissão: “nessa hipótese temos que a lei fixa uma situação de ônus que, se não for satisfeita, pode gerar uma situação incômoda para a parte no processo. É totalmente diversa da situação de quem recebe proposta e silencia, quando tem o dever de se manifestar sobre a aceitação ou não”.

Quando o credor deixa de oferecer objeção no prazo legal, sujeita-se aos ônus da sua inércia, entre os quais se acha a própria concessão da recuperação, caso nenhum outro credor tenha impugnado plano. O "silêncio" do credor não significa, necessariamente, que ele concorde com o plano de recuperação. Fosse aceitação pelo silêncio, não faria sentido que esse mesmo credor pudesse (como de fato pode) votar pela rejeição do plano na AGC. É perfeitamente possível, p. ex., que o credor não tenha oferecido objeção por puro desinteresse no processo de recuperação, o que não significa que estivesse de acordo com a redução do seu crédito em $50 \%$.

Também não se há falar em aceitação ou aprovação tácita, como afirmam alguns doutrinadores ${ }^{303}$. Pois a aceitação tácita, diferentemente da aceitação pelo silêncio, não decorre da inação, mas pressupõe a prática de um ato (um fazer) a partir do qual se pode deduzir a manifestação de vontade. Na hipótese de ausência de objeções, não haveria "aceitação tácita" pelos credores (que não praticaram ato algum); quando muito, poderia haver aceitação pelo silêncio, embora disso também não se cuide, conforme exposto acima.

Admite-se, contudo, que a questão merece maior aprofundamento, que excede os limites do presente trabalho.

\footnotetext{
302 Código Civil Comentado. São Paulo: Saraiva, 2003, v. 1, p. 301.

${ }^{303}$ Nesse sentido, ADALBERTO SIMÃo FILHO, ao referir-se ao art. 55 da LRF, menciona a existência de um “sistema de aprovação tácita" ("Interesses transindividuais dos credores...”... Op. cit., p. 49). MARLON TOMAZETTE também afirma que "caso os credores concordem com o plano apresentado, eles devem aproválo, a princípio de forma tácita, isto é, sem se manifestar” (Curso de Direito Empresarial... Op. cit., p. 198).
} 


\subsubsection{Forma da objeção: é necessário fundamentar?}

Se o credor quiser manifestar ao juiz sua objeção ao plano de recuperação, nos termos do art. 55 da LRF, deverá fazê-lo por escrito, mediante petição.

A doutrina debate, contudo, sobre a necessidade de a objeção ser ou não fundamentada, existindo certo consenso entre os autores no sentido de exigir dos credores a explicitação das causas da sua discordância quanto ao plano de recuperação.

JORGE LOBO ${ }^{304}$ afirma, sem dar maiores explicações, que a objeção deverá ser feita por "petição fundamentada, em que deverá deduzir as razões de fato e de direito com que se contrapõe ao plano”305, acrescentando WALDO FAZZIO JÚNIOR ${ }^{306}$ que “os credores que impugnarem o plano apresentado têm o ônus de demonstrar que sua materialização lhes causaria mais perdas que a outros credores, ou mesmo a outras categorias de credores".

Jỗo BosCO CASCARDo GOUVÊA ${ }^{307}$ também rejeita a possibilidade de uma objeção "estéril, desarrazoada, vazia de conteúdo", que encerraria uma contradição. Nas suas palavras, "não se contesta apenas por contestar”.

Para MÁRCIO GUIMARÃES ${ }^{308}$, a ausência de fundamentação da objeção poderia caracterizar abuso por parte do credor:

\footnotetext{
${ }^{304}$ In: TOLEDO, Paulo Campos Salles de; e ABRÃO, Carlos Henrique (coords.). Comentários à Lei de Recuperação de Empresas e Falência. 5 ed. São Paulo: Saraiva, 2012, p. 212.

305 O Prof. JORGE LOBO destaca que a lei concursal argentina (Ley 24.522/1995, art. 50) exige expressamente que a objeção dos credores seja fundamentada, restringindo as causas de impugnação do plano de recuperação (Idem, p. 212). Convém esclarecer, porém, que essa objeção da lei argentina em nada se assemelha com aquela prevista no art. 55 da lei brasileira. O procedimento de aprovação do "concurso preventivo" argentino é muito diferente daquele em que se aprova a nossa recuperação judicial. Na Argentina, o devedor possui determinado prazo para colher dos credores que representem determinado quórum a manifestação da sua concordância com o acordo proposto. A obtenção dessa aprovação resultará na existência do acordo, que será declarada pelo juiz, a fim de que se torne pública. Só então, depois de alcançado o acordo, é que os credores poderão impugná-lo (inclusive por conta da inobservância do quórum necessário à sua aprovação). Por fim, à vista da impugnação dos credores, o juiz decidirá sobre a homologação do acordo (cf. JUNYENT BAS, Francisco; e SANDOVAL, Carlos A. Molina. Ley de Concursos y Quiebras Comentada. 2 ed. Buenos Aires: AbeledoPerrot, 2009, p. 367-372).

${ }^{306}$ Lei de Falência e Recuperação de Empresas. 4 ed. São Paulo: Atlas, 2008, p. 158.

${ }^{307}$ Recuperação e Falência. Rio de Janeiro: Forense, 2009, p. 71.
} 
“o oferecimento de objeção pelos credores não pode se dar de forma sucinta, apenas em uma petição indicativa da negativa do plano, sem qualquer fundamentação, sob pena de violação do novo sistema legal, devendo o credor, prima facie, exercer seu direito de forma responsável, sem a caracterização de abuso. Assim, defendemos que a objeção somente poderá ser apreciada quando oposta de forma fundamentada."

Em abono desse entendimento, poder-se-ia ainda ressaltar os custos que envolvem a convocação da Assembleia-Geral, como justificativa para exigir-se dos credores a exposição dos motivos pelos quais se opõem ao plano apresentado.

Entre os autores consultados, LuIZ FERNANDo VALENTE DE PAIVA ${ }^{309}$ é o único que, manifestando sobre o tema, não reconhece peremptoriamente a obrigatoriedade da exposição dos motivos da objeção. Ainda assim, diz ser "conveniente" a fundamentação, justamente para não se caracterizar o abuso de direito.

Em que pese a relevância das manifestações e de seus autores, parece haver razões que conduzem à conclusão diversa daquela até aqui exposta, as quais permitem reconhecer que a objeção dispensa fundamentação.

A Lei $n^{\circ} 11.101 / 05$, ao tratar da objeção, não menciona a necessidade de fundamentação, diferentemente do que faz com relação a outros requerimentos, p. ex., de destituição do administrador judicial (LRF, art. 31) ${ }^{310}$, restituição de bens e valores (LRF, art. 87) $)^{311}$ ou adoção de forma alternativa de alienação de bens e valores (LRF, art. 144) $)^{312}$, para os quais exige expressamente a fundamentação. Assim, pela aplicação do adágio ubi lex voluit dixit, ubi noluit tacuit ("onde a lei quis, determinou; onde não quis, silenciou”), conclui-se que a objeção do art. 55 não exigiria fundamentação.

${ }^{308}$ In: CORRÊA-LIMA, Osmar Brina; e LIMA, Sérgio Mourão Correa (coord.). Comentários à nova Lei de Falência e Recuperação de Empresa. Rio de Janeiro: Forense, 2009, p. 390.

309 “Apresentação do plano de recuperação pelo devedor e a atuação dos credores”. Revista do Advogado, São Paulo, n. 83, set. 2005, p. 78.

${ }^{310}$ Art. 31 . O juiz, de ofício ou a requerimento fundamentado de qualquer interessado, poderá determinar a destituição do administrador judicial ou de quaisquer dos membros do Comitê de Credores quando verificar desobediência aos preceitos desta Lei, descumprimento de deveres, omissão, negligência ou prática de ato lesivo às atividades do devedor ou a terceiros.

${ }^{311}$ Art. 87. O pedido de restituição deverá ser fundamentado e descreverá a coisa reclamada.

${ }^{312}$ Art. 144. Havendo motivos justificados, o juiz poderá autorizar, mediante requerimento fundamentado do administrador judicial ou do Comitê, modalidades de alienação judicial diversas das previstas no art. 142. 
Nenhum autor parece cogitar da necessidade - também omitida pela lei - de o credor fundamentar o voto proferido em assembleia. ERASMO VALLADÃO FRANÇA ${ }^{313}$, talvez o único a se manifestar sobre esse tema, é categórico ao reconhecer que "as deliberações da assembléia ... não precisam ser motivadas, sendo tomadas de acordo com critérios de conveniência ou oportunidade”. Aliás, outra não tem sido a praxe nas assembleias: salvo nos casos em que alguém, sponte sua, queira declarar as razões do seu voto (p. ex., para rechaçar a suspeita de possível conflito de interesses ou de abuso), em geral os credores declaram laconicamente se são "a favor" ou "contra" o plano, nada mais lhes sendo exigido.

Ora, se para exercer o direito de voto em assembleia - que poderá culminar na falência da empresa no caso de rejeição do plano (LRF, art. $55, \S 4^{\circ}$ ) - não se exige do credor fundamentação alguma, por que se haveria de exigi-la para o mero exercício da objeção, cuja pior consequência para o devedor será a convocação da assembleia de credores? Salvo melhor juízo, a resposta a essa indagação é dada por outro conhecido adágio: in eo quod plus est semper inest et minus (“àquele a quem se permite o mais, não se deve negar o menos").

Mesmo que a objeção corresponda à manifestação de recusa a um negócio, não se haveria de exigir fundamentação, pois ninguém é obrigado a declarar por que não quer contratar, da mesma forma que a causa do contrato, entendida como "o motivo que leva o sujeito a integrar-se no contexto da relação contratual", também não precisa ser expressa. Aliás, a causa nessa acepção não é elemento de sua existência ${ }^{314}$.

Segundo a doutrina ${ }^{315}$ e a jurisprudência ${ }^{316}$, uma vez manifestada objeção por algum credor, só cabe ao juiz convocar a Assembleia-Geral, não se lhe permitindo apreciar

\footnotetext{
${ }^{313}$ In: SOUZA JÚNIOR, Francisco Satiro de; PITOMBO, Antônio Sérgio de Moraes (Coords.). Comentários à Lei de Recuperação de Empresas e Falência. São Paulo: Revista dos Tribunais, 2005, p. 194.

${ }^{314}$ Cf. DARCY BeSsOne. Do contrato: teoria geral. 4 ed. São Paulo: Saraiva, 1997, p. 102.

315 Para FÁBIO UlhoA COElho, "não cabe ao juiz apreciar o conteúdo da objeção ou decidi-la. A competência para tanto é de outro órgão da recuperação judicial: a Assembléia de Credores. Desse modo, ao receber qualquer objeção, o juiz deve limitar-se a convocar a Assembléia" (Comentários ...Op. cit., p. 228). No mesmo sentido se manifesta Silvânio Covas: "em relação à objeção, a nova lei limita a atuação do juiz à convocação da assembléia-geral, a qual deve apreciar o teor da manifestação dos credores e decidir sobre o plano de recuperação" (In: DE LUCCA, Newton; e SIMÃO FILHO, Adalberto. Comentários à Nova Lei de Recuperação de Empresas e Falências. São Paulo: Quartier Latin, 2005, p. 301).
} 
o mérito da objeção (ou seja, não é dado ao juiz analisar as razões de conveniência e oportunidade que ensejaram a objeção). Por que então exigir que os motivos da objeção sejam declinados se o juiz não poderá apreciá-los?

Nem se diga que tal exposição seria necessária para que a objeção fosse apreciada pela Assembleia-Geral de Credores. Conforme bem esclarecido por ADALBERTO SIMÃo FILHO ${ }^{317}$, caso convocada a assembleia para os fins do art. 56, ela não irá deliberar sobre as objeções oferecidas pelos credores, mas sobre a aprovação ou rejeição do plano de recuperação: "Trata-se da deliberação não sobre a questão que gerou a objeção por parte do credor, mas sim da aprovação do próprio plano de recuperação.”

Esse entendimento, embora controvertido ${ }^{318}$, não apenas é mais consentâneo com o disposto na lei - que prevê que, "havendo objeção de qualquer credor ..., o juiz convocará a assembléia-geral de credores para deliberar sobre o plano de recuperação" (LRF, art. 56, caput), como também está de acordo com a realidade das coisas, pois na prática só se costuma submeter à votação o plano como um todo, e não as objeções individuais.

Evidentemente, nas discussões que antecedem a votação, alguns credores insatisfeitos com o plano expõem as causas da sua oposição, na esperança de convencer os demais a rejeitá-lo ou exigir sua modificação. Porém, não haverá, em regra, deliberação individual sobre cada uma dessas objeções (o que, em alguns casos, dependendo do número de objeções, seria mesmo inviável).

\footnotetext{
${ }^{316}$ Entre outros, confira-se o Agravo de Instrumento no 482.851-4/4-00, julgado em 25.04.2007 pela Câmara Especial de Falências e Recuperações Judiciais do Tribunal de Justiça de São Paulo, Rel. Des. Boris Kauffmann: "Recuperação judicial. Plano de recuperação judicial. Objeção apresentada. Decisão do juiz rejeitando a objeção e deferindo a recuperação judicial, com alteração do plano apresentado pelo devedor. Inadmissibilidade. Atividade do juiz que está limitada a verificar a legalidade da forma proposta para a recuperação, a observância das exigências legais para a realização da assembléia geral de credores e a aprovação do plano e a inocorrência de abuso de direito de um credor ou um grupo de credores em detrimento dos demais. Decisão anulada para que seja convocada a assembléia geral de credores."

317 "Interesses transindividuais dos credores nas Assembléias-Gerais e sistemas de aprovação do plano de recuperação judicial”. In: DE LUCCA, Newton; DOMINGUES, Alessandra de Azevedo (coords.). Direito recuperacional. São Paulo: Quartier Latin, 2009, p. 50.

${ }^{318}$ Em sentido contrário, JORGE LOBO afirma: "se qualquer credor o impugnar, o juiz convocará a assembléia geral, para deliberar sobre: a) a objeção oposta pelo credor; e b) o plano de recuperação" (Lei de recuperação... Op. cit., p. 149).
} 
Ainda é preciso esclarecer o seguinte: a Assembleia-Geral de Credores não irá “julgar" o plano de recuperação ou as objeções a ele opostas, vale dizer, não decidirá se são procedentes ou improcedentes. Não há, portanto, um julgamento "da eficiência do plano" ou da "pertinência das objeções", mas deliberação ${ }^{319}$ sobre a celebração de um acordo, fundada em critérios de oportunidade e conveniência ${ }^{320}$.

Por fim, ressalte-se que a só circunstância de o credor não declarar os motivos da sua objeção não caracteriza abuso, que dependerá sempre de comprovação, não se podendo presumir a má-fé (ao contrário, o nosso sistema de direito privado presume a boafé).

O abuso, ademais, não se liga à causa do ato, dado que "o julgador não pode penetrar os motivos (também causais) ligados à utilidade individual, subjetiva ou intrínseca do ato”, matéria confiada apenas à discrição da parte. O que o juiz poderá verificar é se a finalidade visada pelo agente se conforma com a utilidade social do ato praticado (que lhe é extrínseca), a ordem pública e os bons costumes ${ }^{321}$.

Assim, mesmo uma objeção devida e comprovadamente fundamentada, que não deixe dúvida sobre a ineficiência do plano, poderá ser tida como abusiva se o fim pretendido pelo credor não for aquele previsto na lei (obstar a concessão da recuperação judicial), mas outro contrário à ordem pública, à boa-fé ou aos bons costumes (p. ex., fazer com que o devedor suporte as despesas decorrentes da realização da assembleia).

\subsubsection{Conteúdo da objeção}

O conteúdo da objeção prevista no art. 55 da LRF também tem sido objeto de divergências doutrinárias.

\footnotetext{
${ }^{319}$ O que não significa, porém, que os credores estejam dispensados de observar, no exercício do seu direito de voto, os fins sociais a que ele se destina, a boa-fé e o primado inserto no art. 47 da lei.

${ }^{320}$ Nesse sentido, ERASMO VALLADÃo FrANÇA afirma que "as deliberações da assembléia ... não precisam ser motivadas, sendo tomadas de acordo com critérios de conveniência ou oportunidade" (Comentários... Op. cit., p. 194 - destacou-se).

${ }^{321}$ Cf. DARCy BeSSONE. Do contrato... Op. cit., p. 105.
} 
RICARDO NEGRÃO ${ }^{322}$ afirma que, ao manifestar sua objeção, o credor poderá "livremente argüir ausência de requisitos formais, bem como matérias relativas ao conteúdo do plano, tais como inviabilidade técnica, sacrifício dos credores superior à liquidação na falência, inexatidão dos laudos e pareceres técnicos, existência de fraude ou crime praticado anterior ou simultaneamente ao pedido, etc."

NELSON RODRIGUES NETTO ${ }^{323}$ entende que, "por se tratar da primeira oportunidade de se manifestarem no processo, cabe aos credores também argüirem defeitos da petição inicial e que tenham passado despercebidos pelo juiz.”

WALDO FAZZIO JÚNIOR ${ }^{324}$ acrescenta ser “sempre possível que a fundamentação da inconformidade de alguns credores tenha raízes em eventual fraude no mecanismo de aprovação do plano, do que é exemplo a prestação de informações falsas ou a ocultação de dados essenciais relativos à empresa em recuperação”.

Até por conta do princípio constitucional da inafastabilidade da jurisdição, todas essas matérias poderão ser suscitadas pelos credores, sejam relativas aos pressupostos processuais do pedido e do plano de recuperação, à validade e eficácia jurídica das suas disposições, à existência de causa que obste a concessão do benefício, ou ainda à inviabilidade técnica ou econômica do plano.

Entretanto, nem todas essas matérias se inserem no exercício da objeção referida no art. 55 da LRF, nem terão por consequência a convocação da Assembleia-Geral de Credores, sendo essa talvez a principal causa das divergências - adiante expostas sobre os limites da atuação do juiz, em face das impugnações dos credores.

Cumpre, pois, distinguir as objeções que poderão ser formuladas pelos credores, bem como os seus respectivos efeitos.

\footnotetext{
${ }^{322}$ A eficiência do processo judicial na recuperação de empresa. São Paulo: Saraiva, 2010, p. 123-124.

${ }^{323}$ Comentários à Lei de Recuperação Judicial de Empresas e Falência. 4 ed. São Paulo: LTr, 2007, p. 106.

${ }^{324}$ Lei de Falência e Recuperação de Empresas. 4 ed. São Paulo: Atlas, 2008, p. 158.
} 


\subsection{Discordância do plano}

Assiste razão a ADALBERTO SiMÃo FILHO ${ }^{325}$ quando afirma que a objeção do art. 55 da LRF tem “intelecção de contrariedade e esta contraposição deve ser formulada pelo credor diretamente sobre o plano de recuperação judicial, seu conteúdo, consistência e fundamento, gerando assim, a necessidade de convocação de Assembléia-Geral”. Esse, aliás, é o sentido que decorre da interpretação literal do dispositivo, que concede aos credores prazo para manifestarem objeção "ao plano de recuperação", silenciando acerca de outras matérias passíveis de impugnação.

Necessário precisar, porém, que a objeção ao "plano de recuperação" prevista no art. 55 diz respeito à discordância do credor com os seus termos ou com a própria concessão da recuperação, mas tudo no âmbito da autonomia da vontade, no plano do querer. Ou seja, o credor se valerá da objeção, em princípio, não porque o plano é contrário à lei (contrariedade aqui referida em sentido amplo), mas porque não concorda com ele, pois não quer se submeter aos seus efeitos, preferindo a falência.

A objeção, nessa hipótese, poderá ter as mais variadas causas, como, p. ex., por entender o credor que o plano é tecnicamente inapto, que envolve riscos excessivos, que lhe trará prejuízos superiores aos que suportaria na falência, ou que o devedor e seus administradores não merecem confiança.

Todos esses são motivos para o credor não querer a recuperação, sendo obrigatória a convocação da assembleia-geral quando algum dos credores, no exercício da autonomia da vontade, manifestar sua recusa ao plano.

\subsection{Nulidades processuais}

É evidente que os credores (e também o Ministério Público) poderão suscitar ao juiz a ausência das condições da ação e dos demais pressupostos de desenvolvimento válido do processo, como a irregularidade da petição inicial e da representação do devedor, ou ainda a intempestividade do plano apresentado.

325 "Interesses transindividuais dos credores nas Assembléias-Gerais" ... Op. cit., p. 49-50. 
Entretanto, todas essas matérias podem (e devem) ser conhecidas pelo juiz de ofício, não possuindo a assembleia-geral de credores poderes para apreciá-las, nem, muito menos, superá-las. Daí que não há razão para convocá-la, no caso de a objeção fundar-se apenas em nulidades.

Note-se ainda que a arguição dessas matérias não se sujeita ao prazo previsto no art. 55 da LRF, podendo ser feita a qualquer tempo, enquanto não passada em julgado a sentença concessiva da recuperação. Conforme o art. 245, parágrafo único, do Código de Processo Civil, a nulidade processual absoluta ${ }^{326}$ não se sujeita à preclusão.

\subsection{Causas impeditivas da recuperação}

Os credores também poderão alertar o juízo sobre as causas que obstam a concessão da recuperação, como o não cumprimento dos requisitos referidos nos incisos do art. 48 do $\mathrm{LRF}^{327}$.

Fundando-se a objeção do credor, p. ex., no fato de o devedor já ter obtido, há menos de 5 (cinco) anos, uma outra recuperação judicial (causa que, nos termos do art. 48, II, da LRF, impede a concessão de nova recuperação), de nada adiantará a convocação (e mesmo a eventual aprovação) da assembleia-geral, simplesmente porque, nessa hipótese, o devedor carece do direito subjetivo que postula. E a inexistência desse direito só poderá ser declarada pelo juiz, único investido da jurisdição.

\footnotetext{
${ }^{326}$ Cuidando-se, porém, de nulidade relativa, deverá o credor alegá-la na primeira oportunidade em que lhe couber falar nos autos. Para JORGE LOBO, a primeira oportunidade que o credor terá para falar nos autos se dará no prazo de 15 dias contado a partir da publicação do edital referido no art. 52, § $1^{\circ}$, da LRF, que dá ciência do ajuizamento da ação. Segundo o autor, nesse prazo o credor teria o direito de "contestar" o pedido inicial (Comentários... Op. cit., p. 147). Tal posição, contudo, não encontra apoio no restante da doutrina, que não aventa o cabimento de "contestação" no processo da recuperação judicial (até porque a LRF não prevê tal figura).

${ }^{327}$ Art. 48. Poderá requerer recuperação judicial o devedor que, no momento do pedido, exerça regularmente suas atividades há mais de 2 (dois) anos e que atenda aos seguintes requisitos, cumulativamente: I - não ser falido e, se o foi, estejam declaradas extintas, por sentença transitada em julgado, as responsabilidades daí decorrentes; II - não ter, há menos de 5 (cinco) anos, obtido concessão de recuperação judicial; III - não ter, há menos de 8 (oito) anos, obtido concessão de recuperação judicial com base no plano especial de que trata a Seção V deste Capítulo; e IV - não ter sido condenado ou não ter, como administrador ou sócio controlador, pessoa condenada por qualquer dos crimes previstos nesta Lei.
} 
Também nesse caso, a objeção do credor não estará sujeita ao prazo do art. 55 da LRF. Em primeiro grau, a existência de causa impeditiva da recuperação poderá ser alegada até a prolação da sentença, podendo ainda fundamentar agravo contra ela interposto, nos termos do art. 59, $\S 2^{\circ}$, da $\operatorname{LRF}^{328}$.

\subsection{Invalidade do plano de recuperação}

Questão complexa envolve a objeção fundada em eventual invalidade do plano de recuperação proposto pelo devedor. Evidentemente, essa matéria também poderá ser suscitada pelos credores, mas não é tão simples resolver se, uma vez alegada no prazo referido no art. 55 da LRF, a assembleia-geral de credores deverá ou não ser convocada.

O plano fulminado de nulidade (p. ex., por prever prazo superior a um ano para pagamento dos créditos derivados da relação do trabalho, em afronta ao art. 54 da LRF), mesmo que venha a ser aprovado pela AGC, não será homologado pelo juiz.

Porém, uma vez convocada a assembleia, poderá ela deliberar "a modificação do plano de recuperação judicial apresentado pelo devedor" (LRF, art. 35), podendo ocorrer de a modificação aprovada sanar a invalidade então existente. E caso aceita a modificação pelo devedor (LRF, art. $56, \S 3^{\circ}$ ), o resultado será um plano válido, passível de homologação pelo juiz.

Tal situação suscita várias indagações: $1^{a}$ ) tomando conhecimento da objeção de credor que se opõe ao plano em razão da sua nulidade, poderá o juiz convocar a assembleia-geral? $2^{a}$ ) poderia o devedor, à vista da impugnação de algum credor, emendar o plano oferecido, a fim de sanar a nulidade? $3^{\text {a }}$ ) caso a assembleia venha a ser convocada, resultando na aprovação de um plano válido, o fato de a proposta original ser inválida obstará a concessão da recuperação?

Contrariamente à possibilidade de convocação da assembleia no caso de nulidade da proposta do devedor, pode-se alegar o seguinte: se à falta de objeção o juiz está

\footnotetext{
${ }^{328}$ Art. 59, § $2^{\circ}$. Contra a decisão que conceder a recuperação judicial caberá agravo, que poderá ser interposto por qualquer credor e pelo Ministério Público.
} 
impedido de convocar a assembleia ${ }^{329}$, devendo decretar a falência em face da nulidade do plano, com mais razão não poderá convocá-la se houve objeção alertando para a ocorrência de nulidade.

A existência ou inexistência de objeção por parte do credor é irrelevante para o reconhecimento do vício, declarável de ofício pelo juiz. Ademais, podendo a nulidade ser arguida a qualquer tempo, mesmo depois de decorrido o prazo para obter o plano, não faria sentido que apenas a objeção oferecida no interregno fixado pelo art. 55 ensejasse a convocação da assembleia.

Cabe dizer, por fim, que a competência para decidir eventuais nulidades do plano de recuperação é do juiz, não da assembleia de credores, sendo injustificado convocá-la em razão de objeção que não lhe cabe apreciar, não devendo ser desprezados os custos decorrentes da realização da assembleia. Seria, no mínimo, temerária a convocação da AGC com base na mera expectativa de que alguma modificação, aprovada tanto pelos credores quanto pelo devedor, seja capaz de resolver a nulidade.

Nessa hipótese, em que pese o art. 53, caput, da LRF estabelecer que “o plano de recuperação será apresentado pelo devedor em juízo no prazo improrrogável de sessenta dias (...), sob pena de convolação em falência”, melhor seria conferir ao credor a possibilidade de emendar o plano para corrigir o vício, em atenção aos princípios da lei ${ }^{330}$.

\footnotetext{
${ }^{329}$ Nesse sentido, entendendo incabível a convocação da assembléia geral de credores, em face da ausência de objeção ao plano, já decidiu a Câmara Reservada à Falência e a Recuperação do Tribunal de Justiça de São Paulo: "Ocorre que a Lei $n^{\circ}$ 11.101/2005 é expressa no sentido de que, só haverá convocação de assembleia-geral de credores para deliberar sobre o plano recuperatório se houver objeção. Como não há dúvida de que não foi deduzida nenhuma objeção ao plano, a assembléia geral não poderia ter sido convocada e, muito menos, realizada, mercê do que, a deliberação dos cinco credores é ineficaz e não pode ser acolhida como objeção". (AI 990.10.005006-0, Rel. Pereira Calças, j. 06.04.2010).
}

Em sentido contrário, entendendo que, mesmo sem impugnação ao plano, o juiz poderá, de ofício ou a requerimento do MP, submeter a aprovação do plano à deliberação da AGC: "Não havendo manifestação de nenhum credor quanto ao plano apresentado, há possibilidade de, mesmo assim, o MP pugnar ou o próprio juízo da recuperação entender necessária a realização de assembléia geral de credores, designando dia para a sua realização." (MÁRCIO GUIMARÃES. In: CORRÊA-LIMA, Osmar Brina; e LIMA, Sérgio Mourão Correa (coord.). Comentários à nova Lei de Falência e Recuperação de Empresa. Rio de Janeiro: Forense, 2009, p. 392).

${ }^{330}$ Vale destacar novamente o princípio insculpido no art. 47 da LRF, bem como lembrar que o processo - e muito especialmente o processo de recuperação - não é um fim em si mesmo, mas instrumento de promoção da justiça distributiva. Assim, sendo possível a correção do vício existente no plano, sem que nenhum prejuízo resulte aos credores, não seria razoável impedir o devedor de promover a modificação. 
Diga-se, ademais, que tem sido frequente a alteração do plano pelo próprio devedor antes da realização da AGC, não obstante o silêncio da lei acerca dessa possibilidade ${ }^{331}$.

Mas caso a AGC venha a ser convocada a despeito da nulidade do plano e acabe aprovando um plano diferente, válido, restará superada a invalidade da proposta original, não se justificando a aplicação do art. 248 do Código de Processo Civil, segundo o qual, "anulado o ato, reputam-se de nenhum efeito todos os subseqüentes, que dele dependam”.

Esse entendimento se acha conforme os princípios informadores da lei concursal, sobretudo o princípio da preservação da empresa (LRF, art. 47). Apesar daquela invalidade inicial, tendo o ato alcançado a sua finalidade - qual seja, promover o acordo entre o devedor e a maioria dos credores quanto à recuperação -, poderá o juiz superar a irregularidade com fundamento na teoria da instrumentalidade do processo (ainda que aplicada em bases alargadas).

\subsection{Ineficácia do plano de recuperação}

Também poderá ocorrer de o plano de recuperação conter alguma disposição que, embora válida, atinja credores que não poderiam ser por ele afetados. É o caso - aliás, bastante comum - do plano que contempla os credores referidos no art. $49, \S \S 3^{\circ}$ e $4^{\circ}$, da $\mathrm{LRF}^{332}$, legalmente excluídos dos efeitos da recuperação.

\footnotetext{
331 Ao contrário do que ocorre, p. ex., na Argentina, cuja lei prevê que o devedor poderá apresentar modificações à proposta de acordo preventivo até a realização da audiência informativa, convocada para a hipótese de não se ter conseguido as aprovações necessárias à homologação do acordo (Ley 24.522/1995, art. 43, último parágrafo).

332 Art. $49 \ldots \S 3^{\circ}$. Tratando-se de credor titular da posição de proprietário fiduciário de bens móveis ou imóveis, de arrendador mercantil, de proprietário ou promitente vendedor de imóvel cujos respectivos contratos contenham cláusula de irrevogabilidade ou irretratabilidade, inclusive em incorporações imobiliárias, ou de proprietário em contrato de venda com reserva de domínio, seu crédito não se submeterá aos efeitos da recuperação judicial e prevalecerão os direitos de propriedade sobre a coisa e as condições contratuais, observada a legislação respectiva, não se permitindo, contudo, durante o prazo de suspensão a que se refere o $\S 4$ o do art. 6o desta Lei, a venda ou a retirada do estabelecimento do devedor dos bens de capital essenciais a sua atividade empresarial. $\S 4^{\circ}$. Não se sujeitará aos efeitos da recuperação judicial a importância a que se refere o inciso II do art. 86 desta Lei. (Art. 86, II - da importância entregue ao devedor, em moeda corrente nacional, decorrente de adiantamento a contrato de câmbio para exportação, na forma do art. 75, §§ 3o e 4o, da Lei no 4.728, de 14 de julho de 1965, desde que o prazo total da operação, inclusive eventuais prorrogações, não exceda o previsto nas normas específicas da autoridade competente).
} 
Nesse caso, estar-se-ia diante de disposição ineficaz, como ineficaz seria, em relação aos credores excluídos, a deliberação da assembleia que aprovasse um plano assim, conforme ensina ERASMO VALLADÃO FRANÇA ${ }^{333}$ :

\begin{abstract}
"De maneira geral, pode-se dizer que são ineficazes as deliberações que alteram, ou sejam suscetíveis de alterar direito especiais de credores ou direitos de terceiros antes que estes consintam. Imaginese a hipótese de ser aprovado um plano de recuperação judicial, por exemplo, que implique alteração da variação cambial de determinadas obrigações do devedor. Tal deliberação só produzirá efeitos se os credores das mesmas concordarem ( $\S 2^{\circ}$ do art. 50). Do contrário, a deliberação pode até ser válida, mas é ineficaz."
\end{abstract}

Não há nada na lei que impeça o devedor de incluir no plano créditos que, em princípio, não se sujeitam à recuperação. Ocorre, porém, que tal disposição só se tornará eficaz com a aceitação dos credores por ela afetados, conforme salienta MODESTO CARVAlHOSA $^{334}$ :

“...cumpre salientar que a Lei de Recuperação e Falências, ao mencionar que tais créditos não se submetem à recuperação judicial, não vedou a sua inclusão no plano apresentado pelo devedor. Assim, se houver a anuência desses credores, seus créditos poderão ser incluídos na recuperação."

Não se nega a esses credores, entretanto, o direito de ver declarada ${ }^{335}$ a inexistência da sua vinculação ao plano de recuperação (CPC, art. $\left.4^{\circ}, \mathrm{I}\right)^{336}$, caso este os tenha contemplado. Poderão requerer tal declaração ao próprio juízo da recuperação, bem como impugnar quaisquer decisões que, inadvertidamente, afirmem sua sujeição aos efeitos do plano.

\footnotetext{
${ }^{333}$ Comentários... Op. cit., p. 190.

${ }^{334}$ Referindo-se aos credores mencionados nos $\S \S 3^{\circ}$ e $4^{\circ}$ do art. 49 da LRF (In: CORRÊA-LIMA, Osmar Brina; e LIMA, Sérgio Mourão Correa (coord.). Comentários à nova Lei de Falência e Recuperação de Empresa. Rio de Janeiro: Forense, 2009, p. 281).

335 Conforme ERASMo VAlladẽo FrançA, "a tutela processual da ineficácia, esclareça-se, é meramente declaratória."

${ }^{336}$ Art. $4^{\circ}$. O interesse do autor pode limitar-se à declaração: I - da existência ou da inexistência de relação jurídica.
} 
Mas nada disso - é claro - tem a ver com a objeção de que trata o art. 55 da LRF: a arguição da ineficácia de disposições do plano não se sujeita ao prazo nele referido, nem tampouco enseja a convocação da assembleia-geral de credores.

\subsubsection{Prazo da objeção}

Os credores dispõem do prazo de 30 dias pra apresentar objeção ao plano, cujo termo inicial poderá se dar em dois momentos processuais distintos.

A fluência do prazo depende de duas publicações, quais sejam, a publicação do edital contendo o aviso de recebimento do plano de recuperação (LRF, art. 53, par. único) e a publicação do edital contendo a relação de credores definida pelo administrador judicial, nos termos do art. $7^{\circ}, \S 2^{\circ}$, da LRF.

O prazo começará a correr a partir da última publicação. Ou seja, caso já tenha sido publicado o aviso de recebimento do plano, o prazo começará a correr a partir da publicação da relação de credores prevista no art. $7^{\circ}, \S 2^{\circ}$, da LRF (art. 55, caput). Porém, se a publicação dessa relação ocorrer antes da publicação do aviso mencionado no art. 53, par. único, da LRF, o prazo começará a correr a partir da publicação do aviso de recebimento do plano (art. 55, par. único).

A complexidade é apenas aparente, sendo toda ela resolvida pelos claros ensinamentos de NELSON RodRigues NETTO ${ }^{337}$, que não carecem de nenhuma complementação:

"Primeiro: o art. 55, caput, diz que o prazo é de 30 dias a contar da publicação da relação de credores, conforme o art. $7^{\circ}, \S 2^{\circ}$. Bem, para se apurar o termo inicial deste prazo deve-se iniciar com a regra do art. 52, $\S 1^{\circ}$, III, que determina a publicação do edital de convocação de credores para que habilitem seus créditos no prazo de 15 dias, na forma do art. $7^{\circ}, \S 1^{\circ}$; decorrido esse prazo, deverá ser publicado o edital de confirmação de credores, no prazo de 45 dias, na forma do art. $7^{\circ}, \S 2^{\circ}$. É deste edital, portanto, que tem início o prazo de 30 dias

${ }^{337}$ Comentários... Op. cit., p. 106-107. 
para que os credores ofereçam objeções ao plano de recuperação, na forma do art. 55, caput.

Em segundo lugar, há outra contagem de prazo que se inicia com o deferimento da recuperação judicial (art. 52), seguindo-se o prazo de 60 dias para que o devedor apresente o plano de recuperação judicial (art. 53, caput) e, posteriormente, a ordem para a publicação de edital de aviso de recebimento do plano e de fixação do prazo para as respectivas objeções (art. 53, parágrafo único).

De tal sorte, o termo inicial para apresentações de objeção ao plano de recuperação deverá ser contado da data da última publicação entre o edital do art. $7^{\circ}, \S 2^{\circ}$, e o edital do art. 53, parágrafo único, conforme a redação do art. 55, parágrafo único. Não há dispensa de qualquer uma dessas publicações, e o prazo para oferecimento de objeções é de 30 dias."

\subsubsection{Credores legitimados a manifestar a objeção.}

Dispõe o art. 55 da LRF que "qualquer credor poderá manifestar ao juiz sua objeção ao plano de recuperação judicial”. Indaga-se, porém, se o referido dispositivo comporta interpretação literal, ou se há credores aos quais não é dado objetar o plano.

No primeiro sentido, poder-se-ia argumentar com o brocardo ubi lex non distinguit nec nos distinguere debemus (“onde a lei não distingue, não pode o intérprete distinguir"): como a lei não excetua credor algum, todos teriam o direito de manifestar ao juiz sua objeção ao plano, não podendo o intérprete fazer distinções. Entretanto, conforme ressalta CARLOS MAXIMILIANO ${ }^{338}$, seria erro generalizar a aplicação do adágio:

“ a regra não é tão absoluta como parece à primeira vista. O seu objetivo é excluir a interpretação estrita; porém esta está cabível e concludente quando houver outro motivo sério para reduzir o alcance dos termos empregados, quando a razão fundamental da norma se não estender a um caso especial; enfim, quando implicitamente ou em outras disposições sobre o mesmo assunto, insertas na mesma lei ou em lei diversa, prescreverem limites, ou exceções, ao preceito amplo. Avultaria a probabilidade de errar se o brocardo fora aplicado, sem a maior cautela, a um artigo isolado de lei excepcional"

${ }^{338}$ Hermenêutica e aplicação do direito. 11 ed. Rio de Janeiro: Forense, 1990. 
Assim, afigura-se correto restringir a faculdade da objeção tratada no art. 55, caput, da LRF àqueles credores que possuam interesse jurídico no seu exercício, pois se cuida de um ato processual, cuja eficácia se subordina - como ordinariamente ocorre com todos os atos processuais - à existência de interesse jurídico na sua prática, fundada no binômio necessidade/utilidade.

\section{(i) credores privados do direito de voto}

Mesmo os credores que são privados do direito de voto poderão ter interesse (direto ou indireto) na aprovação ou rejeição do plano de recuperação. Tanto é verdade que esses credores (privados do direito de voto) poderão ter interesse jurídico na deliberação sobre o plano que a lei própria lhes confere (em alguns casos, de forma expressa; noutros, de forma implícita) o direito de voz na assembleia.

Não há outra razão para conferir aos credores o direito de se manifestar na assembleia (a fim de debater o plano) senão o interesse jurídico que possuem na deliberação sobre aprovação ou rejeição do pedido de recuperação judicial. Logo, se possuírem interesse juridicamente tutelado, mesmo os credores sem direito de voto poderão, conforme o caso, ter legitimidade para oferecer objeção ao plano, que deverá ensejar a convocação da AGC:

“...verifica-se que, tendo o agravante formulado objeção ao plano, independentemente de não haver previsão que afete o valor e a forma de pagamento de seu crédito, tem ele o direito de exigir a convocação da assembleia-geral prevista no art. 56, que é obrigatória, desde que qualquer credor, mesmo que só um deles, maneje a objeção no trintídio legal. Não se olvide que, embora o plano não altere a quantia e a forma de pagamento do crédito de tal credor, ele poderá participar da assembléia e exercer seu direito de voz, ou seja, de se manifestar oralmente nas discussões sobre o plano recuperatório proposto pela devedora" ${ }^{, 339}$.

${ }^{339}$ TJSP, Câm. Fal. e Recup., AI nº n 990.10.142738-9, rel. Des. Pereira Calças, j. 6.7.2010. 
Ao excluir o direito de voto do credor, p.ex., no caso de o plano não alterar o valor ou as condições originais de pagamento do seu crédito (LRF, art. $45, \S 3^{\circ}$ ), "parte $o$ legislador do discutível pressuposto de que ao credor faltaria interesse na deliberação sobre o plano, 340 .

Conforme JAIRO SADDI ${ }^{341}$, a determinação constante do art. $45, \S 3^{\circ}$, da LRF é questionável, pois “mesmo não tendo seu crédito submetido diretamente ao processo de recuperação, o credor impedido de votar poderá ter o adimplemento das obrigações a ele relacionadas afetado na hipótese de um plano inócuo, que não traga a efetiva recuperação da empresa devedora."

No mesmo sentido lecionam FÁBio UlhoA COElho ${ }^{342}$ e Ronaldo Alves De ANDRADE $^{343}$, parecendo evidente que mesmo o credor referido no art. $45, \S 3^{\circ}$, da LRF poderá sair prejudicado com a aprovação do plano, o que o legitima a objetá-lo, nos termos do art. 55, caput, da LRF.

(ii) credores com vinculação societária ou de parentesco com o devedor, seu sócio ou controlador

Esses credores se sujeitarão, sem sombra de dúvida, aos efeitos da recuperação judicial, podendo suportar, direta ou indiretamente, as conseqüências decorrentes do plano de recuperação. Daí que, ao menos em princípio, têm legitimidade para manifestar a sua objeção.

\footnotetext{
${ }^{340}$ ERASMO VAlladão FranÇA. Comentários... Op. cit., p. 215.

${ }^{341}$ In: CORRÊA-LIMA, Osmar Brina; e LIMA, Sérgio Mourão Correa (coord.). Comentários à nova Lei de Falência e Recuperação de Empresa. Rio de Janeiro: Forense, 2009, p. 303.

342 "Essa exclusão da base de cálculo do quórum de deliberação do Plano justifica-se no pressuposto de que o credor não atingido pela proposta de reorganização da empresa não teria nenhum interesse no resultado da votação. Tal pressuposto é questionável porque, mesmo não sendo atingido diretamente pela proposta em votação, é claro que o credor pode ter o seu direito ameaçado na hipótese de aprovação de um plano inconsistente, que não leve à efetiva recuperação do devedor." (Comentários... Op. cit., p. 112).

343 “A presunção legal de que esse tipo de credor não tem interesse para votar o plano de recuperação judicial aparentemente é justificável, todavia, embora não estando o crédito sujeito aos efeitos direto da recuperação judicial, todos os credores sofrem indiretamente os influxos desse acordo de credores, uma vez que se o plano for mal elaborado e executado, a consequiência poderá ser a falência do devedor, que pode inclusive redundar em não pagamento do crédito. Assim, vislumbramos o interesse do credor quirografário ou privilegiado que não tendo afetadas as condições de seu crédito de longo prazo, poderia vir a sofrer prejuízo em razão do não cumprimento do plano de recuperação judicial, que poderia não ter sido aprovado se o referido credor tivesse votado. (In: DE LUCCA, Newton; e SIMÃO FILHO, Adalberto. Comentários à Nova Lei de Recuperação de Empresas e Falências. São Paulo: Quartier Latin, 2005, p. 199-200).
} 
Exceção talvez possa ser feita aos credores que integram a sociedade autora do pedido de recuperação judicial, que ficariam impedidos de impugnar o plano caso as suas condições tenham sido regularmente aprovadas em assembléia de sócios. Parece incidir aqui a regra do art. 1.071, $\S 5^{\circ}$, do Código Civil, segundo a qual as deliberações tomadas de conformidade com a lei e o contrato vinculam todos os sócios, ainda que ausentes ou dissidentes.

\section{(iii) credores retardatários}

Não há nenhum óbice a que os credores retardatários possam oferecer a objeção prevista no art. 55 da LRF, dado que, ao menos em princípio, se sujeitam aos efeitos da recuperação judicial. Têm, podendo, interesse e legitimidade para manifestar a sua objeção.

\section{(iv) credores excluídos dos efeitos da recuperação}

Situação diversa envolve os credores que, por expressa disposição legal, estão isentos dos efeitos da recuperação, como se passa com aqueles referidos nos arts. $49, \S \S 3^{\circ}$ e $4^{\text {o }}$, e 193 da LRF, ou seja, credores titulares da posição de: (i) proprietário fiduciário de bens móveis ou imóveis; (ii) arrendador mercantil; (iii) proprietário ou promitente vendedor de imóvel cujos respectivos contratos contenham cláusula de irrevogabilidade ou irretratabilidade, inclusive em incorporações imobiliárias; (iv) proprietário em contrato de venda com reserva de domínio; $(v)$ proprietário de créditos decorrentes de adiantamento a contrato de câmbio para exportação, o ACC; ou (vi) proprietário de créditos decorrentes de obrigações assumidas no âmbito das câmaras ou prestadoras de serviços de compensação e de liquidação financeira.

Ao menos à primeira vista, esses credores carecem de interesse (e, por conseguinte, de legitimidade) para impugnar o plano, já que, concedida a recuperação ou decretada a falência, sua situação não se modificará ${ }^{344}$. Assim, não teriam direito de

\footnotetext{
${ }^{344}$ E na hipótese de aceitarem voluntariamente se submeter aos efeitos do plano de recuperação (vide item 2.1 do Capítulo II), logicamente não terão interesse na objeção.
} 
manifestar ao juiz a objeção tratada no art. 55, caput, da LRF, conforme ensinam AdAlberto Simão FilHo $^{345}$ e JoÃo Bosco CASCARdo de GouvÊA ${ }^{346}$.

\subsubsection{Obrigatoriedade da convocação da AGC}

Se a objeção ao plano de recuperação for manifestada tempestivamente por

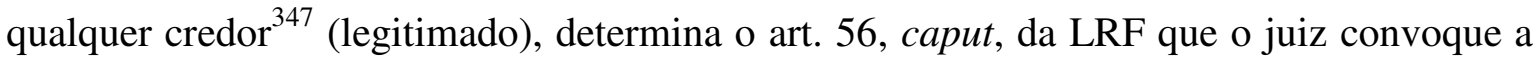
Assembleia-Geral de Credores. Em princípio, não se permite que o juiz, em face da objeção, deixe de convocar a AGC ou determine providência diversa ${ }^{348}$.

Não serão, porém, quaisquer objeções que ensejarão a convocação da assembleia, mas somente aquelas fundadas na contrariedade ao plano. Conforme se procurou demonstrar no item 5.4.1.3 acima, somente as objeções fundadas na discordância do credor com os termos do plano ensejarão a convocação da AGC. Não é o caso, portanto, das objeções fundadas em nulidades processuais, intempestividade ou irregularidades formais do plano, invalidade ou ineficácia do plano, ou na existência de causas impeditivas a concessão da recuperação. Nesses casos, as objeções serão julgadas pelo juiz, sem necessidade de convocação da AGC.

\footnotetext{
345 “Ainda, pode ser apresentada como objeção, alguma inconformidade por parte de credor que sequer é concorrente na recuperação judicial. (...) Nestes casos e assemelhados, entendemos pela desnecessidade da convocação da assembléia de credores por parte do juiz." ("Interesses transindividuais ..." Op. cit., p. 49-50).

346 “(...) o plano somente poderá sofrer objeções dos credores passíveis dos seus efeitos.” (Recuperação $e$ Falência. Op. cit., p. 157).

${ }^{347}$ Registre-se a crítica de MARIA CELESTE MORAIS GUIMARÃES à redação do art. 56 da LRF: “.... gostaríamos de registrar o nosso inconformismo com a expressão utilizada pelo legislador 'qualquer credor'. Não nos parece razoável outorgar a qualquer credor - por menor que seja o valor do seu crédito - legitimidade para oferecer objeção ao plano. Haveria de se ter fixado um percentual mínimo representativo do passivo do devedor para possibilitar a contestação do plano em face do interesse coletivo que permeia todo o processo de recuperação judicial. Um credor, por mais irrelevante que seja o seu crédito, causará transtorno, diga-se de passagem, de obrigar o juiz a convocar a Assembléia-Geral de Credores, quando a grande maioria está de acordo com o plano" (Recuperação judicial de empresas e falência. 2 ed. Belo Horizonte: Del Rey, 2007, p. 151).

348 "Ora, se há objeção, assinala o art. 56, caput, da Lei 11.101/05, cumpre ao juiz convocar a assembléia geral. Não lhe cabe ponderar se é ou não procedente, já que a deliberação a respeito é daquele órgão e não tem natureza jurisdicional" (TJSP, Câm. Fal. e Recup., AI ñ 994.09.328501-4, rel. Des. Araldo Telles, j. 4.5.2010).
} 
Além disso, se o credor desistir da objeção antes de convocada a AGC, não será necessária a sua realização, conforme já decidiu o Superior Tribunal de Justiça ${ }^{349}$ :

\begin{abstract}
“RECURSO ESPECIAL. PEDIDO DE RECUPERAÇÃO JUDICIAL. IMPUGNAÇÃO DE CREDOR. DESISTÊNCIA ANTES DE CONVOCADA A ASSEMBLÉIA-GERAL DE CREDORES. POSSIBILIDADE. 1. O credor pode desistir da objeção ao plano de recuperação judicial se o pedido de desistência tiver sido apresentado antes de convocada a assembléia-geral de credores. 2. Recurso especial provido. (...) A lei não prevê o procedimento a ser adotado caso o credor apresente objeção e posteriormente desista. Certo é que não existe nenhuma vedação à desistência, tampouco se pode obrigar a parte a prosseguir com a impugnação ao plano de recuperação judicial. Se o credor, voluntariamente, abriu mão do seu intento e julgou melhor acolher as condições postas no plano do devedor, não há por que não acolher a desistência apresentada."
\end{abstract}

Ainda acerca do tema, JULIO KAHAN MANDEL ${ }^{350}$ pondera que "antes de convocar a assembléia, pode o magistrado intimar o devedor a apresentar resposta e esclarecimentos à impugnação apresentada por credores isolados; com isso se dará oportunidade a uma rápida aprovação do plano já aprovado tacitamente pela maioria dos credores."

Discorda-se de tal entendimento, pois não raramente esses "esclarecimentos do devedor" ensejariam novas objeções, dando ensejo a tumulto processual. A lei, ademais, permite ao juiz fazer coisa diversa da convocação da AGC.

\title{
5.4.1.7. A objeção vincula o credor?
}

A despeito de ser ou não necessário fundamentar a objeção, caso o credor declare os seus motivos, ficará a eles vinculado? Quer dizer, ficará obrigado a rejeitar o plano na assembleia-geral de credores?

\footnotetext{
${ }^{349} 4^{\mathrm{a}}$ Turma, REsp. no 1.014.153-RN, Rel. Min. João Otávio de Noronha, j. 4.8.2011.

${ }^{350}$ Nova lei de falências e recuperação de empresas anotada. São Paulo: Saraiva, 2005, p. 125.
} 
A respeito do tema, MÁRCIO GUIMARÃES ${ }^{351}$ pondera o seguinte, ressaltando sua preocupação com os casos de credores que, mesmo tendo oferecido a objeção, deixam de comparecer à assembleia-geral de credores:

“...o credor que apresentar objeção deverá fazê-lo de forma responsável, ciente da conseqüência advinda da sua manifestação. Receosos ficamos com a existência de credores oferecendo objeção ao plano de recuperação, gerando a convocação de assembléia geral de credores, e, no dia da sua realização, o não-comparecimento. A conduta dos credores poderá, perfeitamente, acarretar sanções civis e criminais".

Em nossa opinião, não há nada que obrigue o credor a prender-se à objeção anteriormente formulada. Ao contrário, a convocação da assembleia-geral serve, dentre outras finalidades, justamente para tentar demover o credor da sua objeção, ou então procurar contorná-la. Portanto, não haveria óbice a que o credor aprovasse o mesmo plano que houvesse impugnado, ressalvada a responsabilidade por eventual abuso de direito.

\subsubsection{Efeitos da ausência de objeções}

Dispõe o art. 58, caput, da LRF que “o juiz concederá a recuperação judicial do devedor cujo plano não tenha sofrido objeção de credor nos termos do art. 55".

É preciso interpretar o dispositivo com atenção, pois a ausência de objeções nem sempre implicará a concessão da recuperação. Esta deverá ser negada caso o juiz reconheça: (i) a falta de alguma condição da ação ou de algum pressuposto de desenvolvimento válido do processo; (ii) a inexistência do direito subjetivo do devedor à recuperação (p. ex., em razão do desatendimento de um dos requisitos referidos nos incisos do art. 48 da LRF); (iii) a invalidade do plano de recuperação apresentado pelo devedor; (iv) a ocorrência de fraude, simulação ou colusão, além de outras coisas.

Conclui-se, portanto, que a ausência de objeção dos credores não dispensa o juiz de promover "juízo de legalidade" ${ }^{, 352}$ acerca do processo, do plano de recuperação e do direito do devedor, conforme leciona JORGE LOBO $^{353}$ :

${ }^{351}$ Comentários... Op. cit., p. 391-392. 
"O juízo da ação de recuperação judicial deve exercer, sempre, necessária e obrigatoriamente: $1^{\circ}$ ) o controle da legalidade formal, quando examinará questões, por exemplo, como: a) a legitimidade ativa (arts. $1^{\circ}$ e 47 ); preenchimento dos requisitos do art. 48; c) atendimento das exigências sobre convocação, instalação e deliberação da assembléia geral de credores (arts. 36 a 45); d) observância das formalidades legais referentes à publicação de editais; e, outrossim, $2^{\circ}$ ) o controle da legalidade material ou substancial, em que verificará se houve, por exemplo: a) fraude à lei ou abuso de direito, quer por parte do devedor, quer dos credores; b) acordos contrários à lei, à moral, aos bons costumes, à boa-fé objetiva, ao interesse público etc."

Indaga-se ainda se, na ausência de objeções ao plano, o juiz poderia submeter sua aprovação à Assembleia-Geral de Credores.

A esse respeito, MÁRCiO GuIMARÃEs ${ }^{354}$ afirma que, "não havendo manifestação de nenhum credor quanto ao plano apresentado, há possibilidade de, mesmo assim, o MP pugnar ou o próprio juízo da recuperação entender necessária a realização de assembléia geral de credores, designando dia para a sua realização.”

Essa posição, contudo, não tem sido acolhida, sobretudo porque a lei impõe ao juiz, na hipótese de não haver objeções, a imediata concessão da recuperação (LRF, art. 58, caput). Nesse sentido têm decidido os tribunais:

"Ocorre que a Lei $n^{\circ}$ 11.101/2005 é expressa no sentido de que, só haverá convocação de assembleia-geral de credores para deliberar sobre o plano recuperatório se houver objeção. Como não há dúvida de que não foi deduzida nenhuma objeção ao plano, a assembléia geral não poderia ter sido convocada e, muito menos, realizada, mercê do que, a deliberação dos cinco credores é ineficaz e não pode ser acolhida como objeção" ${ }^{355}$.

${ }^{352}$ Cf. EduARdo SECCHI MunHOZ. In: SOUZA JÚNIOR, Francisco Satiro de; PITOMBO, Antônio Sérgio de Moraes (Coords.). Comentários à Lei de Recuperação de Empresas e Falência. São Paulo: Revista dos Tribunais, 2005, p. 284.

${ }^{353}$ Comentários... Op. cit., p. 154.

${ }^{354}$ Comentários... Op. cit., p. 392.

${ }^{355}$ TJSP, Câm. Fal. e Recup., AI no 990.10.005006-0, Rel. Pereira Calças, j. 6.4.2010. 


\subsubsection{Controle judicial das objeções}

Feitas todas essas reflexões, é chegada a hora de tratar de um dos pontos mais polêmicos acerca do instituto versado no art. 55, caput, da LRF, qual seja, o controle judicial das objeções formuladas pelos credores, mais precisamente daquelas fundadas na contrariedade (= não aceitação) do plano de recuperação proposto pelo devedor ${ }^{356}$.

Para melhor compreender o assunto, convém antes estabelecer distinção entre os aspectos formais e materiais da objeção.

\section{(i) controle formal.}

Não há dúvida que, antes da convocação da Assembleia-Geral de Credores, o juiz deverá exercer controle formal ${ }^{357}$ da objeção manifestada pelo devedor.

Assim, competirá ao juiz examinar: (i) a regularidade da representação processual do credor, facultando-lhe prazo razoável para a correção de algum defeito (CPC, art. 13); e (ii) a tempestividade da objeção, mandando desentranhar aquelas apresentadas fora do prazo legal ${ }^{358}$, salvo se o credor comprovar não ter realizado o ato por justa causa.

Por outro lado, para aqueles que entendem que a objeção deve conter fundamentação, sua ausência também deverá ser objeto de controle formal pelo juiz, conforme assevera JOÃO BOSCO CASCARDO DE GOUVÊA ${ }^{359}$ : “por natural, também estou descartando a designação de assembléia quando a oposição ao plano for estéril, desarrazoada, vazia de conteúdo e, por isso mesmo, uma contradição: não se contesta apenas por contestar".

\footnotetext{
${ }^{356}$ Não se cuidará aqui, portanto, das objeções fundadas em matérias que o juiz poderia conhecer de ofício. 357 “Apresentada e apreciada formalmente objeção, o magistrado convoca a assembléia geral, devendo fazê-lo para data que não ultrapasse cento e cinquenta dias da data do deferimento do processamento pedido." (RICARDO NEGRÃO. A eficiência do processo judicial... Op. cit., p. 123-124).

${ }^{358}$ CPC, art. 183, caput: "decorrido o prazo, extingue-se, independentemente de declaração judicial, o direito de praticar o ato, ficando salvo, porém, à parte provar que o não realizou por justa causa”.

${ }^{359}$ Recuperação e Falência... Op. cit., p. 71.
} 


\title{
(ii) controle material.
}

Defendeu-se neste trabalho que o juiz tem competência para examinar a legitimidade do credor para oferecer a objeção ${ }^{360}$, cabendo-lhe rejeitá-la nas hipóteses em que verificar ausência de interesse na sua formulação (vide item 5.4.1.5). Outra questão diz respeito ao controle judicial do mérito da objeção, isto é, das razões que levaram o credor recusar o plano tal como proposto.

Acerca do tema, FÁBio UlHOA COELHO ${ }^{361}$, entre muitos outros doutrinadores $^{362}$, afirma que "não cabe ao juiz apreciar o conteúdo da objeção ou decidila. A competência para tanto é de outro órgão da recuperação judicial: a Assembléia de Credores. Desse modo, ao receber qualquer objeção, o juiz deve limitar-se a convocar a Assembléia”

Também é essa a orientação já consolidada da Câmara reservada à Falência e à Recuperação do Tribunal de Justiça de São Paulo, atualmente desmembrada em duas Câmaras Empresariais:

\begin{abstract}
"Recuperação judicial. Plano de recuperação judicial. Objeção apresentada. Decisão do juiz rejeitando a objeção e deferindo a recuperação judicial, com alteração do plano apresentado pelo devedor. Inadmissibilidade. Atividade do juiz que está limitada a verificar a legalidade da forma proposta para a recuperação, a observância das exigências legais para a realização da assembléia geral de credores e a aprovação do plano e a inocorrência de abuso de direito de um credor ou um grupo de credores em detrimento dos demais. Decisão anulada para que seja convocada a assembléia geral de credores" ${ }^{363}$.
\end{abstract}

\footnotetext{
${ }^{360}$ Para os fins deste trabalho, parece irrelevante discutir se o exame da legitimidade do credor inscreve-se no controle formal ou material da objeção.

${ }^{361}$ Comentários... Op. cit., p. 228.

362 SILVÂNIO COVAS igualmente reconhece "em relação à objeção, a nova lei limita a atuação do juiz à convocação da assembléia-geral, a qual deve apreciar o teor da manifestação dos credores e decidir sobre o plano de recuperação" (In: Comentários ...Op. cit, p. 301). Ainda nesse mesmo sentido, afirma NELSON RODRIGUES NETTO: "ressalvada a hipótese de falta de requisito da petição inicial, quando deverá ser indeferido o pedido, a assembléia-geral de credores é soberana para apreciar eventuais objeções e deliberar sobre o plano de recuperação, aceitando-o ou rejeitando-o." (Comentários... Op. cit., p. 107).
}

${ }^{363} \mathrm{AI} \mathrm{n}^{\mathrm{o}}$ 482.851-4/4-00, Rel. Des, Boris Kauffmann, j. 25.4.2007. 
Para RICARDO NEGRÃO ${ }^{364}$, todavia, caberia ao juiz decidir sobre a pertinência da objeção do credor, mesmo quando versar sobre o conteúdo do plano, sua inviabilidade técnica ou a inexatidão dos laudos e pareceres técnicos:

"Qualquer credor pode manifestar sua objeção, podendo livremente
argüir ausência de requisitos formais, bem como matéria relativa ao
conteúdo do plano, tais como inviabilidade técnica, sacrifício dos
credores superior à liquidação na falência, inexatidão dos laudos e
pareceres técnicos, existência de fraude ou crime praticado anterior ou
simultaneamente ao pedido, etc. Cabe ao juiz decidir sobre a
pertinência da manifestação."

Essa opinião é compartilhada por JULIO KAHEL MANDEL ${ }^{365}$, que sustenta competir ao juiz analisar não apenas a relevância da objeção, mas a própria relevância do crédito titulado pelo impugnante. Para ele, a oposição do titular de crédito de pouca relevância não justificaria os custos de dinheiro e tempo com a convocação da assembleia:

"Havendo oposição relevante de um credor, deve ser convocada a
assembléia para deliberar pela aceitação ou não do plano. Contudo,
pelo atraso na aprovação do plano que a convocação geraria, assim
como pelos custos envolvidos, entendo que o juiz deve analisar a
relevância do crédito e a justificativa do pedido antes de convocar a
assembléia. Com essa cautela, a execução de um plano aprovado
tacitamente pela esmagadora maioria dos credores não ficará
paralisada pela impugnação de um credor que represente porcentagem
ínfima do passivo da empresa em recuperação, nem permitirá que se
usem estratagemas de pressão por parte de credores, que somente têm
a finalidade de criar dificuldades ao devedor para solicitar
facilidades."

Finalmente, JORGE LOBO ${ }^{366}$ defende que, caso a objeção formulada pelo credor venha a ser rejeitada pela AGC, caberá então ao juiz apreciá-la, decidindo-lhe o mérito:

"Se a assembléia geral rejeitar a objeção, o credor poderá peticionar ao juízo da recuperação, pleiteado que a examine e sobre ela decida quando for proferir sentença na forma do art. 58, visto que a Constituição Federal, no art. $5^{\circ}$, XXXIV, a, XXXV e LV, e o princípio da economia e da efetividade do processo garantem irrestrito acesso ao Poder Judiciário."

\footnotetext{
${ }^{364}$ A eficiência do processo judicial... Op. cit., p. 123-124.

${ }^{365}$ Nova lei de falências... Op. cit., p. 125.

${ }^{366}$ Comentários... Op. cit., p. 149.
} 
Respeitados os entendimentos contrários, parece mais acertado que o controle material das objeções dos credores, ressalvada a questão da legitimidade, seja reservado exclusivamente à assembleia-geral. Entender-se o contrário significa ignorar o sistema da structured bargaining a que a lei concursal brasileira claramente se filiou, fazendo letra morta dos arts. 45,56 e 58 da LRF.

Permitir que o juiz decida as objeções dos credores, antes ou depois da deliberação dos credores, significa alijar a AGC da sua competência legal, o que é inadmissível. Ressalve-se, porém, que isso não impede o juiz de exercer o controle da legalidade das deliberações assembleares, em especial para repelir eventual abuso de direito dos credores.

\subsubsection{Convocação a pedido do administrador judicial}

Dispõe a lei que o administrador judicial, enquanto órgão auxiliar ${ }^{367}$ do juiz, tem competência para requerer ao juiz a convocação nos casos previsto em lei ou quando entender necessária sua ouvida para a tomada de decisões (LRF, art. 22, I, "g").

É desprovida de sentido a previsão legal que confere ao administrador judicial competência para requerer ao juiz a realização da AGC “nos casos previstos em lei”, já que a convocação, nesses $\operatorname{casos}^{368}$, deve ser feita independentemente de qualquer manifestação sua. Tal disposição só faria sentido se o administrador judicial tivesse competência para, sozinho, convocar a AGC, o que seria preferível segundo a opinião de HAROLDO MALHEIROS DUCLERC VERÇOSA ${ }^{369}$ :

\footnotetext{
367 "O administrador judicial da recuperação é órgão auxiliar do Juiz, que o nomeia (art. 52, I) e o fiscaliza diretamente, nos termos do caput do art. 22 (como o comissário, no regime anterior), podendo, simultaneamente, funcionar como órgão de fiscalização do devedor e do cumprimento do plano em regime dual, caso seja criado o Comitê de Credores" (MAURo Rodrigues PENTEADO. In: CORRÊA-LIMA, Osmar Brina; e LIMA, Sérgio Mourão Correa (coord.). Comentários à nova Lei de Falência e Recuperação de Empresa. Rio de Janeiro: Forense, 2009, p. 168).

${ }^{368}$ Seja em razão de objeção ao plano de recuperação, afastamento do devedor ou de pedido de credores representantes de $25 \%$ dos créditos de determinada classe ou ainda do Comitê de Credores, a convocação da AGC é medida que se impõe ao juiz.

369 In: SOUZA JÚNIOR, Francisco Satiro de; PITOMBO, Antônio Sérgio de Moraes (Coords.). Comentários... Op. cit., p. 170.
} 
“... a fim de evitar mais este ato de natureza burocrática que acarretará a perda de um tempo precioso, melhor teria feito a Lei se houvesse outorgado tal competência ao próprio administrador judicial, comunicando-se o juiz a esse respeito".

Registre-se ainda que, conquanto possa contar com o auxílio de profissionais ou empresas especializadas (LRF, art. $7^{\circ}$, in fine $)^{370}$, não é dado ao administrador judicial delegar suas atribuições a terceiros ${ }^{371}$, de modo que somente ele poderá requerer a convocação da AGC nos casos em que reputar necessário ouvir os credores acerca de determinadas decisões, como, p. ex., sobre a conveniência da manutenção de certos contratos bilaterais ou do cumprimento de contratos unilaterais do devedor em caso de falência, a fim de preservar os ativos ou reduzir o passivo, notadamente se não tiver sido constituído o Comitê de Credores (LRF, arts. 117 e 118) ${ }^{372}$.

\subsubsection{Convocação a pedido do Comitê de Credores}

O Comitê de Credores também tem competência para requerer ao juiz a convocação da Assembleia-Geral de Credores (LRF, art. 27, I, “e”). O exercício dessa atribuição se justifica, p. ex., quando o órgão entender ser conveniente a convolação da recuperação judicial em falência, a aprovação de forma alternativa de realização do ativo, ou a deliberação dos credores sobre quaisquer outras matérias de competência exclusiva da $\mathrm{AGC}^{373}$.

\footnotetext{
${ }^{370}$ Art. $7^{\circ}$. A verificação dos créditos será realizada pelo administrador judicial, com base nos livros contábeis e documentos comerciais e fiscais do devedor e nos documentos que lhe forem apresentados pelos credores, podendo contar com o auxílio de profissionais ou empresas especializadas.

${ }^{371}$ Em que pese a omissão da lei a respeito - que não se via no regime do Dec.-Lei no 7.661/45 (art. 61) prevalece na doutrina que as funções do administrador judicial são indelegáveis, tais como eram as funções do síndico: "Ora, a faculdade do administrador judicial de "contar com o auxílio de profissionais ou empresas especializadas' (...) evidentemente não significa delegar funções - que são, frise-se, personalíssimas - mas, sim, obter assessoria para o desempenho das respetivas funções" (Mario Sergio Milani. Lei de recuperação judicial... Op. cit., p. 134).

${ }^{372}$ Art. 117. Os contratos bilaterais não se resolvem pela falência e podem ser cumpridos pelo administrador judicial se o cumprimento reduzir ou evitar o aumento do passivo da massa falida ou for necessário à manutenção e preservação de seus ativos, mediante autorização do Comitê.

Art. 118. O administrador judicial, mediante autorização do Comitê, poderá dar cumprimento a contrato unilateral se esse fato reduzir ou evitar o aumento do passivo da massa falida ou for necessário à manutenção e preservação de seus ativos, realizando o pagamento da prestação pela qual está obrigada.

${ }^{373}$ Cf. PAULO F. C. SALLES DE TOLEDO: "também não se atribuiu ao comitê de credores legitimidade para requerer a convolação da recuperação judicial em falência. (...) poderá o comitê pleitear a convocação de assembleia geral, que poderá deliberar a respeito". (In: Comentários... Op. cit., p. 130).
} 


\subsubsection{Convocação a pedido dos credores}

Conforme o art. $36, \S 2^{\circ}$, da LRF, credores que representem, no mínimo, $25 \%$ do valor total dos créditos de uma determinada classe, segundo a ordem de distribuição prevista no art. 41 da LRF, poderão requerer ${ }^{374}$ ao juiz, a qualquer tempo ${ }^{375}$, a convocação da AGC, a fim de deliberar sobre qualquer matéria de interesse dos credores, inclusive para constituir o Comitê ou substituir seus membros (LRF, art. 52, § $2^{\circ}$ ).

\subsubsection{Convocação em razão do afastamento do devedor}

Conforme tratado no item 4.1.4 acima, o juiz poderá afastar da condução da empresa o devedor que tenha incorrido em alguma das condutas descritas no art. 64 da LRF, hipótese em que nomeará um gestor judicial, segundo indicação da AGC. Assim, na mesma decisão que determinar o afastamento do devedor, deverá o juiz convocar a assembleia para deliberar sobre o nome do gestor judicial que assumirá a administração das atividades do devedor ${ }^{376}$ (LRF, art. 65, caput).

Note-se que, enquanto a indicação do nome do gestor compete exclusivamente à AGC, sua nomeação é ato privativo do juiz, que deverá denegá-la em caso de impedimento $^{377}$ da pessoa indicada.

\footnotetext{
374 "Registre-se que aos credores legalmente habilitados não é facultado convocar a assembleia geral, mas tão-somente requerer sua convocação ao juiz, que deverá assim proceder, em obediência às determinações da Lei Falimentar" (MODESTO CARVALHOSA. In: Comentários à nova lei de falência... Op. cit., p. 266).

375 Mas somente depois de deferido o processamento do pedido de recuperação judicial ou decretada a falência.

376 Enquanto não for nomeado o gestor judicial, suas funções serão provisoriamente exercidas pelo administrador judicial (LRF, art. 65, $\S 1^{\circ}$ ).

377 Apesar do silêncio da lei a respeito, entende-se que as hipóteses de impedimento aplicáveis ao administrador judicial e aos membros do Comitê se estendem ao gestor judicial. Nesse sentido, confira-se a lição de JORGE LOBO: "Não podem assumir o cargo de gestor judicial pessoas impedidas por lei especial ou condenadas por crime falimentar, de prevaricação, peita ou suborno, concussão, peculato, contra a economia popular, a fé pública ou a propriedade, ou a pena criminal que vede, ainda que temporariamente, o acesso a cargos públicos (LSA, art. 147, $\S 1^{\circ}$, e CC, art. $1.011, \S 1^{\circ}$ ), bem como as que, nos últimos cinco anos, no exercício do cargo de administrador judicial, ou de membro do comitê de credores foram destituídas nos autos da falência ou recuperação judicial anterior, deixaram de prestar contas dentro dos prazos legais ou tiveram a prestação de contas desaprovada ou tiverem relação de parentesco ou afinidade até o terceiro grau com o devedor, seus administradores, controladores ou representantes legais, ou deles forem amigos, inimigos ou dependentes (art. 30, caput e $\S 1^{\circ}$ )". (In: Comentários... Op. cit., p. 241).
} 
Caso o gestor indicado pela AGC recuse ou esteja impedido de aceitar o encargo, o juiz convocará nova assembleia-geral, no prazo de 72 (setenta e duas) horas, contado do conhecimento da recusa ou da declaração do impedimento nos autos (LRF, art. $\left.65, \S 2^{\circ}\right)$.

A lei não prevê, todavia, a convocação da AGC para a substituição do gestor salvo nas hipóteses de recusa e impedimento. Ou seja, não conferiu à AGC a competência para substituir o gestor nomeado por mera discricionariedade dos credores $^{378}$, o que é positivo em termos de estabilidade da administração.

Logicamente, em caso de incompetência administrativa ou de faltas do gestor nomeado, os credores poderão requerer ao juiz a sua destituição. Desde que acolhidas as razões dos credores, o juiz convocará nova assembleia para a escolha de novo gestor. Ainda assim, essa substituição deverá se submeter ao crivo judicial.

\subsubsection{Convocação por conveniência do juiz}

A última hipótese de convocação vem prevista no art. 99, XII, da LRF. Esse dispositivo estabelece que a sentença que decretar a falência do devedor, dentre outras determinações, "determinará, quando entender conveniente, a convocação da assembléiageral de credores para a constituição de Comitê de Credores, podendo ainda autorizar a manutenção do Comitê eventualmente em funcionamento na recuperação judicial quando da decretação da falência”.

Especialmente na falência de grandes devedores, o juiz poderá entender conveniente a constituição do Comitê para que os interesses dos credores sejam mais bem representados e que se proceda a uma maior fiscalização dos ativos e dos agentes que participam do processo falimentar.

\footnotetext{
378 Diferentemente, ao tratar dos membros do Comitê de Credores, a lei expressamente atribui à AGC competência para deliberar a substituição dos seus membros (LRF, art. 35, I, “b”, e II, “b”). Aliás, nem é preciso a convocação da assembleia para se proceder a essa substituição, bastando seja formulado requerimento escrito nesse sentido subscrito por credores que representem a maioria da classe que elegeu o representante (LRF, art. 26, § $6^{\circ}$ ).
} 
A literalidade do art. 99, XII, permitiria concluir que o juiz tem o poder de impor coativamente aos credores a constituição do comitê. Quando muito, porém, o juiz poderá provocá-los a fazê-lo, mas a decisão de constituir ou não esse órgão, mesmo na falência, é privativa da $\mathrm{AGC}^{379}$ (LRF, art. 35, II, 'b”), até porque a remuneração dos seus membros não é custeada pelo devedor ou pela massa, e sim pelos próprios credores (LRF, art. 29).

\section{Instalação da assembleia}

A instalação da Assembleia-Geral de Credores demanda certos procedimentos preparatórios $^{380}$, além da regular convocação. Consistem, basicamente, $(i)$ na colheita das assinaturas dos credores na lista de presença (a partir da qual será verificado se foi atingido o número mínimo de credores exigido pela lei, caso se trate de primeira convocação); e (ii) na formação da mesa, com a nomeação do secretário, entre um dos credores, pelo presidente do conclave (em regra, o administrador judicial).

O art. 37, § $2^{\circ}$, da LRF dispõe sobre o quórum de instalação ${ }^{381} 382$ da AGC, exigindo, em primeira convocação, a presença de credores titulares de mais da metade dos créditos de cada classe, computados pelo valor. Isso é feito como forma de conferir maior legitimidade às deliberações tomadas ${ }^{383}$.

${ }^{379}$ Cf. AdALBERTO Simão FilHo, “... o juiz determinará que se convoque a assembléia de credores para a constituição do Comitê de Credores. Este fato não leva à crença de que a Assembléia compulsoriamente deva constituir um Comitê desta natureza, mas, sim, que deve se reunir em conclave e deliberar na tentativa de eleição. Caso tenha sido infrutífera a eleição, o fato será comunicado ao Juiz que passará as funções do Comitê ao administrador judicial e, na incompatibilidade deste, estas serão exercidas pelo próprio juízo à luz do art. 28 da LRF" (In: DE LUCCA, Newton; e SIMÃO FILHO, Adalberto. Comentários à Nova Lei de Recuperação de Empresas e Falências. São Paulo: Quartier Latin, 2005, p. 446).

380 Cf. RICARDo TEPEDINO. In: LAMY FILHO, Alfredo; e BULHÕES PEDREIRA, José Luiz (Coords.). Direito das Companhias. Rio de Janeiro: Forense, 2009, v. 1, p. 912.

381 “O quórum, também chamado de número legal, expressão que se origina na doutrina italiana, exprime ... uma exigência mínima de presenças válidas 'para que um corpo colegial possa instaurar qualquer processo deliberativo’, como ensina Pinto Furtado (1999, p. 114 e 119)” (RICARDo TEPEDINO. Idem, p. 913).

382 O quórum de instalação não se confunde com quórum de deliberação: o primeiro exige um número mínimo de credores para que a AGC ocorra validamente, "enquanto que o segundo diz respeito aos votos necessários para a aprovação de determinada matéria, obedecendo ao princípio majoritário ou a quorum qualificado estabelecido na lei” (cf. ARNOLDO WALD. Comentários ao novo código civil. Coord. de Sálvio de Figueiredo Teixeira. Do direito de empresa. Rio de Janeiro: Forense, 2005, v. 19, p. 497).

383 Aplicam-se aqui as lições de MODESTO CARVALHOSA em relação às assembleias da sociedade anônima: "Ainda que a assembléia geral seja um órgão deliberativo colegiado que tem obrigação de decidir assuntos do interesse social em qualquer circunstância, dentro de sua competência, não se pode negar a evidência de que para a formação dessa vontade coletiva deve haver, pelo menos, numa primeira tentativa, a aglutinação de um 
A obtenção desse quórum é verificada a partir das assinaturas dos credores lançadas na lista de presença, que será encerrada justamente no momento da instalação do conclave (LRF, art. $\left.37, \S 3^{\circ}\right)^{384}$.

Não alcançado o número mínimo legal, a AGC poderá ser instalada em segunda convocação ${ }^{385}$ com qualquer número, pois não é razoável postergar indefinidamente a deliberação em face de reiterado desinteresse dos credores com a crise da empresa.

Ou seja, para que seja instalada a assembleia na data designada em primeira convocação, é necessário que estejam presentes credores titulares de mais da metade dos créditos de cada uma das três classes segundo a distribuição determinada pelo art. 41 da LRF, exceto quando o conclave tiver por objeto a constituição do Comitê de Credores ${ }^{386}$, a escolha ou a substituição dos seus membros, hipóteses em que deverá ser observada a divisão prevista no art. 26 da LRF, conforme explicado no item 3, acima.

Por óbvio, só será necessária a presença de um número mínimo de credores de alguma das três classes se houver créditos que nelas se enquadrem. Vale dizer, se o devedor não tiver dívidas trabalhistas ou decorrentes de acidente do trabalho, não se cogita da necessidade de nenhum empregado para instalar a assembleia. $\mathrm{O}$ mesmo se diga no caso de inexistirem créditos com garantia real.

Note-se ainda que só serão admitidos a participar da AGC - e computados para fins de verificação do quórum de instalação - aqueles que tenham a condição de credor

valor significativo do capital social representado pela presença dos respectivos titulares. Se intransponível o absenteísmo, em sua segunda tentativa, essa vontade social será expressa de qualquer forma por aqueles acionistas detentores de qualquer percentual que se dispuserem a declará-la" (Comentários à Lei de Sociedades Anônimas. 3 ed. São Paulo: Saraiva, 2003, v. 2, p. 676).

${ }^{384}$ Art. 37, § $3^{\circ}$. Para participar da assembléia, cada credor deverá assinar a lista de presença, que será encerrada no momento da instalação.

${ }^{385}$ A AGC não poderá ser realizada, em segunda convocação, menos de cinco dias depois da primeira (LRF, art. 36, I).

${ }^{386}$ Referindo-se ao art. 37, $\S 2^{\circ}$, da LRF, assim se manifesta MARLON TOMAZETTE: “A nosso ver, salvo nos casos de constituição e eleição do comitê, as classes aqui são aquelas mencionadas no artigo 41 da Lei $\mathrm{n}^{\circ}$ 11.101/2005" (Curso de Direito Empresarial... Op. cit., p. 135). 
reconhecida no processo segundo a fase em que este se encontra, conforme estabelece o art. 39, caput, da $\mathrm{LRF}^{387}$.

De sorte que a verificação do quórum de instalação será feita em consideração às pessoas arroladas no quadro-geral de credores $^{388} \mathrm{ou}$, na sua falta, na relação de credores apresentada pelo administrador judicial na forma do art. $7^{\circ}, \S 2^{\circ}$, da LRF, ou, ainda, na falta desta, na relação apresentada pelo próprio devedor com a petição inicial do pedido de recuperação (LRF, art. 51, III e IV), com o pedido de autofalência (LRF, art. 105, II) ou em cumprimento da sentença de quebra (LRF, art. 99, III), acrescidas, em qualquer caso, das pessoas que estejam habilitadas na data da realização da assembleia ou que tenham créditos admitidos ou alterados por decisão judicial, inclusive as que tenham obtido reserva de importâncias, observado o disposto nos $\S \S 1^{\circ}$ e $2^{\circ}$ do art. 10 da LRF.

Ressalte-se, por fim, que o número mínimo de credores previsto no art. 37, § $2^{\circ}$, da LRF somente é exigido no momento da instalação da AGC, sendo irrelevante a sua manutenção depois de iniciados os trabalhos. Assim, o fato de um ou mais credores se retirarem do recinto depois de assinada a lista de presença não tem importância para a verificação do quórum de instalação, que é feita com base na lista de presença. Isso se presta a evitar manobras oportunistas de alguns credores, como para obstruir deliberação que caminha em sentido contrário às suas pretensões.

A esse respeito, ressalva-se a opinião de Modesto CARVALHOSA, para quem a validade da AGC depende da manutenção do quórum de instalação durante todo o conclave $^{389}$, mesmo entendimento que adota em relação às assembleias da sociedade anônima $^{390}$. Não se trata, todavia, de posição acolhida pela maioria da doutrina ${ }^{391}$.

\footnotetext{
${ }^{387}$ Esse dispositivo se acha explicado em detalhes nos itens 2.1 e 2.2, acima.

${ }^{388} \mathrm{O}$ quadro-geral de credores constitui documento assinado pelo juiz e pelo administrador judicial que menciona a importância e classificação de cada crédito na data do requerimento da recuperação judicial, que será juntado aos autos e publicado no órgão oficial, no prazo de 5 dias, contado da data da sentença que houver julgado as impugnações (LRF, art. 18, par. único).

389 “O quórum registrado na lista de presença deve subsistir durante toda a reunião e manter-se no momento da votação. Por conseguinte, a exigência de quórum deliberativo não deve ser apenas satisfeita na instalação da assembléia, mas mantida e respeitada durante todo o curso das deliberações." (In: Comentários à nova lei de falência... Op. cit., p. 271).

${ }^{390}$ Com praticamente as mesmas palavras transcritas na nota acima, confira-se: Comentários à Lei de Sociedades Anônimas... Op. cit., p. 674.
} 


\subsection{Quórum de instalação na recuperação judicial}

O art. $39, \S 1^{\circ}$, da LRF, estabelecendo que não terão direito a voto e não serão considerados para fins de verificação do quórum de instalação e deliberação os titulares de créditos excetuados dos efeitos da recuperação judicial na forma dos $\S \S 3^{\circ}$ e $4^{\circ}$ do art. 49 da mesma lei ${ }^{392}$. Embora o dispositivo não faça nenhuma distinção, a exclusão desses credores só deve ocorrer nas assembleias realizadas durante a recuperação judicial ${ }^{393}$, já que não são imunes à falência do devedor ${ }^{394}$.

Por outro lado, o art. 43, caput, da LRF estabelece que também não terão direito a voto, nem serão considerados para fins de verificação do quórum de instalação e de deliberação os sócios do devedor ${ }^{395}$ e as sociedades com vinculação societária relevante com o devedor ou seus sócios ${ }^{396}$. O mesmo vale para o cônjuge ou parentes até o segundo grau do devedor, seu sócio controlador, seus administradores, membros dos seus conselhos fiscais, consultivos ou semelhantes, e ainda para as sociedades onde tais pessoas exerçam

391 Cf. Alfredo SÉRgio LAZZARESCHI Neto, "O que importa é o quórum no momento da instalação da assembleia, sendo irrelevante a sua manutenção até o término dos trabalhos.” Lei das Sociedades por Ações anotada... Op. cit., p. 317). No mesmo sentido, invocando as lições de Cunha Peixoto, assim se manifesta RICARDO TEPEDINO: "Resta examinar se o quorum de instalação deve se conservar ao longo de toda a reunião - i.e., se o conclave será antecipadamente encerrado diante da constatação de que o número legal verificado quando da instalação deixou de existir num determinado momento, porque alguns acionistas se retiraram em meio à reunião, conforme defende Carvalhosa (...). A resposta negativa, no entanto, se impõe diante da clareza do texto legal, que só exige um quorum específico para instalar a Assembléia em primeira convocação, e, quando quer um percentual mínimo de votos para a aprovação de determinada matéria, faz expressa exigência, como se lê no artigo 136 da LSA” (Direito das Companhias... Op. cit., p. 916).

392 Quais sejam, os credores titulares da posição de proprietário fiduciário de bens móveis ou imóveis, de arrendador mercantil, de proprietário ou promitente vendedor de imóvel cujos respectivos contratos contenham cláusula de irrevogabilidade ou irretratabilidade, inclusive em incorporações imobiliárias, ou de proprietário em contrato de venda com reserva de domínio, bem como os titulares de créditos decorrentes de adiantamento a contrato de câmbio para exportação.

393 “O dispositivo é aplicável unicamente às Assembléias que se realizarem durante a recuperação judicial, pois os créditos apontados - decorrentes de alienação fiduciária, arrendamento mercantil, promessa de venda e compra de imóvel com cláusula de irrevogabilidade ou irretratabilidade, contrato de venda com reserva de domínio e adiantamento a contrato de câmbio para exportação - não se submetem aos seus efeitos $\left(\S \S 3^{\circ}\right.$ e $4^{\circ}$ do art. 49)" (ERASMO VAlladÃo FranÇA. In: Comentários... Op. cit., p. 210).

394 Não parece possível excluir da AGC, durante a falência, nem mesmo os credores que fazem jus à restituição (LRF, art. 86), como é o caso do crédito decorrente de ACC, pelo menos até que a restituição tenha sido realizada, na medida em que as deliberações tomadas pelos demais credores poderão influenciar na restituição daquilo que lhes é devido, notadamente nas hipóteses em que o pagamento desses credores depender da venda dos ativos do devedor.

${ }^{395}$ Na hipótese de o devedor ser uma sociedade empresária.

${ }^{396}$ Sociedades coligadas, controladoras, controladas ou as que tenham sócio ou acionista com participação superior a $10 \%$ (dez por cento) do capital social do devedor ou em que o devedor ou algum de seus sócios detenham participação superior a $10 \%$ (dez por cento) do capital social. 
essas funções (LRF, art. 43, p.u.). Note-se que aqui se cuida de credores sujeitos aos efeitos da recuperação, mas privados do direito de voto, em razão do que não serão computados para fins de verificação do quórum de instalação.

A partir desses dispositivos (art. 39, $\S 1^{\circ}$ e art. 43) pode-se traçar uma regra geral para definir quais credores, dentro do universo daqueles reconhecidos segundo a fase do processo, não serão computados para a verificação do quórum de instalação. Em síntese, não serão computados nesse quórum todos os credores imunes aos efeitos da recuperação ${ }^{397}$ ou simplesmente privados do direito de voto.

É verdade que, no tocante a outros créditos imunes aos efeitos da recuperação (além daqueles mencionados no art. 39, $\S 1^{\circ}$, da LRF), a lei não contém disposição que os exclua do quórum de instalação. Assim como existem credores privados do direito de voto (além daqueles referidos no art. 43 da LRF) que também não foram expressamente excluídos dessa contagem.

Não há, por exemplo, artigo que exclua do quórum de instalação os débitos fiscais ou as obrigações assumidas no âmbito das câmaras ou prestadoras de serviços de compensação e de liquidação financeira, não sujeitas aos efeitos da recuperação (LRF, art. 193). Da mesma forma que não há artigo que disponha que os credores retardatários, privados do direito de voto em certas condições (LRF, art. $\left.10, \S 1^{\circ}\right)^{398}$, não são considerados para efeito de verificação do quórum de instalação.

Esse "silêncio" da lei não significa que o legislador quisesse que tais créditos, não obstante excluídos dos efeitos da recuperação ou privados do direito de voto, fossem computados no quórum de instalação da AGC. Cuida-se, à evidência, de má técnica legislativa, que há de ser superada por meio da interpretação sistemática ${ }^{399}$.

\footnotetext{
${ }^{397}$ A rigor, aqueles credores excluídos dos efeitos da recuperação não serão computados porque não podem votar, de modo que se poderia resumir a regra geral nos seguintes termos: não serão computados para verificação do quórum de instalação os credores sem direito de voto.

398 Art. 10, § $1^{\circ}$. Na recuperação judicial, os titulares de créditos retardatários, excetuados os titulares de créditos derivados da relação de trabalho, não terão direito a voto nas deliberações da assembléia-geral de credores.

399 Portanto, deve-se entender que, por não se submeterem aos efeitos da recuperação, não terão nenhuma relevância para a verificação do quórum de instalação os créditos fiscais (LRF, arts. $6^{\circ}, \S 7^{\circ}, 57$ e 68 e CTN, art. 187) e aqueles relativos a obrigações assumidas no âmbito das câmaras ou prestadoras de serviços de
} 
Onde existe a mesma razão fundamental, prevalece a mesma regra de direito $^{400}$, especialmente porque a lógica determina que só sejam considerados para efeito de instalação os credores com direito a voto, tal como é na sociedade anônima.

Com efeito, os arts. 125, caput, e 135, caput, da Lei das S.A. condicionam a instalação da assembleia-geral à presença de acionistas representantes de certos percentuais do capital social com direito de voto, porque não faz nenhum sentido subordinar a sua validade à presença de acionistas que não poderão $\operatorname{votar}^{401}$.

A reforçar esse entendimento, note-se que mesmo as ações que conferem direito de voto não serão computadas para efeito de instalação da assembleia caso se achem depositadas em tesouraria (LSA, art. $30, \S 4^{\circ}$ ) ou se seus titulares se acharem com os direitos suspensos (LSA, art. 120) ${ }^{402}$.

Situação peculiar diz respeito ao art. $45, \S 3^{\circ}$, da LRF, que dispõe o seguinte: "O credor não terá direito a voto e não será considerado para fins de verificação de quorum de deliberação se o plano de recuperação judicial não alterar o valor ou as condições originais de pagamento de seu crédito”.

Isso significa que esse credor não terá direito de voto somente na deliberação sobre o plano de recuperação que não tenha alterado o valor ou as condições originais de pagamento do seu crédito $^{403}$, de modo que poderá votar em qualquer outra matéria

compensação e de liquidação financeira (LRF, arts. 193 e 194). Da mesma forma que não deverão ser computados nesse quórum os créditos titularizados por pessoas sem direito de voto.

400 "Ubi eadem ratio, ibi eadem legis dispositio" (cf. CARLos MAXIMILIANO. Hermenêutica e aplicação do direito... Op. cit., p. 245).

${ }^{401}$ Cf. WiLSON DE SOUZA CAMPOS BatAlHA, com fundamento nas lições de Ascarelli: "tanto para efeito do quórum, como para efeito do cálculo das maiorias não se computam as ações sem direito de voto" (Comentários à Lei das Sociedades Anônimas. Rio de Janeiro: Forense, 1977, v. 2, p. 602).

402 "Para o cálculo do quórum de instalação e de deliberação, não serão levadas em conta as ações mantidas em tesouraria pela companhia, tendo em vista o disposto no art. 30 , $\S 4^{\circ}$, bem como as ações cujos direitos foram suspensos pela assembleia geral nos termos do art. 120" (ALFREDO SÉRGIO LAZZARESCHI NETO. Lei das Sociedades por Ações anotada... Op. cit., p. 317).

${ }^{403} \mathrm{O}$ art. $45, \S 3^{\circ}$, da LRF parte do duvidoso pressuposto de que esse credor não teria interesse na deliberação sobre o plano, já que o recebimento do seu crédito não seria atingido. A doutrina critica fortemente esse dispositivo, salientando que, mesmo na hipótese de as condições de pagamento não serem alteradas, as medidas constantes do plano de recuperação poderiam comprometer a segurança do recebimento do crédito, o que ensejaria o interesse desse credor na deliberação. Entre outros, assim leciona FÁBIO UlHOA COELHO: 
constante da mesma ordem do dia ou que seja objeto de outra assembleia. Não se trata, portanto, de credor sem direito de voto, mas de credor impedido de votar determinada matéria.

A lei dispõe que esse credor não será considerado para fins de verificação de quórum de deliberação, mas silencia no tocante ao quórum de instalação, o que levou ERASMO VALLADÃo FRANÇA a afirmar que "o crédito em questão é computado apenas para fins de instalação, mas não de deliberação”.

A questão é delicada, não sendo de todo desarrazoado defender a irrelevância, para a instalação da assembleia, da presença do credor impedido de votar a aprovação do plano de recuperação, quando esta seja a única matéria da ordem do dia ${ }^{404}$.

Considerando-se, no entanto, que a competência da AGC não se limita à aprovação ou rejeição do plano, cabendo-lhe também modificá-lo, é possível que, no curso do conclave, o credor inicialmente impedido de votar passe a ter direito de voto, quando a modificação em debate alterar as condições do recebimento do seu crédito.

Por conta disso, talvez seja melhor admitir que o credor impedido de votar nos termos do art. $45, \S 3^{\circ}$, da LRF seja mesmo computado na verificação do quórum de instalação, valendo lembrar que, nas assembleias da sociedade anônima, tem prevalecido o entendimento de que as ações de titularidade dos acionistas impedidos de votar certas matérias (por conta de conflito formal) podem ser contabilizadas para fins de instalação do conclave, embora não sejam computadas no quórum de deliberação ${ }^{405}$.

\footnotetext{
"Essa exclusão da base de cálculo do quórum de deliberação do Plano justifica-se no pressuposto da lei de que o credor não atingido pela proposta de reorganização da empresa não teria nenhum interesse no resultado da votação. Tal pressuposto é questionável porque, mesmo não sendo atingido diretamente pela proposta em votação, é claro que o credor pode ter o seu direito ameaçado na hipótese de aprovação de um plano inconsistente, que não leve à efetiva recuperação do devedor" (Comentários... Op. cit., p. 156).

${ }^{404}$ Em tese, também seria possível defender que, constando da ordem do dia outras matérias em que o credor não está impedido de votar, seria necessário verificar separadamente o quórum de instalação para cada deliberação. Esta é a solução dada à assembleia da S.A. para o caso de, numa mesma pauta, haver matéria em que votam os preferencialistas e outra nas quais só votam as ações ordinárias: "Quid juris se a mesma pauta contiver matéria para a qual os preferencialistas estão aptos a deliberar e outra onde suas ações não desfrutam do direito de voto? Parece só haver uma única solução: o quórum de instalação será verificado separadamente para ambos os casos. Se num deles não se alcançar o número legal, o respectivo tema não será levado a deliberação" (RICARDO TEPEDINO. Direito das Companhias... Op. cit., p. 914).

${ }^{405}$ Cf. AlFREDO SÉRGIO LAZZARESCHI NETO, “o acionista impedido de votar pode comparecer à assembleia e discutir livremente as matérias submetidas a deliberação (...), não podendo, contudo, exercer o direito de
} 


\title{
6.2. Quórum de instalação na falência
}

A diferença fundamental do quórum de instalação da AGC realizada na falência é que, para a sua verificação, também serão levados em consideração alguns créditos excluídos dos efeitos da recuperação, como aqueles referidos nos $\S 3^{\circ}$ e $4^{\circ}$ do art. 49. Aqui, comporão o quórum de instalação e terão direito de voto os credores titulares da posição de proprietário fiduciário de bens móveis ou imóveis, arrendador mercantil, proprietário ou promitente vendedor de imóvel cujos respectivos contratos contenham cláusula de irrevogabilidade ou irretratabilidade, proprietário em contrato de venda com reserva de domínio, ou ainda de créditos decorrentes de ACC.

Note-se ainda que, não obstante sujeitos aos efeitos da falência, os créditos fiscais - segundo o entendimento dominante - também não serão computados no quórum de instalação:

\begin{abstract}
"Como o fisco não tem direito a voto na assembleia-geral de credores na falência, não deve, em consequência, ser considerado para fins de verificação de quórum de instalação e deliberação, nos termos do disposto nos arts. 45, § $3^{\circ}$, e $39, \S 1^{\circ}$, da Lei 11.101/2005. Quanto à forma de liquidação aprovada pela assembleia geral, pela mesma razão que essa deliberação não pode prejudicar credores, também não poderia modificar os direitos e privilégios do crédito tributários" (LUIS Felipe Salomão e Paulo Penalva Santos) ${ }^{406}$.
\end{abstract}

O mesmo se diga em relação a todos os credores privados do direito de voto ${ }^{407}$ ou excluídos dos efeitos da falência, valendo aqui as mesmas ponderações feitas no item precedente.

\footnotetext{
voto. As ações possuídas por esse acionista podem ser contabilizadas para a verificação da existência do quorum de instalação da assembleia (art. 125), mas não podem ser computadas para fins de apuração do quorum deliberativo" (Lei das Sociedades por Ações anotada... Op. cit., p. 317).

No mesmo sentido, mas salientando que a questão não é pacífica, assim leciona RICARDO TEPEDINO: "Computam-se as ações cujos titulares se achem impedidos de votar sobre a ordem do dia (v.g., os acionistas que ocupem cargos de administração numa AGO)? Valverde (loc. cit.), escrevendo sobre o artigo 90 da lei de 1940, de idêntica redação do atual artigo 125, julgava negativamente. Mas contrariando sua constância de acertos, parece ter errado: a lei impede o acionista de votar em certas questões, mas não exclui suas ações da verificação do quorum, que é aferido exclusivamente sobre as ações que em tese podem participar da votação (cf. Cunha Peixoto, loc. cit.)" (Direito das Companhias... Op. cit., p. 914).

${ }^{406}$ Recuperação judicial... Op. cit., 138.

${ }^{407}$ Vide os arts. $10, \S 2^{\circ}$, e 43 , caput e p.u., da LRF.
} 


\section{Presidência}

A Assembleia-Geral de Credores será presidida, em regra, pelo administrador judicial (LRF, art. 37, caput), exceto nas deliberações em que ele próprio for diretamente interessado, hipótese em que o conclave será presidido pelo credor presente titular do maior crédito ${ }^{408}$ (LRF, art. $37, \S 1^{\circ}$ ).

$\mathrm{O} \S 1^{\circ}$ do art. 36 também confere a presidência dos trabalhos ao maior credor na deliberação sobre o afastamento do administrador judicial, que seria justamente uma das hipóteses de incompatibilidade deste. Ocorre, todavia, que os dispositivos que conferiam à AGC competência para deliberar a substituição do administrador judicial (art. 35, I, "c" e II, "a") acabaram sendo vetados pelo Presidente da República ${ }^{409}$, de sorte que tal disposição restou esvaziada de sentido ${ }^{410}$.

Em regimes anteriores, como aqueles ditados pela Lei $\mathrm{n}^{\circ} 2.024 / 1908$ e pelo Decreto-Lei no 7.661/45, a Presidência da Assembleia-Geral de Credores competia ao juiz. JULIO KAHAN MANDEL ${ }^{411}$ defende que, mesmo atualmente, "nada impede que a assembléia seja realizada com a presença do promotor e do juiz, que poderá presidir a assembléia”. Para ele, “sem a presença mediadora do juiz, a assembléia pode-se tornar uma daquelas reuniões de condomínio onde ninguém se entende”.

A possível vantagem de se atribuir a presidência dos trabalhos ao juiz consistiria em diminuir os casos de invalidade da assembleia, pois as deliberações ilegais seriam por ele vetadas no próprio conclave, tal como expressamente previa o art. $122, \S 2^{\circ}$ do Decreto-Lei $n^{\circ}$ 7.661. Ainda assim, seria possível a anulação em recurso ou mesmo à vista de questão suscitada apenas depois da assembleia.

\footnotetext{
${ }^{408}$ Se o credor de maior crédito rejeitar a função, passa-se ao credor com o segundo maior crédito e assim por diante.

${ }^{409}$ Pelas razões explicitadas no item 4.1 deste Capítulo.

${ }^{410}$ Cf. SÉRgio CAMPInHo. Falência e recuperação de empresa... Op. cit., p. 80.

${ }^{411}$ Nova lei de falências... Op. cit., p. 83.
} 
Não se pode ignorar, ainda, que as funções da presidência demandam certa experiência e conhecimento técnico, próprias de uma justiça especializada, ainda muito longe de ser alcançada em termos nacionais.

De qualquer forma, segundo o regime vigente, não parece possível transferir ao juiz a presidência da AGC, por absoluta falta de amparo legal, conforme pondera JORGE $\mathrm{LOBO}^{412}$ : “o juiz e o órgão do Ministério público têm a prerrogativa de comparecer $e$ assistir aos trabalhos da assembleia geral, sem, entretanto, interferir ou influenciar nos debates e na votação”.

A lei não dispõe expressamente acerca das atribuições do presidente da AGC, mas permite inferir que lhe compete, entre outras funções, (i) verificar o atendimento do quórum de instalação do conclave (LRF, art. 37, § $2^{\circ}$ ), (ii) zelar pela identificação e legitimação dos credores participantes, que deverão assinar a lista de presença até a instalação da assembleia ${ }^{413}$ (LRF, art. 37, § $3^{\circ}$ ); e (iii) certificar-se acerca da regularidade da representação dos credores ${ }^{414}$ (LRF, art. $37, \S 4^{\circ}$ e $5^{\circ}$ ).

Compete ao presidente, em suma, dirigir os trabalhos e manter a ordem da assembleia, que se inicia pela declaração da sua instalação e leitura da ordem do dia ${ }^{415}$, passando-se à discussão e votação das matérias nela constantes e se encerra com a proclamação das deliberações e lavratura da ata ${ }^{416}$.

\footnotetext{
${ }^{412}$ In: Comentários... Op. cit., p. 155-156.

413 “Ao estabelecer o encerramento da coleta de assinaturas na lista de presença em concomitância com a abertura dos trabalhos, o legislador teve em mira proporcionar estabilidade à sua condução, evitando, inclusive, alterações profundas no quorum, que ocorreriam se recepcionados credores e/ou representantes até o momento das deliberações." (TJSP, Câm. Fal. e Recup., AI n ${ }^{\circ}$ 554.674-4/5-00, rel. Des. Araldo Telles, j. 25.6.2008).

${ }^{414}$ Notadamente daqueles credores representados por mandatários, representantes legais ou sindicatos (LRF, art. $37, \S \S 4^{\circ}$ e $\left.5^{\circ}\right)$.

415 “o administrador judicial colocará em discussão cada uma das matérias, objeto da assembleia, pela ordem e na sequência da enumeração constante da ordem do dia. Dará a palavra aos credores que dela quiserem fazer uso. Por deliberação da maioria absoluta dos presentes, poderá haver a inversão da ordem de deliberação das matérias constantes da ordem do dia, desde que justificadamente." (MODESTO CARVALHOSA. In: Comentários... Op. cit., p. 269).

${ }^{416}$ Cf. ERASMo VAlladẽo França. In: Comentários... Op. cit., p. 202.
} 
$\mathrm{Na}$ discussão e votação das matérias, compete ao presidente verificar a legitimação dos credores para o exercício dos direitos de voz e voto ${ }^{417}$, em estrita obediência $^{418}$ aos critérios legais e sobretudo às decisões judiciais proferidas ${ }^{419}$.

Cabe-lhe, ainda, disciplinar a forma do exercício desses direitos, devendo definir a ordem de votação, segundo o critério que eleger (valor do crédito, alfabético, assinatura na lista de presença etc) ${ }^{420}$.

Além disso, especialmente nas assembleias com muitos credores, convém ao presidente estabelecer o tempo máximo de manifestação de cada credor $^{421}$, sob pena de eternizar o conclave. Se ainda assim não for possível encerrar os trabalhos no mesmo dia, deverá designar data de continuação ${ }^{422}$.

Quanto à proclamação do resultado das deliberações, compete ao presidente computar os votos em estrita consonância com as regras ditadas na lei, observando o valor do crédito (segundo admitido à votação), a qualidade do credor e a matéria em votação, de modo que sejam respeitadas as instâncias deliberativas competentes e os quóruns exigidos para a aprovação.

\footnotetext{
${ }^{417}$ Vide item 8 deste Capítulo.

${ }^{418}$ Não se pode ignorar, porém que a função dos mesários (presidente e secretário) "caracteriza-se por uma atividade necessariamente discricionária, porque fundada em critérios opinativos, em procedimentos indutivos, em interpretações jurídicas e em elementos de experiência, nem sempre fixos e constantes" (Modesto Carvalhosa. In: Comentários à nova lei de falência... Op. cit., p. 269).

${ }^{419}$ Que tenham, p. ex., admitido a participação de credor que não tenha constado da relação de credores elaborada pelo administrador na forma do art. $7^{\circ}, \S 2^{\circ}$, da LRF ou do quadro-geral de credores.

${ }^{420}$ Cf. FÁBio UlhoA CoElho (Comentários... Op. cit., p. 133).

${ }^{421}$ A fim de evitar expedientes protelatórios, a Lei n 2.024/1908 previa que cada credor não poderia falar por mais de 10 minutos sobre o assunto em discussão, salvo com o consentimento do juiz, e depois de consultada a assembleia (art. 101, § $6^{\circ}$ ).

${ }^{422}$ Controverte-se sobre a necessidade de nova convocação em caso de adiamento da AGC. Acerca do tema, lembrando das divergências em torno da Lei das S.A., ERASMO VALLADÃo FranÇA pondera que, "em face das características de uma Assembléia-Geral de Credores, realizada na pendência de um processo de recuperação ou falimentar, cuja celeridade é determinada pela própria lei (parágrafo único do art. 75), tudo acrescido da circunstância de normalmente não se poder dispor de dinheiro suficiente para gastar em publicações, a solução teria que ser casuística. (...) Até seria recomendável que, prevendo tal possibilidade, em se tratando de uma Assembléia com numerosos credores, conste da própria convocação que, não sendo possível encerrar os trabalhos no mesmo dia, a Assembléia prosseguirá no dia subsequente ou daí a alguns dias. Conforme deliberar a própria Assembléia, independentemente de nova convocação" (In: Comentários: Op. cit., p. 204).
} 
Os protestos formulados pelos credores durante o conclave (a respeito, p. ex., da admissão do voto de determinado credor) deverão ser resolvidos, em regra, pelo presidente, sem prejuízo de ulterior revisão judicial, que poderá ensejar a proclamação de resultado diverso daquele anunciado na assembleia (se o protesto disser respeito à contagem de determinado voto), ou mesmo a invalidação completa do conclave (p.ex., em razão da instalação sem o quórum legal).

A competência do presidente para decidir os protestos se restringe às questões formais. Não lhe compete decidir protestos fundados na alegação de conflito de interesses ou de abuso de direito, devendo se limitar a anotá-los na ata. Haverá matérias, todavia, que se situarão numa "zona cinzenta", entre o formal e material, não sendo possível estabelecer uma linha rígida para separá-las. Nesses casos, deve-se contar com a experiência do administrador, valendo sempre lembrar que a validade do que porventura decidir ficará sujeita ao controle do juiz.

Para o exercício das suas funções, o presidente contará com o auxílio de um secretário $^{423}$ que designará entre os credores presentes, ao qual competirá a lavratura da ata $^{424}$ dos trabalhos, com o registro dos presentes, do resultado de cada uma das deliberações (e do voto de cada credor) e de quaisquer outros eventos relevantes ocorridos durante a assembleia, como eventual protesto apresentado por algum credor. Voltar-se-á a este tema no item 10 deste Capítulo.

\footnotetext{
${ }^{423}$ Cf. RONALDO ALVES DE ANDRADE, "a secretaria é um cargo extremamente importante, correspondente ao de escrivão nas audiências, na medida em que o secretário deverá elaborar uma ata da reunião, nela fazendo constar todas as ocorrências relevantes, inclusive no tocante à atuação do presidente." (In: DE LUCCA, Newton; e SIMÃO FILHO, Adalberto. Comentários à Nova Lei de Recuperação de Empresas e Falências. São Paulo: Quartier Latin, 2005, p. 185). No mesmo sentido leciona MODESTO CARVALHOSA: "a presença do secretário da mesa é imprescindível à instalação e realização da assembleia geral de credores. Nesse sentido, caberá ao secretário da mesa auxiliar o presidente nos trabalhos de instalação, realização e conclusão do conclave. Compete-lhe lavrar a ata que constitui a sua principal função" (In: Comentários à nova lei de falência... Op. cit., p. 268).

${ }^{424}$ Essa ata deverá ser entregue ao juiz, juntamente com a lista de presença, no prazo de 48 (quarenta e oito) horas contado do encerramento da assembleia (LRF, art. 37, $\S 7^{\circ}$ ).
} 


\section{A participação dos credores na Assembleia}

\subsection{Lista de presença}

Requisito formal para que o credor seja admitido a participar $^{425}$ da AGC consiste na assinatura da lista de presença (LRF, art. $\left.37, \S 3^{\circ}\right)^{426}$. Só poderão assiná-la, todavia, os credores legitimados para participar do conclave e que estejam regularmente representados (quando for o caso de representação).

Compete à mesa da Assembleia fazer essa verificação antes de permitir qualquer assentamento na lista ${ }^{427}$, certificando-se acerca da legitimidade ${ }^{428}$ do credor para participar do conclave e da regularidade da sua representação, observado o disposto nos parágrafos $4^{\circ}$ a $6^{\circ}$ do art. 37 da LRF, comentados a seguir ${ }^{429}$.

A lista de presença deve ser preenchida com o nome do credor, a espécie e o valor do seu crédito $^{430}$, com a devida identificação da classe deliberativa que integra (quando a deliberação ou alguma delas não for de competência do plenário).

A partir dessas anotações serão verificados os quóruns de instalação e de deliberação da assembleia ${ }^{431}$.

\footnotetext{
${ }^{425}$ O verbo "participar" abrange o exercício dos direitos de voz e de voto.

${ }^{426}$ Art. 37. $\S 3^{\circ}$ Para participar da assembléia, cada credor deverá assinar a lista de presença, que será encerrada no momento da instalação.

427 "O lançamento das presenças em lista está condicionado ao preenchimento de outro requisito preliminar à instalação da assembleia, qual seja, a prova de legitimação para o comparecimento ao conclave, na qualidade de credor ou seu representante (LFR, art. 37, $\S 4^{\circ}$ ). Assim é que, antes de qualquer assentamento, deverá ser positivado pela mesa o cumprimento desse requisito de legitimação e representação" (MODESTO CARVAlHOSA. In: Comentários à nova lei de falência... Op. cit., p. 271).

${ }^{428}$ A legitimidade do credor será aferida conforme o art. 39 da LRF (explicado em detalhes nos itens 2.1 e 2.2 deste Capítulo) e em respeito às regras que excluem certos credores do AGC.

${ }^{429}$ Vide itens 8.2.1 a 8.2.3, a seguir.

${ }^{430}$ Já se decidiu que, à falta de norma específica sobre o assunto, basta que o credor assine a lista de presença apenas uma vez, não se podendo exigir que lance a sua assinatura à frente de cada crédito (TJSP, Câm. Fal. e Recup., AI $n^{\circ}$ 554.674-4/5-00, Rel. Des. Araldo da Costa Telles, j. 25.6.2008). Discorda-se, no entanto, do fundamento adotado no acordão, consubstanciado no parecer da Promotora de Justiça oficiante, no sentido de que a assinatura da lista de presença "visa unicamente não permitir tumulto com ingresso de outros não identificados, após a instalação da assembléia". Na verdade, a principal finalidade da lista é permitir a verificação do atendimento dos quóruns de instalação e de deliberação. Assim, não é desarrazoado exigir que, sendo titular de dois ou mais créditos de natureza distinta, o credor faça a anotação de ambos separadamente, devendo a mesa zelar para que seja tomado esse cuidado.
} 
A lista de presença será encerrada no momento em que o presidente declarar instalado o conclave (LRF, art. 37, $\S 3^{\circ}$, in fine). A partir de então, ainda que compareçam outros credores, eles não mais serão admitidos a participar do conclave, isto é, não poderão votar nem debater as matérias da ordem do dia $^{432}$.

Tal determinação é relevante para conferir estabilidade e segurança jurídica às deliberações $^{433}$, a fỉm de evitar a alteração da base de cálculo dos quóruns deliberativos durante a realização da assembleia, o que resultaria em verdadeiro caos:

\begin{abstract}
"Ao estabelecer o encerramento da coleta de assinaturas na lista de presença em concomitância com a abertura dos trabalhos, o legislador teve em mira proporcionar estabilidade à sua condução, evitando, inclusive, alterações profundas no quorum, que ocorreriam se recepcionados credores e/ou representantes até o momento das deliberações." 434
\end{abstract}

Não se vê óbice a que os credores atrasados ingressem e permaneçam no recinto onde se realiza a $\mathrm{AGC}$, desde que fiquem em silêncio ${ }^{435}$. A questão, contudo, não é pacífica, ensejando interpretações radicalmente opostas.

Erasmo Valladẽo FranÇA ${ }^{436}$ e Nelson Rodrigues Neto $^{437}$ defendem que, depois de instalada a assembleia, não deverá ser permitido o ingresso de mais nenhum credor.

${ }^{431}$ Como alguns credores são admitidos a participar do conclave apenas com direito de voz, sem importância para os quóruns de instalação e deliberação, seria conveniente desmembrar a lista de presença em duas: a primeira a ser assinada pelos credores com direito de voto e a segunda para esses outros credores.

${ }^{432}$ Para RonALDo Alves DE ANDRADE, decorre do art. 37, $\S 3^{\circ}$, da LRF que "somente poderão votar os credores que tiverem assinado a lista até o momento da instalação da assembléia, estando, portanto, inabilitados para votar os credores que chegarem atrasados à assembléia" (In: DE LUCCA, Newton [et. al.]. Comentários à nova lei de recuperação de empresas... Op. cit., p. 186)

433 "A lista de presença deve ser encerrada, no exato momento em que for dado início aos trabalhos, não se admitindo o ingresso retardatário de nenhum credor. Isso é imprescindível para conferir segurança jurídica aos trabalhos que serão desenvolvidos e à composição, pelo voto, da maioria. Se depois de encerrada a lista de presença, fosse admissível o ingresso de outros credores, a base de cálculo para os quóruns e o próprio resultado das votações poderiam ser alterados." (FÁBIO UlHOA COELHO. Comentários à lei de falências... Op. cit., p. 132).

${ }^{434}$ TJSP, Câm. Fal. e Recup., AI no 554.674-4/5-00, Rel. Des. Araldo da Costa Telles, j. 25.6.2008, citado por CRISTIANO IMHOF (Lei de recuperação de empresas e falência... Op. cit., p. 18).

${ }^{435}$ Caso os credores atrasados provoquem algum tumulto, deverá o presidente da AGC, a quem compete manter a ordem dos trabalhos, providenciar para que eles sejam retirados do recinto. 
Já MARIO SÉRGIO MILANI ${ }^{438}$ afirma que “o credor que não a assinou poderá permanecer no conclave, mas não terá o direito de votar.". Nesse mesmo sentido é a opinião de GLADSTON MAMEDE ${ }^{439}$.

O segundo entendimento parece mais acertado porque a regra que impede a "participação" dos credores depois do encerramento da lista, por ser limitadora de direitos, deve ser interpretada restritivamente ${ }^{440}$. Assim, só deverá cercear o exercício ativo dos direitos de que gozam os credores durante assembleia, isto é, o voto, a voz e o protesto. Não haverá de limitar, portanto, o comportamento passivo do credor, de mera contemplação dos debates e das deliberações, até porque não se vislumbra prejuízo em razão da mera presença de alguém que teria legitimidade para tomar parte da AGC. Logicamente, a admissão do credor nesse caso não terá o condão de alterar o quórum deliberativo fixado por ocasião da abertura da assembleia. ${ }^{441}$

Encerrados os trabalhos, a lista de presença deverá ser encaminhada ao juiz, no prazo de quarenta e oito horas, juntamente com a ata da assembleia (LRF, art. 37, § $7^{\circ}$ ).

436 “...declarada a instalação da Assembléia, nenhum credor poderá mais entrar no recinto, devendo ser encerrada a lista de presença. Do contrário, a todo o momento teria de ser novamente verificado o quórum de deliberação" (In: SOUZA JÚNIOR, Francisco Satiro de. Comentários... Op. cit., p. 205).

437 "Não é permitido o ingresso à assembléia após encerrada a lista de presença" (Comentários à lei de recuperação judicial... Op. cit., p. 83).

${ }^{438}$ Lei de recuperação judicial... Op. cit., p. 178.

439 "Para participar da assembléia, cada credor deverá assinar a lista de presença, que será encerrada no momento da instalação; aqueles que chegarem após o encerramento da lista e concomitante ao início dos trabalhos, embora possam assistir aos trabalhos, não se considerarão participantes, ou seja, não terão direito de votar, nem poderão exercer as faculdades que lhes sejam conexas, como o debate do mérito das questões." (Falência e recuperação de empresas. 3 ed. São Paulo: Atlas, 2009, p. 226).

${ }^{440}$ No âmbito das sociedades anônimas, em que não existe norma semelhante ao art. $37, \S 3$, MODESTO CARVALHOSA sustenta que "nada impede que os acionistas retardatários sejam admitidos à assembléia, nela podendo exercer todos os direitos inerentes às respectivas ações, inclusive o de votar. Seus nomes não constarão do Livro de Presença, mas, sim, da ata da assembléia" (Comentários à Lei de Sociedades Anônimas... Op. cit., v. 2, p. 127-128). DARCY ARRUDA MIRANDA JR. também admite a presença dos acionistas retardatários, que aporão seus nomes após o termo de encerramento da assembleia, mas silencia quanto à possibilidade de exercerem os direitos de voz ou voto (Breves comentários à lei de sociedades por ações. São Paulo: Saraiva, 1977, p. 185).

${ }^{441}$ Discorda-se, com a devida vênia, do Prof. ERASMO VALLADÃo FRANÇA por não se vislumbrar relação entre a mera admissão no recinto do credor atrasado e o quórum deliberativo. Não há incompatibilidade entre a manutenção deste a despeito da chegada intempestiva daquele, uma vez que privado do direito de voto. 


\subsection{Representação}

Para participar da AGC, o credor deverá comparecer pessoalmente, ou se fazer representar. Desde que respeitadas algumas formalidades, os credores poderão ser representados por mandatário, pelo seu representante legal ou, ainda, em se tratando de titulares de créditos derivados da legislação do trabalho ou decorrentes de acidente do trabalho, por sindicato de trabalhadores ao qual sejam filiados.

\subsubsection{Pelo mandatário}

O credor poderá ser representado na AGC por mandatário. Para tanto, o credor deverá, até vinte e quatro horas antes da assembleia ${ }^{442}$, entregar ao administrador judicial documento hábil para comprovar os poderes do seu mandatário, ou indicar as folhas dos autos em que se encontra tal documento ${ }^{443}$ (LRF, art. $\left.37, \S 4^{\circ}\right)^{444}$. Isto é, deverá encaminhar ao administrador judicial o instrumento de procuração ou então, se já encartado nos autos, comunicá-lo em que folha está.

Como a lei se refere a “documento", pressupõe-se que o mandato deverá adotar a forma escrita ${ }^{445}$, mas não há exigência de instrumento público. O instrumento de mandato deverá conferir poderes especiais ${ }^{446}$ para que o mandatário possa participar da

\footnotetext{
${ }^{442}$ Para ADAlberto Simão FiLHo, no caso de o documento de representação já se achar nos autos, a falta de comunicação da folha dos autos em que se encontra não deverá impedir o credor de participar da assembleia, eis que se cuida de irregularidade facilmente suprível. ("Interesses transindividuais dos credores nas Assembléias-Gerais e sistemas de aprovação do plano de recuperação judicial”. Op. cit., p. 44).

443 Já se decidiu que essa obrigação (de previamente entregar ou indicar nos autos o documento de representação) se aplica apenas à primeira AGC realizada, eis que os demais conclaves seriam mera continuação (TJSP, Câm. Fal. e Recup., MS nº 553.556-4/3-00, rel. Des. Pereira Calças, j. 28.5.2008). Ainda nesse sentido, FÁBIO UlHOA COELHO afirma que "feita a comunicação com antecedência legal em relação à primeira convocação, não é necessário que ela se repita também na segunda. Como se trata da mesma Assembleia, deve-se considerar que o administrador judicial está ciente da outorga da procuração" (Comentários... Op. cit., p. 135).

${ }^{444}$ Art. $37, \S 4^{\circ}$. O credor poderá ser representado na assembléia-geral por mandatário ou representante legal, desde que entregue ao administrador judicial, até 24 (vinte e quatro) horas antes da data prevista no aviso de convocação, documento hábil que comprove seus poderes ou a indicação das folhas dos autos do processo em que se encontre o documento.

445 "resta descartado, in totum, o mandato verbal" (MARIO SERGIO MiLANI. Lei de Recuperação Judicial... Op. cit., p. 178).

446 Cf. José da Silva PACHeCo. Processo de recuperação judicial, extrajudicial e falência. 3. ed. Rio de Janeiro: Forense, 2009, p. 122.
} 
assembleia $^{447}$, vez que as deliberações nela tomadas exorbitam os atos de mera administração (Código Civil, art. 661, $\S 1^{\circ}$ ), bem como as prerrogativas da cláusula $a d$ judicia $^{448}$ (CPC, art. 38, caput $)^{449}$. Por outro lado, também poderá especificar (e restringir) as matérias da ordem do dia que poderão ser objeto de manifestação e deliberação pelo mandatário $^{450}$.

Caso a procuração seja outorgada por instrumento particular, poderá ser exigido pelo administrador judicial ou por qualquer credor que do documento conste a autenticação da firma do mandante por notário (Código Civil, art. 654, § $\left.2^{\circ}\right)^{451}$.

Não sendo feita tal exigência, a falta da autenticação não ensejará a invalidade ou ineficácia do instrumento ${ }^{452}$. Advogados constituídos para atuar no processo por procuração geral para o foro (mas que também confira poderes especiais para representação do constituinte na assembleia) estão dispensados de apresentar firma reconhecida, conforme estabelece o art. 38 do Código de Processo Civil, com a redação que lhe deu a Lei $n^{\circ} 8.952 / 94 .{ }^{453}$

\footnotetext{
${ }^{447}$ Segundo JORGE LOBO, o mandato deverá conferir "poderes especiais e expressos para votar, acordando, discordando, transigindo, firmando compromisso, renunciando a direitos e privilégios, ou quaisquer outros atos que exorbitem da administração ordinária (CC, arts. 653 e 661, § 1º)" (In: Comentários à lei de recuperação... Op. cit., p. 149).

${ }^{448}$ Art. 661. O mandato em termos gerais só confere poderes de administração.

$\S 1^{\circ}$. Para alienar, hipotecar, transigir, ou praticar outros quaisquer atos que exorbitem da administração ordinária, depende a procuração de poderes especiais e expressos.

${ }^{449}$ Art. 38. A procuração geral para o foro, conferida por instrumento público, ou particular assinado pela parte, habilita o advogado a praticar todos os atos do processo, salvo para receber citação inicial, confessar, reconhecer a procedência do pedido, transigir, desistir, renunciar ao direito sobre que se funda a ação, receber, dar quitação e firmar compromisso.

${ }^{450}$ Cf. Modesto CaRvalhosa. In: Comentários à nova Lei de Falência e Recuperação de Empresas... Op. cit., p. 273.

${ }^{451}$ Art. $654, \S 2^{\circ}$. O terceiro com quem o mandatário tratar poderá exigir que a procuração traga a firma reconhecida.

${ }^{452}$ Diferentemente do que havia no regime do Código Civil de 1916, em que o reconhecimento de firma era condição de validade do mandato perante terceiros: "Nos termos do revogado $\S 3^{\circ}$ do art. 1.289 do Código Civil de 1916, o reconhecimento de firma, no instrumento particular, consistia em condição essencial à sua validade em relação a terceiros. (...) No sistema atual, o $\S 2^{\circ}$ mitiga a antiga exigência formal, ao estabelecer que o terceiro interessado poderá exigir que a procuração traga firma reconhecida" (GUSTAVO TEPEDINO. Comentários ao Novo Código Civil. Coleção coordenada por Sálvio de Figueiredo Teixeira. Rio de Janeiro: Forense, 2008. v. 10, p. 53-54). Por isso, é impreciso dizer que o reconhecimento de firma será sempre obrigatório (como faz JORGE LOBO. In: Comentários... Op. cit., p. 149), bem como afirmar que tal reconhecimento será sempre dispensável (como sustenta MODESTO CARVALHOSA. In: Comentários à nova lei de falência... Op. cit., p. 273).

${ }^{453} \mathrm{O}$ art. 38 do CPC, com a redação dada pela Lei $\mathrm{n}^{\circ} 5.925 / 73$, exigia que a procuração outorgada ao advogado por instrumento particular tivesse firma reconhecida. A Lei no 8.952/94 acabou com essa exigência.
} 
A par das hipóteses de revogação por fatos naturais ou pela perda da capacidade das partes, o credor poderá revogar o mandato tanto tacitamente (caso ele próprio compareça à assembleia e dela tome parte) quanto expressamente, mediante notificação ao mandatário da revogação do mandato ou da constituição de novo procurador (Código Civil, art. 687) ${ }^{454}$. Caso o próprio mandante não compareça à assembleia, cumprelhe informar a revogação do mandato ao administrador judicial antes da realização do conclave, sob pena de se reputar eficaz a participação do mandatário (Código Civil, art. 686 , caput $)^{455}$.

\subsubsection{Pelo representante legal}

As mesmas exigências à representação por mandatário são feitas em relação ao representante legal, que também deverá encaminhar ao administrador judicial prova documental da representação ou comunicar a folha em que se acha nos autos, sempre no prazo de até vinte e quatro horas antes da assembleia (LRF, art. 37, § $4^{\circ}$ ).

\subsubsection{Hipóteses de efetiva representação legal}

A representação, como se sabe, poderá ser legal ou voluntária $\left(\mathrm{CC}\right.$, art. 115) ${ }^{456}$. Diz-se voluntária aquela derivada de convenção das partes, que se aperfeiçoa por meio de procuração. Aqui, os poderes do representante não resultam (diretamente) da lei, mas são determinados pelo representado, que os pode fixar na extensão que entender conveniente $^{457}$. Dessa espécie já se cuidou no item precedente.

Desde então, passou a haver controvérsia jurisprudencial acerca da extensão da dispensa à procuração que, além de conferir poderes gerais para o foro, também outorgasse poderes especiais. Atualmente, tem prevalecido o entendimento de que a dispensa do reconhecimento de firma se aplica à procuração ad judicia et extra utilizada nos autos de processo judicial (STJ, $2^{\mathrm{a}}$ T., REsp. 716.824-AL, Rel. Min. Eliana Calmon, j. 11.4.2006 e STJ, Corte Especial, REsp no 256.098, Rel. Min. Sálvio de Figueiredo Teixeira, DJ de 7.12.2001), mas ainda existe muita controvérsia sobre o tema, inclusive no âmbito do STJ (vide REsp. $\mathrm{n}^{\mathrm{o}}$ 616.435, $5^{\mathrm{a}}$ T., rel. Min. José Arnaldo da Fonseca, j. 4.8.2005). Assim, para evitar risco, é prudente que o mandatário sempre apresente procuração com firma reconhecida, ainda que se trate de advogado.

454 Art. 687. Tanto que for comunicada ao mandatário a nomeação de outro, para o mesmo negócio, considerar-se-á revogado o mandato anterior.

${ }^{455}$ Art. 686. A revogação do mandato, notificada somente ao mandatário, não se pode opor aos terceiros que, ignorando-a, de boa-fé com ele trataram; mas ficam salvas ao constituinte as ações que no caso lhe possam caber contra o procurador.

${ }^{456}$ Art. 115 . Os poderes de representação conferem-se por lei ou pelo interessado.

457 Cf. Eduardo Ribeiro de OliveIRA. Comentários ao Novo Código Civil. 2 ed. Coleção coordenada por Sálvio de Figueiredo Teixeira. Rio de Janeiro: Forense, v. 2, p. 276. 
A representação legal, por sua vez, é aquela que decorre diretamente da lei e é exercida nos exatos limites nela estabelecidos. Aplica-se, ordinariamente, àqueles reputados incapazes para os atos da vida civil, como os menores de dezesseis anos, as pessoas privadas de discernimento por enfermidade ou deficiência mental e os que, mesmo por causa transitória, não puderem exprimir sua vontade $\left(\mathrm{CC}, \operatorname{art.} 3^{\circ}\right)$.

Essas pessoas serão representadas, conforme o caso, por seus pais, tutores ou curadores nomeados pelo juiz. Assim, p. ex., um empregado do devedor que tenha sofrido processo de interdição será legalmente representado pelo seu curador (CC, art. 1.767), da mesma forma que um menor impúbere que tenha recebido o crédito por sucessão será legalmente representado por seus pais ou pelo tutor nomeado pelo juiz $(\mathrm{CC}$, arts. 1.634, V e 1.728).

A representação legal não se limita, porém, aos casos de incapacidade. Entre outras hipóteses, também se aplica ao ausente, representado pelo curador (CC, art. 22), ao condomínio, representado pelo síndico (CC, art. 1.348, II), à sociedade em liquidação, representada pelo liquidante (CC, art. 1.122), à massa falida, representada pelo administrador judicial ou pelo síndico ${ }^{458}$ (LRF, art. 22, III e DL 7.661/45, art. 63), e até a empresa em recuperação judicial, que poderá ser representada por um gestor judicial (LRF, art. 65).

Note-se que a representação legal costuma se sujeitar a algumas restrições. Há certos atos que são vedados a tutores e curadores, enquanto outros dependem de autorização judicial (CC, arts. 1.748, 1.749 e 1.774). Entre estes que demandam autorização, destaca-se a transação (CC, art. 1.748, III), pelo que se conclui que o voto proferido pelo tutor ou curador na AGC, dependendo do teor, tem sua eficácia condicionada à aprovação do juiz (CC, art. 1.748, p. u.).

O mesmo vale, p. ex., para o administrador judicial que representa a massa falida na AGC de outra empresa. Aqui também a transação dependerá de autorização judicial, exigindo-se ainda que sejam ouvidos o Comitê de Credores e o próprio devedor (LRF, art. $22, \S 3^{\circ}$ ).

\footnotetext{
${ }^{458}$ A figura do síndico ainda existe porque os processos de falência ajuizados anteriormente ao início da vigência da Lei nº 11.101/2005 serão concluídos nos termos do Decreto-Lei no 7.661/1945 (LRF, art. 192).
} 
Por isso, antes de admitir a participação do representante legal na assembleia, especialmente nas deliberações tomadas, caberá ao administrador judicial, enquanto presidente do conclave, certificar-se acerca dos poderes que possui, devendo impedir o voto daquele que não estiver autorizado a fazê-lo, a fim de resguardar a validade e eficácia das deliberações tomadas ${ }^{459}$.

\subsubsection{A “representação" da sociedade por seus administradores}

Parte da doutrina e da jurisprudência tem dado intepretação estrita ${ }^{460}$ à expressão representante legal constante do art. 37, $\S 4^{\circ}$, da LRF, para nela compreender apenas os casos de efetiva "representação", na acepção mais técnica do termo.

Defendem, em síntese, que a exigência de prévio encaminhamento ou indicação dos documentos de representação não se aplicaria ao administrador da sociedade credora, que enquanto órgão da sociedade não seria propriamente o seu representante legal, mas o seu presentante. Funda-se tal intelecção na lição clássica de PONTES DE MIRANDA ${ }^{461}$, segundo a qual, "quando o órgão da pessoa jurídica pratica o ato, que há de entrar no mundo jurídico como ato da pessoa jurídica, não há representação, mas presentação. $\mathrm{O}$ ato do órgão não entra, no mundo jurídico, como ato da pessoa, que é o órgão (...) Entra como ato da pessoa jurídica, porque o ato do órgão é ato seu."

Invocando as lições de FÁBIO UlHOA COELhO ${ }^{462}$, assim decidiu o Tribunal de Justiça de São Paulo:

"Agravo de instrumento. Recuperação Judicial. Assembléia de Credores. Sociedade presentada por seu administrador. Teoria organicista. O Administrador é órgão social e, por isso, não representa a sociedade. Inaplicabilidade da exigência do artigo 37 , parágrafo $4^{\circ}$,

\footnotetext{
${ }^{459}$ Eventuais protestos formulados em decorrência de o representante legal ser impedido de participar do conclave ou de votar certas matérias deverão ser solucionados pelo juiz.

${ }^{460} \mathrm{Ou}$ interpretação especificadora, como prefere TERCIO SAMPAIO FERRAZ JR., consistente na interpretação que "parte do pressuposto de que o sentido da norma cabe na letra do seu enunciado" (p. 293).

${ }^{461}$ Tratado de Direito Privado. 2 ed. Rio de Janeiro: Borsoi, 1954, t. 3, p. 233.

462 "A lei fala, no parágrafo $4^{\circ}$, que a formalidade e antecedência nele indicadas para o procurador também se exigem do 'representante legal'. Deve-se entender essa expressão no seu sentido técnico específico delineado no Código Civil (arts. 115 a 120). Quero dizer, o preceito não é aplicável aos presentantes das pessoas jurídicas, isto é, seus diretores e administradores" (Comentários à lei de falências... Op. cit., p. 136).
} 
da LRF, ao presentante legal da sociedade credora. O administrador de sociedade empresária não é considerado seu representante legal, mas sim, seu presentante, razão pela qual, não precisa cumprir a formalidade prevista no artigo 37, parágrafo $4^{\circ}$, da LRF, para poder ser admitido e participar, com direito de voz e voto, da Assembléia de Credores na Recuperação Judicial. Agravo provido." ${ }^{463}$

Com a devida vênia, a expressão "representante legal" constante do art. 37, § $4^{\circ}$, da LRF não deve ser interpretada com tal rigorismo técnico, até porque, conforme assinala CARVALHO DE MENDONÇA ${ }^{464}$, “nem sempre se pode exigir em uma lei correção absoluta de linguagem". A ratio da norma em questão é eminentemente prática, destinando-se a evitar que, na hora da assembleia, o presidente do conclave perca tempo para examinar se a pessoa natural que ali comparece para votar tem realmente poderes para fazê-1o ${ }^{465}$. É por isso que se exige que os documentos de legitimação sejam encaminhados ou indicados com antecedência.

Não faz nenhuma diferença, do ponto de vista prático, se esses documentos consistem na procuração outorgada ao advogado, no termo de curadoria, ou no contrato ou ata assemblear que elegeu o administrador da sociedade ${ }^{466}$. Em todos os casos, demandarse-á algum tempo para que os poderes sejam verificados. E foi para não tumultuar o início dos trabalhos, especialmente nas assembleias com muitos credores, que a lei exigiu a apresentação prévia de tais documentos ${ }^{467}$.

\footnotetext{
${ }^{463}$ Câm. Fal. e Recup., AI n ${ }^{\circ}$ 429.581-4/3-00, rel. Des. Pereira Calças, j. 15.3.2006. Nesse mesmo sentido, confira-se, da mesma câmara e relator, o AI no 990.10.183666-1, j. 19.10.2010.

${ }^{464}$ Tratado de Direito Comercial Brasileiro. 5 ed. Rio de Janeiro: Freitas Bastos, 1954. v. 7, p. 373.

${ }^{465}$ A verificação, na hora do conclave, deve se limitar à identidade física das pessoas que ali comparecem, mas a verificação dos seus poderes deve ser feita antes, justamente para evitar tumulto e perda de tempo.

466 “... para comprovação da qualidade de representante legal de credor pessoa jurídica, exige-se a apresentação do estatuto ou contrato social, juntamente com a ata da assembleia ou reunião do conselho de administração da sociedade anônima, ou reunião de sócios da limitada, na qual foi eleito o representante." (Modesto CARVAlHosa. In: Comentários à nova lei de falência... Op. cit. p. 274).

${ }^{467}$ Nesse sentido, defendendo que o art. $37, \S 4^{\circ}$, também se aplica aos administradores da empresa, assim se manifesta ERASMO VALLADÃo FRANÇA: "O representante legal das pessoas jurídicas, no dizer expressivo de Pontes de Miranda, presenta a pessoa jurídica, Esta se faz presente, nos atos jurídicos, pelo seu órgão de administração. Não obstante essa distinção, há de se atender aqui à intenção da lei ao estabelecer o aludido prazo mínimo de 24 horas anteriores à Assembléia, que nos parece perfeitamente clara: evitar que o administrador judicial, no dia do conclave, fique a conferir, antes da assinatura da lista de presença, contratos sociais, atas de assembléias, atas de conselhos de administração, estatutos de associações e fundações etc. etc., para verificar se o indivíduo que ali comparece tem poderes para presentar a pessoa jurídica credora... De modo que, a nosso ver, a exigência contida nesse parágrafo se aplica igualmente ao representante legal das pessoas jurídicas." (In: Comentários à lei de recuperação de empresas... Op. cit., p. 205-206).
} 
Além disso, embora seja correto afirmar, do ponto de vista técnico, que o administrador da sociedade não é seu representante legal, não se pode desconsiderar que as leis frequentemente lhe dispensam esse tratamento, a começar pelo próprio Código Civil, cujo art. 46, inc. III, estabelece que o registro da pessoa jurídica declarará "o modo por que se administra e representa, ativa e passivamente, judicial e extrajudicialmente" ${ }^{468}$.

O Decreto $n^{\circ} 7.661 / 45$ é abundante em tais referências, a começar pelo seu art. 32, inc. I, que dispunha expressamente: "são considerados representantes dos credores na falência... os administradores, gerentes ou liquidantes das sociedades e prepostos com poderes de administração geral". Os administradores da sociedade são ainda referidos como seus representantes nos artigos $2^{\circ}, 11,13,14$ e 37 , entre outros do mesmo diploma.

O Código de Processo Civil também menciona o "representante legal da pessoa jurídica" querendo se referir, inclusive, ao administrador da sociedade (art. 29, $2^{\circ}$, III), assim como faz a Lei dos Registros Públicos (Lei nº 6.015/73), que em seu art. 121 estabelece que o registro da pessoa jurídica deverá ser requerido mediante petição do "representante legal da sociedade".

São apenas alguns dos inúmeros exemplos que poderiam ser citados, a ensejar, mediante interpretação sistemática, a conclusão de que, ao se referir aos "representantes legais", o art. $37, \S 4^{\circ}$, da LRF não excluiu os administradores da sociedade do dever de apresentar previamente os documentos que comprovam seus poderes.

De mais a mais, vale lembrar que o art. 1.011, $\S 2^{\circ}$, do Código Civil dispõe que se aplicam às atividades dos administradores, no que couber, as normas relativas ao mandato, o que confirma que o ordenamento jurídico aproxima as figuras do representante e do presentante, parecendo assim injustificável, por todas essas razões, estabelecer distinção entre eles para fins de aplicação do art. 37, $\S 4^{\circ}$, da LRF.

\footnotetext{
468 "O Código de 1916, em seu artigo 17, estabelecia que as pessoas jurídicas seriam representadas por quem os respectivos estatutos designassem, e, à falta, por seus diretores. Caio Mário observa que o novo diploma 'substituiu a expressão inadequada (representantes) pela correta menção aos 'órgãos' de deliberação e execução da pessoa jurídica (e.g., art. 54)'. Se isso é verdade, não menos exato, entretanto, que, ao tratar do registro da pessoa jurídica, em seu artigo 46, estabeleceu que esse conteria 'o modo por que se administra e representa, ativa e passivamente, judicial e extrajudicialmente'." (EDUARDO RIBEIRO DE OLIVEIRA. Comentários ao Novo Código Civil... Op. cit., p. 263-264; destacou-se).
} 


\subsubsection{Pelo sindicato de trabalhadores}

Admite-se, ainda, que os titulares de créditos derivados da legislação do trabalho ou decorrentes de acidente do trabalho, caso não se façam presentes na assembleia pessoalmente ou por procurador, sejam representados pelo sindicato de trabalhadores ao qual sejam filiados (LRF, art. $\left.37, \S 5^{\circ}\right)$.

Esta representação se faz, portanto, em caráter meramente supletivo ${ }^{469}$, para o caso de o trabalhador não comparecer nem constituir procurador, o que é coisa muito comum no dia-a-dia das assembleias ${ }^{470}$, notadamente em razão da simplicidade e das poucas condições dessa espécie de credor.

Além disso, note-se que a legitimidade do sindicato se restringe, por expressa disposição legal, apenas aos seus associados. Para representá-los, caso não compareçam à AGC nem constituam procurador, basta a prova da filiação, não sendo necessária autorização expressa do associado. Presume-se haver uma espécie de delegação tácita decorrente do ato associativo, que autoriza a representação pelo sindicato.

Contudo, em que pese a prerrogativa constitucional de "defesa" dos direitos da categoria $\left(\mathrm{CF} \text {, art. } 8^{\circ}, \S 3^{\circ}\right)^{471}$, não cabe ao sindicato representar na AGC os trabalhadores que não se filiaram aos seus quadros.

Conquanto se admita o ingresso do sindicato nos autos, na qualidade de substituto processual, para a defesa dos direitos coletivos ou individuais homogêneos de toda categoria ${ }^{472}$, isso não lhe permite manifestar vontade em nome de quem não o

\footnotetext{
${ }^{469}$ Cf. ADALBERTO SimÃo FiLHO. "Interesses transindividuais dos credores...”. Op. cit., p. 45.

${ }^{470}$ Nesse sentido, confira-se RONALDO ALVES DE ANDRADE: "a medida é adequada e outorga ao trabalhador a oportunidade de ter voz na assembléia, uma vez que em geral o trabalhador não está afeito a essas questões e, na maior parte das vezes não pode comparecer pessoalmente ou por procurador" (In: Comentários à nova lei de recuperação de empresas... Op. cit., p. 187).

${ }^{471}$ Art. $8^{\circ}$. É livre a associação profissional ou sindical, observado o seguinte: (...) III - ao sindicato cabe a defesa dos direitos e interesses coletivos ou individuais da categoria, inclusive em questões judiciais ou administrativas.

${ }^{472}$ Enquanto substituto processual, o sindicato tem legitimidade, independentemente de autorização expressa, para defender os interesses de toda categoria, não apenas de seus filiados. Nesse sentido se firmou a jurisprudência do STJ: "o sindicato ou associação, como substitutos processuais, têm legitimidade para defender judicialmente interesses coletivos de toda a categoria, e não apenas de seus filiados, sendo dispensável a juntada da relação nominal dos filiados e de autorização expressa" (AgRg no Ag no 1153516GO. $6^{a}$ Turma, Rel. Min. Maria Thereza de Assis Moura, 4.11.2009).
} 
autorizou a fazê-lo (nem mesmo tacitamente, por via de adesão). A defesa de direito e a manifestação de vontade são coisas distintas, não sendo dado ao sindicato, sem que esteja autorizado a tanto, transigir acerca do direito individual (já adquirido) de trabalhador com o qual não mantém relação ${ }^{473}$.

Não há incompatibilidade alguma, portanto, entre o art. $8^{\circ}$, III, da Constituição Federal e art. $37, \S 5^{\circ}$, da LRF, que não comporta interpretação extensiva, como bem pondera JORGE LOBO $^{474}$ :

"se, no caso de normas com várias significações possíveis, o juiz deve encontrar a significação que aparente conformidade com a Constituição, a norma do parágrafo $5^{\circ}$ do artigo 37 da nova Lei de Falências se adequa e é perfeitamente compatível com a do inciso III do artigo $8^{\circ}$ da Carta, apenas lhe reduzindo o campo de aplicação, por força da especificidade e relevância da matéria, que está longe de ser a simples e rotineira defesa de certa categoria em uma convenção coletiva de trabalho ou em uma ação coletiva como substituto processual, mas a participação no intrincado e complexo processo de recuperação judicial de empresas em estado de crise econômicofinanceira".

Para exercer a prerrogativa prevista art. $37, \S 5^{\circ}$, da LRF, o sindicato deverá apresentar ao administrador judicial, até dez dias antes da assembleia, a relação dos associados que pretende representar.

Nesse mesmo sentido, admitindo a condição de substituto processual do sindicato, assim decidiu o Tribunal de Justiça do Rio de Janeiro: "O art. $8^{\circ}$, III, da CRFB/88, garante aos sindicatos legitimidade para defender direitos interesses coletivos ou individuais da categoria. Recuperação judicial de sociedade empresária que gera aos seus funcionários direito individual homogêneo, decorrente da mesma origem, a recuperação judicial. Possibilidade de ingresso do sindicato da classe no feito, na qualidade de substituto processual, em razão da sua legitimidade extraordinária. Não é o caso de aplicação do art. $37, \S 5^{\circ}$, da Lei Falimentar, posto que a questão se insere da homogeneidade do direito e não na defesa individual dos créditos dos empregados, o que torna prescindível a prévia autorização dos associados para serem representados pela entidade de classe. Precedentes do TJ/RJ e STJ. Reforma da decisão. Provimento do recurso." (20a Câm. Civ., AI no 0020352-28.2010.8.19.0000, Rel. Des. Teresa de Andrade Castro Neves, j. 4.8.2010; citado por CRISTIANO IMHOF. Lei de recuperação de empresas e falência... Op. cit., p. 186).

${ }^{473}$ Foi o que se decidiu no caso da recuperação judicial da VARIG: “... faz-se necessário dizer que, à luz das disposições legal e constitucional, respectivamente art. 37, § 5º da Lei n. 11.101/2005 e art. $8^{\circ}$, III, da CF, não há possibilidade de reconhecer a legitimidade dos sindicatos para representarem os ausentes não associados. (...) Ante o exposto, conheço dos embargos e dou-lhes provimento para declarar que sindicatos tem legitimidade para representar os associados não presentes à assembléia." ( 8 a Vara Empresarial da Comarca do Rio de Janeiro, Proc. 2005.001.072887-7, Juiz Luiz Roberto Ayoub, decisão de 23.9.2005; cf. MARIO SERGIO MiLANI. Lei de recuperação judicial... Op. cit., p. 180).

474 “Os sindicatos e a recuperação judicial”. Valor Econômico, de 15.07.2009, p. E-2, citado por FÁBIO UlhoA CoelHo (Comentários à Lei de Falências... Op. cit., p. 137). 
Caso algum trabalhador conste das relações de mais de um sindicato (o que não é nada incomum, diante da proliferação descontrolada das entidades sindicais) ${ }^{475}$, caberá ao credor esclarecer, até vinte e quatro horas antes da assembleia, qual sindicato está autorizado a representá-lo, sob pena de não ser representado em assembleia por nenhum deles (LRF, art. $37, \S 6^{\circ}$, I).

$\mathrm{Na}$ redação original do projeto de lei aprovado pelo Congresso, exigia-se ainda que o sindicato comunicasse seus associados por carta da sua intenção de representá-los a AGC. Tal exigência, constante do inciso II do $\S 6^{\circ}$ do art. 37 , acabou sendo vetada pelo presidente, por reputá-la burocrática e desnecessária, servindo apenas para restringir a atuação dos sindicatos e pondo em cheque a sua legitimidade ${ }^{476}$.

\subsection{Direitos dos credores na AGC}

No âmbito da Assembleia-Geral, palco onde serão tomadas as principais decisões relativas à crise do devedor comum, a participação dos credores se dá mediante o exercício dos seguintes direitos que lhes são conferidos pela lei: (i) direito de assento; (ii) direito de voz; (iii) direito de voto; e (iv) direito de protesto ${ }^{477}$.

\footnotetext{
${ }^{475}$ Em 4.1.2004, a Folha de São Paulo já noticiava que o Brasil ganhava um novo sindicato a cada dia. Desde então esses números só aumentaram. Recentemente foi divulgado que, segundo dados do Sistema Integrado de Relações do Trabalho (Sirt), atualizados em fevereiro de 2012, existiam 9.822 sindicatos de trabalhadores com registro ativo no País e que, só no ano de 2011, o Ministério do Trabalho recebeu 1.207 pedidos de registro de sindicatos, o que só pode ser explicado pelo indisfarçável interesse no recebimento de parcela da contribuição sindical obrigatória (cf. $O$ Globo, publicado em 5.5.2012. Disponível em: http://oglobo.globo.com/pais/brizola-neto-planeja-frear-numero-de-sindicatos-4819567. Acesso em 10.2.2013). São dados que ensejam profunda reflexão sobre a legitimidade dos sindicatos para representar os interesses dos trabalhadores nas assembleias.

${ }^{476}$ Eis as razões do veto presidencial: “(...) a disposição contida no art. $37, \S 6^{\circ}$, inciso II, que condiciona a representação sindical à prévia comunicação a seus associados, por carta, da intenção de representá-los é burocrática e desnecessária, servindo apenas para restringir ainda mais a atuação sindical, uma vez que o $\S 5^{\circ}$ do mesmo artigo determina que o sindicato representará somente os trabalhadores que não comparecerem à assembléia, garantindo, pois, a participação direta daqueles que não desejarem ser representados por sua entidade sindical. Ademais, o dispositivo abre perigosa possibilidade de impugnação da legitimidade da representação dos sindicatos e, por consequiência, da própria Assembléia-Geral, pois será difícil ter em mão milhares de comprovantes de recebimento ou de postagem para provar que todos os milhares de trabalhadores foram devidamente comunicados por carta de que o sindicato pretende cumprir seu dever de defender os interesses da categoria."

477 Vale desde logo ressaltar que, conforme ensina RENATO VENTURA RIBEIRO: "No direito de voto estão compreendidos todos os direitos e requisitos inerentes à formação de opinião e condições de ato de votar, como ingresso, presença e participação na assembleia geral, direito de palavra, proposição, protesto, pedido de informações à mesa ou à diretoria, apresentação de questões de ordem, expressão de voto, verbal ou por escrito, tudo podendo ser realizado diretamente ou por procurador constituído." (Direito de Voto nas Sociedades Anônimas. São Paulo: Quartier Latin, 2009, p. 163).
} 


\subsubsection{Direito de presença}

O direito de presença (também chamado de direito de assento) confere a prerrogativa de comparecer à assembleia e assistir aos debates e deliberações, não se confundindo com os direitos de voz ou de voto. O direito de assento defere-se exclusivamente aos credores e seus representantes, não sendo permitido o ingresso de quem não ostenta essa qualidade ${ }^{478}$.

Discorda-se da opinião de GLADSTON MAMEDE ${ }^{479}$ no sentido de permitir a qualquer pessoa (credor ou não) assistir ao conclave, em razão da publicidade que orienta os atos judiciais.

Ainda que realizada em virtude de processo judicial, a AGC não é propriamente um ato processual ${ }^{480}$, de modo que não se lhe aplica a disposição do art. 155 do Código de Processo Civil ${ }^{481}$.

A publicidade da assembleia - exigida pela ordem pública - será satisfeita com a publicação da sua convocação (no órgão oficial e em jornais de grande circulação) e com a juntada aos autos do processo da ata dos trabalhos e da lista de presença. Vale dizer, é de interesse público ter conhecimento da realização da AGC e do resultado das deliberações, mas não se defere indiscriminadamente a ciência das negociações entabuladas pelos

\footnotetext{
478 Salvo, evidentemente, o administrador judicial, o representante do Ministério Público e os agentes responsáveis pela segurança, caso se façam necessários.

479 “Não há qualquer regra legal que preveja, como regra geral, o sigilo dos atos do juízo universal, razão pela qual me parece que às assembleias gerais deve-se aplicar a regra da publicidade que orienta os atos judiciais, conforme se afere do artigo 155 do Código de Processo Civil. Qualquer um, via de consequência, pode fazerse presente à assembleia de credores e assisti-la, excetuada a hipótese de ter o Judiciário, com base no inciso I desse mesmo artigo 155, decretado segredo de justiça do processo, por exigência do interesse público" (Falência e recuperação de empresas... Op. cit., p. 109).

${ }^{480}$ Invocando as lições de Calmon de Passos, HuMBERTO THEODORO JúNIOR pondera que "não há atos processuais praticados fora o processo (...). Ato processual será aquele que o advogado praticar no processo com base no mandato ad judicia (a petição, a presença em audiência, a exceção, o recurso etc.). Da mesma forma, a transação e o pagamento continuam sendo atos de direito material, apenas com efeitos reflexos sobre o processo. Não adquirem natureza diversa apenas porque praticados durante o processo. Ato processual será o uso desses atos materiais para obter a extinção do processo, como a arguição de transação, e sua homologação pelo juiz, bem como a dedução, pela parte, da exceção de pagamento. Para, enfim, ter-se ato processual, em sentido próprio, é necessário que o ato tenha sido praticado no processo, com efeito imediato sobre ele, e que, ainda, somente possa ser praticado no processo". (Curso de Direito Processual Civil. 48 ed. Rio de Janeiro: Forense, 2008, p. 250). A confirmar esse entendimento, JORGE LOBO afirma categoricamente que a "assembleia geral de credores não é um ato processual" (In: Comentários... Op. cit., p. 143).
}

481 “Art. 155. Os atos processuais são públicos. (...)”. 
credores e o devedor durante o conclave, as quais se acham protegidas pelo sigilo ${ }^{482}$ ordinariamente esperado em qualquer contratação ${ }^{483}$. Logo, não pode ser estendido a qualquer pessoa o direito de comparecer ao conclave e assistir aos debates, que deve ser limitado apenas aos próprios credores.

Como já se disse, o direito de presença não se confunde com os direitos de voz ou de voto. Assim, mesmo que impedido de participar da deliberação, ainda resta ao credor o direito de comparecer à Assembleia ${ }^{484}$.

Tem-se defendido que todos os credores devem ser admitidos ao conclave ${ }^{485}$, estejam ou não sujeitos aos efeitos do processo concursal, posição a qual nos filiamos porque o estado de recuperação ou falência do devedor é potencialmente capaz de repercutir, ainda que indiretamente, sobre o recebimento do crédito. Além disso, admitindo-se que a recuperação judicial ou a falência passam a ser uma "solução negociada" para a crise do devedor comum, não há vantagem em alijar do processo quaisquer credores, que poderão, ao contrário, contribuir para um melhor resultado.

\subsubsection{O direito de voz}

O direito de voz $^{486}$ deferido aos credores tem relação com o chamado método assemblear, que se destina a possibilitar o contraditório ${ }^{487}$, funcionando como forma de proteção da minoria $^{488}$.

\footnotetext{
${ }^{482}$ Sigilo esse que decorre dos princípios da boa-fé e da confiança.

${ }^{483}$ Considerando-se que a deliberação e voto se aproximam dos contratos e das tratativas pré-contratuais (cf. Eduardo de Melo LuCAS COELHO. A Formação das Deliberações Gerais. Coimbra: Coimbra Editora, 1994, p. 147). No mesmo sentido, vide ÁlVARO MARIANo (Abuso de voto na recuperação judicial... Op. cit., p. 161).

${ }^{484}$ Cf. CARVALHO SANTOS, com base nas lições de Renouard: "os credores excluídos de tomar na deliberação da concordata não estão inibidos de assistir a reunião e discutir a proposta do devedor." (Tratado de direito comercial. 5 ed. Rio de Janeiro: Freitas Bastos, 1955, p. 24).

${ }^{485}$ Nesse sentido, confira-se ERASMO VALlADÃo FrançA (In: Comentários... Op. cit., p. 210). Em sentido contrário, sustentando que os credores excluídos dos efeitos da recuperação não têm direito de assento, confira-se FÁBio UlHOA COELHO (Comentários... Op. cit., p. 143, n. 85).

${ }^{486}$ Também chamado de "direito de palavra".

487 ÁlVARO MARIANO informa que o contraditório, no âmbito das deliberações assembleares, também é conhecido por princípio dialético (Abuso de voto na recuperação judicial... Op. cit., p. 154).
} 
No âmbito da Assembleia-Geral, o direito de voz tem sentido amplo, conferindo aos credores a possibilidade de fazer questionamentos ao devedor, expor as suas dúvidas e restrições acerca da proposta em votação, estimular os demais participantes a aprovar ou rejeitar determinada matéria, enfim, fazer todas e quaisquer ponderações que repute relevantes para a deliberação ${ }^{489}$.

Em regra, o debate sobre as matérias da ordem do dia precede a votação, cabendo ao presidente do conclave disciplinar o modo de exercício do direito de voz, a fim de evitar um tumulto generalizado. Havendo necessidade, parece razoável que estipule um tempo máximo para que cada credor se manifeste acerca das matérias em votação, ou mesmo que casse a palavra de quem falte com o decoro ${ }^{490}$.

\subsubsection{O direito de voto}

Superada a fase de debates, passa-se à deliberação, oportunidade em que os credores legitimados poderão votar as matérias postas na ordem do dia, expressando a sua aprovação ou rejeição em relação a elas ${ }^{491}$.

Entre as várias definições possíveis ${ }^{492}$, pode-se afirmar que o voto consiste no ato pelo qual o credor manifesta a sua vontade ${ }^{493}$, no âmbito da assembleia e em obediência das formalidades legais, para que seja formada a deliberação coletiva.

\footnotetext{
${ }^{488}$ Cf. ERASMO VAlLADÃo FRANÇA, com base nas lições de Galgano (Invalidade das deliberações de assembléias da S/A... Op. cit., p. 37).

489 "Trata-se do Debattrecht, que deve ser entendido em face da nossa lei como prerrogativa autônoma e plena, inteiramente desvinculada do outro direito, que é o de voto. Não é, portanto, o direito de participação meramente propiciatório ou preparatório do exercício do voto, uma vez que não está vinculado a ele." (Modesto Carvalhosa. Comentários à Lei de Sociedades Anônimas... Op. cit., v. 2, p. 125).

${ }^{490}$ Cf. PONTES DE MIRANDA, tratando da assembleia da S.A.: "Pode o presidente da assembléia geral: a) fixar o tempo que tem cada acionista para falar a propósito de cada assunto posto em exame ou discussão; b) permitir resposta a quem já usou do tempo se outrem fez pergunta; c) submeter à assembléia geral a expulsão de acionista que está perturbando a reunião, ou empregando termos violentos, agressivos ou imorais." (Tratado de Direito Privado. 2 ed. Rio de Janeiro: Borsoi, 1960, t. 50, § 5.321, item 6).

491 Para RENATO VENTURA RIBEIRO, o voto "representa a aceitação ou rejeição, pelo acionista, da proposta apresentada em assembléias" (Direito de Voto nas Sociedades Anônimas. São Paulo: Quartier Latin, 2009, p. 157).

492 Eduardo De Melo LuCAs COElho define o voto como sendo "a forma pela qual o membro da assembleia da sociedade, titular desse direito, exprime, nesta fase, a sua posição pessoal acerca da proposta."
} 
Acerca da natureza jurídica do voto, debate-se se teria o caráter de ato jurídico em sentido estrito ${ }^{494}$, ou se seria negócio jurídico unilateral ${ }^{495}$. Além disso, discute-se se o voto seria uma declaração de vontade ou de verdade ${ }^{496}$ (ou, ainda, se seria ambos ${ }^{497}$ ).

O direito de voto, em si, também é objeto de controvérsia. Para alguns, trata-se de instrumento de realização do interesse social ${ }^{498}$, ou uma espécie de "poder funcional", já que não serviria à tutela do interesse do próprio titular, mas, sim, à tutela do interesse coletivo. Outros afirmam que o direito de voto constituiria efetivo direito subjetivo ${ }^{499}$, conferindo ao titular liberdade para agir conforme os próprios interesses, ainda que limitado pelo interesse social (qualificado como um "limite externo" ao exercício do direito de voto). E ainda existem teorias intermediárias, que situam o direito de voto entre o direito subjetivo e o poder funcional. Seus partidários defendem que, embora o titular não seja obrigado a exercer o voto (atribuindo-lhe, por isso, o caráter de direito subjetivo),

(A Formação das Deliberações Gerais... Op. cit., p. 67). WiLson DE SouZA CAMPOS BatalHA afirma que “o voto constitui declaração unilateral de vontade do órgão social, obedecidos os pressupostos legais (Comentários à Lei das Sociedades Anônimas. Rio de Janeiro: Forense, 1977, p. 551). Para JosÉ EDWALDO TAVARES BORBA, "o voto é uma manifestação individual e unilateral de vontade, tendente a produzir uma decisão coletiva” (Direito Societário. 10 ed. Rio de Janeiro: Renovar, 2007, p. 345).

493 "Voto é declaração de vontade", afirma ERASMO VALLADÃo FrANÇA, com amparo nas lições de Karsten Schmidt (In: Comentários... Op. cit., p. 191).

${ }^{494}$ Acerca da questão, confira-se ÁlVARO MARIANO. Abuso de voto na recuperação... Op. cit., p. 139.

495 WILSON DE SOUZA CAMPOS BATALHA comenta que, na opinião do Professor espanhol Rodrigo Uria, "a manifestação do voto constitui um negócio jurídico unilateral. É uma declaração de vontade não receptícia, destinada a unir-se com as declarações de vontade dos demais sócios e fundir-se com elas em um acordo coletivo, expressão da vontade social" (Comentários à Lei das Sociedades Anônimas... Op. cit., p. 550).

${ }^{496}$ Cf. GIUSEPPE SENA. Il voto nella assemblea della società per azioni. Milão: Giuffrè, 1958, p. 19.

${ }^{497}$ Acertadamente, MODESTO CARVALHOSA defende que o voto tanto poderá ser um ato de vontade quando de verdade, dependendo do objeto da votação (In: Comentários à nova lei de falência... Op. cit., p. 277)

498 "Segundo uma primeira corrente, representada, entre outros, por Carnelutti, Candian, Oppo, Salandra, Vaselli, Auletta, De Gregorio, Fre, De Martini, Greco, Asquini, Pasteris, Messineo e Ondei, o sócio tem o dever jurídico de perseguir, no exercício do direito de voto, o interesse social. Para os partidários dessa corrente, o acionista ao votar em uma assembléia, não exerce verdadeiro direito subjetivo, vale dizer, não tutela um interesse próprio, do qual é o único titular, mas sim um interesse coletivo, que se refere a todos os outros sócios." (ERASmo VAlladẽo FrançA. Conflito de interesses nas assembléias de S.A. São Paulo: Malheiros, 1993, p. 43).

499 "Segundo outra corrente, representada por Mengoni, Ghidini, Ferri, Cottino, Filbinger e Gower, o interesse social é concebido não como um limite funcional, mas como um limite externo ao exercício do voto, com o que se admite que o sócio possa livremente perseguir interesses extra-sociais desde que, com isso, não se coloque em contraste com o interesse comum de todos. (...) para a corrente ora analisada o sócio não se encontra adstrito a perseguir o interesse social. Antes, é livre para perseguir seus próprios interesses, funcionando aquele conceito como um limite a essa persecução. Nessa perspectiva, portanto, o voto é encarado como direito subjetivo, enquanto poder concedido para a tutela de um interesse próprio e não alheio" (Idem, p. 44). 
ao exercê-lo deverá sempre visar ao interesse social, em razão do que constituiria uma espécie de direito-dever $)^{500}$.

É preciso ressalvar, no entanto, que todas essas teorias foram elaboradas em torno das sociedades comerciais, de modo que a sua aplicação, no âmbito da AssembleiaGeral de Credores, demanda certos temperamentos.

Se na sociedade os sócios se reúnem voluntariamente, com vistas à persecução de um interesse comum, a reunião de credores se dá de forma acidental, por fato que lhes é involuntário. Os credores não se reúnem visando a interesse comum; visam, cada qual, ao recebimento do próprio crédito ou à manutenção da sua relação com o devedor. Assim, inexistindo comprometimento coletivo com uma finalidade predeterminada, como ocorre na assembleia, a teoria do voto como poder funcional, ao menos aqui, deve se rejeitada.

Por outro lado, apesar de haver limitações ao direito de voto (assim como existem ao exercício de quaisquer direitos) ${ }^{501}$, é preciso muito cuidado ao afirmar que ele estaria limitado pelo interesse coletivo dos credores. Em primeiro lugar, porque é duvidosa a própria existência desse interesse coletivo. Em segundo lugar, porque se trata de conceito fluido e que não se acha pré-estabelecido.

De qualquer forma, é pelo voto que o credor participa diretamente da deliberação, a qual terá efeito sobre todos os demais, ainda que ausentes ou dissidentes. Não se trata, porém, de uma obrigação ${ }^{502}$, pois mesmo legitimado e presente ao conclave, o credor poderá se abster de votar, ou votar em determinadas matérias e se abster de votar

\footnotetext{
${ }^{500}$ Esta é a opinião de MARCELO LAMY REGO: "Entendemos que o voto é ao mesmo tempo direito subjetivo e direito-dever; é direito subjetivo porque o acionista pode exercê-lo ou não; mas, com relação ao conteúdo do voto, é direito-dever, uma vez que deve ser exercido no interesse da companhia (...). Seguimos a lição de Asquini (1959, p. 631), de que o direito de voto é direito de dupla face, de um lado direito subjetivo para tutela de interesse individual do acionista e, de outro, poder concedido ao acionista no interesse social" (In: LAMY FILHO, Alfredo; e BULHÕES PEDREIRA, José Luiz (Coords.). Direito das Companhias. Rio de Janeiro: Forense, 2009, v. 1, p. 379). No mesmo sentido, adotando essa posição intermediária, confira-se GIUSEPPE SENA. Il voto nella assemblea della società per azioni... Op. cit., p. 151-152).

${ }^{501}$ Código Civil, art. 187.

502 "o voto é um direito e não uma obrigação" (MODESTO CARVALHOSA. In: Comentários à nova lei de falência... Op. cit., p. 277).
} 
em outras ${ }^{503}$. No entanto, jamais poderá abdicar do direito de voto, que é irrenunciável e inderrogável ${ }^{504}$, vedando-se ainda a sua negociação ${ }^{505}$.

Também por exigência da sinceridade, o voto é indivisível em relação ao credor $^{506}$, não se permitindo que vote pela aprovação com uma parte do crédito e pela rejeição com a outra parte. Cuidando-se, todavia, de créditos de natureza diferente, inseridos em classes diversas, em tese seria possível que o credor não votasse do modo em cada uma delas ${ }^{507}$. No mais das vezes, porém, excetuadas as deliberações relativas à indicação de representante para compor o Comitê, o titular de créditos em mais de uma classe acha-se em situação de flagrante conflito de interesses, devendo votar apenas na classe em que possui o crédito de maior relevância. Do contrário, acabaria votando na classe ' $A$ ' para atender os interesses que possui na classe ' $\mathrm{B}$ ', comprometendo a legitimidade da deliberação estratificada.

O voto é manifestado pelo credor na assembleia, pessoalmente ou por representante $^{508}$. Não são permitidos votos por correspondência, telegrama, telefone, fax, e-mail etc, pois faz parte do processo deliberativo o prévio debate das matérias ${ }^{509}$.

O sentido do voto deve ser manifestado publicamente, vedado o voto secreto $^{510}$. Uma vez proferido, é irretratável ${ }^{511}$.

\footnotetext{
${ }^{503}$ A abstenção, também chamada de voto em branco, não é computada no quórum de deliberação. Confirase, a propósito, o art. 129 da Lei das S.A.: "As deliberações da assembléia-geral, ressalvadas as exceções previstas em lei, serão tomadas por maioria absoluta de votos, não se computando os votos em branco."

${ }^{504}$ Cf. Modesto Carvalhosa. (In: Comentários à nova lei de falência... Op. cit., p. 277).

${ }^{505}$ Vide item 8.3.3.1, abaixo.

506 “sendo o voto expressão da vontade do sócio, não pode ser contraditório. Consequentemente, não se pode permitir que o sócio, com uma parte das ações, vote favoravelmente a uma deliberação e, com outra, vote contrariamente" (PRISCILA CORRÊA DA FONSECA. Suspensão das deliberações sociais. São Paulo: Saraiva, 1986, 91).

${ }^{507}$ P. ex., quando a proposta em votação atendesse aos interesses de uma classe, mas contrariasse os da outra.

${ }^{508} \mathrm{O}$ representante poderá ser legal ou voluntário. Além disso, os sindicatos de trabalhadores poderão representar seus associados titulares de créditos derivados da legislação do trabalho ou decorrentes de acidente de trabalho que não comparecerem, pessoalmente ou por procurador, à assembleia. A propósito do tema, confira-se o item 8.2 deste Capítulo.

${ }^{509}$ Cf. ERasmo Valladão França (In: Comentários... Op. cit., p. 205).

${ }^{510}$ Cf. Marlon Tomazette (Curso de Direito Empresarial... Op. cit., p. 136). No mesmo sentido, ÉCIO PERIN JÚNIOR (Curso de direito falimentar e recuperação de empresas. 3 ed. São Paulo: Método, 2006, p. 243). Se o voto fosse secreto, não seria possível, p. ex., exercer controle judicial acerca do seu conteúdo, especialmente em casos de conflito de interesses ou de abuso de direito. Além disso, daria margem a inúmeras manobras oportunistas, em prejuízo da boa-fé que deve reinar na deliberação.
} 
O escrutínio, à falta de regra específica, deve ser feito pelos métodos tradicionais, como a chamada nominal dos credores (em que cada um profere o seu voto de viva voz, dizendo "sim" ou "não", "a favor" ou "contra"), ou, p. ex., concitando-se os credores a favor de determinada proposta a levantarem a mão. Além disso, "nada impede que se utilizem os recursos da informática, sendo então os votos tabulados em planilhas adrede concebidas para identificar o sentido de cada voto e fornecer o resultado das votações, como vem ocorrendo nas Assembléias Gerais de credores, realizadas sob a égide da Lei de Falências de 2005, onde o afluxo de participantes é muito grande”. 512

Se assim o desejar, o credor poderá declarar por escrito as razões do seu voto $^{513}$, as quais deverão constar da ata ou ser por ela referidas, caso lavrada na forma de sumário. A declaração de voto poderá ser conveniente para afastar suspeita de conflito de interesses ou de abuso de direito ${ }^{514}$.

\subsubsection{Vedação à negociação do voto.}

O credor não poderá ceder ou alienar, por qualquer meio, o seu direito de voto $^{515}$. Apesar da ausência de norma expressa nesse sentido ${ }^{516}$, tal proibição é extraída do sistema, dado que o voto tem de ser expressão da verdade ${ }^{517}$.

\footnotetext{
${ }^{511}$ CARVALHO DE MENDONÇA ensina que "depois de dissolvida a assembléia, nenhum credor poderá retratar o seu voto, aceitando ou rejeitando a concordata, ainda que se procedam de novo as diligências legais". Ainda a respeito do tema, cita precedente publicado no volume $1^{\circ}$, pág. 48 , da Revista do Supremo Tribunal Federal: "Que precedente de terríveis consequências seria admitir-se a retratação, posteriormente aos que votaram a favor ou contra a concordata nas assembléias de credores! Basta supor que se houvesse unanimidade de votos, o juiz teria de homologar imediatamente a concordata, e que garantia oferecia essa homologação, desde que se admitisse que qualquer dos credores que votaram a favor pudesse posteriormente à assembléia retratar-se, declarando que, tendo votado a favor, votava agora contra!" (Tratado de Direito Comercial Brasileiro... Op. cit., v. 8, p. 536).

${ }^{512}$ RICARDO TEPEDINO. Direito das Companhias... Op. cit., v. 1, p. 949.

${ }^{513}$ Todavia, cuida-se de expediente pouco comum na prática. Em regra, os credores se limitam a responder "sim" ou "não" à proposta em votação.

${ }^{514}$ Assim como se passa na sociedade anônima: "O acionista não está obrigado a motivar o seu voto. Mas convém que o faça em certos casos para afastar a imputação de exercício abusivo do direito de voto" (AlFredo SÉrgio LAZZARESChi Neto. Lei das Sociedades por Ações anotada ... Op. cit., p. 218).

${ }^{515}$ Cf. TRAJANO DE MiRANDA VALVERDE, “o voto é a expressão do crédito, e, por isso, deste inseparável. Não é, conseguintemente, possível negociar o direito de voto, mera representação, para outros efeitos, do crédito, cujo valor determina a potência do voto" (A Fallencia no Direito Brasileiro... Op. cit., v. 2, p. 55). No mesmo sentido, ERASMO VALlADÃo FranÇA complementa: "Vale dizer: pode-se ceder o crédito (e com ele o voto), mas não é possível separar uma coisa da outra" (In: Comentários... Op. cit., p. 210).
} 
Enquanto manifestação unilateral de vontade, o voto deve corresponder à intenção de quem o profere e contemplar os interesses deste, impondo-se a sinceridade ${ }^{518}$. Admitir-se o contrário implicaria violação do princípio da par condicio creditorum e subversão total da lógica do sistema, especialmente nas deliberações sujeitas às classes, em que a qualidade do credor é fundamental para a legitimidade da decisão ${ }^{519}$.

Acrescente-se que, em leis falimentares anteriores ao Decreto-Lei $\mathrm{n}^{\mathrm{o}}$ 7.661/45, a negociação de voto pelos credores era tipificada criminalmente. Assim dispunha, p. ex., o art. $171, \S 10^{\circ}$, do Decreto $\mathrm{n}^{\circ} 5.746 / 29$ : “Incorrerão nas penas da fallencia fraudulenta: (...) o credor legitimo que fizer com devedor ou com terceiro qualquer concerto em prejuizo da massa, ou transigir com o seu voto para obter vantagens para si nas deliberações e actos de concordata preventiva ou formada na fallencia, na quitação e reabilitação”. Disposições semelhantes são encontradas na Lei no 2.024/1908 (art. 170, § $10^{\circ}$ ), na Lei ${ }^{\circ}$ 859/1902 (art. 88, VI) e no Decreto $n^{\circ}$ 917/1890 (art. 81, VI). O

O Decreto-Lei n ${ }^{\mathrm{o}} 7.661 / 45$ operou a abolitio criminis dessa figura penal, o que de certo modo é explicado em razão da desimportância da AGC no sistema que instituiu. Ocorre que as disposições penais da Lei $\mathrm{n}^{\circ}$ 11.101/2005, em muito inspiradas na lei anterior, não reestabeleceram o crime de venda de voto, omissão que, s.m.j., demanda correção nas próximas revisões legislativas.

Ainda a propósito do tema, AlEXANDRE Alves LAZZARINI ${ }^{520}$ defende que, por ser inegociável, o voto se dissociaria do direito de crédito, de modo que, mesmo com a cessão deste, o cessionário não adquire o direito de votar. Essa interpretação se justificaria,

\footnotetext{
${ }^{516} \mathrm{O}$ art. $177, \S 2^{\circ}$, do Código Penal dispõe que, no âmbito da sociedade anônima, comete crime o acionista que negocia o voto nas deliberações de assembléia-geral, a fim de obter vantagem para si ou para outrem.

${ }^{517} \mathrm{Na}$ Itália, "a sinceridade do voto [do credor] é garantida por uma norma de caráter penal que tipifica o crime de mercado de voto (art. 233)" (ALBERTO MAFFEI ALBERTI. Commentario breve ala legge fallimentare. 4 ed. Milão: Cedeam, 2000, p. 562). No original: "La sincerità del voto è garantita da una norma di carattere penale che configura il reato di mercato di voto (art. 233)".

518 “Adquirindo todos os credores com o desastre econômico do devedor direitos iguais, não são toleráveis os concertos particulares com o devedor. Impõem-se, portanto, não somente a sinceridade do seu voto nas deliberações da falência, como o mais perfeito respeito à igualdade dos credores perante o ativo da falência, evitando a violação da par conditio" (CARVALHO DE MENDONÇA. Tratado de Direito Comercial Brasileiro... Op. cit., v. 8, p. 579).

${ }^{519}$ Fosse admitida a venda de voto, então um credor quirografário poderia votar, p. ex., segundo os interesses de credor com garantia real, em prejuízo dos interesses de toda a classe.

520 "Reflexões sobre a recuperação judicial de empresas". In: DE LUCCA, Newton [et. al.] (Coord.). Direito Recuperacional. São Paulo: Quartier Latin, 2009. p. 130-131.
} 
segundo ele, para atender à finalidade do instituto da recuperação, de modo a evitar certas condutas perniciosas, como a do devedor que, por interposta pessoa, compra os créditos de seus credores para aprovar o seu plano de recuperação judicial, ou a compra de créditos pelos concorrentes do devedor, com o só propósito fazer rejeitar o plano.

Conclui, assim, que:

"O direito de voto de voto é um atributo do credor originário e tornase uma condição personalíssima do credor originário, ou seja, daquele que forneceu produtos, serviços ou capital à empresa em crise e, assim, não negociável, não se confundido com um acessório, ou seja, juros e outros encargos contratuais".

Compreendem-se as preocupações do autor, mas discorda-se da solução dada. Talvez fosse mesmo conveniente que a lei limitasse o direito de voto de quem adquiriu o crédito depois de deferido o processamento da recuperação judicial ${ }^{521}$, mas à falta de norma nesse sentido não é possível excluir o voto do cessionário com base na pressuposição absoluta de abuso (até porque a má-fé não se presume).

O direito de voto na AGC integra o feixe de direitos que compõem o crédito e não pode dele ser dissociado, transferindo-se, portanto, a quem adquire o crédito ${ }^{522}$. Eventual abuso cometido pelo cessionário no exercício desse direito poderá ser repelido, mas só no caso concreto, e não por antecipação ${ }^{523}$.

Nesse sentido, reconhecendo que o cessionário de crédito tem direito de participar da AGC com voz e voto, assim tem decidido, acertadamente, o Tribunal de Justiça de São Paulo:

\footnotetext{
${ }^{521}$ A Lei $n^{\circ} 11.101 / 2005$ não ignora a questão da cessão de crédito, estabelecendo que não se compensam os créditos transferidos após a decretação da falência (salvo em caso de sucessão por fusão, incorporação, cisão ou morte), nem os créditos, ainda que vencidos anteriormente, transferidos quando já conhecido o estado de crise econômico-financeira do devedor ou cuja transferência se operou com fraude ou dolo (art. 122, p. u.). Cuida-se de norma que visa, justamente, a evitar a cessão de crédito fraudulenta.

522 "pode-se ceder o crédito (e com ele o voto), mas não é possível separar uma coisa da outra" (ERASMO VALladẽo FranÇA. In: Comentários... Op. cit., p. 210).

${ }^{523}$ Nesse sentido, confira-se Luiz Fernando Valente de Paiva e Giuliano Colombo. "Recuperação judicial e cessão de créditos: a polêmica do direito de voto". Revista do Advogado, São Paulo, n. 105, p. 107$114,2009$.
} 
“Agravo de Instrumento. Recuperação Judicial. Endossatário de título de crédito (nota promissória). O endosso transmite todos os direitos emergentes da cambial. (...) Direito de participar da Assembléia Geral de Credores com voz e voto, este na proporção do valor do crédito que lhe foi transferido.

(...) O indeferimento ao pedido de participar com direito de voz e voto nas Assembléias Gerais de Credores decorreu do entendimento de que o endossatário não tem interesse na recuperação da empresa, mas sim e tão-só no recebimento de seu crédito e que o direito de voto é personalíssimo e não pode ser alienado (fls.67/78). Não há, 'venia concessa', qualquer fomento jurídico ou legal para tal entendimento.

(...) alegando e comprovando o agravante sua condição de endossatário e titular do crédito mencionado na cambial e, portanto, credor, tem ele o direito de votar na Assembléia de Credores a ser realizada na recuperação judicial da devedora, e eis que o direito de voto decorre da simples circunstância de sua situação jurídica de credor, inexistindo qualquer norma legal que confira ao direito de voto decorrente do crédito marca da inalienabilidade ou do personalismo". 524

\subsubsection{Cômputo do voto}

Em regra, o voto do credor será proporcional ao valor de seu crédito ${ }^{525}$ (LRF, art. 38, caput $^{526}$, segundo tenha sido admitido na forma do art. 39, caput, da LRF $^{527}$. Isso vale para todas as deliberações ${ }^{528}$, exceto para a aprovação, rejeição ou modificação do plano de recuperação, que se submete a regra específica. Presume a lei que, quanto maior o valor do crédito, maiores serão a relevância do interesse do credor e o risco por ele suportado, a justificar a proporcionalidade entre o voto e o valor do crédito.

\footnotetext{
${ }^{524}$ Câm. Recup. e Fal., AI no 431.567-4/0-00, rel. Des. Pereira Calças, j. 15.3.2006. No mesmo sentido, confira-se, da mesma Câmara, o AI no 430.714-4/4-00 e o AI no 433.182-4/7-00.

525 “Assim, se a assembleia acontece quando o administrador judicial já fez publicar a sua relação de credores e dela consta que Antonio titulariza um crédito de $\$ 100$ e Benedito, de $\$ 50$, àquele será dado proporcionalmente o dobro de votos concedidos a este último" (FÁBIo UlhoA CoElHo. Comentários... Op. cit., p. 139).

${ }^{526}$ Art. 38. O voto do credor será proporcional ao valor de seu crédito, ressalvado, nas deliberações sobre o plano de recuperação judicial, o disposto no $\S 2^{\circ}$ do art. 45 desta Lei.

${ }^{527}$ A propósito, vide os itens 2.1 e 2.2 deste Capítulo.

${ }^{528}$ Isto é, para as deliberações relativas às matérias descritas art. 35, inciso I, alíneas "b" a "f” (com a exceção da alínea "c", que foi vetada), e inciso II, alíneas "b" a "d".
} 
Exclusivamente na deliberação que tenha por objeto a aprovação, rejeição ou modificação do plano de recuperação apresentado pelo devedor, o voto será computado de fora diversa da regra geral. Aqui, a deliberação se sujeita à votação nas três classes de credores definidas pelo art. 41, sendo que, no âmbito da Classe I, composta pelos titulares de créditos derivados da legislação do trabalho ou decorrentes de acidentes de trabalho, os votos serão computados exclusivamente por cabeça, independente do valor do crédito (LRF, art. $45, \S 2^{\circ}$ ). Vale a regra “one man, one vote".

Já na Classe II, composta pelos credores com garantia real, e na Classe III, integrada pelos demais, o cômputo dos votos obedece a duplo critério: será proporcional ao valor crédito, mas também será contado por cabeça, dependendo a aprovação do atingimento do quórum deliberativo segundo ambos os critérios.

Na hipótese de cram down, em que a recuperação judicial poderá ser concedida a despeito da desaprovação de uma das classes ${ }^{529}$, serão obedecidas as mesmas regras para a verificação do quórum deliberativo internamente a cada uma das classes (LRF, art. 58, III). Nesse caso, porém, a aprovação do plano dependerá ainda dos votos favoráveis de mais da metade do valor de todos os créditos presentes à assembleia, independentemente de classe, o que significa que os votos dos credores da Classe I (trabalhistas) também serão computados proporcionalmente ao valor do crédito, sujeitando-se a um critério no âmbito da própria classe ("por cabeça") e a outro no âmbito global ("por valor").

Por analogia ao art. 129 da Lei das S.A., não são computados os chamados "votos em branco" "530. Logo, a abstenção do credor presente à assembleia não é levada em conta na verificação do quórum de deliberação ${ }^{531}$ :

\footnotetext{
${ }^{529}$ Mesmo não se logrando obter a aprovação das três classes de credores, o juiz poderá conceder a recuperação judicial desde que, na assembleia, (i) ao menos duas das classes de credores tenham aprovado o plano, (ii) a soma dos créditos daqueles que votaram favoravelmente ao plano represente mais da metade do valor de todos os créditos presentes à assembleia, independentemente de classe; (iii) na classe que o houver rejeitado, mais de 1/3 (um terço) dos credores tenham votado favoravelmente; e (iv) o plano não implique tratamento diferenciado entre os credores da classe que o houver rejeitado (LRF, art. 58).

${ }^{530}$ No âmbito das sociedades anônimas, assim se manifesta Modesto CARVAlHOSA: "O quorum de deliberação é formado unicamente por aquelas ações votantes que efetivamente se manifestaram sobre a proposta respectiva a favor ou contra. Exclui-se desse cômputo os votos em branco, neles compreendidos os que nada declaram, os que se abstiveram ou os que votaram fora de matéria da pauta". (Comentários à Lei de Sociedades Anônimas... Op. cit., v. 2, p. 129).
} 
"O valor do crédito de credor que comparece à assembléia de credores e se abstém de votar não deve ser considerado na aferição do quorum de deliberação sobre o plano de recuperação. Inteligência do parágrafo $1^{\circ}$ do artigo 45 , da Lei $n^{\circ} 11.101 / 2005$. (...)

Diante da importância da deliberação sobre o plano de recuperação judicial e atento ao princípio maior da recuperação da empresa, que informa a Lei $\mathrm{n}^{\circ} 11.101 / 2005$, e que não tem regra própria para a hipótese de credor presente à Assembléia que se abstenha de votar, deve-se aplicar, nos termos do artigo $4^{\circ}$ da Lei de Introdução do Código Civil, por analogia, o disposto no artigo 129 da Lei das Sociedades Anônimas, 'in verbis': 'As deliberações da assembléia geral, ressalvadas as exceções previstas em lei, serão tomadas por maioria absoluta de votos, não se computando os votos em branco'.

O credor que se abstém de votar, evidentemente, não vota pela aprovação, nem pela rejeição do plano de recuperação, ou seja, sua inércia tem o mesmo efeito do que vota em branco, mercê do que, entendo que o seu crédito não pode ser computado para os fins do parágrafo $1^{\circ}$ do artigo 45 , da Lei ${ }^{\circ} 11.101 / 2005^{, 532}$.

\subsubsection{1. $O$ voto do titular de crédito em moeda estrangeira}

$\mathrm{Na}$ recuperação judicial, tratando-se de crédito em moeda estrangeira, o cômputo do voto do seu titular tomará por base o valor convertido para moeda nacional pelo câmbio $^{533}$ da véspera da data de realização da assembléia ${ }^{534}$ (LRF, art. 38, p.u.).

Essa regra é criticada por JULIO KAHAN MANDEL ${ }^{535}$, para quem o valor do crédito deveria ser convertido pelo câmbio da data do pedido de recuperação, a fim de preservar todos de uma possível flutuação cambial.

\footnotetext{
${ }^{531}$ Em sentido contrário, defendendo que a abstenção deve ser computada e interpretada como voto favorável à aprovação do plano de recuperação, confira-se Alexandre Alves Lazzarini ("Reflexões sobre a recuperação judicial de empresas"... Op. cit., p. 131-132). Trata-se, todavia, de posicionamento isolado.

532 TJSP, Câm. Fal. e Recup., Emb. Decl. no 429.622-4/5-02, rel. Des. Pereira Calças, j. 30.8.2006; citado por EdUARDo Foz MANGE (Assembleia-Geral de Credores na recuperação judicial. Dissertação de mestrado, São Paulo: Faculdade de Direito da PUC-SP, 2010. p. 53). No mesmo sentido, da mesma Câmara, confira-se: AI n 0372448-49.2010.8.26.0000, rel. Des. Pereira Calças, j. 1 ${ }^{\circ} .2 .2011$, e AI nº 0526210-85.2010.8.26.0000, rel. Des. Eliot Akel, j. 17.5.2011.

533 "Entendemos que o Câmbio deverá ser calculado, salvo diversa estipulação no contrato, pelo valor de venda, que é o valor, afinal, que servirá para saldar a dívida" (ERASMO VALlADÃo FrAnÇA. In: Comentários... Op. cit., p. 208).

${ }^{534} \mathrm{Na}$ falência, o valor do crédito é convertido pelo câmbio da data da sentença de quebra (LRF, art. 77).

535 "Mantém-se o equívoco da lei anterior, no sentido de somente fechar o câmbio em momento posterior à impetração do benefício. O correto seria efetuar a conversão pela data da impetração do benefício,
} 
Por outro lado, FÁBio UlhoA Coelho destaca que desde 1999 o Brasil adota o regime de câmbio flutuante, de modo que não existe uma taxa oficial de conversão fixada ou praticada pelo Banco Central. Por isso, sugere que o juiz deverá eleger a taxa de câmbio praticada por um determinado banco ou divulgada em certo veículo jornalístico.

A crítica é pertinente. No entanto, vale lembrar que embora o Banco Central não estabeleça uma taxa de câmbio oficial, ele coleta e divulga as taxas médias praticadas no mercado interbancário, isto é, a taxa média do dia apurada com base nas operações realizadas, conhecida por "taxa PTAX", a qual poderá ser utilizada como referência para fins de conversão do crédito em moeda estrangeira (notadamente porque a conversão é feita com base na taxa apurada na véspera da AGC, quando já divulgada a informação pelo Banco Central). Parece-nos preferível a utilização dessa taxa ("média") àquela praticada apenas por um determinado banco.

\subsubsection{Credores sem direito de voto}

Logicamente, os credores excluídos dos efeitos da recuperação judicial ou da falência não terão direito de voto, nem serão computados para a verificação dos quóruns de instalação e de deliberação na assembleia. Além disso, a lei também exclui o voto de certos credores sujeitos aos efeitos do processo concursal, sendo que alguns deles têm esse direito cerceado apenas na recuperação judicial, enquanto que outros não poderão votar nem mesmo na falência.

Como regra geral, pode-se afirmar que não terão direito de voto os credores que, por ocasião da assembléia, não tenham tido a sua condição reconhecida conforme a fase em que se acha o processo, conforme estabelece o art. 39, caput, da $\mathrm{LRF}^{536}$, valendo ressaltar que "as deliberações da assembléia-geral não serão invalidadas em razão de posterior decisão judicial acerca da existência, quantificação ou classificação de créditos” (LRF, art. 39, § $2^{\circ}$ ).

preservando todos contra uma posterior flutuação cambial, favorável de forma injusta ao devedor ou ao credor" (Nova lei de falências... Op. cit., p. 205, p. 87).

${ }^{536}$ Vide item 2.1, acima. 
Nas assembleias realizadas durante a recuperação judicial, não terão direito de voto os credores que não se submetem aos seus efeitos. Assim, ficam desde logo excluídos os titulares de créditos constituídos após a distribuição do pedido de recuperação judicial (já que a ela se sujeitam apenas os créditos existentes na data do pedido, ainda que não vencidos $^{537}$ ).

Pelo mesmo motivo, isto é, por não se sujeitarem aos efeitos da recuperação judicial, não terão direito de voto:

(i) os credores de dívidas fiscais (LRF, arts. $6^{\circ}, \S 7^{\circ}, 57$ e 68 , e CTN, art. 187);

(ii) os credores titulares da posição de proprietário fiduciário de bens móveis ou imóveis, arrendador mercantil, o proprietário ou promitente vendedor de imóvel cujos respectivos contratos contenham cláusula de irrevogabilidade ou irretratabilidade, inclusive em incorporações imobiliárias, ou de proprietário em contrato de venda com reserva de domínio (LRF, art. 49, § $3^{\circ}$ );

(iii) os titulares de créditos decorrentes de adiantamento a contrato de câmbio para exportação $^{538}$ (LRF, art. 49, § $4^{\circ}$ c.c. art. 86, II); e

(iv) os titulares de créditos decorrentes de obrigações assumidas no âmbito das câmaras ou prestadoras de serviços de compensação e de liquidação financeira (LRF, art. 193).

Note-se que o art. $39, \S 1^{\circ}$, da LRF dispõe que "não terão direito a voto e não serão considerados para fins de verificação do quórum de instalação e de deliberação os titulares de créditos excetuados na forma dos $\$ \S 3^{\circ}$ e $4^{o}$ do art. 49 desta Lei”. A rigor,

\footnotetext{
${ }^{537}$ LRF, art. 39, caput.

${ }^{538}$ No adiantamento a contrato de câmbio para exportação, ou ACC, o exportador, após contratar a venda de seu produto ao Exterior, procura o agente de câmbio, obtendo em moeda nacional o valor que receberia, após a entrega do produto. Entregue o produto no Exterior, o importador paga diretamente ao banco, liquidando-se a operação. Caso o exportador não entregue o produto e sua falência seja decretada, o banco pode pedir a restituição da importância adiantada (LÍDIA VALÉRIO MARZAGÃO. “A recuperação judicial” In: MACHADO, Rubens Approbato (coord.). Comentários à nova lei de falências e recuperação de empresas. 2 ed. São Paulo: Quartier Latin, 2007, p. 89).
} 
trata-se de norma desnecessária ${ }^{539}$, uma vez que, por estarem excluídos dos efeitos da recuperação, esses créditos logicamente não poderiam compor a AGC.

Por outro lado, a regra do art. $39, \S 1^{\circ}$, da LRF só se aplica às assembleias realizadas durante a recuperação, eis que os credores referidos nos parágrafos $3^{\circ}$ e $4^{\circ}$ do art. 49 têm direito de voto nas assembleias realizadas na falência ${ }^{540}$.

Há certos credores que não poderão votar em nenhuma deliberação da AGC, ainda que sujeitos aos efeitos da recuperação judicial. É o caso dos sócios do devedor e das sociedades com vinculação societária relevante (acima de $10 \%$ do capital social) com o devedor ou seus sócios. O mesmo vale para o cônjuge ou parente até o segundo grau do devedor, seu sócio controlador, seus administradores, membros dos seus conselhos fiscais, consultivos ou semelhantes, e ainda para as sociedades onde tais pessoas exerçam essas funções (LRF, art. 43, caput e parágrafo único) ${ }^{541}$. Não poderão votar nem mesmo nas assembleias realizadas na falência.

Também ficam privados do direito de voto, nas assembleias realizadas durante a recuperação judicial, os chamados "credores retardatários", que habilitaram os seus créditos depois do prazo previsto no art. $7^{\circ}, \S 1^{\circ}$, da LRF, excetuados os titulares de créditos derivados da relação de trabalho (LRF, art. 10, $\S 1^{\circ}$ ). Já nas assembleias realizadas na falência, concede-se direito de voto aos credores integrantes das Classes II e III se, na data da realização da assembléia-geral, já houver sido homologado o quadro-geral de credores contendo o crédito retardatário (LRF, art. 10, $\S 2^{\circ}$ ).

\footnotetext{
539 "A disposição se nos afigura totalmente despicienda. Os parágrafos em alusão na norma em comento cuidam de créditos ou direitos que não se submetem aos efeitos da recuperação judicial e, por dedução lógica e inarredável, não podem seus titulares participar de qualquer votação na assembléia-geral de credores" (SÉRGIO CAMPINHO. Falência e Recuperação de Empresa... Op. cit., p. 86).

${ }^{540}$ Cf. ERASMo VAlladão França. In: Comentários... Op. cit., p. 2010.

${ }^{541}$ Art. 43. Os sócios do devedor, bem como as sociedades coligadas, controladoras, controladas ou as que tenham sócio ou acionista com participação superior a $10 \%$ (dez por cento) do capital social do devedor ou em que o devedor ou algum de seus sócios detenham participação superior a 10\% (dez por cento) do capital social, poderão participar da assembléia-geral de credores, sem ter direito a voto e não serão considerados para fins de verificação do quorum de instalação e de deliberação. Parágrafo único. $\mathrm{O}$ disposto neste artigo também se aplica ao cônjuge ou parente, consangüíneo ou afim, colateral até o $2^{\circ}$ (segundo) grau, ascendente ou descendente do devedor, de administrador, do sócio controlador, de membro dos conselhos consultivo, fiscal ou semelhantes da sociedade devedora e à sociedade em que quaisquer dessas pessoas exerçam essas funções.
} 
Merece o comentário a situação do Fisco, que não tem direito de voto na AGC realizada durante a recuperação judicial porque, como já se disse, acha-se excluído dos seus efeitos. Já nas assembleias realizadas na falência, o fundamento para excluir-se o direito de voto do Fisco é outro, consistente na impossibilidade de transacionar sem prévia autorização legislativa $^{542}$. Parece-nos, todavia, que essa vedação só o impediria de votar nas matérias que efetivamente implicassem transação, o que não se vê, p. ex., na deliberação sobre a constituição do Comitê de Credores ou na eleição dos seus membros.

Finalmente, não terá direito a voto o credor que não tiver o valor ou as condições originais de pagamento do seu crédito afetados pelo plano de recuperação (LRF, art. $45, \S 3^{\circ}$ ). Nesse caso, porém, a restrição ao direito de voto se dá exclusivamente no tocante à deliberação sobre o plano de recuperação, podendo o credor votar em quaisquer outras matérias.

A situação desses credores e as justificativas para que tenham excluído o direito de voto serão analisadas com mais vagar no item 8.4.

\subsubsection{O direito de protestar}

Por analogia ao art. 130 da Lei das S.A., deve-se admitir que, durante a assembleia, os credores poderão fazer ao presidente do conclave os protestos que entenderem pertinentes.

As possibilidades de protesto são amplas, podendo ser utilizado para: (i) reclamar do descumprimento das formalidades da convocação ou da inobservância do quórum de instalação; (ii) opor-se ao ingresso de pessoa sem legitimação ou à participação de credor sem representação regular; (iii) impugnar a declaração de resultado da deliberação, por não ter sido alcançado o quórum legal; (iv) questionar o voto de credor em conflito de interesse ou mesmo impedido de votar; entre inúmeras outras matérias, que não

\footnotetext{
542 "na assembleia de credores na falência surge uma questão nova, que diz respeito ao crédito tributário. Esse problema não ocorre na recuperação judicial, à qual o crédito tributário não está sujeito, nos termos do art. 187 do CTN, com a redação determinada pela Lei Complementar 118/2005. (...) Assim, não havendo lei expressa, não é possível o fisco participar de assembleia-geral de credores na falência, para concordar com qualquer outra forma de liquidação do ativo além daquelas previstas nos arts. 140 e 142 da Lei 11.101/2005". (Luis Felipe Salomão e Paulo Penalva Santos. Recuperação judicial, extrajudicial e falência... Op. cit., p. 136 e 138).
} 
comportam descrição exaustiva. Além disso, mesmo os credores ou seus representantes que não forem admitidos a participar da assembleia poderão registrar o seu protesto quanto a esse fato.

No que diz respeito a questões eminentemente formais, os protestos serão resolvidos pelo presidente da AGC, sem prejuízo da ulterior revisão da decisão pelo juiz. Por outro lado, versando o protesto sobre matéria de mérito (como, p.ex., a existência de conflito de interesse ou abuso do direito de voto), a decisão deverá ser necessariamente do juiz, cabendo ao presidente do conclave se limitar a registrá-lo em ata.

\subsection{Credores em situação em especial}

A Lei n. 11.101/2005 confere tratamento diferenciado a certos credores, aqui chamados de "credores em situação especial". No intuito de sistematizar a matéria, serão analisados os regimes de cada um deles, enfocando as condições, possibilidades e limitações do exercício dos seguintes direitos: (i) direito de voto, (ii) direito de voz e (iii) direito de presença na Assembléia-Geral de Credores.

\subsubsection{Credor que não teve o valor ou as condições originais de pagamento do seu crédito alterados pelo plano de recuperação}

Dispõe o art. $45, \S 3^{\mathrm{a}}$, da LRF que “o credor não terá direito a voto e não será considerado para fins de verificação de quorum de deliberação se o plano de recuperação judicial não alterar o valor ou as condições originais de pagamento de seu crédito”. Quanto a esse credor, sujeito aos efeitos da recuperação, mas que não teve o valor ou as condições originais de pagamento do seu crédito alterados pelo plano de recuperação, verifica-se o seguinte:

\section{(a) direito de voto}

A lei dispõe que esse credor não terá direito a voto somente na deliberação sobre o plano de recuperação que não tenha alterado o valor ou as condições originais de pagamento do seu crédito. Ou seja: poderá votar em qualquer outra deliberação. 
A doutrina faz acentuada crítica a essa opção legislativa, uma vez que parte do equivocado pressuposto ${ }^{543}$ de que tal credor não teria interesse de se opor ao plano, o que é incorreto na medida em que, mesmo sem alterar as condições originais de pagamento do seu crédito, a aprovação do plano poderá comprometer ou colocar em risco a capacidade do devedor de honrar o avençado ${ }^{544}$.

Assim, concorda-se com PAUlo F. C. SALLES DE TOLEDO ${ }^{545}$ quando afirma que "o ideal seria que todos [os credores] participassem (desde que, evidentemente, todos estivessem sujeitos à recuperação), uma vez que a situação de crise não repercute apenas nos interesses de certos credores, abrangendo, na verdade, todos aqueles que tinham relacionamento negocial com o devedor.”.

Por essa e outras razões, ADALBERTO SIMÃo FILHO ${ }^{546}$ defende que, se o credor referido no art. $45, \S 3^{\circ}$, da LRF demonstrar interesse jurídico, dever-se-á conferir a ele direito de voto:

"Mesmo se se entendesse que o valor de crédito e as condições originais de pagamento fossem mantidas pelo plano, ainda assim, em muitos casos, assistiria um direito ao credor de qualquer classe, principalmente quando o mesmo possuísse garantia real sob determinado bem, afetada de alguma maneira pelo plano apresentado. (...), que poderia não ter sido aprovado se estes credores tivessem votado. Portanto, parece-nos que a melhor interpretação que se faz ao dispositivos em comento [art. $45, \S 3^{\circ}$ ] se dá em caráter restritivo, de modo a possibilitar a votação a todos os credores que demonstrem de alguma forma o seu interesse, mesmo não tendo havido modificação no valor de seu crédito ou nas condições de pagamento."

\footnotetext{
543 “Tal pressuposto é questionável porque, mesmo não sendo atingido diretamente pela proposta em votação, é claro que o credor pode ter o seu direito ameaçado na hipótese de aprovação de um plano inconsistente, que não leve à efetiva recuperação do devedor" (FÁBIO UlHOA COELHO. Comentários... Op. cit., p. 156).

544 "Estão impedidos de votar os credores não atingidos diretamente pelo plano de recuperação, o que pode abarcar classes inteiras, não obstante o plano, sem 'alterar o valor ou as condições originais de pagamento de seus créditos', conforme dispõe o art. $45, \S 3^{\circ}$, possa afetar ou pôr em risco os direitos e interesses do credor, quando, por exemplo, possa estabelecer a alienação de estabelecimento e a venda parcial de bens" (JORGE LOBO. In: Comentários... Op. cit., p. 165).

545 "Recuperação judicial: a principal inovação da Lei de Recuperação de Empresas - LRE". Revista do Advogado, São Paulo, n. 83, set. 2005, p. 103.

546 “Interesses transindividuais...”. Op. cit., p. 42-43.
} 
A despeito da relevância da argumentação, entende-se que tal interpretação implica inaceitável violação da lei vigente, embora sirva para justificar futura revisão por parte do legislador.

Registre-se, por fim, que "se houver mais de um plano em votação, e apenas um deles alterar o direito de determinado credor, ele participa apenas da votação deste e não do outro" (FÁBIO UlHOA COELHO ${ }^{547}$ ).

\section{(b) direito de voz.}

Nas assembleias que versem matéria diversa da aprovação do plano, não há dúvida que esse credor poderá exercer o direito voz, dado lhe ser expressamente conferido o direto de voto. Mas a lei silencia quanto à possibilidade de esse credor participar da assembléia em que for impedido de votar, diferentemente do que faz em relação aos credores referidos no art. 43 da LRF, aos quais expressamente garante o direito de participar do conclave.

Para sustentar a exclusão do direito de voz nessa situação, poder-se-ia invocar o adágio ubi lex voluit dixit, ubi noluit tacuit (“onde a lei quis, determinou; onde não quis, silenciou”). Contudo, à falta de motivo plausível para distinção, há outro brocardo mais apropriado ao caso: Ubi eadem ratio, ibi eadem legis dispositio ("Onde existe a mesma razão fundamental, prevalece a mesma regra de Direito"). ${ }^{548}$ É nesse segundo sentido (concedendo o direito de voz a esse credor, mesmo na deliberação sobre o plano) que têm se manifestado a doutrina ${ }^{549}$ e a jurisprudência.

\footnotetext{
${ }^{547}$ Comentários à Nova Lei de Falências e de Recuperação de Empresas. São Paulo: Saraiva, 2005, p. 112.

${ }^{548}$ Vale lembrar, a propósito, a lição de CARLOS MAXIMILIANO: sobre os brocardos: "Não parece difícil descobrir um adágio para amparar um pensamento, e outro para prestigiar idéia diametralmente oposta" (Hermenêutica... Op. cit., p. 241).

549 "Aos credores excluídos da votação, porém, a lei concede direito de voz (i.e., de participar da discussão das matérias submetidas à deliberação)". (ERASMO VAlladÃo FrANÇA. "Assembléia-geral de credores". Revista do Advogado, São Paulo, n. 83, p. 42-50, set. 2005, p. 46). "De qualquer forma, esses credores, embora não votantes e não considerados para fins de verificação de quórum, poderão participar da assembléia na medida em que sustentam a qualidade de credor" (RONALDO ALVES DE ANDRADE. Comentários... Op. cit., p. 200).
} 


\title{
(c) direito de presença
}

Sendo dado a esse credor o direito de voz em todas as assembléias, evidentemente terá também o direito de comparecer a elas.

\subsubsection{Credores com vinculação societária ou de parentesco com o devedor, seu sócio ou controlador (LRF, art. 43, caput e p. u.)}

O art. 43, caput, da LRF dispõe que:

\begin{abstract}
"os sócios do devedor, bem como as sociedades coligadas, controladoras, controladas ou as que tenham sócio ou acionista com participação superior a $10 \%$ (dez por cento) do capital social do devedor ou em que o devedor ou algum de seus sócios detenham participação superior a $10 \%$ (dez por cento) do capital social, poderão participar da assembléia-geral de credores, sem ter direito a voto e não serão considerados para fins de verificação do quorum de instalação e de deliberação".
\end{abstract}

E o parágrafo único desse mesmo artigo determina que o disposto no caput

\begin{abstract}
"também se aplica ao cônjuge ou parente, consangüíneo ou afim, colateral até o $2^{\circ}$ (segundo) grau, ascendente ou descendente do devedor, de administrador, do sócio controlador, de membro dos conselhos consultivo, fiscal ou semelhantes da sociedade devedora e à sociedade em que quaisquer dessas pessoas exerçam essas funções”.
\end{abstract}

A esses credores aplica-se o seguinte regime jurídico:

\section{(a) direito de voto}

Por expressa disposição legal (LRF, art. 43), esses credores não terão direito de voto em nenhuma assembléia geral, tanto na recuperação judicial quanto na falência, a despeito da matéria da pauta. A lei presume haver um conflito de interesses que os impede de votar (hipótese de impedimento formal). 


\section{(b) direito de voz}

Por expressa disposição legal (LRF, art. 43, caput), esses credores, embora provados do direito de voto, têm permissão para "participar" de todas as assembléias, em razão do que se depreende que terão direito de voz. Vale lembrar que, por ser o art. 43, caput, da LRF, uma norma limitativa de direitos, deve ser interpretado restritivamente, sem ensejar a privação de outros direitos além daqueles expressamente excluídos.

\section{(c) direito de presença}

Sendo garantido a esses credores o direito de exercer o direito de voz nas assembléias, logicamente poderão a ela comparecer. A esse respeito, contudo, ERASMO VALLADÃO FRANÇA ${ }^{550}$ ressalva que as “... as pessoas arroladas no artigo 43 e seu parágrafo único ... somente poderão comparecer à Assembléia desde que sejam, concomitantemente, credoras do devedor", pois ... "seria um absurdo que a Lei assegurasse a participação, em uma assembléia de credores, por exemplo, de centenas de acionistas de uma sociedade anônima, só pelo fato de serem sócios da devedora”.

\subsubsection{Credor retardatário (LRF, art. 10)}

Nos termos do art. 10, caput, da LRF, consideram-se retardatários os credores que habilitaram os seus créditos depois de decorrido o prazo previsto no art. $7^{\circ}, \S 1^{\circ}$, da mesma $1 \mathrm{i}^{551}$. A eles também se aplica um regime especial, no que diz respeito à sua participação na AGC:

\section{(a) direito de voto}

O art. 10, $\S 1^{\circ}$, da LRF estabelece que, no processo de recuperação judicial, os credores retardatários não terão direito a voto em nenhuma das deliberações da assembléia geral, exceção feita aos titulares de créditos trabalhistas (LRF, art. 10, $\S 1^{\circ}$ ). Por outro lado,

\footnotetext{
550 “Assembléia-geral de credores”... Op. cit., p. 45.

${ }^{551}$ Art. $7^{\circ}, \S 1^{\circ}$. Publicado o edital previsto no art. 52, § 1o, ou no parágrafo único do art. 99 desta Lei, os credores terão o prazo de 15 (quinze) dias para apresentar ao administrador judicial suas habilitações ou suas divergências quanto aos créditos relacionados.
} 
o parágrafo segundo desse mesmo artigo ressalva a possibilidade de credores retardatários das Classes II e III votarem nas assembleias realizadas na falência, quando já houver sido homologado o quadro-geral de credores contendo o seu crédito.

FÁBIO UlHOA COELhO ${ }^{552}$ ressalta que, nas assembleias realizadas durante a recuperação judicial, os credores retardatários das Classes II e III não adquirem direito de voto nem mesmo depois de admitido o seu crédito, conforme se depreenderia da interpretação sistemática do art. 10 da LRF. Para ele, "não haveria sentido em prever a ressalva apenas no término do $\S 2^{\circ}$ (em virtude da qual o retardatário na falência adquire o direito de voto após a homologação do QGC) se ela também fosse pertinente à hipótese do $\S 1^{o \text { ”. }}$. Nesse mesmo sentido, corroborando o sentido literal da lei, se posicionam JỗO BOSCO CASCARDO DE GOUVÊA ${ }^{553}$ e JAIRO SADDI ${ }^{554}$.

Existem, todavia, posições contrárias a esse pensamento, admitindo o voto dos credores retardatários. Acertadamente, ADALBERTO SIMÃo FILHO ${ }^{555}$ pondera o seguinte a respeito do tema:

"No que tange à negativa de voto aos titulares de créditos retardatários, não nos afinamos com a corrente interpretativa do art. $10, \S 1^{\circ}$, no sentido de que, taxativamente, os mesmos estariam despidos do direito de voto nas deliberações da Assembléia-Geral. (...) se podem votar, à luz do artigo 39, os arrolados no Quadro Geral de Credores, os constantes da relação do administrador, caso ainda não tenha sido formado o quadro geral e, na falta deste, os figurantes da relação apresentada pelo devedor, por que razão não se entender que o retardatário não possa votar quando o mesmo figura na relação do devedor com crédito certo ou quando o mesmo tenha o seu crédito admitido ou alterado por decisão judicial. Portanto, parece-nos que o artigo $10, \S 2^{\circ}$ da lei deve necessariamente ser interpretado à luz do artigo 39 que, inclusive, lhe faz referência no caput, de modo a se admitir não só a participação do credor retardatário para fins de contagem de quorum, como também a sua votação."

\footnotetext{
${ }^{552}$ Comentários... Op. cit., p. 104.

${ }^{553}$ Recuperação e Falência. Op. cit., p. 94.

554 "na recuperação judicial, os credores atrasados nunca obtêm direito de voto na Assembléia de Credores." (JAIRO SADDI. "Suspensão e invalidação da assembléia geral de credores na nova lei de falências". In: CASTRO, Rodrigo R. Monteiro de; e ARAGÃO, Leandro Santos de (coords.). Direito societário e a nova lei de falências e recuperação de empresas. São Paulo: Quartier Latin, 2006, p. 38).

555 "Interesses transindividuais dos credores nas Assembléias-Gerais...”. Op. cit., p. 43.
} 
De fato, não há justificativa para retirar desses credores o direito de voto quando seu crédito já tenha sido admitido por decisão judicial na data da realização da assembléia. "Parece razoável entender que, nesse caso, por força do disposto no art. 39 da LRE, terão eles direito voto”, afirma PAUlo F. C. SAlles DE TOLEDO ${ }^{556}$, no que é seguido por SÉRGIO CAMPINHO ${ }^{557}$, que destaca a incoerência resultante da interpretação literal dos $\S \S 1^{\circ}$ e $2^{\circ}$ do art. 10 da LRF:

“... prevêem os $\S \S 1^{\circ}$ e $2^{\circ}$, do artigo 10: ‘§ $1^{\circ}$ - Na recuperação judicial, os titulares de créditos retardatários, excetuados os titulares de créditos derivados da relação de trabalho, não terão direito a voto nas deliberações da assembléia-geral de credores'. ' $\$ 2^{\circ}$ - Aplica-se o disposto no $\S 1^{\circ}$ deste artigo ao processo de falência, salvo se, na data da realização da assembléia-geral, já houver sido homologado o quadro-geral de credores contendo o crédito retardatário'. Percebe-se incoerência injustificável entre os preceitos: na falência, o crédito retardatário incluído no quadro geral de credores por ocasião da realização da assembléia poderá render ensejo a voto de seu titular; na recuperação não. Qual a lógica da distinção? Nenhuma, em nossa visão."

\section{(b) direito de voz}

Os credores retardatários possuem, em princípio, os mesmo direitos dos demais credores, exceto aqueles expressamente excluídos pela lei. Assim, como não há nenhuma disposição legal que proíba esses credores de se manifestarem na assembléia geral, deve-se reconhecer-lhes o direito de voz ${ }^{558}$.

\section{(c) direito de presença}

Se os credores retardatários têm direito de se manifestar nas assembléias, haverão de a elas poder comparecer, não suscitando este ponto maiores indagações.

\footnotetext{
${ }^{556}$ In: Comentários... Op. cit., p. 85.

${ }^{557}$ Falência e recuperação de empresa. Rio de Janeiro: Renovar, 2006, p. 85.

558 Cf. PAUlo F. C. SALLES DE TOLEDO: "Na recuperação judicial, os credores retardatários - excetuados os trabalhistas - não terão direito de voto nas assembléias gerais. Poderão até participar desses atos, e mesmo ter direito de voz (que não lhes foi retirado)". (Comentários... Op. cit., p. 85). No mesmo sentido: JoÃo BosCO CASCARDO DE GOUVÊA (Recuperação e Falência... Op. cit., p. 93).
} 


\subsubsection{Credores excluídos dos efeitos da recuperação judicial (LRF, art. $49, \S \S 3^{\circ}$ e $4^{\circ}$ )}

Convém analisar, por fim, a situação dos credores excluídos dos efeitos da recuperação judicial, notadamente daqueles referidos nos parágrafos $3^{\circ}$ e $4^{\circ}$ do art. 49 da $\mathrm{LRF}^{559}$, quais sejam, os credores titulares da posição de proprietário fiduciário de bens móveis ou imóveis, de arrendador mercantil, de proprietário ou promitente vendedor de imóvel cujos respectivos contratos contenham cláusula de irrevogabilidade ou irretratabilidade, inclusive em incorporações imobiliárias, ou de proprietário em contrato de venda com reserva de domínio, bem como ainda os credores titulares de créditos decorrentes de adiantamento a contrato de câmbio para exportação.

\section{(a) direito de voto}

Em princípio, os credores excluídos dos efeitos da recuperação judicial não votam em nenhuma assembleia realizada durante o processo (leia-se: no processo da recuperação judicial, dado que mesmo os credores excluídos dos seus efeitos poderão, em princípio, votar nas assembleias realizadas na falência). Relativamente aos credores referidos nos parágrafos $3^{\circ}$ e $4^{\circ}$ do art. 49 da LRF, há norma expressa nesse sentido (LRF, art. $\left.39, \S 1^{\circ}\right)^{560}$, mas que se estende a todos os demais credores que se encontram na mesma situação, como o Fisco e os titulares de créditos decorrentes de obrigações assumidas no âmbito das câmaras ou prestadoras de serviços de compensação e de liquidação financeira

Porém, uma vez que esses credores tenham aceitado se submeter aos efeitos da recuperação judicial ${ }^{561}$, poderão logicamente participar da assembléia, inclusive com direito a voto $^{562}$, conforme ensina MODESTO CARVALHOSA ${ }^{563}$ :

\footnotetext{
559 quais sejam, os credores titulares da posição de proprietário fiduciário de bens móveis ou imóveis, de arrendador mercantil, de proprietário ou promitente vendedor de imóvel cujos respectivos contratos contenham cláusula de irrevogabilidade ou irretratabilidade, inclusive em incorporações imobiliárias, ou de proprietário em contrato de venda com reserva de domínio, bem como ainda os credores proprietários de créditos decorrentes de adiantamento a contrato de câmbio para exportação.

${ }^{560}$ Art. $39, \S 1^{\text {o }}$. Não terão direito a voto e não serão considerados para fins de verificação do quorum de instalação e de deliberação os titulares de créditos excetuados na forma dos $\S \S 3^{\circ}$ e $4^{\circ}$ do art. 49 desta Lei.

${ }^{561}$ Isso não se aplica ao Fisco.

562 Em sentido contrário, já decidiu o Tribunal de Justiça de São Paulo: "Recuperação Judicial. Credor proprietário fiduciário, assim constituído em alienação fiduciária. Pretensão de participar com direito de voz
} 
“...cumpre salientar que a Lei de Recuperação e Falências, ao mencionar que tais créditos não se submetem à recuperação judicial, não vedou a sua inclusão no plano apresentado pelo devedor. Assim, se houver a anuência desses credores, seus créditos poderão ser incluídos na recuperação e, consequentemente, poderão seus titulares participar da assembléia geral."

A título de curiosidade, vale lembrar que na vigência da Lei $n^{\circ}$ 2.024/1908 e do Decreto $\mathrm{n}^{\mathrm{o}} 5.746 / 209$, os titulares de créditos privilegiados ou com garantia real expressamente excluídos dos efeitos da concordata (art. 113) - tinham direito de comparecer à Assembléia e, se quisessem, poderiam até votar acerca da concessão da concordata, desde que renunciassem às suas garantias $\left(\operatorname{art.} 106, \S 3^{\circ}\right)^{564}$. Aliás, o exercício do voto pelo credor hipotecário implicava a renúncia da garantia.

\section{(b) direito de voz}

Para ERASmo VAlladẽo FrançA ${ }^{565}$, os credores excluídos dos efeitos da recuperação, mesmo recusando a se submeterem ao plano, teriam direito de voz na Assembléia-Geral. Já para Jỗo BosCo CASCARDO DE GOUVÊA ${ }^{566}$, esses credores poderiam assistir ao conclave, mas sem nenhuma interferência.

e voto da Assembléia de Credores, na condição de credor com garantia real, bem como de ser incluído no quadro-geral de credores, na mesma situação. Indeferimento. Inteligência do artigo 49, parágrafo $3^{\circ}$ e do artigo $6^{\circ}$, parágrafo $4^{\circ}$, da Lei $n^{\circ} 11.101 / 2005$. Agravo desprovido. (...) Por tais razões, o agravante não tem o direito de participar das Assembléias de Credores da empresa em recuperação judicial, como também, não tem o direito de integrar o quadro de credores da devedora, pois, sendo proprietário fiduciário dos bens dados em alienação fiduciária, poderá exercer os direitos de proprietário fiduciário, pleiteando a busca e apreensão dos bens alienados, nos precisos termos do Decreto-lei $n^{\circ} 911 / 69$, com a redação que lhe foi dada pela Lei ${ }^{\circ}$ 10.931/2004." (TJSP, Câm. Fal. e Recup., AI no 428.701-4/5-00, rel. Des. Pereira Calças, j. 6.12.2006).

${ }^{563}$ In: Comentários à nova lei de falência... Op. cit., p. 281.

${ }^{564}$ Art. 106. A proposta de concordata, para ser valida e produzir effeitos juridicos, si o pagamento fôr á vista, não será inferior a quarenta por cento e deverá ser acceita por maioria de credores: (...) § $2^{\circ}$ Para formar a maioria exigida para a validade da concordata, não se computarão: (...) $1^{\circ}$, os creditos garantidos por hypotheca, privilegios, penhores, antichése ou direito de retenção; (...). § $3^{\circ}$ Os titulares de creditos referidos no $\S 2^{\circ}$, n. 1 , poderão tomar parte na votação da concordata, computando-se esses creditos no respectivo calculo, se renunciarem ás garantias. O facto de votar importa essa renuncia e sujeita os titulares aos effeitos da concordata. Os effeitos da renuncia cessarão si a concordata não for homologada ou si fôr rescindida, salvo o caso de conluio referido no art. 108, n. 3.

565 “.... seus titulares, muito embora possam comparecer à Assembléia e discutir as matérias submetidas à deliberação (direito de voz), não poderão votá-las.” (In: SOUZA JÚNIOR, Francisco Satiro de; PITOMBO, Antônio Sérgio de Moraes (Coords.). Comentários... Op. cit., p. 210).

566 "A Lei admite que certos credores possam assistir aos trabalhos da Assembléia, mas, para alguns, sem qualquer interferência (credores não sujeitos à recuperação ...)”. (Recuperação... Op. cit., p. 90). 
A razão, neste caso, assiste ao primeiro autor: embora a lei não reconheça expressamente a esses credores o direito de voz, sua participação no conclave tende a colaborar para a obtenção do acordo, pois cria a possibilidade (embora remota) de aceitarem se submeter aos efeitos da recuperação, ou mesmo conceder algum outro benefício ao devedor (p. ex., a dilação de prazo para pagamento). Essa linha de pensar parece mais consentânea com os primados da lei, em especial com o princípio da preservação da empresa.

\section{(c) direito de presença}

FÁBIO UlHOA COELHO ${ }^{567}$ adota posição aparentemente isolada a respeito dos credores excluídos dos efeitos da recuperação, entendendo que eles não têm direito sequer de comparecer à assembléia geral:

"A recuperação atinge, como regra, todos os credores existentes ao tempo da impetração do benefício. Assim, da Assembléia não participa aquele credor cuja obrigação constituiu-se após o dia da distribuição do pedido de recuperação judicial. Também por estarem excluídos dos efeitos da recuperação judicial, não têm assento na Assembléia o fiduciário, o arrendador mercantil ou o negociante de imóvel (como vendedor, compromitente vendedor ou titular de reserva de domínio) se houver cláusula de irrevogabilidade no contrato. Igualmente, os bancos credores por adiantamento aos exportadores (ACC), porque não se sujeitam aos efeitos da recuperação judicial, não têm o direito de participar da reunião. De fato, como esses credores não são minimamente atingidos pela recuperação judicial e podem continuar exercendo seus direitos reais e contratuais nos termos da lei própria, não se justifica legitimá-los à participação no evento."

Não se entrevê, todavia, nenhuma razão de ordem prática para proibir-se o ingresso desses credores no conclave. Pelo contrário: conforme já se expôs, a participação deles parece mais bem atender aos desígnios da legislação concursal, pois tende, ao menos em princípio, a colaborar para a obtenção de um acordo.

${ }^{567}$ Comentários... Op. cit., p. 143, n. 85. 


\section{Deliberação da Assembleia-Geral de Credores}

Já se disse várias vezes que, no regime da Lei $n^{\circ} 11.101 / 205$, as principais decisões quanto à solução para a crise do devedor são cometidas aos seus credores. No mais das vezes, essas decisões são tomadas em assembleia, por meio de deliberações.

O vocábulo deliberação ${ }^{568}$, para nós, tem duplo significado ${ }^{569}$, representando tanto a resolução tomada a partir do voto dos credores, como o mecanismo utilizado para a formação da resolução, também conhecido como método assemblear.

Como resolução, a deliberação consiste no resultado combinado das manifestações de vontade de cada credor (por meio do voto), segundo a regra da maioria aplicável à matéria em votação. ERASMO VALLADÃo FRANÇA chega a dizer que a deliberação corresponderia à "vontade coletiva" da comunhão de credores ${ }^{570}$, à semelhança do que ocorre com as sociedades anônimas, em que as deliberações dos sócios formam e expressam a vontade imputada à companhia ${ }^{571}$.

Nessa acepção, os votos individuais dos credores, proferidos na assembleia segundo as formalidades predispostas na lei, dariam origem a um negócio jurídico unilateral $^{572} 573$, formado pela coincidência de vontades individuais que se fundem para expressar a vontade coletiva dos credores ${ }^{574}$.

\footnotetext{
568 Acerca da etimologia do vocábulo, JAIRO SADDI explica que "o signo deliberar deriva do latim libra (balança), designando ponderar, sopesar, equilibrar. Sendo assim, pode-se concluir que a palavra 'deliberação' traz uma idéia de escolha ponderada, tendo em vista todas as opções postas em discussão" (In: Comentários... Op. cit., p. 286.).

569 “O processo deliberativo é dividido em três momentos: a) deliberação; b) concepção; e c) resolução. No que se refere a essas fases, o Brasil adota a corrente francesa de conceituação da palavra deliberação, englobando apenas o ato final do processo deliberativo, ou seja, a resolução. Por conseguinte, a terminologia brasileira tem a palavra deliberação determinando somente a manifestação da vontade coletiva resultante de todo um processo; ou, metaforicamente, como a fala de um sujeito coletivo. Na necessidade de conceituação das demais fases, a exemplo da transação em si, fala-se em processo deliberativo, pressupostos ou estruturas deliberativas." (JAIRO SADDI. Idem, p. 286.).

570 “A Assembléia é o órgão predisposto pela Lei 11.101 para formar e expressar a vontade coletiva da comunhão de credores, através das suas deliberações. Exerce, assim, poder-função deliberante." (In: Comentários... Op. cit., p. 188).

571 Cf. RICARDO TEPEDINO, a partir das lições de José de Oliveira Ascensão: (Direito das Companhias... Op. cit., p. 944).

572 "Constituindo declarações de vontade tendentes a produzir determinados efeitos jurídicos desejados pelo seu emitente, as deliberações da Assembléia se enquadram na definição clássica de negócio jurídico; como não se destinam diretamente a terceiros (...), conclui-se que são negócios jurídicos unilaterais" (Idem, p. 946). O mesmo autor ressalta, porém, que a natureza jurídica da deliberação é questão deveras controvertida,
} 
ERASMO VALLADÃo FrANÇA relata que a doutrina italiana distingue os atos colegiais dos atos coletivos: nos atos colegiais, as manifestações de vontade (votos) "se fundem em ato de uma só pessoa (a pessoa jurídica)”, como ocorre nas deliberações das assembleias das companhias; nos atos coletivos, ensina COMPARATO ${ }^{575}$, "as várias manifestações de vontade não se fundem em ato de uma só pessoa (jurídica, bem se vê), como ocorre nas deliberações das assembléias de condôminos”. Assim, a doutrina conclui que as deliberações das sociedades anônimas são atos colegiais, porque correspondem à vontade imputada a uma só pessoa (a própria companhia).

Fica a dúvida, porém, se essa mesma construção se aplica à deliberação tomada em Assembleia-Geral de Credores. A se entender que a vontade coletiva dos credores é imputada à massa subjetiva, como fazem os autores que invocam a teoria do órgão para explicar a natureza da AGC, então, por lógica, dever-se-ia concluir que as suas deliberações também constituem atos colegiais. Por outro lado, se se entender que a deliberação não resulta em imputação de vontade a nenhuma pessoa ou unidade (possibilidade que se aventou no item 1 deste Capítulo), então se haveria de concluir tratarse de ato coletivo, não colegial.

É bem se ver que o só fato de as resoluções serem tomadas mediante deliberações - a partir da combinação dos votos individuais dos credores - não permite dizer que consistam em atos colegiais ${ }^{576}$, nem pressupõe, necessariamente, a formação de "vontade coletiva", conforme ensina FRANCESCO GALGANO ${ }^{577}$.

havendo também quem lhe defina como ato jurídico em sentido estrito ou como negócio jurídico plurilateral, entre outros rótulos.

573 Não seria um contrato, na medida em que este obriga os contratantes nos limites das respetivas declarações de vontade, ao passo que, nas deliberações "dá-se a vinculação de todos os membros do colegiado, ou da pessoa jurídica, aos seus efeitos, tenham eles ou não votado favoravelmente ao que foi aprovado pela maioria" (FÁBIO KONDER COMPARATO. "Eleição de diretores em companhia aberta. Validade e eficácia de reuniões do conselho de administração de sociedade anônima. 'Quorum' deliberativo em assembléias gerais de companhia aberta”. In: Direito Empresarial: Estudos e Pareceres. São Paulo: Saraiva, 1990, p. 184).

${ }^{574}$ Cf. Modesto CARvalhosa, "as deliberações sociais são declarações da vontade coletiva da companhia e, nesse sentido, entram na categoria de negócios jurídicos. Trata-se de um negócio jurídico unilateral, formado pela coincidência de vontades individuais que se fundem para expressar a vontade coletiva. Constitui, com efeito, um negócio unitário, porque emana de um colégio também unitário." (Comentários à Lei de Sociedades Anônimas... Op. cit., v. 2, p. 609).

575 "Da imprescritibilidade da ação direta de nulidade de norma estatutária”. In: Novos Ensaios e Pareceres de Direito Empresarial. Rio de Janeiro: Forense, 1981, p. 216.

${ }^{576}$ Existem razões mais que suficientes para excluir a vigência, no nosso sistema, de um princípio geral que imponha a formação colegial das deliberações. O método colegial se refere ao modo de funcionamento de 
"Resulta carente de base normativa a teoria tradicional que qualifica a deliberação como ato colegial, expressão de uma vontade coletiva, e a contrapõe tanto ao contrato quanto ao ato unilateral. A colegialidade se refere às internas e variadas formas de organização dos entes coletivos; a deliberação, separada do procedimento - às vezes livre, às vezes vinculado a uma modalidade rigorosa - segundo o qual é formada, não consiste senão na pluralidade dos votos que concorrem para formá-la".

E a própria ideia "comunhão de credores", embora prevalente, também não conta com a adesão unânime da doutrina, valendo anotar a crítica sempre oportuna de TRAJANO DE MiRANDA VALVERDE ${ }^{578}$ :

"O concurso de credores é um processo legal. Não é possível ver-se nessa concorrência uma associação, embora momentânea, de indivíduos, ou mesmo uma communio incidens, ou qualquer outra espécie de comunhão. (É um termo que também deve ser afastado por gerar ideias erradas sobre o concurso de credores). Cada credor, que no concurso resolve entrar, sabe de antemão quais são os seus direitos e quais as suas obrigações; o que pode e o que não pode fazer. Cada um age por si e no seu próprio interesse, contrariando, se possível, o dos outros concorrentes. Nenhum espírito associativo, mas o conflito de interesses, que a lei procura solucionar, ora pondo de lado os interessados, ora consultando-os pela voz da maioria".

De qualquer forma, seja entendida como expressão da "vontade coletiva" ou da vontade presumida da maioria ${ }^{579}$, certo é que a formação da deliberação obedece a um processo de natureza jurídica. Para que ela exista, é necessário um procedimento que organize os atos dos participantes, o qual vem a ser denominado método assemblear.

determinadas organizações coletivas e, em primeiro lugar, das sociedades capitalistas; não diz respeito ao modo de expressar determinados atos jurídicos, como o voto e a deliberação (FRANCESCO GALGANO. Trattato di diritto civile. Milão: Cedam, 2010, v. 3, p. 30, tradução livre). No original: "esistono elementi di giudizio piú che sufficienti per escludere la vigenza, nel nostro sistema, di un generale principio che impogna la formazione collegiale delle deliberazioni. Il metodo collegiale attiene al modo di operare di determinate organizzazioni collettive e, in primo luogo, delle società di capitali; non attiene al modo di espressione di determinati atti giuridici, quali il voto e la deliberazione”.

${ }^{577}$ Trattato di diritto civile... Op. cit., v. 3, p. 30, tradução livre. No original: "risulta priva di basi normative la tradizionale teoria che qualifica la deliberazione come atto collegiale, esprimente una volontà collettiva, e la contrappone tanto al contratto quanto all'atto unilaterale. La collegialità attiene alle interne e varie forme di organizzazione degli enti collettivi; la deliberazione, separata dai procedimenti - a volte liberti, a volte vinvolati a modalità rigorose - secondo i quali è formata, in altro non consiste se non nella pluralità dei voti che concorrono a formala".

${ }^{578}$ A Fallencia no Direito Brasileiro. Rio de Janeiro: Ariel, 1931, v. 1, p. 146.

579 “A assembléia de credores, isto é, os credores reunidos em determinadas condições, dá-lhes a lei atribuições, que eles as exercem consoante as prescrições da própria lei, delas não podendo afastar-se nas deliberações que tomarem, as quais, como em todas as assembléias, exprimem a vontade presumida da maioria" (Trajano de Miranda VAlVERdE. A Falencia... Op. cit., v. 2, p. 47). 
O método assemblear estrutura a sucessão de eventos que culminará na proclamação da resolução, desde a prévia convocação da assembleia, com a indicação da ordem do dia, até o cumprimento das formalidades durante o conclave ${ }^{580}$, conforme explica ÁlVARO MARIANO ${ }^{581}$ :

"Em linhas muito gerais, esse procedimento estrutura-se segundo a seguinte ordem de acontecimentos: uma vez composta a mesa diretora, verificada a presença do quorum necessário de acionistas (quórum de instalação) e instalada a assembleia, é feita a apresentação da proposta objeto da deliberação (cuja matéria, como regra, deve ter constado da 'ordem do dia', isto é, a relação de temas passíveis de deliberação na assembleia e que deve integrar o instrumento convocatório do conclave), a que se seguem o estabelecimento dos debates (o contraditório), a manifestação dos votos e, por fim, a apuração e proclamação do respectivo resultado, conforme o quórum necessário (quorum de deliberação)".

Destina-se tal procedimento, em primeiro lugar, a possibilitar o contraditório entre os participantes ${ }^{582}$, como forma de proteção da minoria $^{583}$, a fim de que, previamente à votação, possam defender as suas posições e tentar convencer a maioria do acerto de determinadas decisões ou da inconveniência de outras. A assembleia não é simples meio de consulta, como ocorre com o voto por correspondência, mas o instrumento com que conta o credor para confrontar a sua opinião com os demais ${ }^{584}$ :

\footnotetext{
${ }^{580}$ Cf. ERASMO VAlladão França. Invalidade das deliberações... Op. cit., p. 37.

${ }^{581}$ Cf. ÁlVARO MARIANO: Abuso de voto na recuperação judicial... Op. cit., p. 153.

${ }^{582}$ Vale lembrar que, no âmbito da recuperação extrajudicial, o acordo firmado com a maioria dos credores vincula os demais, dispensando-se a realização de assembleia e, por conseguinte, de debates entre os credores interessados (LRF, arts. 163 e 164).

583 Cf. Francesco Galgano, "O método assemblear funciona como um instrumento de proteção da minoria: permite que eles sejam previamente informados do objeto da deliberação, participem da discussão que preceda à votação e, nela, em contraditório com a maioria, defender o próprio ponto de vista. Mas a deliberação, quando tomada em uma assembleia regularmente convocada e com o contraditório entre a maioria e a minoria, prevalece sempre a vontade da maioria, vinculante sobre a minoria" (Trattato di diritto civile... Op. cit., v. 3, p. 28). No original: "Il metodo assembleare opera come strumento di protezione delle minoranze: permete loro di essere previamente informate dell'oggetto delle deliberazioni, di partecipare ad una discussione che preceda la votazione e nel corso della quale difendere, in contraddittorio con la maggioranza, il proprio punto di vista. Ma la deliberazione, per quanto presa in una assemblea regolarmente convocata e nel contraddittorio fra maggioranza e minoranza, resta pur sempre volontà della maggioranza, vincolante anche per la minoranza".
}

${ }^{584}$ Cf. Modesto Carvalhosa. Comentários à Lei de Sociedades Anônimas... Op. cit., p. 603. 
"É, com efeito, na assembléia geral que pode ocorrer troca de pontos de vista e, assim, a intervenção minoritária. Esta tem seu peso nas decisões, na medida em que, ao arguir as questões propostas, não se considera a sua participação no capital, mas, principalmente, o seu poder de persuasão e a justeza de seus argumentos. Insista-se no aspectos ideal desses fundamentos" (MODESTO CARVALHOSA ${ }^{585}$ ).

\begin{abstract}
Além disso - afirma ERASMO VALLADÃo FrANÇA ${ }^{586}$-, "há outra razão, mais profunda ainda, a impor a obrigatoriedade do método assemblear”, consistente na vinculação de todos, dissidentes ou ausentes, às resoluções tomadas na assembleia: “como obtempera Comparato, 'seria, com efeito, aberrante que todos os componentes do collegium (ou a pessoa jurídica na qual este se insere como órgão) ficassem vinculados por declarações coletivas de vontade às quais não tiveram acesso,”.
\end{abstract}

Daí por que a observância do método assemblear constitui condição de validade da deliberação ${ }^{587}$.

\title{
9.1. Quóruns de deliberação
}

As deliberações da Assembleia-Geral de Credores obedecem ao chamado princípio majoritário $^{588}$, que determina a vinculação de todos, inclusive dos dissidentes ou ausentes $^{589}$, à decisão sufragada pela maioria dos credores, desde que respeitados os quóruns mínimos legais pertinentes a cada matéria em votação.

A adoção do princípio da maioria se justifica, em primeiro lugar, em razão da impossibilidade prática de obter-se a unanimidade ${ }^{590}$, sobretudo num grupo de pessoas

\footnotetext{
${ }^{585}$ Idem.

${ }^{586}$ Invalidade das deliberações... Op. cit., p. 39.

${ }^{587}$ Cf. ERASMO VAlladẽo FranÇA, com amparo nas lições de Galgano e de José Luiz Bulhões Pedreira (Idem, p. 37-38).

${ }^{588}$ Cf. JORGE LOBO, “o princípio majoritário, surgido no direito medieval, baseia-se na idéia de que quod maior pars facit, totum facere videtu e, expressa, no dizer de Gierke, nas decisões em colegiado, a 'equiparação da maioria à totalidade' (In: Comentários... Op. cit., p. 161).

589 “Esse princípio majoritário é da essência das decisões societárias, pois a unanimidade, como regra, inviabilizaria o funcionamento das sociedades, conforme dão conta as legislações europeias e norteamericanas" (LuIS FEliPE SALOMÃo e PAUlO PENALVA SANTOS. Recuperação judicial... Op. cit., p. 142).

${ }^{590}$ Aplica-se aqui o mesmo que ocorre nas sociedades: "quando se transpõe a questão para um grupo de pessoas estranhas, que são convocadas, em número ilimitado, para participarem da mesma sociedade, ela se
} 
estranhas, com interesses nem sempre convergentes ${ }^{591}$. Em segundo lugar, presume-se que a decisão sufragada pela maioria tende a gozar de maior legitimidade ${ }^{592}$, além de se supor mais justo cometer-se a decisão àqueles que, por possuírem os maiores créditos, sujeitamse a um risco também maior.

Assim é que, para a aprovação das matérias postas em votação, requer-se a manifestação de alguma maioria, que tanto poderia ser maioria simples dos presentes ou uma maioria qualificada, a depender do objeto da deliberação. Note-se ainda que, diferentemente do Decreto-Lei no 7.661/45, a Lei no 11.101/2005, não previu critério de desempate $^{593}$, de modo que, não alcançada a maioria, entende-se rejeitada a proposta em votação.

\subsubsection{Quórum geral}

Como regra geral, considerar-se-á aprovada a proposta que obtiver votos favoráveis de credores que representem mais da metade do valor total dos créditos presentes à Assembléia-Geral, independentemente da sua natureza ou classificação 594 (LRF, art. 42, caput).

torna de extrema complexidade, submetendo-se à lei geral "da impossibilidade das escolhas unânimes", (José Luiz Bulhões Pedreira e Alfredo LAMy Filho. A Lei das S.A. 3 ed. Rio de Janeiro: Renovar, 1997, v. 1, p. 153).

591 “A importância da disciplina das assembléias gerais reside no fato de que deliberações colegiadas tomadas de acordo com as normas previstas vinculam todos os membros do grupo, inclusive os ausentes ou dissidentes, porque o princípio informador das assembléias gerais, o da maioria - que excepciona a unanimidade -, tendo como limite objetivo direitos individuais, atende melhor que a unanimidade ao equacionamento de situação em que interesses diversos estão em jogo" (RACHEL SZTAJN. "Notas sobre as assembléias de credores na lei de recuperação de empresas". RDM, São Paulo, n. 138, p. 157).

592 “a idéia que está na base do princípio majoritário, observou Kelsen, é a de que o ordenamento social deve estar de acordo com o maior número possível de sujeitos, e em desacordo com o menor número possível" (FÁBIO KONDER COMPARATO. O poder de controle na sociedade anônima. 3 ed. Rio de Janeiro: Forense, 1983, p. 43).

${ }^{593} \mathrm{O}$ art. $122, \S 3^{\circ}$, do Decreto-Lei $\mathrm{n}^{\mathrm{o}} 7.661 / 45$ previa que, em casos de empate, prevaleceria a decisão sufragada pelo maior número de credores, solução que ERASMO VALLADÃo FRANÇA reputa "esdrúxula" (In: Comentários... Op. cit., p. 213).

${ }^{594} \mathrm{Na}$ votação das matérias sujeitas ao quórum geral, portanto, "não se computam os créditos de acordo com cada classe, como ocorre com o quórum de instalação (v. art. 37, § $2^{\circ}$ )" (ERASMO VALladÃo FranÇA. In: Comentários... Op. cit., p. 213). 
Trata-se do chamado quórum geral de deliberação das matérias de competência do Plenário, as quais são definidas por exclusão, compreendendo todas aquelas cuja decisão não é cometida às classes de credores. Aqui os votos são computados exclusivamente segundo o valor do crédito presente à assembléia (não importando o número de credores que tenha sufragado a proposta).

$\mathrm{Na}$ recuperação judicial, submetem-se ao quórum geral de deliberação as matérias referidas nas alíneas "d", "e" e "f" do inciso I do art. 35 da LRF, compreendendo a apreciação do pedido de desistência do devedor, a escolha do gestor judicial (em caso de afastamento do devedor) e quaisquer outras matérias que possam afetar os interesses dos credores. Além disso, por conta da remissão feita pelo art. 73, I, da $\operatorname{LRF}^{595}$ ao art. 42 da mesma lei, entende-se que a aprovação da quebra do devedor (que ensejará a convocação da recuperação judicial em falência) também se submete à decisão dos credores que representem mais da metade do valor total dos créditos presentes à assembléia-geral, independentemente da classe que integrem ${ }^{596}$.

Tem-se assim que, enquanto a deliberação sobre a quebra é de competência do Plenário, sujeitando-se ao quórum geral da maioria do valor total dos créditos presentes, comete-se às classes de credores a decisão sobre a aprovação do plano de recuperação, sujeita a quórum especial de deliberação (aprovação nas três classes, por valor do crédito e por cabeça nas Classes II e III, e só por cabeça na Classe I, composta pelos credores trabalhistas).

Sabendo-se que a rejeição do plano implicará a decretação da falência, percebe-se certa incongruência legislativa na definição de competências e quóruns distintos para a aprovação do plano e da quebra. Porque da forma como foi estabelecido é teoricamente possível que, numa mesma assembleia, a que compareçam os mesmo credores, seja tanto possível aprovar o plano quanto a quebra.

\footnotetext{
595 Art. 73. O juiz decretará a falência durante o processo de recuperação judicial: I - por deliberação da assembléia-geral de credores, na forma do art. 42 desta Lei.

${ }^{596}$ Cf. Moema Augusta SoAres de CASTro. In: CORRÊA-LIMA, Osmar Brina; e LIMA, Sérgio Mourão Correa (coord.). Comentários à nova Lei de Falência e Recuperação de Empresa. Rio de Janeiro: Forense, 2009, p. 482. No mesmo sentido, confira-se CARLOS KlEIN ZANINI. In: Comentários... Op. cit., p. 326.
} 
Imagine-se caso em que Classe I conte com 100 empregados cujos créditos totalizam $§ 1000$, sendo que um dos empregados ("A") titulariza sozinho um crédito de $\$ 900$, enquanto que os créditos somados das duas outras classes não passam de $\$ 500$. Nesse cenário, supondo-se que todos os credores, à exceção de “A”, votem a favor da aprovação do plano, a recuperação judicial haverá de ser concedida, já que o valor do crédito trabalhista é irrelevante na Classe I, para fins de deliberação do plano segundo o quórum ordinário previsto no art. 45. Por outro lado, posta em discussão a proposta de quebra, o voto favorável de "A", por si só, seria suficiente para a aprovação da medida, ensejando a convolação da recuperação judicial em falência.

Sabe-se que a hipótese aventada é rara, mas nem por isso deixa de causar perplexidade.

\subsubsection{Quórum especial - aprovação do plano de recuperação}

A proposta de aprovação ou modificação do plano de recuperação judicial, como já se disse, é deliberada pelas classes de credores, segundo a divisão estabelecida pelo art. 41 da LRF. Cuida-se de matéria sujeita a quórum especial, cuja aprovação depende da obtenção da maioria em todas as classes, consoante dispõe o art. 45, caput, da LRF: "Nas deliberações sobre o plano de recuperação judicial, todas as classes de credores referidas no art. 41 desta Lei deverão aprovar a proposta”.

Nessa deliberação, os votos dos credores da Classe I, composta pelos credores trabalhistas, são computados por cabeça, independentemente do valor do crédito. Assim, nessa classe, considera-se aprovada a proposta relativa ao plano de recuperação quando obtidos os votos favoráveis de mais da metade dos credores presentes (LRF, art. $45^{\circ}, \S 2^{\circ}$ ). Por outro lado, nas Classes II e III, a proposta deverá ser aprovada por credores que representem mais da metade do valor total dos créditos presentes à assembléia e, cumulativamente, pela maioria simples dos credores presentes (LRF, art. $45, \S 1^{\circ}$ ).

Na deliberação sobre a aprovação do plano de recuperação, caso não seja alcançada a maioria em apenas uma das classes, segundo os critérios acima explicados, ainda assim a proposta se reputará aprovada pela Assembleia se (i) ao menos duas das classes de credores tenham aprovado o plano, (ii) tenha sido obtido o voto favorável de 
credores que representem mais da metade do valor de todos os créditos presentes à assembleia, independentemente de classes; e (iii) na classe que houver rejeitado a proposta, mais de 1/3 (um terço) dos credores tenham votado favoravelmente (LRF, art. 58, $\S 1^{\circ}$ ). Cuida-se, pois, de quórum alternativo de aprovação do plano, apelidado de "cram down", em referência ao instituto previsto no Bankruptcy Code norte-americano.

\subsubsection{Quórum especial - constituição do Comitê de Credores}

A constituição do Comitê de Credores também se sujeita a quórum especial, podendo ser aprovada por deliberação da maioria de qualquer classe (LRF, art. 26). Assim, basta que uma das classes aprove a criação do Comitê, para que ele seja constituído, ainda que as demais classes tenham desaprovado a matéria. Além disso, compete a cada classe, também por maioria, escolher o seu representante.

Vale notar, porém, que a divisão das classes para a deliberação dessa matéria não obedece à regra geral estabelecida no art. 41 da LRF. Conforme já explicado no item deste Capítulo, aqui os credores com privilégio especial compõem a Classe II, juntamente com os titulares de créditos com garantia real, e não mais a Classe III, como ordinariamente ocorre.

Diferentemente do que se passa na deliberação sobre o plano de recuperação, o a cálculo da maioria nas três classes leva em conta apenas o valor dos créditos presentes à assembleia, sendo indiferente o número de credores que tenham aprovado a proposta.

\subsubsection{Quórum especial - aprovação de forma alternativa de liquidação}

A aprovação de forma alternativa de realização do ativo do devedor na falência (prevista no art. 145 desta Lei) dependerá do voto favorável de credores que representem $2 / 3$ (dois terços) dos créditos presentes à assembléia, independentemente de classes ${ }^{597}$ (LRF, art. 46). Essa matéria, portanto, é de competência do Plenário, computando-se os votos proporcionalmente ao valor do crédito (não há voto "por cabeça”).

597 “O quorum será de dois terços dos créditos presentes à assembléia-geral, ressalte-se, independentemente de classe” (MARIO SERGIO MiLANI. Lei de recuperação judicial... Op. cit., p. 197). 


\subsection{A deliberação sobre o plano de recuperação}

Caso algum credor tenha, tempestivamente, oferecido objeção ao plano de recuperação, o juiz convocará a Assembléia-Geral de Credores para deliberar sobre o plano de recuperação (LRF, art. 56). Como já se disse, cuida-se da sua competência mais relevante, sintetiza a prerrogativa conferida aos credores soberania para decidir sobre a solução a ser dada à insolvência do devedor comum.

A respeito do tema, reporta-se aos comentários feitos no item 4.1.1 deste Capítulo, acrescentando-se apenas que, por força do art. 56, $\S 1^{\circ}$, da LRF, a AssembleiaGeral para a deliberação sobre o plano deverá ocorrer em 150 dias contados do deferimento do processamento da recuperação judicial.

Não há sanção para o descumprimento desse prazo, como, p. ex., a decretação da falência. Na verdade, como bem ponderado por EDUARDO SECCHI MUNHOZ ${ }^{598}$, cuida-se de previsão relacionada com o prazo improrrogável de suspensão das ações e execuções contra o devedor previsto no art. $6^{\circ}, \S 4^{\circ}$, da LRF, que é de 180 dias. A intenção do legislador, portanto, é que a AGC seja realizada durante o período de fôlego concedido ao devedor, para que se evite o comprometimento da negociação por conta da ação individual de algum credor.

\subsection{1. "Cram down" - críticas ao modelo brasileiro}

O art. 58 da LRF prevê que o juiz concederá a recuperação judicial cujo plano não tenha sofrido objeção dos credores, ou tenha sido aprovado na assembleia-geral de que trata o art. 45 da mesma lei, por maioria de votos de todas as classes de credores.

Entretanto, não se logrando obter a aprovação de uma das três classes de credores, dispõe o art. $58, \S \S 1^{\circ}$ e $2^{\circ}$, da LRF que o juiz poderá conceder a recuperação judicial desde que (i) as demais classes de credores tenham aprovado o plano, (ii) a soma dos créditos daqueles que votaram favoravelmente ao plano represente mais da metade do valor de todos os créditos presentes à assembleia, independentemente de classe; (iii) na

${ }^{598}$ In: Comentários... Op. cit., p. 271-275. 
classe que o houver rejeitado, mais de 1/3 (um terço) dos credores tenham votado favoravelmente; e (iv) o plano não implique tratamento diferenciado entre os credores da classe que o houver rejeitado.

A essa possibilidade de o juiz impor o plano de recuperação a determinada classe de credores dissidentes, dá-se o nome de "cram down" previsto no "Chapter 11" do "Bankruptcy Code" norte-americano (\$1.129). Cuida-se, em síntese, de mecanismo de controle judicial que, além de propiciar a preservação da empresa, presta-se a superar a oposição considerada ilegítima.

O "cram down" norte-americano, todavia, é bastante diferente do brasileiro.

Nos Estados Unidos, o juiz pode conceder a recuperação sempre que o plano rejeitado seja (i) viável ("feasible"), isto é, que seja efetivamente capaz, do ponto de vista econômico-financeiro, de permitir a superação da crise do devedor e o pagamento dos credores da força convencionada; (ii) justo e equitativo ("fair and equitable"), o que significa estrita obediência à ordem de preferência legal (nenhum credor de classe inferior pode receber antes de pagarem-se todos os credores que integram classe superior na ordem de preferência); e (iii) não implique tratamento diferenciado entre os credores de uma mesma classe ou entre classes de mesma hierarquia ("unfair discrimination"). Além disso, a recuperação não poderá ser deferida se o plano sujeitar os credores a condições piores do que as previstas em caso de liquidação, salvo se quem vier a ser prejudicado aceitar o plano nessas condições.

Há um equilíbrio no sistema americano, que privilegia a preservação da empresa, mas sem descuidar dos direitos e interesses legítimos dos credores, mesmo no “cram down”. Além disso, confere-se ao juiz mecanismo efetivo para superar os impasses e intransigências que se lhe apresentam contrários aos princípios a serem privilegiados no caso concreto da crise da empresa.

\footnotetext{
${ }^{599}$ Sobre a origem da expressão "cram down", CHARLES JORDAN TABB esclarece: "Confirmation of a plan over a class dissent is known as cram down of the plan, because the plan is 'crammed down' the throat of the dissenting class" (The Law of Bankruptcy. Nova Iorque: The Foundation Press, 1997, p. 829). Em vernáculo, a expressão poderia ser traduzida como "forçar goela abaixo" (não muito consentânea, é verdade, com a tradição do nosso direito).
} 
No Brasil, o juiz não tem a mesma discricionariedade. Conforme AlBERTO CAMIÑA MOREIRA ${ }^{600}$, “o cram down brasileiro é legalista, fechado e não dá margem ao juiz para a imposição de plano que possa recuperar a empresa a despeito da discordância dos credores".

No mesmo sentido, o EDUARDO SECCHI MUNHOz ${ }^{601}$ afirma que o "cram down" brasileiro "não depende de fatores relacionados com a efetiva possibilidade de recuperação da empresa”, mantendo o poder de decisão com a assembleia-geral de credores. Configura, pois, nada mais do que "um quórum alternativo de aprovação do plano”, pois não faculta ao juiz a apreciação concreta da situação econômico-financeira do devedor.

Assim, mesmo que a empresa recuperanda seja economicamente viável, e a despeito da relevância da sua função social, não pode o juiz, segundo a estreita redação da nossa lei, conceder a recuperação se a ela se opuserem os credores. Privilegia-se, pois, o seu interesse individual em prejuízo da preservação da empresa, contrariando-se a própria natureza finalidade do instituto do "cram down"602.

Além disso, à falta de mecanismo que permita a imposição forçada de um plano viável e justo, compromete-se o equilíbrio que deveria haver na negociação entre credores e devedor, bem como a própria eficiência do sistema. A lógica da "negociação estruturada", segundo o bem-sucedido modelo americano, depende justamente da consciência dos participantes de que, se não chegarem a um acordo ou se forçarem exageradamente suas posições, o poder de decisão sairá das suas mãos e passará ao juiz. Sem isso, prevalece pura e simplesmente a lei do mais forte, impondo-se a todos a vontade de quem pode mais, o que nem sempre resulta em soluções legítimas.

\footnotetext{
600 In: PAIVA, Luiz Fernando Valente de (coord.). Direito falimentar e a nova Lei de Falências e Recuperação de Empresas. São Paulo: Quartier Latin, 2005, p. 259.

${ }^{601}$ In: Comentários... Op. cit., p. 286.

${ }^{602}$ Não é o que se passa em outras legislações que adotam o "cram down". Do mesmo modo que ocorre no sistema norte-americano, já referido, a legislação concursal argentina, desde o advento da Lei $n^{\circ}$ 25.589/2002, também confere ao juiz a possibilidade de superar o voto desfavorável dos credores. Assim, poderá homologar o acordo preventivo, caso entenda que a preservação da empresa, além de viável, mais bem atende aos interesses coletivos, mas desde que esse acordo não enseje abuso ou fraude.
} 
Vale lembrar ainda que, preenchidos os requisitos constantes do art. $58, \S \S 1^{\circ} \mathrm{e}$ $2^{\circ}$, da LRF (obtenção do quórum alternativo e ausência de tratamento diferenciado entre credores da mesma classe), dispõe a lei que o juiz "poderá" (e não "deverá”) conceder a recuperação, o que permitiria argumentar, a partir de interpretação literal, que a concessão da recuperação, nesses casos, seria mera faculdade do juiz ${ }^{603}$, não uma obrigação.

Essa não parece ser, todavia, a melhor exegese, pois as pretensas "faculdades" do juiz constituem, na verdade, um "poder-dever", que obriga o magistrado a agir de determinada maneira se verificadas certas circunstâncias. E como a lei só veda o "cram down" na hipótese de o plano implicar tratamento diferenciado entre os credores da classe que o houver rejeitado (nem mesmo cogita da necessidade de obedecer-se à ordem legal de pagamento dos credores), conclui-se que, se o plano não incidir nessa proibição específica, a recuperação deverá ser obrigatoriamente concedida, dado que a lei não prevê outras razões para que o juiz a indefira ${ }^{604}$.

À vista de tudo isso, conclui-se que o legislador pátrio não tratou adequadamente do instituto "cram down" outras formas de controle das deliberações da assembleia-geral de credores, sobretudo mediante o exame da validade dos votos nela proferidos, inclusive para apurar eventual abuso $^{606}$ cometido por determinado credor.

\footnotetext{
${ }^{603}$ É o que defende SILVÂNIO COVAS, para quem o parágrafo $1^{\circ}$ do art. 58 “traduz-se em opção discricionária, conferida ao prudente arbítrio do juiz" (In: Comentários... Op. cit., p. 306).

${ }^{604}$ Nesse sentido, entre outros, confira-se SÉRGIO CAMPINHO: "Verificadas todas essas condições, a recuperação deverá ser concedida pelo magistrado. O vocábulo 'poderá' empregado no texto legal $\left(\S 1^{\circ}\right.$, do artigo 58) não quer traduzir uma faculdade do juiz, mas um poder-dever." (Falência e recuperação de empresa... Op. cit., p. 84). Assim também tem se posicionado a jurisprudência (TJSP, Câm. Fal. e Recup., AI no 561.271-4/2-00, rel. Des. Pereira Calças, j. 30.7.2008; citado por CRISTIANO IMHOF. Lei de recuperação de empresas e falência... Op. cit., p. 302).

${ }^{605}$ Está em tramitação no Congresso Nacional projeto de lei, de autoria do Senador Valdir Raupp de Matos, que visa à alteração da LRF, de modo a ampliar os poderes do juiz no exercício do "cram down" (Projeto de Lei do Senado n. ${ }^{\circ}$ 391/2009).

${ }^{606} \mathrm{O}$ abuso de direito, nos termos do art. 187 do Código Civil, também configura ato ilícito.
} 


\subsection{Validade das deliberações}

A validade das deliberações da AGC depende do atendimento das formalidades previstas para a realização do conclave ${ }^{607}$, bem como das normas que limitam e condicionam as resoluções tomadas.

Assim, será inválida a deliberação que contrarie a lei ou que vise a fraudá-la (como, p. ex., no caso de deliberação que aprove plano de recuperação prevendo o pagamento dos credores trabalhistas em prazo superior a um ano, o que é terminantemente vedado pelo art. 54 da $\mathrm{LRF}^{608}$ ).

Além disso, a validade das deliberações depende, em regra, da validade dos votos nela proferidos, de sorte que o vício que contamina a manifestação de vontade de determinado credor poderá, em determinadas circunstâncias, ensejar a invalidade da própria deliberação.

É o caso, p. ex., do voto abusivo, isto é, daquele voto que excede os limites impostos pelo seu fím econômico ou social, pela boa-fé ou pelos bons costumes. Verificando abuso, o juiz poderá declarar o voto nulo e inválida a deliberação, ou ainda, dependendo da matéria e da circunstância, proclamar resultado diverso daquele originalmente obtido.

Nem sempre o voto inválido ensejará a invalidade da deliberação, notadamente quando o desconto desse voto não for capaz de alterar a resolução tomada. Ou seja, se for obtido o quórum de deliberação a despeito do voto inválido, a invalidade do voto não resultará na da deliberação, por aplicação dos arts. 170 e 184 do Código Civil ${ }^{609}$.

\footnotetext{
${ }^{607}$ A invalidade da própria assembleia, p. ex., no caso de irregularidade da convocação ou da sua instalação, ensejará a invalidade das deliberações nelas tomadas.

${ }^{608}$ Art. 54. O plano de recuperação judicial não poderá prever prazo superior a 1 (um) ano para pagamento dos créditos derivados da legislação do trabalho ou decorrentes de acidentes de trabalho vencidos até a data do pedido de recuperação judicial.

${ }^{609}$ Art. 170. Se, porém, o negócio jurídico nulo contiver os requisitos de outro, subsistirá este quando o fim a que visavam as partes permitir supor que o teriam querido, se houvessem previsto a nulidade.

Art. 184. Respeitada a intenção das partes, a invalidade parcial de um negócio jurídico não o prejudicará na parte válida, se esta for separável; a invalidade da obrigação principal implica a das obrigações acessórias, mas a destas não induz a da obrigação principal.
} 
É o que a doutrina italiana chama de prova di resistenza, que se presta a verificar justamente se a deliberação resiste mesmo se desconsiderado determinado voto ${ }^{610}$.

Ressalva-se, ainda, que, por opção legislativa, as deliberações da assembléiageral não serão invalidadas em razão de posterior decisão judicial acerca da existência, quantificação ou classificação de créditos (LRF, art. 39, § $2^{\circ}$ ).

Como se sabe, são admitidos à assembleia aqueles credores que tenham essa condição reconhecida segundo a fase do processo (LRF, art. 39, caput), sendo possível que, depois da realização do conclave, ocorra alteração da composição da massa subjetiva, como para admitir novos credores, excluir outros, ou ainda alterar o valor ou a classificação dos créditos. Em tese, tais alterações poderiam ter impacto sobre o resultado da votação (como no caso de determinada deliberação ter sido aprovada ou rejeitada pelo voto de quem teve o crédito excluído a posteriori).

Por essa razão, alguns doutrinadores têm taxado o art. $39, \S 2^{\circ}$, de inconstitucional $^{611}$, ao passo que outros entendem que o direito individual daqueles porventura prejudicados pela norma deve ceder em face do princípio da segurança jurídica, como pondera FÁBIO KONDER COMPARATO ${ }^{612}$ : “Essa determinação da lei visa a conferir segurança às deliberações assembleares. Se tais decisões pudessem interferir no resultado das assembleias passadas, o processo de recuperação judicial estaria exposto a significativos entraves”.

Os partidários dessa segunda corrente justificam que, em não sendo possível, em termos práticos, aguardar-se a constituição definitiva do quadro-geral de credores para só então realizar a assembleia ${ }^{613}$, é razoável e aceitável admitir que a deliberação seja tomada por aqueles aparentam a condição de credores no dia da realização do conclave. Cuidar-se-ia de hipótese de ponderação de princípios, tendo o legislador optado por

\footnotetext{
${ }^{610}$ Cf. Alfredo SÉrgio LAZZARESChi Neto, com base nas lições de Ferrara e Corsi in "Gli imprenditori e le società”. 12 ed. Milão: Giuffrè, 2001, p. 499 (Lei das Sociedades por Ações anotada... Op. cit., p. 823).

${ }^{611}$ Nesse sentido, assim se manifesta MODESTO CARVALHOSA: "privar as partes envolvidas da possibilidade de levar ao Judiciário suas pretensões (ação), como dispõe este $\S 2^{\circ}$, é subtrair-lhes ou reduzir-lhes a possibilidade de acesso à Justiça" (In: Comentários à nova lei de falência... Op. cit., p. 283).

${ }^{612}$ In: Comentários... Op. cit., p. 145.

${ }^{613}$ Esse, aliás, foi um dos obstáculos à efetividade da AGC em legislações anteriores.
} 
privilegiar a segurança jurídica da deliberação, para não comprometer a efetividade dos institutos disciplinados na lei concursal.

Apesar da relevância da argumentação, entendemos que a regra do art. 39, § $2^{\circ}$, da LRF, se não pode ser chamada de inconstitucional, deve ser aplicada cum grano salis, sempre a partir da análise do caso concreto, sob pena de resultar justamente naquilo que a lei quis evitar: insegurança jurídica. Parece adequada, assim, a interpretação dada por autores como MANOEl Justino BEZERra Filho ${ }^{614}$, MARIO SÉRgio MiLANi ${ }^{615}$ e ERASMO VALLADÃo FrANÇA ${ }^{616}$ no sentido de que tal dispositivo não poderá dar guarida a hipóteses de fraudes ou de evidente prejuízo para os participantes do processo.

Tal raciocínio se acha amparado na própria previsão do parágrafo $3^{\circ}$ do mesmo artigo, que estabelece que a posterior invalidação de deliberação da assembléia não atingirá os direitos de terceiros de boa-fé, respondendo os credores que a aprovarem pelos prejuízos comprovados causados por dolo ou culpa. Ou seja, a invalidação da deliberação não acarretará na anulação automática dos atos praticados com base nela ${ }^{617}$, preservando-se em todo caso os terceiros de boa-fé.

\subsection{Eficácia das deliberações}

As deliberações da Assembleia-Geral de Credores, desde que válidas, vinculam todos os credores, ainda que dissidentes ou ausentes, ressalvando-se que a eficácia das

\footnotetext{
614 "Evidentemente, à luz dos princípios gerais de direito, principalmente ante o princípio da boa-fé, a este artigo será dada a correta aplicação pela jurisprudência, pois nem a própria lei positiva tem poderes para convalidar o ato fraudulento e prejudicial à comunidade dos credores" (Nova lei de recuperação... Op. cit., p. $121)$.

615 “na nossa opinião o comando veiculado no $\S 2^{\circ}$ do art. 39 ... poderá ser plenamente aplicado, desde que o voto proferido pelo credor em questão - cujo crédito foi posteriormente declarado inexistente, reduzido ou reclassificado desfavoravelmente - não tenha, cumulativamente, sido determinante no quórum de deliberações tomadas na assembléia-geral, tampouco gerado prejuízo aos demais credores" (Lei de recuperação judicial... Op. cit., p. 187).

616 “O que se deve entender é que as deliberações da Assembléia-Geral não serão invalidadas pelo só fato de ocorrer uma decisão judicial posterior acerca da existência, quantificação ou classificação de créditos. O que não quer dizer que, verificada posteriormente, por decisão judicial, a existência, por exemplo, de um crédito forjado, que tenha sido determinante para a deliberação de aprovação de uma recuperação judicial absolutamente inviável, com a nomeação de um gestor judicial conluiado com o devedor etc., não possam os interessados requerer a anulação da deliberação" (In: Comentários... Op. cit., p. 210).
}

${ }^{617}$ Cf. ERASMo VAlladẽo França. In: Comentários... Op. cit., p. 196. 
resoluções que atinjam direitos especiais de credores ${ }^{618}$ ou direitos de terceiros dependerá da concordância destes ${ }^{619}$, ainda que posterior ao conclave.

Além disso, é importante ressaltar que as deliberações da AGC só adquirem eficácia plena depois de homologadas pelo juiz. Com efeito, opera-se no regime concursal algo distinto do que ordinariamente ocorre com os acordos celebrados durante um processo judicial, que vinculam as partes independentemente da homologação.

Em regra, a sentença de homologação produz efeitos apenas processuais, com o fito de extinguir o processo (CPC, art. 269, III), ou, em determinados casos, constituir título executivo judicial (CPC, art. 475-N, III). Porém, independentemente da "aprovação" do juiz, o acordo entre as partes, desde que válido, é eficaz por si só, vinculando os convenentes desde a celebração:

“Como negócios jurídicos que são, o reconhecimento do pedido, a transação e a renúncia ao direito produzem por si mesmos os efeitos de direito substancial programados pelas partes, independentemente de qualquer participação judicial. Tal é a eficácia vinculante dos contratos (CC, art. 1.080 ss.), reiterada no tocante à transação mediante a fórmula consistente em atribuir-lhe efeito de coisa julgada (art. 1.030). Para que operem o efeito processual de extinguir o processo, contudo, bem como para serem títulos executivos judiciais se for o casos, a lei exige que sejam homologados por sentença judicial (art. 584, inc. III)" (CÂNDIDO RANGEL DINAMARCO ${ }^{620}$ ).

Já no processo concursal, infere-se que as deliberações da Assembleia, mesmo aquelas que se assemelham a uma transação, só produzirão efeitos para além dos limites do processo depois de homologadas pelo juiz ${ }^{621}$, de modo que só obrigarão as partes se e quando receberem a chancela judicial.

\footnotetext{
${ }^{618}$ P. ex., para excluir a sua garantia.

${ }^{619}$ Idem, p. 190.

${ }^{620}$ Instituições de direito processual civil. São Paulo: Malheiros, 2001. v. 3, p. 267.

621 O art. 102, § 5º da Lei $\mathrm{n}^{\circ} 2.024$, de 1908, dispunha expressamente que cabia ao juiz "vetar" as deliberações inválidas da AGC.
} 
Em virtude da autoridade que decorre do Estado, compete ao juiz realizar juízo de licitude ${ }^{622}$ sobre o que foi resolvido na assembleia, a fim de verificar se as deliberações nela tomadas padecem de vício formal ou violam lei imperativa. Só então, depois da homologação, as deliberações produzirão os efeitos esperados pelos credores, vinculandoos ao que tiver sido decidido.

Assim, por exemplo, ainda que os credores tenham aprovado o plano apresentado pelo devedor, a concessão da recuperação judicial depende do ato homologatório do juiz, antes do qual não produzirão efeitos quaisquer convenções quanto à forma de pagamento dos credores, dilações de prazo, moratórias etc.

A propósito do tema, são valiosas as lições de Trajano DE MiRAndA VALVERDE $^{623}$, que embora se refiram à concordata (do Decreto 5.746/1929) aplicam-se perfeitamente à lei vigente:

"Na concordata, porém, ainda que a proposta tenha sido unanimemente aceita pelos credores habilitados, nenhum vínculo substancial ainda se estabeleceu entre as partes, pois que lhe falta um ato de vontade, a decisão do juiz, este que, depois de examinar se a proposta e a aceitação obedecerem às formalidade prescritas na lei, se a vontade das partes não colide com a finalidade econômico-jurídica do instituto, concorrerá, em virtude da autoridade que lhe vem do Estado, para a constituição de um ato jurídico complexo - a concordata -, a que a lei atribui determinados efeitos,

Quando a lei declara que a proposta de concordata, de pagamento à vista ou a prazo, "para ser válida e produzir efeitos jurídicos", deve ser formulada nos termos prescritos na lei, não se refere senão à validade e aos efeitos processuais decorrentes da conformidade da proposta e da aceitação com os preceitos legais, que autoriza, pois isso, o prosseguimento do processo da concordata até a sentença do juiz. Com efeito, se a proposta não oferece os requisitos legais, o juiz indefere, desde logo, o pedido do devedor para a convocação de seus credores; e se a proposta não for aceita, o juiz dissolve a assembléia, considerando-a rejeitada; se for aceita com violação dos preceitos legais, a concordata não se forma, pois negará o juiz apoio ao acordo.

$\mathrm{O}$ acordo, conseguintemente, do devedor com os seus credores, ainda quando resultante da vontade unânime de todos estes, não produz, só por si, os efeitos jurídicos visados pelas partes; é ainda necessário um ato de vontade do juiz, manifestado na sentença que julga válida a

${ }^{622}$ E não juízo de conveniência.

${ }^{623}$ A Falência no Direito Brasileiro. Rio de Janeiro: Ariel, 1934. v. 3, p. $27-29$. 
proposta e a aceitação. Os efeitos jurídicos não aparecem senão depois que houve a convergência dessas vontades, que concorrem para a formação da concordata".

O mesmo vale para quaisquer outras deliberações da AGC: podem os credores aprovar a constituição do Comitê e eleger os seus representantes, mas quem os nomeará será o juiz; da mesma forma, compete ao magistrado a nomeação da pessoa escolhida pelos credores para desempenhar as funções de gestor judicial; no caso de pedido de desistência do devedor, ainda que haja a concordância da assembleia, a extinção do processo é ato eminentemente judicial; e, finalmente, ainda que aprovada forma alternativa de alienação do ativo, nenhum bem será vendido antes que o juiz assim autorize.

\section{Ata dos trabalhos}

Ao final dos trabalhos da AGC deverá ser lavrada uma ata ${ }^{624}$, que conterá o registro dos presentes e o relato de todos os acontecimentos relevantes, como o resultado de cada uma das deliberações, com a anotação dos votos de cada credor, e os eventuais protestos feitos credores, que poderão ser formulados tanto oralmente quanto por escrito, já que a lei não prescreve forma específica ${ }^{625}$.

Por analogia ao art. $130, \S 1^{\circ}$, da Lei das S.A., deve-se admitir, sobretudo por razões práticas ${ }^{626}$, a fim de facilitar e agilizar os trabalhos, que a ata seja lavrada na forma de sumário ${ }^{627}$ dos fatos ocorridos, contendo a transcrição apenas das deliberações tomadas,

\footnotetext{
${ }^{624}$ A ata pode ser concebida "como o resumo das formalidades e das deliberações que houve na assembléia geral, constituindo documento comprobatório dos atos jurídicos levados a efeito durante os trabalhos. Em um sentido mais amplo, a ata é o documento que concentra e perpetua os fatos ocorridos durante a assembléia" (Modesto Carvalhosa. Comentários à Lei de Sociedades Anônimas... Op. cit., v. 2, p. 753).

${ }^{625}$ Valendo lembrar que a ata não é requisito de validade das deliberações, mas fator de sua eficácia (cf. JoÃO Bosco Cascardo de GouvÊA. Recuperação e Falência... Op. cit., p. 92).

626 “O $\S 1^{\circ}$ do artigo 130, como há pouco dito, introduziu no ordenamento jurídico a ata sintética, onde os fatos ocorridos, 'inclusive dissidências e protestos, serão registrados na mais apertada síntese possível praticamente uma singela menção - transcrevendo-se apenas as deliberações tomadas na reunião. Sem sombra de dúvida, na prática quase todas as reuniões assembleares aprovam a redação da ata na forma de sumário, diante da praticidade de sua lavratura e da discrição de sua narrativa" (RICARDO TEPEDINO. In: LAMY FILHO, Alfredo; e BULHÕES PEDREIRA, José Luiz (Coords.). Direito das Companhias. Rio de Janeiro: Forense, 2009, v. 1, p. 968).

627 “Ainda que sumária, a ata deverá sempre registrar o dia e o local da reunião; o horário em que a assembléia foi instalada; a composição da mesa e sua eleição, quando o caso; a regularidade de sua convocação; a verificação, vis-à-vis do Livro de Presença, do quórum de instalação, se em primeira convocação; o teor das deliberações aprovadas e a menção àquelas rejeitadas pelo voto; o horário em que
} 
o registro das dissidências e protestos, desde que: $(i)$ os documentos ou propostas submetidos à assembleia, assim como as declarações de voto ou dissidência, referidos na ata, sejam numerados seguidamente, autenticados pela mesa ${ }^{628}$ e por qualquer credor que o solicitar; (ii) a mesa, a pedido de credor interessado, autentique exemplar ou cópia de proposta, declaração de voto ou dissidência, ou protesto apresentado.

Em sentido contrário, Modesto CARvalHosA ${ }^{629}$ afirma que a lavratura da ata em forma de sumário é incompatível com a Assembleia-Geral de Credores:

\begin{abstract}
"Quanto ao regime de declarações em ata, verifica-se que a legislação falimentar, diferentemente da Lei de Sociedades Anônimas (Lei $n^{\circ}$ 6.404/76), não admite a forma sintética da ata da assembleia geral de credores. Assim, temos que a ata deverá ser lavrada contendo o inteiro teor dos protestos e manifestações dos credores, inclusive aquelas apresentadas por escrito à mesa diretora dos trabalhos. Com efeito, a ata é o documento comprobatório dos negócios jurídicos levados a efeito durante os trabalhos da assembleia e, por essa razão, deve conter o inteiro teor das discussões havidas e das deliberações tomadas. Em um sentido mais amplo, a ata é o documento extrajudicial que concentra e perpetua os fatos ocorridos durante a assembleia. Esse rigor da ata é plenamente justificável, pois se trata de documento probatório destinado a produzir efeitos em juízo".
\end{abstract}

Com a devida vênia, suas razões não convencem.

Sabe-se que a Lei $\mathrm{n}^{\circ}$ 11.101/2005 "não determina muito claramente de que forma se lavrará a ata",630, exigindo apenas que seja escrita. Logo, se não há forma prescrita em lei nem vedação expressa a que a ata seja lavrada em forma de sumário, devese reconhecer a validade desta, conforme decorre do art. 104, III, do Código Civil ${ }^{631}$.

\footnotetext{
suspendeu a reunião para a lavratura da ata e o horários em que foi reaberta e, depois, encerrada." (Idem, p. 967). A lição de RICARDO TEPEDINO refere-se às assembleias das sociedades anônimas, mas se aproveita integralmente à assembleia-geral de credores.

628 “a mesa será integrada por duas pessoas, o presidente e o secretário. Em regra, o administrador judicial exercerá a presidência." (FÁBIO UlHOA COELHO. Comentários... Op. cit., p. 132).

${ }^{629}$ In: Comentários... Op. cit., p. 275-276.

${ }^{630}$ ERASMo VAlladẽo França. In: Comentários... Op. cit., p. 207.

${ }^{631}$ Art. 104. A validade do negócio jurídico requer: (...) III - forma prescrita ou não defesa em lei.
} 
Ademais, a imposição da forma analítica não se justifica, como quer o Prof. Carvalhosa, por se tratar de "documento probatório destinado a produzir efeitos em juízo". Ora, no regime das sociedades anônimas, a ata lavrada na forma de sumário, desde que observadas as cautelas legais, faz exatamente a mesma prova da ata analítica e produz os mesmos efeitos, inclusive em juízo. Não há por que ser diferente em se tratando de AGC, máxime se considerarmos que a lavratura da ata, aqui, diferentemente do que ocorre com as companhias, é supervisionada por alguém de confiança do juízo (o administrador judicial).

Assim, como não se vislumbra qualquer prejuízo, devem prevalecer as razões de ordem prática que justificam a lavratura da ata na forma de sumário, já admitida por vários doutrinadores, como ERASMO VALlADÃo FrANÇA ${ }^{632}$ e MARIO SERGIO MILANI ${ }^{633}$.

Ressalte-se, por fim, que a ata será assinada ${ }^{634}$ pelo presidente, pelo devedor e por dois membros de cada uma das classes votantes, devendo então ser entregue ao juiz, juntamente com a lista de presença, no prazo de 48 (quarenta e oito) horas contadas do encerramento da assembleia (LRF, art. $37, \S 7^{\circ}$ ).

\footnotetext{
632 "A lei 11.101 não determina muito claramente de que forma se lavrará a ata, em especial se o poderá ser sob a forma de sumário dos fatos ocorridos, com o registro das eventuais dissidências e protestos dos credores, e com a autenticação, pela mesa (no caso, administrador judicial e secretário), de cópias das declarações de voto e protestos apresentados pelos credores, como permite, por exemplo, a Lei das S/A (art. 130 , caput $\mathrm{e} \S 1^{\circ}$, da Lei 6.404/1976). A nosso ver, contudo, nada impede a lavratura da ata sob forma de sumário, que se destina a facilitar e agilizar os trabalhos do conclave e não traz prejuízos a ninguém" (In: Comentários... Op. cit., p. 207).

633 "A lei sob comento é omissa no tocante à forma da lavratura da ata. Por isso, não vislumbramos qualquer óbice quanto à adoção da forma sumária.” (Lei de Recuperação Judicial... Op. cit., p. 181-182).

${ }^{634}$ Para MARio SERGio MilANI, a ata também deveria ser assinada pelo secretário: "Acreditamos ter havido um cochilo do legislador quanto à omissão relativa à assinatura do secretário na ata da assembléia, uma vez que cabe a ele redigi-la, registrando as deliberações e os eventuais incidentes relevantes" (Idem, p. 182). No mesmo sentido é opinião de RONALDO ALVES DE ANDRADE: "Note-se que o dispositivo não demanda a assinatura do secretário, mas cremos que deva ela constar, na medida em que é natural constar de toda ata o nome de quem a elaborou" (In: Comentários... Op. cit., p. 188).
} 
CAPÍTULO IV - NOTAS SOBRE O ABUSO DO DIREITO DE VOTO 


\section{CAPÍTULO IV - NOTAS SOBRE O ABUSO DO DIREITO DE VOTO}

\section{Controle judicial das deliberações e abuso do direito de voto.}

Como já disse aqui tantas vezes, a Lei nº 11.101/2005 conferiu aos credores a prerrogativa de decidir a solução para a crise do devedor comum. A concessão da recuperação judicial se subordina à vontade deles, diferentemente do que ocorria com a concordata no regime do Decreto-Lei $\mathrm{n}^{\mathrm{o}} 7.661 / 45$, cujo deferimento dependia apenas do preenchimento de certos requisitos objetivos e subjetivos verificados pelo juiz.

Um rompimento assim tão drástico com um sistema que teve vigência por cerca de 50 anos era mesmo de causar certa perplexidade - para não dizer inconformismo -, sobretudo porque a lei retira do juiz o poder de impor a solução que entende adequada sobre aquela legitimamente determinada pelos credores.

Por isso, não foram poucos que invocaram os princípios informadores da lei para sustentar que o juiz não está adstrito às deliberações da Assembleia-Geral de Credores, porque não pode ser privado do exercício das suas funções jurisdicionais ${ }^{635}$. Entre esses, destaca-se MANOEL Justino BEZERRA FILHO ${ }^{636}$ :

\footnotetext{
${ }^{635}$ Nesse sentido, assim leciona JORGE LOBO: "O juiz, no processo civil comum, exerce: a) poder 'de caráter jurisdicional', 'relacionado com a atividade decisória', denominado 'poder-fim'; b) 'poder-meio', 'de feição instrumental', como o poder de direção do processo, o poder instrutório e o poder de coerção; c) poder administrativo. (...) É curial que, ao exercer os poderes de caráter jurisdicional, instrumental ou administrativo, o juiz não é um órgão passivo, mero homologador das decisões da assembléia geral ou do comitê de credores ou do administrador judicial, pois, ao ordenar o processamento da ação, proferir despachos, decisões e sentenças, superintender a administração da empresa em crise, enfim, presidir o processo de recuperação, deve fazê-lo com tirocínio, competência e plena liberdade, formando sua convicção, seu "livre convencimento", de acordo com as provas dos autos (...). O juízo da ação de recuperação judicial deve exercer, sempre, necessária e obrigatoriamente (...) o controle de legalidade material ou substancial, em que verificará se houve, por exemplo: a) fraude à lei ou abuso de direito, quer por parte do devedor, quer dos credores; b) acordos contrários à lei, à moral, aos bons costumes, à boa-fé objetiva, ao interesse público etc. Incumbe-lhe, ademais, dependendo do caso concreto, exercer controle de mérito, tanto do plano de recuperação quanto da decisão da assembléia geral de credores, como, por exemplo, quando: a) a deliberação for por maioria e os dissidentes hajam deduzido objeções e votos divergentes; b) a deliberação for contrária à aprovação do plano e o devedor haja apresentado defesa e postulado a anulação do conclave por fraude à lei, abuso de direito, preterição de formalidade essencial etc." (In: Comentários... Op. cit., p. 218-220).

${ }^{636}$ Nova lei de recuperação e falências... Op. cit., p. 113.
} 
"Em que pese determine a Lei a participação dos credores na maioria dos casos, o juiz, pelo poder que lhe é conferido, pode deixar de acatar decisões da assembléia-geral se atentarem contra as disposições e princípios da Lei ou se tiver qualquer outro motivo para entender de forma diversa, sempre evidentemente fundamentando sua disposição".

Com base nesse raciocínio, alguns autores chegaram a defender que o magistrado poderia conceder a recuperação judicial com base no plano rejeitado pela assembleia $^{637}$, ou mesmo negá-la a despeito da aprovação dos credores ${ }^{638}$, tudo a partir do juízo que fizesse acerca da viabilidade econômica do devedor, a fim de atender ao princípio da função social da empresa.

Contudo, a ideia de que o juiz teria discricionariedade sobre a concessão da recuperação ou decretação da falência - que já era refutada por parte da doutrina ${ }^{639}$ - vem

${ }^{637}$ Cf. LUIS INÁCIO VIGIL NETO: "Não obstante, o magistrado tem o poder de impor o plano, evitando o decreto falencial, se reconhecer o desempenho de função social pela empresa em crise. Dentro das diversas propostas debatidas no Congresso brasileiro, prevaleceu a que mitiga o poder do juiz de contrariar a vontade manifestada pelos credores da assembléia não constitui um ato de vontade absoluta do juiz, mas vinculado a alguns critérios objetivos. Somente com a presença de todos esses requisitos poderá juiz examinar, de forma subjetiva, se a empresa é estrategicamente importante no seu contexto social. (...) Na idéia de função social, adotou-se o princípio de relevância do ente econômico em seu contexto social. Dessa forma, a função social não se mede por atividades sociais ou filantrópicas, mas pela importância da empresa no contexto de sua operação econômica, nacional, estadual, regional ou local, na geração de emprego e riqueza" (Teoria falimentar e regimes recuperatórios. Porto Alegre: Livraria do Advogado, 2008, p. 172-173).

${ }^{638}$ FÁBIO UlHOA COELHO sustentou que o juiz poderia decretar a falência mesmo tendo os credores aprovado o plano, caso convencido de que a solução ajustada seria incapaz de promover a superação da crise econômico-financeira do devedor: "Pela lei brasileira, os juízes, em tese, não poderiam deixar de homologar os planos aprovados pela Assembleia dos Credores, quando alcançado o quórum qualificado da lei. Mas, como a aprovação de planos inconsistentes levará à desmoralização do instituto, entendo que, sendo o instrumento aprovado um blá-blá-blá inconteste, o juiz pode deixar de homologá-lo e incumbir o administrador judicial, por exemplo, de procurar construir com o devedor e os credores mais interessados um plano alternativo" (In: Comentários... Op. cit., p. 224). No mesmo sentido, confira-se a posição de NEWTON DE LUCCA: "Imagine-se um plano visivelmente inconsistente que venha a ser aprovado pela assembleia de credores (não por convicção íntima destes no êxito do plano, de resto um grotesco mistifório, mas sim à míngua de alguma alternativa para eles que não a declaração da falência do devedor...): Estaria o juiz obrigado a aceitá-lo? Também aqui, a meu ver, a resposta deverá ser igualmente negativa. Não vejo como possa entender-se que o magistrado, convencido da inconsistência do plano, esteja obrigado a fazer o papel de inocente útil, referendando uma solução que, de antemão, sabe ser absolutamente inadequada..." (Comentários à nova lei de recuperação de empresas e falências. São Paulo: Quartier Latin, 2005, p. 33).

${ }^{639}$ Cf. EDUARDo SECCHI MuNHOZ, "Não cabe, portanto, ao juiz nenhuma margem de discricionariedade a respeito da matéria, ou, em outras palavras mais precisas, não há na lei, quanto a esse aspecto, conceitos abertos (chamados conceitos indeterminados) que confiram ao juiz margem ampla de interpretação para a emissão dos respectivos juízos de legalidade. Assim, uma vez preenchidos os requisitos da lei, que nesse aspecto não adota nenhuma cláusula aberta ou conceito indeterminado, e aprovado o planos credores, cumpre ao juiz conceder a recuperação; se, por outro lado, não se configurar tal hipótese, cabe ao juiz decretar a falência" (In: Comentários, p. 284). No mesmo sentido se posiciona MAURo Rodrigues PENTEAdo: "Por aí se vê que o juiz está proibido de 'conceder' a recuperação judicial se o plano respectivo não contar com a aprovação dos credores, tácita (art. 55), plena (art. 45) ou segundo os critérios deliberativos diferenciados previstos no art. $58, \S 2^{\circ}$. Não é o magistrado que emite juízo valorativo sobre a função da atividade empresarial em crise, na extensão e alcance com que vêm definidos no art. 47. Essa decisão é exclusiva dos 
sendo aos poucos abandonada, notadamente porque a jurisprudência tem se firmado no sentido de privilegiar a vontade dos credores, tal como previsto na lei:

\begin{abstract}
"Recuperação Judicial. Convolação em falência, em virtude de objeção dos credores trabalhistas, em assembleia geral, ao plano de recuperação. Impossibilidade de o juiz manter a recuperação judicial, desprezando a objeção dos credores, fora das hipóteses do art. 58, § $1^{\circ}$, da L. 11.101/05. Assembleia com autonomia para aprovar ou se opor ao plano apresentado pelo devedor. Recurso não provido". ${ }^{640}$
\end{abstract}

Isso não significa, obviamente, que o juiz tenha se tornado um mero chancelador da vontade credores $^{641}$, uma vez que não se lhe retirou (nem poderia) o juízo de licitude das deliberações da Assembleia-Geral de Credores e dos votos nela proferidos $^{642}$. Ocorre, no entanto, que esse juízo de licitude não compreende um juízo de conveniência das resoluções tomadas pelos credores, de modo que o magistrado não poderá contrariá-las com base em razões discricionárias, isto é, a partir da própria convicção acerca da melhor solução para a crise da empresa.

Que fazer então diante de deliberações que, sem incorrer em nenhuma irregularidade formal nem desrespeitar vedação legal específica, forem injustificadamente prejudiciais ao devedor, aos próprios credores ou à sociedade, contrariando os princípios da Lei e da Constituição? Estaria o juiz, por que impedido de agir de forma discricionária, obrigado a avalizar essas deliberações?

Logicamente, o juiz não deve obediência cega à vontade dos credores, o que nada tem a ver com o fato de ser privado de discricionariedade: o juiz não pode, repita-se, interferir na autonomia das partes para impor a solução negocial que lhe parece mais adequada, mas deve repudiar o exercício do direito que contrarie os fins sociais e

credores, empresários ao teor do art. 966 do Código Civil de 2002, que também vem cuidar para que a atividade que exerçam cumpra devidamente essa função" (In: Comentários... Op. cit., p. 127-128).

${ }^{640}$ TJSP, $1^{\text {a }}$ Câm. de Dir. Empresarial., AI nº 0183061-44.2012.8.26.0000, rel. Des. Francisco Loureiro, j. 11.12.2012. No mesmo sentido: "Observadas todas as formalidades legais e aprovado o plano pelo quorum previsto no artigo 45, o juiz, ao afastar a exigência do artigo 57, deve conceder a recuperação judicial. Não compete ao magistrado apreciar a viabilidade econômico-financeira do plano, que deve ser instruído com pareceres técnicos de profissional habilitado, sujeitos ao crivo exclusivo do conclave assemblear." (TJSP, Câm. Fal. e Recup., AI nº 9073125-67.2008.8.26.0000, rel. Des. Pereira Calças, j. 30.7.2008).

${ }^{641}$ Até porque não poderia excluir do Judiciário a apreciação de lesão ou ameaça a direito (Constituição Federal, art. $5^{\circ}, \mathrm{XXXV)}$.

${ }^{642}$ Vide itens 9.3 e 9.4 do Capítulo III. 
econômicos a que se destina, a boa-fé ou os bons costumes. Deve repudiar, enfim, o abuso do direito.

O juiz decretará a invalidade das deliberações assembleares quando verificar que ela foi formada a partir de votos abusivos, reputados ilícitos pelo art. 187 do Código Civil $^{643}$. O reconhecimento da abusividade, por sua vez, tem relação direta com o descumprimento dos princípios informadores da lei ${ }^{644}$ e da Constituição, que irradiam valores a serem realizados no caso concreto ${ }^{645}$.

Como o fim social e econômico do direito de voto está inegavelmente relacionado à preservação da função social da empresa (princípio maior da lei a que os credores também se sujeitam) ${ }^{646}$, a teoria do abuso de direito constitui fundamento para que o juiz, à luz do caso concreto, possa controlar a licitude da deliberação que rejeita ou aprova o plano de recuperação, sem que disso resulte violação da sistemática eleita pela lei concursal vigente.

Daí que, apesar de a Assembleia-Geral de Credores ser soberana, o mérito das suas deliberações não escapa do crivo judicial, e não apenas nas hipóteses de fraude à lei

${ }^{643}$ Art. 187. Também comete ato ilícito o titular de um direito que, ao exercê-lo, excede manifestamente os limites impostos pelo seu fim econômico ou social, pela boa-fé ou pelos bons costumes.

644 “O voto do credor na assembleia geral também se sujeita, de certa forma, aos princípios comentados. Nesse ponto, é bom notar que o credor vota considerando o seu interesse em receber o crédito. Esse o interesse que legitima seu voto. Não se pode impor a ele a obrigação de aprovar o plano. Mas pode ocorrer eventual abuso no exercício do voto ou conflito de interesses, e esses serão confrontados com as diretrizes da lei." (ARNOLDO WALD e IVO WAISBERG. In: CORRÊA-LIMA, Osmar Brina; e LIMA, Sérgio Mourão Correa (coord.). Comentários à nova Lei de Falência e Recuperação de Empresa. Rio de Janeiro: Forense, 2009, p. 321).

645 Para o constitucionalismo moderno, mais do que conferir validade às normas jurídicas inferiores, a Constituição irradia sobre elas os seus valores, os quais informarão a aplicação e interpretação dessas normas (e, por conseguinte, a própria atuação do magistrado). Nesse sentido, comentando sobre a chamada constitucionalização do direito, ensina Luís RoBERTO BARROSO: "Sedimentado o caráter normativo das normas constitucionais, o Direito contemporâneo é caracterizado pela passagem da Constituição para o centro do sistema jurídico, onde desfruta não apenas da supremacia formal que sempre teve, mas também de uma supremacia material, axiológica. Compreendida como uma ordem objetiva de valores e como um sistema aberto de princípios e regras, a Constituição se transforma no filtro através do qual se deve ler todo o direito infraconstitucional. Esse fenômeno tem sido designado como constitucionalização do Direito, uma verdadeira mudança de paradigma que deu novo sentido e alcance a ramos tradicionais e autônomos do Direito, como o civil, o administrativo, o penal e o processual." (Curso de Direito Constitucional Contemporâneo. 2 ed. São Paulo: Saraiva, 2002, p. 86-87).

${ }^{646}$ O que não significa, obviamente, que os credores tenham o dever de preservar a empresa a qualquer custo, até porque, tratando-se de empresa inviável, a liquidação tende a ser a melhor solução, inclusive do ponto de vista social. 
imperativa, mas igualmente quando o exercício dessa soberania estiver em desacordo com os princípios legais e éticos que a fundamentam ${ }^{647}$.

Aparentemente, aí se acha importante solução, já constante do ordenamento, para resolver o confronto entre os interesses dos credores e o princípio da preservação da empresa, bem como, de certo modo, para contornar a falha legislativa na disciplina do “cram down", referida em comentários anteriores.

\section{Considerações gerais sobre o abuso de direito}

A expressão "abuso de direito" deriva do verbo abusar (no latim, abutor), primitivamente utilizado no sentido de "usar com bastante intensidade", mas posteriormente empregado para significar "uso indevido, excessivo" 648 . Abuso do direito seria, pois, o uso indevido ou excessivo de um direito subjetivo.

Existe certa divergência doutrinária quanto à origem dessa figura: enquanto alguns atribuem ao direito romano o ineditismo da sua disciplina, outros tantos afirmam que os primeiros a cogitarem do abuso de direito teriam sido os franceses, no século XIX, a partir das famosas decisões judiciais proferidas em conflitos de vizinhança.

Como bem aponta EDUARDO JORDÃO ${ }^{649}$, a causa dessa divergência reside na confusão feita entre os conceitos de noção - que é "a idéia de existência, percepção empírica de uma realidade, um conhecer primitivo" do instituto - e de teoria - "o produto de um trabalho científico, da sistematização e problematização de um saber", que nasce e se desenvolve depois de constatada a existência (noção) do instituto.

\footnotetext{
647 “A disciplina jurídica da falência deve buscar soluções procedimentais que permitam a interferência jurisdicional sempre que a atuação dos credores se desvie dos objetivos previamente determinados. Há de se buscar regras procedimentais que, concretizando o princípio (a cláusula aberta) insculpido no art. 47 da Lei $\mathrm{n}^{\mathrm{o}} 11.101 / 2005$, organizem os interesses afetados pela crise da empresa, alçando o juiz ao papel de presidente do processo de negociação e de árbitro dos eventuais desvios de rota que possam comprometer o atendimento dos objetivos definidos pelo legislador" (EDUARDO SECCHI MuNHOZ. "Anotações sobre os limites do poder jurisdicional na apreciação do plano de recuperação judicial”. Revista de Direito Bancário e do Mercado de Capitais, n. 36, p. 191-192).

${ }^{648}$ Cf. Álvaro Villaça Azevedo. Código Civil Comentado. São Paulo: Atlas, 2003, v. 2, p. 363.

${ }^{649}$ Repensando a Teoria do Abuso de Direito. Salvador: JusPodivum, 2006, p. 56.
} 
Relativamente ao abuso de direito, a origem da noção desse instituto difere do início do seu estudo sistemático e científico (a sua teoria), convindo proceder a essa distinção.

\subsection{Origem da noção do abuso do direito}

A ideia de abuso do direito é milenar, encontrando evidências no Código de Hammurabi, escrito por volta 1780 a.C., bem como no pensamento aristotélico ${ }^{650}$. No entanto, para a maior parte da doutrina ${ }^{651}$ a noção do abuso do direito só começou a ganhar corpo no direito romano clássico.

Foi evidenciada especialmente pelo adágio summum ius, summa iniuria (CíCERO, De Officiis, I, 10,3), que se traduz por "supremo direito, suprema injustiça", exprimindo a ideia de que o "direito elevado ao máximo" resulta em "injustiça em grau máximo", esclarece CARLOS MAXIMILIANO ${ }^{652}$.

Nesse mesmo sentido, LimOngI FRANÇA ${ }^{653}$ destaca o brocardo jurídico de JUSTINIANO segundo o qual "não devemos fazer uso do nosso direito de maneira inadequada" (male enim nostro iure uti non debemus) ${ }^{654}$, bem como a condenação, pelo jurisconsulto Gaio, do martírio dos escravos e dos excessos dos pródigos, a justificar a interdição destes últimos.

Ainda sobre a origem da noção do abuso de direito, vale mencionar a figura da aemulatio $^{655}$, criação pretoriana do período pós-clássico, consistente na vedação dos atos de emulação, praticados pelo titular do direito com o intuito exclusivo de prejudicar terceiros.

\footnotetext{
${ }^{650}$ Cf. Cláudio ANTONio SoAREs LevadA. O abuso e o novo direito civil brasileiro. Jundiaí: UniAnchieta, 2007, p. 15-17.

${ }^{651}$ Em sentido contrário, ORLANDO GOMES afirma que "o abuso de direito é construção do pensamento jurídico de nossos dias” (Introdução ao Direito Civil. 17 ed. Rio de Janeiro: Forense, 2000, p. 131).

${ }^{652}$ Hermenêutica e aplicação do direito. Rio de Janeiro: Forense, 1990, p. 169.

653 “Responsabilidade Civil e Abuso de Direito". In: Revista do Advogado, n. 19. p. 42.

654 Surgido, segundo EDUARDO JORDÃo (Repensando a Teoria... Op. cit., p. 58), em contraposição ao brocardo neminem laedit qui suo jure utitu" ("quem exerce o seu direito a ninguém prejudica").

655 cf. RenAto RiBeiro. “Abuso de Direito”. In: Miguel ReAle (coord). Experiência do direito. CampinasSP: Millennium, 2004. p. 198.
} 
Conforme PONTES DE MIRANDA ${ }^{656}$, essa proibição dos atos de emulação - que revela "concepção intencionalista do abuso do direito" - consta de várias passagens do Digesto:

\begin{abstract}
"Diz-se na L.1, § 12, D., de aqua et aquae pluviae, 39, 3 (UlPIANO): 'Denique Marcilus scribit cum eo, qui in suo fodiens vicini fontem avertit, nihil posse agi, nec de dolo actionem: et sane non debet habere, si non animo vicino nocendi, sed suum agrum meliorem faciendi id fecit'. O proprietário pode abrir sulcos no seu prédio, prejudicando as fontes do vizinho, mas, se o faz para melhorar o seu e não com o ânimo de prejudicar o outro. ...

Lê-se na L.2, § $9^{\circ}$ (PAULO): 'Idem Labeo ait, si vicinus flumen torrentem averterit, ne aqua ad eum perveniat, et hoc modo sit effectum, ut vicino noceatur, agi cum eo aquae pluviae arcendae non posse: aquam enim arcere hoc esse curare, ne influat. quae sententia verior est, si modo non hoc animo fecit, ut tibi noecat, sed ne sufi noceat'. Também nesse caso, havendo inundação, se as obras do proprietário do prédio invadido ofenderem ao do vizinho, não terá êsse a ação aquae pluviae arcendae; salvo se feitas, não para impedir danos ao seu prédio, e sim para lesar o outro. Pura concepção intencionalista do abuso do direito".
\end{abstract}

Como se vê, os romanos também identificavam a possibilidade do uso indevido, exagerado de um direito, ainda que não tenham se ocupado de teorizá-lo e discipliná-lo de forma específica.

\title{
2.2. Origem da teoria do abuso do direito
}

Ainda que a noção de abuso do direito seja muito mais antiga, esse instituto só passou a ser sistematizado na era contemporânea ${ }^{657}$.

Costuma-se creditar o ineditismo dessa sistematização, como já se adiantou, às decisões proferidas pelos tribunais franceses em conflitos de vizinhança ocorridos entre a metade do século XIX e início do XX.

\footnotetext{
${ }^{656}$ Tratado de Direito Privado: Direito das Obrigações. 3 ed. Rio de Janeiro: Borsoi, 1972, t. 53, p. 64.

${ }^{657}$ Cujo início, segundo a maior parte dos historiadores, deu-se em 1789, com a Revolução Francesa.
} 
Os casos mais famosos são o da chaminé falsa (construída pelo proprietário do terreno, sem nenhuma utilidade para si, com a intenção de obstar a insolação da construção ao lado) e o de Clément-Bayard (em que o dono do terreno fez nele levantar hastes de dezessete metros de altura com o só propósito de perfurar os dirigíveis construídos no imóvel do vizinho, para forçar este a lhe comprar a propriedade).

A Justiça francesa reconheceu a ilicitude daqueles atos de emulação, chegando até a empregar, no caso "Clément-Bayard", a expressão abus du droit de propriété (no vernáculo: "abuso do direito de propriedade").

As decisões francesas ganharam notoriedade sobretudo porque o art. 544 do Código Civil daquele país rezava que "a propriedade é o direito de gozar e dispor das coisas da maneira mais absoluta..." ${ }^{658}$, sendo o liberalismo e o individualismo a tônica da legislação naquela época.

A despeito da sua relevância, contudo, não parece correto atribuir à jurisprudência da França a autoria da teorização do abuso de direito ${ }^{659}$. Afinal, "as decisões judiciais francesas - esparsas e assistemáticas - não seriam bastantes à elaboração de uma teoria científica", nem permitiriam "fazer surgir um estudo aprofundado sobre a matéria, podendo, no máximo, despertar na doutrina a percepção da necessidade da elaboração de uma teoria relativa àquele instituto" 660.

Nesse mesmo sentido é a lição de PASCAL ANCEL e ClAUde DidRY ${ }^{661}$, para os quais as poucas decisões francesas que versavam o assunto só foram “descobertas” após a

\footnotetext{
${ }^{658}$ No original: Art. 544. La propriété est le droit de jouir et disposer de choses de la manière la plus absolue, pourvu qu'on n'em fasse pás usage prohibé par lois ou par les règlements.

${ }^{659}$ Segundo a crítica de LIMONGI FRANÇA, seria hábito dos autores franceses atribuir à jurisprudência do seu país a sistematização de institutos já desenvolvidos alhures, sendo o abuso de direito apenas mais um deles (Op. cit., p. 42).

${ }^{660}$ EdUARDO JORDÃO. Repensando a Teoria... Op. cit., p. 61.

661 "L'apparition de la notion d'abus em droit français au debut du XXème siècle". In: L'abus de droit, comparaisons franco-suisses. Saint-Étienne: Université de Saint-Étienne, 2001, p. 55; tradução livre; No original: "Il semble donc vraiment excessif d'affirmer que la notion d'abus de droit est une création de la jurisprudence du XIXe siècle. Em réalité, même si on en découvre quelques traces, c'est la doctrine qui, a en quelque sorte 'récupéré' a posteriori les quelques décisions antérieures pour donner l'impression d'un corpus jurisprudentiel préexistant. Lei comme ailleurs, la jurisprudence est très largement le produit d'une construction doctrinale".
} 
elaboração doutrinária das teorias sobre o abuso de direito, servindo-lhes meramente para reforçá-las:

\begin{abstract}
"parece realmente excessivo afirmar que a noção de abuso de direito é uma criação da jurisprudência do século XIX. Na realidade, mesmo se nela descobrimos alguns traços, é a doutrina que de alguma forma tem recuperado a posteriori algumas decisões anteriores para dar a impressão de um corpo jurisprudencial pré-existente. Aqui como alhures, a jurisprudência é em grande parte o produto de uma construção doutrinária."
\end{abstract}

Em arremate, EDUARDO JORDÃO ${ }^{662}$ destaca que, muitos anos antes daquelas decisões, o Código prussiano de 1794 já previa - e reprimia - o exercício abusivo do direito, estabelecendo que:

"aquele que exerce o seu direito no interior de seus limites próprios, não está obrigado a reparar o dano que resulte para outro. Mas deve repará-lo quando resulta claramente que, dentre vários modos possíveis de exercer seu direito, elegeu o mais danoso, com a intenção de prejudicar" (...) "ninguém pode abusar de sua propriedade para lesionar outrem ou prejudicá-lo".

De qualquer forma, em que pesem as discussões (e dúvidas) sobre as primeiras tentativas de sistematização do instituto, há certo consenso de que a teoria sobre o abuso do direito começou efetivamente a tomar corpo no início do século $\mathrm{XX}$, com os trabalhos de PORCHEROT (De l'abus de droit, 1901), JOSSERAND (L'abus des droits, 1905), RIPERT (L'exercice des droits et la responsabilité civile, 1905), DESSERTEAUX (Abus de droit ou conflit de droits, 1906) e VALLET (L'exercice fautif de droits, 1907), entre outros ${ }^{663}$.

No Brasil, creditam-se os primeiros trabalhos sobre o tema a JORGE AMERICANO (Do abuso de direito no exercício da demanda, 1923), PEDRO BAPTISTA MARTINS ( $O$ abuso do direito e o ato ilícito, 1935) ${ }^{664} \mathrm{e}$, um pouco mais recentemente, Everaldo Cunha Luna (Abuso de Direito, 1959).

\footnotetext{
${ }^{662}$ Repensando a Teoria... Op. cit., p. 60.

${ }^{663}$ Cf. PonTES DE MiRAndA. Tratado... Op. cit., t. 53, p. 64 e EdUARdo Jordão. Repensando a Teoria... Op. cit., p. 63.

${ }^{664}$ Os anos mencionados referem-se à $1^{\text {a }}$ edição de cada uma dessas obras.
} 


\subsection{As principais teorias sobre o abuso do direito}

Já na década de 1920, CLóvis BEVILAQUA ${ }^{665}$ destacava haver inúmeras teorias sobre o abuso do direito. Outras tantas seriam formuladas ao longo do século XX, sendo impressionante a dimensão e a diversidade das discussões sobre o indigitado instituto, que mereceu a atenção dos principais juristas.

EDUARDO JORDÃO ${ }^{666}$ propôs interessante classificação dessas teorias a partir do conceito fundamental que fazem da figura do abuso do direito, deixando de lado as peculiaridades e divergências dos doutrinadores pertencentes à mesma corrente.

Haveria para ele a "teoria tradicional", a "teoria do conflito de direitos", a "teoria do conflito de sistemas", a "teoria do abuso como violação da função social do direito subjetivo" e, finalmente, a "teoria do abuso como violação do princípio da boa-fé", conforme explicado a seguir:

\subsubsection{Teoria tradicional}

Para a "teoria tradicional" - assim chamada por ter sido o ponto de partida para as demais -, o abuso do direito consistira no ato que, embora conforme ao direito subjetivo (assim entendida a faculdade individual de demandar o direito decorrente da norma), é, ao mesmo tempo, contrário ao direito objetivo.

Essa teoria, defendida por JOSSERAND ${ }^{667}$, encontrou especial oposição de PlANIOL, que com razão entendia que, sendo o ato contrário ao direito objetivo, logicamente não haveria direito subjetivo, pois este decorre daquele. Equivocado, pois, falar-se em direito subjetivo em violação do correspondente direito objetivo.

665 "Pensam uns que o abuso do direito está seu exercício, com intenção de prejudicar alguém (BUFNOIR, SOURDAT, CHARMONT); entendem outros que elle se caracteriza pela ausência de motivos legítimos (JOSSERAND, GÉNY); CAPITANT associa a negligência ou imprudência à intenção de prejudicar; SALEILLES acha que o abuso do direito está no seu uso anormal; BARDESCO pensa que as diversas fórmulas propostas são insufficientes, mas se completam e devem ser aceitas até que, mais firme o estado jurídico por ellas representado, se possa traduzir por um critério único; KOHLER considera o abuso do direito uma offensa à personalidade." (Código Civil dos Estados Unidos do Brasil. 3 ed. Rio de Janeiro: Livraria Francisco Alves, 1927, v. 1, p. 423.

${ }^{666}$ Repensando a Teoria... Op. cit., p. 65-98.

${ }^{667}$ De l'esprit de droits et de leur relativité: théorie dite de l'abus des droits. 2 ed. Paris: Dalloz, 1939. 
PLANIOL ${ }^{668}$ questionava até mesmo a expressão "abuso do direito", porquanto desprovida de sentido: "a fórmula "uso abusivo de direito" é uma logomaquia, porque se uso do meu direito, meu ato é lícito; e quando é ilícito, é porque já ultrapassei meu direito e passo a agir sem direito". "Le droit cesse ò l'abus commence" (o direito termina onde começa o abuso), dizia o autor ${ }^{669}$.

Ainda assim, não obstante as suas falhas e incongruências, a chamada teoria tradicional foi muito importante para fomentar as discussões em torno do abuso do direito, notadamente para o desenvolvimento das teorias seguintes.

\subsubsection{Teoria do conflito de direitos}

Outra teoria, contemporânea à "tradicional", foi sustentada por MARC DESSERTEAUX $^{670}$, para quem "o abuso do direito consiste em lesar um outro direito igualmente respeitável", o que em boa terminologia significaria um "conflito de direitos".

No Brasil, essa posição foi acolhida por José DE AGUIAR DiAs ${ }^{671}$. Amparado na lição de PONTES DE MIRANDA, o autor defendia existir, em todas as sociedades, uma regra moral elementar, de conteúdo mais amplo do que o do princípio da liberdade individual, sendo limitativa das faculdades que o exercício desta (liberdade individual) comporta.

Daí que, para a "teoria do conflito de direitos", o abuso do direito seria "todo ato que, autorizado em princípio, legalmente, se não conforme, ou em si mesmo ou pelo modo empregado, a essa limitação. Há, ninguém duvida, um direito de prejudicar. Mas, para que se possa exercer, é preciso estar autorizado por interesse jurídico-social prevalente, em relação ao sujeito passivo da ação prejudicial”. ${ }^{672}$

\footnotetext{
${ }^{668}$ Traité élémentaire de droit civil. 4 ed. Paris: Librairie Géneraçe de Droit \& de Jurisprudence, 1907, t. 2, p. 281, tradução livre. No original: "sa formule 'usage abusif des droit' est une logomachie, car si j'use de mon droit, mon acte est licite; et, quand Il est illicite, c'est que jê dépasse mon droit et que j'agis sans droit".

${ }^{669}$ A respeito do debate entre Planiol e Josserand, confira-se Jorge MANUEl Coutinho DE ABREu. Do abuso de direito. Coimbra: Almedina, 1983, p. 45-47.

670 “Abus de Droit ou Conflit de Droits”. Revue Trimestrielle de Droit Civil, 1906, p. 124; tradução livre. No original: "C'est que l'abus de droit consiste à léser un autre droit également respectable, et mériterait en bonne terminologie d'être appelé le conflit de droits".

${ }^{671}$ Da Responsabilidade Civil. 4 ed. Rio de Janeiro: Forense, 1960, t. 2, p. 523-531.

${ }^{672}$ José DE Aguiar Dias. Da Responsabilidade Civil. 4 ed. Rio de Janeiro Forense, 1960. t. 2, p. 527-528.
} 
A teoria nega, pois, que o abuso do direito implique violação do direito objetivo. Embora conforme a ele, e ao próprio direito subjetivo, o ato abusivo seria antijurídico na medida em que fere outro direito de maior relevância social:

"A idéia é a de que o sujeito, ao exercer o seu direito, deve cuidar para não causar danos ou violar direitos alheios. Se isso acontecer, deve-se proceder a uma ponderação a respeito de qual dos dois direitos (o exercido ou o violado) teria maior relevância social" ${ }^{173}$.

Eis a síntese da teoria do conflito de direitos.

\subsubsection{Teoria do conflito de sistemas}

A teoria do "conflito de sistemas" era sustentada, entre outros, por PEDRO BAPTISTA MARTINS ${ }^{674}$. Apesar das várias diferenças entre os entendimentos desses e outros autores, todos mais ou menos concordam que o abuso do direito seria juridicamente lícito, por não encontrar vedação no ordenamento, mas o seu exercício seria reprimido por razões de ordem meta-jurídica, de natureza moral ou social, que estariam na consciência dos povos.

O abuso ocorreria, assim, quando houvesse conflito entre o sistema legal e a moral, circunstância bastante para obstar a prática do ato, ainda que juridicamente lícito, ou seja, mesmo que expressamente permitido (ou não vedado) pelo ordenamento vigente.

\subsubsection{Abuso como violação da função social do direito subjetivo}

Uma outra teoria - também calcada nas ideias de JOSSERAND -, funda-se na concepção (hoje amplamente difundida) de que o direito subjetivo não se constitui apenas das faculdades outorgadas ao seu titular, mas igualmente de deveres, inerentes à sua função social.

\footnotetext{
${ }^{673}$ EDUARDO JORDÃO. Repensando a Teoria... Op. cit., p. 72.

${ }^{674}$ O abuso do direito e o ato ilícito. 2 ed. Rio de Janeiro: Freitas Bastos, 1941, p. 205.
} 
Não sendo o direito um fim em si mesmo, aquele que o exerce deve respeitar a finalidade social para a qual tal direito foi conferido. Quer isso dizer que, além de atender ao próprio interesse, deverá razoavelmente respeitar o interesse geral (o interesse social), pautando-se em critérios de boa-fé, justiça e equidade.

Assim, ao exercer um direito descuidando-se da sua função social (isto é, da sua finalidade social e daqueles deveres inerentes ao próprio direito), o titular estaria agindo abusivamente e, portanto, de forma ilícita:

"todo o direito tem uma função social da qual seu titular não se pode evadir sem cometer delito que tem um nome: o abuso do direito" ${ }^{\text {675 }}$.

A aplicação dessa tese - em parte acolhida pelo Código Civil de 2002, como se verá adiante - causa problemas sérios, sobretudo porque o conceito de "função social" é extremamente vago, aceitando significativas influências de cunho político-ideológico ${ }^{676}$. “A específica função social dos direitos subjetivos em uma ordem jurídica dependerá dos valores nela inscritos e das opções feitas pela sociedade que vige sob sua égide" 677 .

\subsubsection{Abuso como violação do princípio da boa-fé}

Para esta outra teoria, a boa-fé objetiva - hoje positivada no Código Civil brasileiro (arts. 113, 187 e 422) - constitui princípio integrante de todos os ordenamentos jurídicos, sendo balizadora do exercício dos direitos subjetivos.

O abuso do direito se materializaria, assim, nos atos que descuidassem da boafé, definida por JUDITH MARTINS-CostA ${ }^{678}$ como “o standard de lisura, correção, probidade, lealdade, honestidade - enfim, o civiliter agere que deve pautar as relações intersubjetivas regradas pelo Direito", atuando concomitantemente enquanto "(i) fonte de

${ }^{675}$ JOSSERAND. De l'esprit de droits... Op. cit.. p. 322, tradução livre. No original: "Tout droit a une fonction dont son titulaires ne peut s'évader qu'en commettant un délit qui a nom: l'abus du droit”.

${ }^{676}$ A história registra que a bandeira da função social já foi empregada para as mais variadas finalidades, como, por exemplo, para justificar a desapropriação de fábricas pelo regime nazista alemão.

${ }^{677}$ EDUARDO JORDÃO. Repensando a Teoria... Op. cit., p. 88

678 "Os avatares do Abuso do direito e o rumo indicado pela boa-fé”. In: DELGADO, Mário Luiz; ALVES, Jones Figueirêdo. Novo Código Civil: questões controvertidas. São Paulo: Método, 2007, p. 530. 
deveres de conduta (deveres de prestação e deveres de proteção) no terreno obrigacional; (ii) cânone para a interpretação dos negócios jurídicos; e (iii) baliza para a averiguação da licitude no modo de exercício de direitos, vedando, por exemplo, o comportamento contraditório ou desleal”.

\subsection{O abuso no Código Civil de 1916}

Mesmo na vigência do Código Civil de 1916, que não lhe fazia menção expressa, a doutrina e a jurisprudência brasileiras já identificavam no ordenamento pátrio a figura do abuso do direito.

Faziam-no mediante interpretação "contrario sensu" do art. 160, I, do referido diploma - que dispunha não constituir ato ilícito o ato praticado em exercício regular de um direito reconhecido ${ }^{679}$ - conjugada com o art. $5^{\circ}$ da Lei de Introdução ao Código Civil $^{680}$, segundo o qual, na aplicação da lei, o juiz atenderá aos fins sociais a que ela se dirige e às exigências do bem comum.

A doutrina pátria dividia-se, contudo, entre os que identificavam o abuso apenas na ação culposa (em especial no direito exercido com o só propósito de prejudicar terceiros, sem nenhum benefício legítimo para o seu titular) e aqueles que o reconheciam em quaisquer situações que, sob o aspecto objetivo, caracterizasse antissociabilidade.

Para os adeptos da primeira teoria, que tinha em CARVALHO SANTOS ${ }^{681}$ um dos seus maiores expoentes, a configuração do abuso dependia do elemento subjetivo, manifestado tanto pelo espírito de emulação ${ }^{682}$ ( o animus nocendi), quanto pelo exercício do direito de forma anormal (contrária às suas finalidades), em decorrência de qualquer modalidade de culpa:

\footnotetext{
${ }^{679} \mathrm{Na}$ lição de Clóvis BeVILAQUA: "Estatue o art. 160, I, que não constitui ato ilícito o praticado no exercício regular de um direito reconhecido. A contrario sensu, o praticado em exercício não regular de um direito, é ilícito. Eis aí a condenação do abuso do direito" (Código Civil dos Estados Unidos do Brasil... Op. cit., p. 422).

${ }^{680}$ Atualmente denominada "Lei de Introdução às Normas do Direito Brasileiro".

${ }^{681}$ Código Civil brasileiro interpretado: Parte Geral (Arts. 144-179). Rio de Janeiro: Livraria Freitas Bastos, 1956. v. 3, p. 355.

${ }^{682}$ Cf. Silvio Rodrigues, “a idéia de que existe abuso do direito na concepção subjetiva de tal teoria, segundo a qual ele ocorrerá quando o ato for estribado no mero propósito de prejudicar, é uma idéia aceita por todos os escritores e se inspira na parêmia malitiis non est indulgendum" (Curso de direito civil. 3 ed. São Paulo: Saraiva, 1977, v. 4, p. 53).
} 
"Por onde se vê que não é bastante a simples existência de prejuízo para haver indenização. Sendo preciso, mais, que o exercício do direito tenha sido anormal, afastando-se do destino econômico ou social a que está vinculado. Verdade incontestável, porém e que Saleilles não contesta, antes confirma, é que tal anormalidade não resulta apenas da intenção de prejudicar, podendo igualmente ter origem por culpa do titular do direito, em qualquer de suas modalidades. Aliás, desnecessário se nos afigura buscar na doutrina a solução desse ponto da questão, pois, como já deixamos evidenciado, em face do nosso Código, não pode haver dúvida de que o abuso de direito pode resultar também na culpa, como qualquer ato ilícito. $\mathrm{O}$ Código brasileiro contenta-se com o exercício anormal do direito, vale dizer - o direito exercido ou com dolo, ou com negligência, ou com imprudência."

Por outro lado, segundo a teoria objetiva - defendida, entre outros, por SILVIO Rodrigues $^{683}$, CAio Mário da Silva Pereira ${ }^{684}$ e Pedro BAPtista Martins ${ }^{685}$-, o que qualifica o abuso do direito é o aspecto objetivo do ato, caracterizado pela desconformidade social. Haverá então abuso de direito, independentemente de culpa, "quando o seu titular o utiliza em desacordo com a finalidade social para a qual os direitos subjetivos foram concedidos ${ }^{\text {} 686}$.

Conforme CAIO MÁRIO DA SILVA PEREIRA ${ }^{687}$, “estruturada a teoria do abuso de direito como instituto autônomo, marchar-se-á para o critério de apuração objetiva”, respondendo por perdas e danos "o titular do direito que o exercer além dos limites da normalidade ou regularidade, causando dano a outrem, independentemente de penetrar no psiquismo do sujeito, e de indagar se seu propósito ou de sua consciência do dano

\footnotetext{
${ }^{683}$ Curso de direito civil. 3 ed. São Paulo: Saraiva, 1977, v. 4, p. 55. Discorda-se da opinião de HuMBERTo THEODORO JÚNIOR acerca do pensamento de SILVIO RODRIGUES, que entende ter este autor se filiado a corrente subjetivista (In: TEIXEIRA, Sálvio de Figueiredo (Coord.). Comentários ao Novo Código Civil. 2 ed. Rio de Janeiro: Forense, 2003. v. 3, t. 2, p. 118). Fica bem clara a opção de Silvio Rodrigues pela teoria objetiva quando, depois de descrevê-la, conclui "ter sido essa concepção de abuso abraçada pelo legislador pátrio" (op. cit., p. 55). Mesma conclusão, aliás, constante de edição publicada após o advento do Código Civil de 2002 (19 ed., 2002, p. 52).

${ }^{684}$ Responsabilidade civil. 7 ed. Rio de Janeiro: Forense, 1996, n. 211, p. 258.

685 “a consagração da doutrina do abuso de direito é, portanto, expressa, assentando-se a fórmula numa base puramente objetiva. O destinatário de um direito subjetivo, que o exerce de maneira anormal, desnaturalizando-lhe os institutos econômicos ou sociais, envolve a sua responsabilidade e sujeita-se à obrigação de reparar as consequiências de seu ato abusivo" ( $O$ abuso do direito e o ato ilícito. 2 ed. Rio de Janeiro: Freitas Bastos, 1941, p. 85).

${ }^{686}$ Silvio Rodrigues. Curso de direito civil. 19 ed. São Paulo: Saraiva, 2002, v. 4, p. 51.

${ }^{687}$ Caio Mário Da Silva Pereira. Direito Civil - Alguns aspectos de sua evolução. Rio de Janeiro: Forense, 2001, p. 258.
} 
causado”. Por conseguinte, "bastaria verificar se o titular do direito o exerceu excedendo os limites impostos pela destinação econômica ou social dele”.

\subsection{O abuso no Código Civil de 2002}

Diferentemente da lei de 1916, o Código Civil de 2002 refere-se expressamente à figura do abuso de direito, reputando ilícito o ato cometido pelo titular que, "ao exercêlo, excede manifestamente os limites impostos pelo seu fim econômico ou social, pela boafé ou pelos bons costumes" (art. 187).

Inspirado nos Códigos Civis de Portugal ${ }^{688}$ e da Grécia ${ }^{689}$, o art. 187 do Código Civil de 2002 tem sofrido crítica de parte da doutrina por ter definido o abuso de direito como espécie de ato ilícito ${ }^{690}$, o que faria condicioná-lo à existência do elemento culposo $^{691}$, vinculado à teoria subjetiva:

"a ultrapassada concepção do abuso de direito como forma de ato ilícito, na prática, condicionava sua repressão à prova de culpa, noção quase inerente ao conceito tradicional de ilicitude" ${ }^{\prime 692}$.

Segundo GUSTAVO TEPEDINO ${ }^{693}$, essa opção do legislador contraria a doutrina mais moderna, que procura conferir ao instituto papel autônomo na ciência jurídica, sem

\footnotetext{
${ }^{688} \mathrm{O}$ art. $334^{\circ}$ do Código Civil português, no entanto, não se refere à ilicitude do ato, mas à ilegitimidade do seu exercício: "É ilegítimo o exercício de um direito, quando o titular exceda manifestamente os limites impostos pela boa fé, pelos bons costumes ou pelo fim social ou económico desse direito".

${ }^{689}$ Art. 281 do Código Civil grego.

${ }^{690}$ Em sentido contrário, JOSÉ AUGUSTO DELGADO afirma que "essa equiparação do abuso de direito a verdadeiro ato ilícito feita pelo artigo 187, tem sido muito aplaudida pela doutrina, por consolidar, na via legislativa, entendimento que há muito vinha sendo defendido". (In: ALVIN, Arruda; WAMBIER; Teresa Alvim. (coords.) Comentários ao Código Civil brasileiro: dos fatos jurídicos. Rio de Janeiro: Forense, 2008, v. 2, p. 855).

${ }^{691}$ Nesse sentido, HUMBERTO THEODORO JÚNIOR afirma: "Nosso direito positivo atual não dá ensejo a dúvidas: adotou claramente a orientação preconizada pela teoria subjetivista do abuso de direito. Primeiro definiu o ato ilícito absoluto, como fato humano integrado pelo elemento subjetivo (culpa) (art. 186). Em seguida, qualificou ... o exercício abusivo de direito como ato ilícito (art. 187). ... Em nosso ordenamento jurídico, destarte, é o elemento intencional, consistente no animus nocendi (intenção de prejudicar que provoca a transformação de um direito em ato ilícito), ou pelo menos o elemento subjetivo culpa lato sensu." (Comentários... Op. cit., p. 118-119).

${ }^{692}$ Cf. Gustavo TePedino [et. al.]. Código Civil interpretado. Rio de Janeiro: Renovar, 2004, v. 1, p. 342.

${ }^{693}$ Idem, p. 342.
} 
identificá-lo com o conceito de ilicitude, em sentido estrito. Afirma ele que "no direito civil contemporâneo ... a aferição da abusividade no exercício de um direito deve ser exclusivamente objetiva, ou seja, deve depender tão-somente da verificação de desconformidade concreta entre o exercício da situação jurídica e os valores tutelados pelo ordenamento civil-constitucional”.

Assim é que, não obstante a redação do art. 187, tem-se compreendido a "ilicitude" nele referida em sentido amplo, como uma "antijuridicidade sui generis no resultado"694. O dispositivo conteria, pois, "referência a uma ilicitude lato sensu, no sentido de contrariedade ao direito como um todo, e não como uma identificação entre a etilogia do ato ilícito e a do ato abusivo, que são claramente diversas „695

Prova desse entendimento é o Enunciado $\mathrm{n}^{\circ} 37$ do Centro de Estudos Judiciários da Justiça Federal: "a responsabilidade civil decorrente do abuso de direito independe de culpa, e fundamenta-se somente no critério objetivo-finalístico”.

Outra crítica que se faz ao art. 187 refere-se ao emprego do advérbio "manifestamente", que enseja dúvida sobre o alcance do dispositivo, como pondera HELOÍSA CARPENA "696. "somente será abusivo o ato que excede exageradamente os limites ou basta que tal excesso seja ostensivo, facilmente notado?”.

A mesma autora conclui - com razão - que tal circunstância não é elemento do ato abusivo, bastando a "inobservância dos limites axiológicos para caracterizá-lo, sem contemplação de sua extensão ou evidência”.

Assim, na égide do código vigente, o abuso do direito é "ato lícito pelo conteúdo, ilícito pelas conseqüências, tendo natureza jurídica mista - entre o ato jurídico e

\footnotetext{
${ }^{694}$ Cf. MARIA Helena DinIZ. In: FiUZA, Ricardo (coord. até a $5^{\mathrm{a}}$ ed.); TAVARES DA SILVA, Regina Beatriz

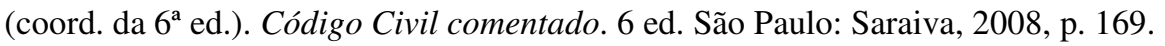

${ }^{695}$ Cf. Gustavo TePedino. Código Civil interpretado... Op. cit., p. 342.

696 “O abuso de direito no Código Civil de 2002: relativização de direitos na ótica civil constitucional”. In: TEPEDINo, Gustavo (coord.). A parte geral do novo Código Civil: estudos na perspectiva civil constitucional. 3 ed. Rio de Janeiro: Renovar, 2007, p. 416-417.
} 
o ato lícito - situando-se no mundo dos fatos jurídicos em sentido amplo"697, definindo-o MARIA HELENA DinIz" ${ }^{698}$ como o exercício que, "sob a aparência de um ato legal ou lícito, esconde a ilicitude no resultado, por atentado ao princípio da boa-fé e aos bons costumes ou por desvio de finalidade socioeconômica para a qual o direito foi estabelecido”.

\section{Abuso do direito de voto}

Como já explicado no Capítulo III, item 9, as deliberações da AssembleiaGeral são formadas a partir do voto dos credores. $\mathrm{O}$ voto, por sua vez, corresponde tanto à manifestação de vontade do credor como ao direito que lhe é outorgado para influir na solução a ser dada à crise do devedor comum, isto é, o direito de concorrer para formação da deliberação assemblear, que vinculará todos os participantes, mesmo dissidentes ou ausentes, ressalvadas as exceções legais já tratadas.

O voto, portanto, não se confunde com um acordo privado entre credor e devedor, porquanto afeta (ou tem o potencial de afetar) todos aqueles que se sujeitam ao processo concursal, e não apenas diretamente, como ocorre com os demais credores, mas também indiretamente, eis que as decisões tomadas na AGC repercutem sobre todos os que dependem de algum modo do devedor, inclusive a própria sociedade.

Note-se que o poder conferido ao credor, expressado através do voto, não se fundamenta apenas na sujeição jurídica do devedor decorrente da obrigação por ele contraída, tanto que capaz de atingir a esfera jurídica de outros credores, com os quais não tem relação contratual alguma.

Na verdade, num sistema de negociação estruturada (structured bargaining), o poder dado aos credores é parte do mecanismo concebido para solucionar a crise da empresa de forma eficiente, segundo a ideia de que a negociação entre eles e com o devedor, quando realizada de acordo com a estrutura legal, tende a produzir comportamentos cooperativos, de convergência de interesses, em lugar do comportamento

\footnotetext{
${ }^{697}$ Cf. FLÁvio TARTUCE, a partir das lições de Limongi França (“Considerações sobre o abuso de direito ou ato emulativo civil". In: Delgado, Mário Luiz; ALVES, Jones Figueirêdo. Novo Código Civil: questões controvertidas. São Paulo: Método, 2004, p. 92).

${ }^{698}$ Código Civil comentado... Op. cit., p. 169.
} 
individualista. "Confia-se que desse processo de negociação estruturada (regulada pela lei) possa resultar a solução consentânea com o interesse público na preservação da empresa viável e na liquidação da empresa inviável"699, de modo que o voto se coloca, sob uma perspectiva funcional, a serviço daqueles objetivos dispostos nos arts. 47 e 75 da LRF e que se traduzem no princípio da preservação da empresa ${ }^{700}$.

Essa seria, segundo entendemos, a justificativa para a imposição da vontade da maioria sobre a minoria, e não propriamente um "interesse comum" dos credores, de incerta definição e de duvidosa existência num ambiente para o qual os participantes são arrastados involuntariamente e onde não há um objetivo predeterminado a ser perseguido (diferentemente, portanto, do que se passa numa sociedade).

A partir daí, desse duplo fundamento (o crédito propriamente dito e a subordinação a um sistema que persegue a eficiência e o atendimento da função social da empresa), talvez seja possível, à luz do caso concreto, estabelecer um padrão de comportamento, a fim de identificar o abuso daqueles participantes ${ }^{701}$ que, no exercício do direito de voto, desviem desse padrão, produzindo resultados desconformes aos princípios e valores da lei ${ }^{702}$.

Foge do escopo deste trabalho analisar a fundo todas as nuances do abuso do direito de voto do credor (tema que merece, sem dúvida, um estudo aprofundado e particular). Aqui nos limitamos a fazer apenas alguns breves apontamentos sobre os critérios a serem utilizados para a definição do padrão de comportamento referido acima, matéria ainda pouco explorada pela doutrina. É com o espírito de contribuir para o debate

\footnotetext{
${ }^{699}$ EDUARDO SECCHI MUNHOZ. “Anotações sobre os limites do poder jurisdicional na apreciação do plano de recuperação judicial”... Op. cit., p. 191.

${ }^{700}$ Nesse sentido, FÁTIMA NANCY ANDRIGHI leciona que os princípios referidos nos arts. 47 e 75 da lei "em verdade, poderiam ser resumidos em um único e maior princípio de todo o direito empresarial: a conservação da empresa". CORRÊA-LIMA, Osmar Brina; e LIMA, Sérgio Mourão Correa (coord.). Comentários à nova Lei de Falência e Recuperação de Empresa. Rio de Janeiro: Forense, 2009, p. 491.

${ }^{701}$ Não apenas dos credores, mas também do próprio devedor.

702 “O voto do credor na assembleia geral também se sujeita, de certa forma, aos princípios comentados. Nesse ponto, é bom notar que o credor vota considerando o seu interesse em receber o crédito. Esse o interesse que legitima seu voto. Não se pode impor a ele a obrigação de aprovar o plano. Mas pode ocorrer eventual abuso no exercício do voto ou conflito de interesses, e esses serão confrontados com as diretrizes da lei.” (ARnOldo WALd e Ivo WAISBERG. In: Comentários à nova Lei de Falência... Op. cit., p. 321).
} 
que serão aqui esboçadas algumas reflexões do autor, sem a pretensão de apresentar respostas definitivas às questões suscitadas.

\subsection{Ato de emulação}

A mais flagrante hipótese de abuso do direito de voto é identificada no ato de emulação, quando o voto é exercido com o só propósito de causar prejuízo a terceiro, sem nenhuma vantagem para o titular do crédito.

O abuso decorrente da emulação difere do abuso não emulativo na medida em que este visa à obtenção de uma vantagem indevida, sendo o prejuízo causado por um reflexo da conduta, um risco assumido pelo agente, mas não necessariamente o objetivo desta. No abuso emulativo, a tônica não está na vantagem indevida mas na imposição do prejuízo, que é o objetivo do ato ${ }^{703}$.

O direito de voto, como os demais direitos, presta-se ao atendimento de certos interesses juridicamente tutelados, entre os quais não se encontram aqueles derivados da má-fé ou que atentam contra os bons costumes.

Assim, se o voto proferido pelo credor resultar apenas em prejuízo ao devedor ou aos demais credores, sem nenhuma vantagem para o titular, nem justificativa econômica ou jurídica para legitimá-lo, caberá ao juiz declarar sua invalidade, por configurar hipótese de abuso de direito.

Note-se que, consoante exposto acima, essa avaliação se faz sob uma perspectiva finalístico-objetiva, sendo irrelevante para a configuração do abuso a intenção do agente, ou mesmo a existência de culpa.

703 Cf. FÁBIO KONDER COMPARATO. "Controle conjunto, abuso no exercício do voto acionário e alienação indireta de controle empresarial”. In: Direito Empresarial. São Paulo: Saraiva, 1990, p. 90-91. 


\subsection{Conflito de interesses}

Na Lei $\mathrm{n}^{\mathrm{o}}$ 11.101/2005 há algo semelhante ao conflito formal ${ }^{704}$ de interesses previsto no art. $115, \S 1^{\circ}$, da Lei das S.A. ${ }^{705}$, no que diz respeito àqueles credores que, embora sujeitos aos efeitos da recuperação judicial ou da falência, são privados do direito de voto por expressa disposição legal.

É o que ocorre, muito especialmente, com os sócios do devedor e as sociedades que com eles mantêm vinculação societária relevante (acima de 10\% do capital social). $\mathrm{O}$ mesmo vale para o cônjuge ou parente até o segundo grau do devedor, seu sócio controlador, seus administradores, membros dos seus conselhos fiscais, consultivos ou semelhantes, e ainda para as sociedades onde tais pessoas exerçam essas funções (LRF, art. 43, caput e parágrafo único).

Para a lei, esses credores confundem-se em certa medida com o próprio devedor, pressupondo-se que as suas ações não seriam determinadas pela condição de credor, mas pelos interesses da empresa sujeita ao processo concursal. Assim, p. ex., ao votarem o plano de recuperação, esses credores não estariam negociando com o devedor; estariam, na verdade, agindo como agentes dos interesses deste, tornando ilegítima a sua participação na deliberação.

Questão de maior relevância diz respeito à verificação do abuso nos casos de conflito material, para os quais não existe regra que exclua a priori o voto do credor. A esse respeito, ERASMO VALLADÃo FrANÇA ${ }^{706}$ escreveu que “a Lei $n^{\circ} 11.101$, infelizmente, não trata da matéria. E não faltarão hipóteses em que o interesse individual de

\footnotetext{
${ }^{704}$ No "conflito formal", há presunção absoluta da existência do conflito de interesses, que impede o próprio exercício do voto; diferentemente do chamado "conflito material", que só se verifica a posteriori, depois de conhecido o sentido do voto.

${ }^{705}$ Recentemente, o Colegiado da Comissão de Valores Mobiliários (CVM) passou a entender que todas as hipóteses previstas no $\S 1^{\circ}$ do art. 155 da Lei das S.A., mesmo aquelas relativas às deliberações que possam beneficiar o acionista de modo particular ou em que tiver interesse conflitante com o da companhia, ensejam conflito formal, impedindo o próprio exercício do voto (Proc. RJ2009/13179, Reg. 7190/10, rel. Diretor Alex Broedel Lopes). Tal entendimento, porém, contraria o entendimento da própria CVM consolidado no Parecer de Orientação $\mathrm{n}^{\circ}$ 34/2006 e vem sendo criticado por parte da doutrina (cf. ALFREDO SÉRGIO LAZZARESCHI NeTO. Lei das Sociedades por Ações anotada... Op. cit., p. 234-236).

${ }^{706}$ In: Comentários... Op.cit., p. 192.
} 
determinado credor poderá ser substancialmente conflitante com o da coletividade, a exigir a anulação da deliberação”.

O autor reputa abusivo o voto exercido pelo credor em conflito com aquilo que denomina de "interesse da comunhão dos credores", retomando a ideia de "vontade coletiva" que serviu para justificar que a AGC seria um órgão dessa comunhão. Inspira-se, sem dúvida, no disposto no art. $115, \S 1^{\circ}$, da Lei das S.A., que proíbe o acionista de votar nas matérias que puderem lhe beneficiar de modo particular, ou em que tiver interesse conflitante com o da companhia.

A analogia feita com a teoria dos conflitos de interesses desenvolvida no direito societário é importante. Contudo, como observa EdUARdo SECCHI MuNHOZ, essa teoria não pode ser transposta para o direito concursal sem profundos temperamentos, vez que se cuida de situações jurídicas absolutamente distintas ${ }^{707}$.

Conforme já identificava TRAJANO DE MIRANDA VALVERDE ${ }^{708}$, “a massa falida não é, como as associações, corporações, fundações, etc., o resultado de um concurso voluntário de indivíduos, com certo objetivo, mas a consequência inevitável da aplicação da lei a determinados atos ou fatos”. Diferentemente do que ocorre numa sociedade, não há um objetivo certo e predeterminado ao qual os participantes aderem voluntariamente. No processo concursal, a submissão dos credores é forçada, inexistindo entre eles um compromisso prévio em prol de um interesse comum e determinado.

Segundo nos parece, a ideia de interesse comum dos credores - que não é nova - relaciona-se com a concepção do direito falimentar enquanto mero instrumento de desapossamento e liquidação dos bens do devedor para pagamento dos credores, segundo uma ordem preestabelecida. Nos primórdios do direito concursal, em que a falência não passava disso, sem maiores sofisticações, não é desarrazoado admitir que os credores tivessem mesmo um interesse comum, de que o procedimento fosse seguido à risca e do modo mais rápido possível, a fim de propiciar o pagamento do crédito o quanto antes e em estrita obediência à par condicio creditorum.

\footnotetext{
${ }^{707}$ Anotações sobre os limites do poder jurisdicional ...”. Op. cit., p. 193.

${ }^{708}$ A Fallencia... Op. cit., v. 1, p. 142.
} 
Com o tempo, porém, o direito concursal foi se tornando cada vez mais complexo, com a criação de mecanismos destinados a evitar a quebra e até permitir a continuação do negócio na falência. À medida que se desenvolveu a concordata, a reestruturação das dívidas e do negócio do devedor passou compreender a intervenção estatal nas convenções privadas com os credores, ao ponto de a decisão tomada por uma maioria ser capaz de alterar as condições dos créditos titularizados por todos.

No âmbito de relações tão complexas, é muito difícil - senão impossível identificar um fio condutor que represente com fidelidade o interesse comum dos credores, máxime porque cada qual não é mais um mero espectador do processo, tomando parte ativamente para a consecução do seu próprio interesse. É da realidade das coisas e da lógica do sistema capitalista que assim o seja; cada um age por si e no próprio interesse, como assinala TRAJANO DE MiRANDA VALVERDE:

“O concurso de credores é um processo legal. Não é possível ver-se nessa concorrência uma associação, embora momentânea, de indivíduos, ou mesmo uma communio incidens, ou qualquer outra espécie de comunhão. (É um termo que também deve ser afastado por gerar ideias erradas sobre o concurso de credores). Cada credor, que no concurso resolve entrar, sabe de antemão quais são os seus direitos e quais as suas obrigações; o que pode e o que não pode fazer. Cada um age por si e no seu próprio interesse, contrariando, se possível, o dos outros concorrentes. Nenhum espírito associativo, mas o conflito de interesses, que a lei procura solucionar, ora pondo de lado os interessados, ora consultando-os pela voz da maioria".

Além disso, não se pode ignorar que, nas sociedades, há regra expressa que determina que "o acionista deve exercer o direito de voto no interesse da companhia" (Lei das S.A., art. 115, caput), estabelecendo um padrão a partir do qual serão examinados os eventuais abusos cometidos através do exercício do voto. No regime concursal, porém, não há regra que defina esse padrão; o que existem são princípios que, ao mesmo tempo em que fundamentam o direito de voto, condicionam-lhe o exercício, sem estar necessariamente ligados a um "interesse comum" dos credores.

Esses princípios estão relacionados, na verdade, à preservação da função social da empresa e à eficiência do procedimento de liquidação, mas não determinam que os credores votem sempre a favor da recuperação ou da falência. O que eles fazem é irradiar 
valores que, à luz do caso concreto, estabelecem, em bases alargadas, alguns parâmetros para o exercício do direito de voto, sem permitir, contudo, a elaboração de uma fórmula rígida para identificar o abuso.

Assim, coloca-se em dúvida a possibilidade de identificar-se o abuso a partir da contraposição entre o interesse particular e o que seria o "interesse comum" de todos os credores. Parece mais adequado falar, não em interesse comum ou coletivo, mas em interesses juridicamente tutelados (vale dizer, interesses que se amoldam aos princípios da lei concursal), em contraposição aos interesses que não contam com amparo legal.

Entre os interesses sem amparo jurídico, pode-se citar o caso do credor que, sendo ao mesmo tempo concorrente do devedor, utiliza-se do voto como instrumento para eliminar a competição. Isso é abuso, em que pese a mera concorrência não impedir o credor de votar, nem ensejar uma presunção absoluta contra si. Na verdade, essa circunstância será levada em conta na análise de eventual desvio de comportamento por parte desse credor, embora não seja por si só determinante para a configuração do abuso.

Por outro lado, vale ressaltar que os interesses juridicamente tutelados não se limitam, como pode parecer, ao recebimento do crédito. É perfeitamente legítimo, p. ex., que os credores trabalhistas votem a favor do plano a visando manutenção dos seus empregos, e não propriamente ao recebimento do seu crédito. Cuida-se de interesse particular, mas juridicamente tutelado, na medida em que se coaduna com o princípio da função social da empresa e seus consectários.

O mesmo vale para certos fornecedores do devedor, para os quais a continuidade da relação comercial é mais importante do que o próprio crédito. Veja-se que, em ambos os casos, o principal interesse não é o recebimento do crédito, mas nem por isso pode ser taxado de ilegítimo (ao menos não abstratamente, pois em conformidade a preservação da empresa).

No entanto, se à luz do caso concreto se verificar que a manutenção da empresa é absolutamente inviável, e que esses credores não querem outra coisa senão obrigar todos os demais a arcar com a postergação do encerramento inevitável da atividade do devedor, então esse mesmo interesse poderá se tornar ilegítimo, ensejando o abuso. 
CAPÍTULO V - CONSIDERAÇÕES FINAIS 


\section{CAPÍTULO V - CONSIDERAÇÕES FINAIS}

A Lei $n^{\circ} 11.101$, de 9 de fevereiro de 2005, estabeleceu novo regime jurídico para a falência e para a recuperação de empresas em crise, retomando - ainda que com diferenças significativas - sistema que vigorou no Brasil na primeira metade do século XX e que é hodiernamente adotado por algumas das principais economias mundiais.

Princípios gerais e informadores da nova legislação são, notadamente, a função social da empresa e a preservação da atividade econômica.

Não obstante esses princípios já constassem do nosso sistema e fossem resguardados pela Constituição Federal (arts. 1 ${ }^{\circ}$, IV, $3^{\circ}$, II e 170, III), a Lei nº 11.101/2005 importou no reconhecimento expresso de sua aplicação ao regime concursal, salientando a relevância da preservação da empresa enquanto fonte produtora de riquezas, geradora de empregos e essencial para o desenvolvimento da atividade econômica.

Nesse contexto se insere o art. 47 da LRF, o primeiro do capítulo destinado especificamente à "recuperação judicial”, que dá a tônica da novel legislação: “ $a$ recuperação judicial tem por objetivo viabilizar a superação da situação de crise econômico-financeira do devedor, a fim de permitir a manutenção da fonte produtora, do emprego dos trabalhadores e dos interesses dos credores, promovendo, assim, a preservação da empresa, sua função social e o estímulo à atividade econômica”.

O princípio da preservação da empresa também informa muito especialmente o art. 75 da LRF, que determina que "a falência, ao promover o afastamento do devedor de suas atividades, visa a preservar e otimizar a utilização produtiva dos bens, ativos e recursos produtivos, inclusive os intangíveis, da empresa”. Por isso, FÁTIMA NANCY ANDRIGHI $^{709}$ leciona que os princípios referidos nos arts. 47 e 75 da lei "em verdade, poderiam ser resumidos em um único e maior princípio de todo o direito empresarial: a conservação da empresa”.

\footnotetext{
${ }^{709}$ In: Comentários à nova Lei de Falência... Op. cit., p. 491.
} 
Daí ter causado certa perplexidade o fato de a mesma lei, rompendo com a sistemática instaurada pelo Decreto-Lei $\mathrm{n}^{\circ}$ 7.661/45, ter atribuído aos credores a competência para decidir sobre a viabilidade ou inviabilidade da empresa devedora, uma vez que agem premidos por seus interesses individuais ${ }^{710}$ - como é de se esperar num regime capitalista - e não visando aos elevados princípios da lei.

A opção é explicada em razão dos fatores econômicos e políticos que influenciaram a edição da Lei $n^{\circ} 11.101 / 2005$, em especial as pressões exercidas pelo Fundo Monetário Internacional (o FMI) - e os compromissos para com ele assumidos pelo Poder Executivo - a fim de que o Brasil adotasse os chamados principles and guidelines do Banco Mundial ${ }^{711}$.

Essas pressões venceram até o Relator do projeto da nova lei falimentar, Deputado OsvaLdo BIOLCHI ${ }^{712}$, abertamente contrário ao modelo que acabou prevalecendo: "Confesso em sã consciência a você leitor e ao público em geral que, na qualidade de relator, sempre fui refratário à idéia de depositar nas mãos dos credores esta importante decisão da vida das empresas e o próprio destino. Aliás, este sempre foi tema defendido pelo Professor Rubens Requião. Entretanto, o Poder Executivo é que está com a caneta na mão e detém, em qualquer nação do mundo, a supervisão, e, logicamente, poderá impor sua ideologia e filosofia ao Poder Legislativo.”.

De qualquer forma, apesar das várias objeções levantadas, fato é que a lei vigente fez ressuscitar o modelo abandonado pelo Decreto $\mathrm{n}^{\circ}$ 7.661/45, dando-lhe roupagem mais moderna, de acordo com as "melhores práticas" definidas por organismos

\footnotetext{
${ }^{710} \mathrm{Na}$ exposição de motivos do Decreto-Lei $\mathrm{n}^{\mathrm{o}} 7.661 / 45$, subscrita pelo Ministro Alexandre Marcondes, constou justamente o seguinte: "É peculiar ao instituto, no direito vigente, a imposição da deliberação da maioria sobre a vontade dos dissidentes. O sistema, entretanto, não produz os resultados que seriam de desejar. A preponderância da maioria, nas deliberações coletivas, somente se legitima quando todas as vontades deliberantes se manifestem, tendo em vista o interesse comum que as congregou. Ora, nas concordatas formadas por maioria de votos, os credores deliberam sob a pressão do seu interesse individual, deturpando o interesse coletivo da deliberação e tornando ilegítima a sujeição da minoria. E a verdade é que, na vigência desse sistema, se tem verificado a constância dessa anomalia, através dos entendimentos externos do processo, o que importa na quebra da igualdade de tratamento dos credores, princípio informativo do processo falimentar. Atendendo a esse princípio, consagra a concordata como favor concedido pelo juiz, cuja sentença substitui a manifestação da vontade dos credores na formação do contrato....".

${ }^{711}$ Cf. Mauro Rodrigues Penteado. In: Comentários... Op. cit., p. 57-59.

${ }^{712}$ In: Comentários... Op. cit., p. 47
} 
internacionais, que privilegiam a solução negociada entre o devedor e seus credores, para a superação da crise econômico-financeira da empresa.

Segundo esse sistema, faculta-se aos credores participar de importantes decisões que envolvem a empresa em crise, seja para permitir a recuperação do devedor, determinar a forma de liquidação dos seus bens, ou ainda para resolver qualquer outra matéria que possa afetar os seus interesses. Portanto, a solução para a crise da empresa passou a se sujeitar à vontade dos credores, a ser definida no âmbito da Assembleia-Geral, cujas deliberações vinculam todos os participantes, inclusive os dissidentes ou ausentes.

Confere-se aos credores o poder de decisão sob o pressuposto de que, num processo de negociação estruturada (structured bargaining), os participantes tendem a adotar um comportamento cooperativo, de convergência de interesses, em lugar do individualismo. Enfim, "confia-se que desse processo de negociação estruturada (regulada pela lei) possa resultar a solução consentânea com o interesse público na preservação da empresa viável e na liquidação da empresa inviável"713.

Note-se que a lógica da negociação estruturada é estabelecer um equilíbrio entre o devedor e o credor, bem como entre os próprios credores, de modo a produzir resultados legítimos e frustrar comportamentos abusivos. A solução para o abuso é, primeiramente, negocial, reservando-se a intervenção da autoridade judicial apenas para o caso de insuperável intransigência de alguns dos participantes.

A lei concursal brasileira, porém, embora tenha se filiado ao sistema da structured bargaining, carece de instrumentos para promover o necessário equilíbrio entre os participantes, além de conter certas aberrações das quais não se tem notícia em outros países que adotam o mesmo modelo.

Como se procurou apontar ao longo deste trabalho, há falhas legislativas que comprometem a eficiência do sistema concursal brasileiro, destacando-se: $1^{\text {o }}$ ) a inexplicável rigidez da distribuição das classes de credores, que enseja a reunião na mesma classe de créditos absolutamente distintos, que ocupam posições diferentes na ordem legal

\footnotetext{
${ }^{713}$ EDUARDO SECCHI MUNHOZ. “Anotações sobre os limites do poder jurisdicional na apreciação do plano de recuperação judicial”... Op. cit., p. 191.
} 
de pagamentos ${ }^{714} ; 2^{\circ}$ ) a vedação absoluta à prorrogação do prazo de suspensão das ações e execuções contra o devedor (a automatic stay), alheia às circunstâncias do caso concreto e às particularidades da macro-empresa ${ }^{715} ; 3^{\circ}$ ) a impossibilidade de aprovação de plano de recuperação que não tenha sido aceito pelo devedor ${ }^{716}$, que vincula a sorte da empresa (e a sua preservação) à vontade do empresário; $4^{\circ}$ ) a exclusão de certos credores dos efeitos da recuperação judicial por conta da chamada "trava bancária", sem explicação econômica ou jurídica plausível; e $5^{\circ}$ ) a inexistência de mecanismo que confira ao juiz a prerrogativa de superar a reprovação do plano de recuperação pela Assembleia, mesmo quando viável, justo e em acordo com o princípio da par condicio creditorum $^{717}$.

Talvez a principal crítica ao "novo" sistema resida mesmo no fato de não ter conferido ao juiz instrumento efetivo para superar a vontade dos credores, quando contrária ao postulado maior da preservação da empresa. De acordo com a Lei $\mathrm{n}^{\circ}$ 11.101/2005, “o juiz está proibido de “conceder” a recuperação judicial se o plano respectivo não contar com a aprovação dos credores", pois "não é o magistrado que emite juízo valorativo sobre a função social da atividade empresarial em crise,"718.

A ausência de tal instrumento acaba produzindo inegável distorção no sistema concursal brasileiro $^{719}$, que não se acha, por exemplo, nos Estados Unidos, onde o deferimento da recuperação também depende (ao menos em princípio) da concordância dos credores. A diferença fundamental é que, no direito americano, o juiz pode superar a rejeição ao plano de recuperação mediante o chamado cram down $^{720}$.

\footnotetext{
${ }^{714}$ Vide Capítulo III, itens 3.2 e 3.3.

${ }^{715}$ Vide Capítulo I, item 3.2.1.1.

${ }^{716}$ Vide Capítulo II, item 3.2.

${ }^{717}$ Vide Capítulo III, item 9.2.1.

${ }^{718}$ Cf. Mauro Rodrigues Penteado. In: Comentários... Op. cit., p. 127.

719 Questão amplamente debatida no II Colóquio Internacional de Recuperação de Empresas e Falências promovido pela National Conference of Banckruptcy Judges (NCBC) e pelo Instituto Brasileiro de Estudos sobre Recuperação de Empresas (IBR), realizado entre os dias 17 e 18 de setembro de 2010 na sede social da Associação Paulista dos Magistrados (APAMAGIS).

720 Sobre a origem da expressão "cram down", CHARLES JORDAN TABB esclarece: “Confimation of a plan over a class dissent is known as cram down of the plan, because the plan is 'crammed down' the throat of the dissenting class" (The Law of Bankruptcy... Op. cit., p. 829). Em vernáculo, a expressão poderia ser traduzida como "forçar goela abaixo" (não muito consentânea, é verdade, com a tradição do nosso direito).
} 
O cram down americano permite ao juiz conceder a recuperação, a despeito da oposição dos credores, desde que o plano rejeitado seja (i) viável (feasible) do ponto de vista legal, técnico e econômico, (ii) justo e equitativo (fair and equitable) - o que significa estrita obediência à ordem de preferência legal (nenhum credor de classe inferior pode receber antes de serem pagos todos os credores que integram classe superior na ordem de preferência) - e (iii) não implique tratamento diferenciado entre os credores de uma mesma classe ou entre classes de mesma hierarquia (unfair discrimination).

O que mais se assemelha ao "cram down" no direito brasileiro é a previsão constante do art. $58, \S \S 1^{\circ}$ e $2^{\circ}$, da LRF, que permite ao juiz conceder a recuperação se alcançado determinado quórum alternativo ${ }^{721}$ de aprovação do plano. Cuida-se, porém, de instrumento legalista, fechado, muito diferente do "cram down" americano, pois "não dá margem ao juiz para a imposição de plano que possa recuperar a empresa a despeito da discordância dos credores" $" 722$.

Justamente por ser extremamente limitada a margem de atuação do magistrado brasileiro, ganha ainda mais importância sua função de controlar a licitude das deliberações dos credores e do exercício do direito de voto, sobretudo para que possa concretizar os princípios e valores que orientam o novo direito concursal.

Caberá ao juiz, por exemplo, proclamar a invalidade do voto de credor proferido em desobediência a alguma formalidade essencial, em fraude à lei imperativa, ou resultante de vontade viciada. Por outro lado, deverá igualmente rejeitar o voto exercido de forma abusiva, excedendo os limites impostos pelo seu fim econômico ou social, pela boafé ou pelos bons costumes ${ }^{723}$.

\footnotetext{
${ }^{721}$ Nesse sentido, EdUARDO SECCHI MUNHOZ afirma que o "cram down" brasileiro "não depende de fatores relacionados com a efetiva possibilidade de recuperação da empresa", mantendo o poder de decisão com a assembléia-geral de credores. Configura, pois, nada mais do que "um quórum alternativo de aprovação do plano", pois não faculta ao juiz a apreciação concreta da situação econômico-financeira do devedor (In: Comentários... Op. cit., p. 286).

${ }^{722}$ Cf. Alberto CAmiÑa Moreira. In: Direito falimentar e a nova Lei de Falências e Recuperação de Empresas... Op. cit., p. 259.

${ }^{723}$ A esse respeito, confira-se PAULO F. C. SALLES DE TOLEDO, "Recuperação judicial - sociedades anônimas debêntures - assembléia geral de credores - liberdade de associação - boa-fé objetiva - abuso de direito - cram down - par condicio creditorum." Revista de Direito Mercantil, Industrial, Econômico e Financeiro, São Paulo, n. 142, p. 263-281, 2006.
} 
Como o fim social e econômico do direito de voto está inegavelmente relacionado à preservação da função social da empresa ${ }^{724}$ (princípio maior da lei a que os credores também se sujeitam), o reconhecimento do abuso do direito poderá constituir fundamento para que o juiz, à luz do caso concreto, possa controlar a licitude das deliberações assembleares sem que disso resulte violação da sistemática eleita pela lei.

Conclui-se, assim, que a teoria do "abuso do direito" ganhou nova importância para o direito concursal, sendo fundamental para resolver certos conflitos entre os interesses dos credores e do devedor, de modo a atender à função social da empresa, princípio maior da Lei ${ }^{\circ} 11.101 / 2005$.

${ }^{724}$ Cf. ARnOldo WALD e Ivo WAISBERG. In: Comentários... Op. cit., p. 321. 


\section{BIBLIOGRAFIA}

\section{Bibliografia citada}

ABRÃO, Carlos Henrique. In: Comentários à Lei de Recuperação de Empresas e Falência. 4 ed. Obra coletiva coordenada por ele e Paulo F. C. Salles de Toledo. São Paulo: Saraiva, 2012, p. 252-390.

ABRÃO, Nelson. A continuação do negócio na falência. São Paulo: Leud, 1975.

Os credores na falência. 2 ed. São Paulo: Leud, 1998.

Curso de direito falimentar. 5. ed. São Paulo: Leud, 1997.

ABREU, Jorge Manuel Coutinho de. Do Abuso de Direito. Coimbra: Almedina, p.65, 1999.

ADAMEK, Marcelo Von. Abuso de minoria em direito societário: abuso das posições subjetivas minoritárias. Tese de Doutorado, São Paulo: Faculdade de Direito da USP, 2010.

ALBERTI, Alberto Maffei. Commentario breve alla legge fallimentare. 4 ed. Milão: Cedam, 2000.

ALMEIDA, Amador Paes de. Curso de falência e recuperação de empresa. 24 ed. São Paulo: Saraiva, 2008.

AMERICANO, Jorge. Do abuso de direito no exercício da demanda. 2 ed. São Paulo: Saraiva, 1932.

ANCEL, Pascal; e DIDRY, Claude. "L'apparition de la notion d'abus em droit français au début du XXème siècle". In: L'abus de droit, comparaisons franco-suisses. Saint-Étienne: Université de Saint-Étienne, 2001, p. 51-66.

ANDRADE, Ronaldo Alves de. In: DE LUCCA, Newton; e SIMÃO FILHO, Adalberto. Comentários à Nova Lei de Recuperação de Empresas e Falências. São Paulo: Quartier Latin, 2005, p. 176-200.

ANDRIGHI, Fátima Nancy. In: CORRÊA-LIMA, Osmar Brina; e LIMA, Sérgio Mourão Correa (coord.). Comentários à nova Lei de Falência e Recuperação de Empresa. Rio de Janeiro: Forense, 2009, p. 489-519. 
APICE, Umberto. Soggetti e rapporti giuridici nelle procedure concorsuale. Milão: Cedam, 2002.

ARAGÃO, Paulo César. “Aspectos processuais da legislação societária”. Revista dos Tribunais, São Paulo, n. 641, p. 61 e seg., 1989.

; e BUCHAMAR, Laura. "A Assembléia Geral de Credores na Lei de Recuperação e Falências". In: SANTOS, Paulo Penalva (coord.). A nova lei de falências e de recuperação de empresas. Rio de Janeiro: Forense, 2007, p. 109-127.

ARAÚJO, José Francelino de. Comentários à Lei de Falência e Recuperação de Empresas. São Paulo: Saraiva, 2009.

ARECHA, Martín [et. al.]. El voto em las sociedades y los concursos. Buenos Aires: Legis Argentina, 2007.

ASCARELli, Tullio. Problemas das Sociedades Anônimas e Direito Comparado. 2 ed. São Paulo: Saraiva, 1969.

"O desenvolvimento histórico do direito comercial e o significado da unificação do direito privado". Revista de Direito Mercantil, Industrial, Econômico e Financeiro, São Paulo, n. 114, p. 237-252, 1999.

AZEVEDO, Álvaro Villaça. Código Civil Comentado. São Paulo: Atlas, 2003, v. 2.

AZZOLINA, Umberto. Il fallimento e le altre procedure concorsuali. 2 ed. Torino: UTET, 1961.

BAIRD, Douglas G.; JACKSON, Thomas H.; e ADLER, Barry E.. Bankruptcy, cases, problems and materials. 3 ed. New York: Foundation Press, 2000.

BAROSSI-FILHO, Milton. "As assembleias de credores e plano de recuperação de empresas: uma visão em teoria dos jogos". Revista de Direito Mercantil, Industrial, Econômico e Financeiro, São Paulo, n. 137, p. 233-238.

BARRICHELLO, Stefania Eugenia. "Análise econômica da nova lei brasileira de falência e recuperação de empresas". Revista de Direito Mercantil, Industrial, Econômico e Financeiro, São Paulo, n. 147, p. 195-209, 2007.

BARROSO, Luís Roberto. Curso de Direito Constitucional Contemporâneo. 2 ed. São Paulo: Saraiva, 2010.

BATALHA, Wilson de Souza Campos. Comentários à Lei das Sociedades Anônimas. Rio de Janeiro: Forense, 1977, v. 2. 
BATISTA, Carolina Soares João [et al.] "A prevalência da vontade da assembléia-geral de credores em questão: o cram down e a apreciação judicial do plano aprovado por todas as classes". Revista de Direito Mercantil, Industrial, Econômico e Financeiro, São Paulo, n. 143, p. 202-242, 2006.

BERGER, Dora. A insolvência no Brasil e na Alemanha. Porto Alegre: Sergio Antonio Fabris Editor, 2001.

BERNADI, Ricardo. In: SOUZA JUNIOR, Francisco Satiro; PITOMBO, Antônio Sérgio de Moraes (Coords.). Comentários à Lei de Recuperação de Empresas e Falências. São Paulo: Revista dos Tribunais, 2005, p. 475-494.

BERSANI, Giuseppe. Il concordato preventivo. Milão: Giuffrè, 2012.

BERTASI, Maria Odete Duque. MACHADO, Rubens Approbato (Coord.). Comentários à nova lei de falências e recuperação de empresas. 2 ed. São Paulo: Quartier Latin, 2007, p. 128-163.

BEVILAQUA, Clóvis. Código Civil dos Estados Unidos do Brasil. 3 ed. Rio de Janeiro: Livraria Francisco Alves, 1927, v. 1.

BEZERRA FILHO, Manoel Justino. "Exame crítico da lei de falências: recuperação de empresa ou recuperação do crédito bancário". Revista dos Tribunais, São Paulo, n. 138, p. 128-138, 2004.

2007.

Lei de recuperação de empresas e falências comentada. 4 ed. São Paulo: RT,

BIOLCHI, Osvaldo. In: TOLEDO, Paulo Campos Salles de; e ABRÃO, Carlos Henrique (coords.). Comentários à Lei de Recuperação de Empresas e Falência. 5 ed. São Paulo: Saraiva, 2012, p. 39-49.

BLUM, Brian A. Bankruptcy and debtor/creditor. Nova Iorque: Aspen Publishers, 1999.

BORBA, José Edwaldo Tavares. Direito Societário. 10 ed. Rio de Janeiro: Renovar, 2007.

BULGARELLI, Waldírio. Direito Comercial. 12. ed. São Paulo: Atlas, 1995.

BULHÕES PEDREIRA, Jose Luiz; e LAMY FILHO, Alfredo. A Lei das S.A. 3 ed. Rio de Janeiro: Renovar, 1997, v. 1. 
BULHÕES PEDREIRA, Luis Eduardo. In: LAMY FILHO, Alfredo; e BULHÕES PEDREIRA, José Luiz (Coords.). Direito das Companhias. Rio de Janeiro: Forense, 2009, v. 1, p. 326-376.

CAMPINHO, Sérgio. Falência e recuperação de empresa. Rio de Janeiro: Renovar, 2006.

CAMPION, L. La Théorie de L’Abus des Droits. Paris: Librairie Générale de Droit, 1925. p. 343.

CANDIAN, Aurelio. Il processo de concordato preventivo. Pádova: Antonio Milani, 1937.

CARPENA, Heloísa. "O abuso de direito no Código Civil de 2002: relativização de direitos na ótica civil constitucional". In: TEPEDINO, Gustavo (coord.). A parte geral do novo Código Civil: estudos na perspectiva civil constitucional. 3 ed. Rio de Janeiro: Renovar, 2007.

CARVALHO, Luiz Antônio da Costa. Falências e concordatas. Rio de Janeiro: A. Coelho Branco, 1947.

CARVALHO DE MENDONÇA, José Xavier. Tratado de Direito Comercial. Rio de Janeiro: Freitas Bastos, 1955. v. 7 e 8.

CARVAlHO SANTOS, J. M.. Código Civil brasileiro interpretado: Parte Geral (Arts. 144-179). Rio de Janeiro: Livraria Freitas Bastos, 1956. v. 3.

CARVAlHOSA, Modesto. Comentários à Lei de Sociedades Anônimas. 3 ed. São Paulo: Saraiva, 2003, v. 2

In: CORRÊA-LIMA, Osmar Brina; e LIMA, Sérgio Mourão Correa (coord.). Comentários à nova Lei de Falência e Recuperação de Empresa. Rio de Janeiro: Forense, 2009, p. 251-284.

CASTRO, Moema Augusta Soares de. In: CORREAA-LIMA, Osmar Brina; e LIMA, Sérgio Mourão Correa (coord.). Comentários à nova Lei de Falência e Recuperação de Empresa. Rio de Janeiro: Forense, 2009, p. 481-488.

CASTRO, Rodrigo R. Monteiro: ARAGÃO, Leandro Santos de (Coords.). Direito societário e a nova lei de falências e recuperação de empresas. São Paulo: Quartier Latin, 2006.

CEREZETTI, Sheila Christina Neder. "O papel dos credores no Bankruptcy Code". Revista de Direito Mercantil, Industrial, Econômico e Financeiro, São Paulo, n. 151/152, p. 164-186, 2009. 
COELHO, Eduardo de Melo Lucas. A Formação das Deliberações Gerais. Coimbra: Coimbra Editora, 1994.

COELHO, Fábio Ulhoa. Comentários à nova lei de falências e de recuperação de empresas. São Paulo: Saraiva, 2005.

. Curso de direito comercial: direito de empresa. 9. ed. São Paulo: Saraiva, 2008, v. 3.

. "Falência: principais alterações". Revista do Advogado, n. 83, p. 88.

COMPARATO, Fábio Konder. Aspectos jurídicos da macro-empresa. São Paulo: RT, 1970. Ensaios e pareceres de direito comercial. Rio de Janeiro: Forense, 1978.

. Novos Ensaios e Pareceres de Direito Empresarial. Rio de Janeiro: Forense, 1981.

1983.

O poder de controle na sociedade anônima. 3 ed. Rio de Janeiro: Forense, . “A reforma da empresa”. Revista Forense, Rio de Janeiro, n. 290, p. 9-20, 1985.

. Direito Empresarial: Estudos e Pareceres. São Paulo: Saraiva, 1990.

. "Estado, Empresa e função social". Revista dos Tribunais, São Paulo, v. 732, p. 38-46, 1996.

. "Direitos e deveres fundamentais em matéria de propriedade". Disponível em: http://daleth.cjf.jus.br/revista/numero3/artigo11.htm. Acesso em 02.07.2010.

CORRÊA-LIMA, Osmar Brina; e LIMA, Sérgio Mourão Correa (coord.). Comentários à nova Lei de Falência e Recuperação de Empresa. Rio de Janeiro: Forense, 2009.

COSTA, Luiz Antonio Silva. A lei de recuperação de empresas. São Paulo: Lex Editora, 2005.

COVAS, Silvânio. In: DE LUCCA, Newton; e SIMÃO FILHO, Adalberto. Comentários à Nova Lei de Recuperação de Empresas e Falências. São Paulo: Quartier Latin, 2005, p. 300-327.

DASSO, Ariel Ángel. Derecho concursal comparado. Bueno Aires: Legis Argentina, 2009, t. 1 e 2. 
DE LUCCA, Newton; SIMÃO FILHO, Adalberto (coord.). Comentários à nova lei de recuperação de empresas e de falências. São Paulo: Quartier Latin, 2005.

Latin, 2009.

; DOMINGUES, Alessandra de Azevedo (Coord.). Direito. São Paulo: Quartier

DELGADO, José Augusto. In: ALVIN, Arruda; WAMBIER; Teresa Alvim. (coords.). Comentários ao Código Civil brasileiro: dos fatos jurídicos. Rio de Janeiro: Forense, 2008. v. 2.

DESSERTEAUX, M. Marc. "Abus de Droit ou Conflit de Droits". Revue Trimestrielle de Droit Civil, 1906, p. 119-139.

DIAS, Aguiar. Da Responsabilidade Civil. 4 ed. Rio de Janeiro Forense, 1960. t. 2.

DINAMARCO, Cândido Rangel. Instituições de direito processual civil. São Paulo: Malheiros, 2001. v. 3.

DINIZ, Almachio. Da fallencia. São Paulo: Saraiva, 1930.

DINIZ, Maria Helena. In: FIUZA, Ricardo (coord. até a $5^{\mathrm{a}}$ ed.); TAVARES DA SILVA, Regina Beatriz (coord. da $6^{\text {a }}$ ed.). Código Civil comentado. 6 ed. São Paulo: Saraiva, 2008.

DUARTE, Nestor. In: PELUSO, César. Código Civil Comentado. Barueri: Manole, 2007, p. $15-154$.

FARENGA, Luigi. "La riforma del diritto fallimentare in Italia: uma nuova visione del mercato". Revista de Direito Privado, São Paulo, n. 145, p. 9-16, 2007.

FAZZIO JÚNIOR, Waldo. Lei de Falência e Recuperação de Empresas. 4 ed. São Paulo: Atlas, 2008.

FERRARA, Francesco. Il fallimento. Milão: Giuffrè, 1966.

FERRAZ JÚNIOR, Tercio Sampaio. Introdução ao estudo do direito. 2 ed. São Paulo: Atlas, 1994.

FERREIRA, Waldemar. Instituições de direito comercial. São Paulo: Freitas Bastos, 1951, v. 5. Tratado de Direito Comercial. São Paulo: Saraiva, 1966, v. 15 e 16.

FONSECA, Priscila M. P. Corrêa da. Suspensão de deliberações sociais. São Paulo: Saraiva, 1986. 
Atlas, 2009. v. 11.

Código Civil Comentado. In: AZEVEDO, Álvaro Villaça (coord.). São Paulo:

FRANÇA, Erasmo Valladão Azevedo e Novaes. Conflito de interesses nas assembléias de S/A. São Paulo: Malheiros, 1993.

1999.

Invalidade das deliberações de assembléia das S/A. São Paulo: Malheiros,

In: SOUZA JÚNIOR, Francisco Satiro de; PITOMBO, Antônio Sérgio de Moraes (Coords.). Comentários à Lei de Recuperação de Empresas e Falência. São Paulo: Revista dos Tribunais, 2005, p. 187-215.

$50,2005$.

“Assembléia-geral de credores". Revista do Advogado, São Paulo, n. 83, p. 42-

“A assembléia-geral de credores na nova lei falimentar". Revista de Direito Mercantil, Industrial, Econômico e Financeiro, São Paulo, n. 138, p. 71-83, 2005.

FRANÇA, Rubens Limongi. Princípios Gerais de Direito. 2. ed. São Paulo: RT, 1971.

n. 19, p. $40-45,1985$.

FRANCO, Vera Helena de Mello. “A função social da empresa”. Revista do Advogado, n. 96, p. 125-136, 2008.

; e SZTAJN, Rachel. Falência e recuperação da empresa em crise. Rio de Janeiro: Elsevier, 2008.

FRONTINI, Paulo Salvador. "O caso da falência da Sanderson e as tendências atuais do direito falimentar". Revista de Direito Mercantil, Industrial, Econômico e Financeiro, São Paulo, n. 15-16, p. 247-250, 1974.

. "Do Estado de Falido: sua configuração - Inovações da nova lei de recuperação e falência". Revista de Direito Mercantil, Industrial, Econômico e Financeiro, n. 138, p. 7-24, 2005.

GAGLIANO, Pablo Stolze [et. al.]. Novo Curso de Direito Civil. São Paulo: Saraiva, 2002. v. 1.

GALGANO, Francesco. Trattato di diritto civile. Milão: Cedam, 2010, v. 3 
GAMA, Guilherme Calmon Nogueira da; BARTHOLO, Bruno Paiva. "Função social da empresa". In: DELGADO, Mário Luiz; ALVES, Jones Figueiredo. Novo Código Civil: Questões controvertidas: direito de empresa. São Paulo: Método, 2010, p. 407-425.

GARDINO, Adriana Valéria Pugliesi. A evolução do tratamento jurídico da empresa em crise no direito brasileiro. Dissertação de Mestrado, São Paulo: Faculdade de Direito da USP, 2006.

GOMES, Orlando. Obrigações. 11 ed. Rio de Janeiro: Forense, 1997. Direito das Coisas. 13 ed. Rio de Janeiro: Forense, 1998. Introdução ao Direito Civil. 17 ed. Rio de Janeiro: Forense, 2000.

GONÇALVES NETO, Alfredo Assis. In: CORRÊA-LIMA, Osmar Brina; e LIMA, Sérgio Mourão Correa (coords.). Comentários à nova Lei de Falência e Recuperação de Empresa. Rio de Janeiro: Forense, 2009, p. 191-224.

GOUVÊA, João Bosco Cascardo de. Recuperação e Falência. Rio de Janeiro: Forense, 2009.

GUERREIRO, José Alexandre Tavares; TEIXEIRA, Egberto Lacerda. Das sociedades anônimas no direito brasileiro. São Paulo: Bushatsky, 1979. v. 1 e 2.

GUIMARÃES, Maria Celeste Morais. Recuperação judicial de empresas e falência. Belo Horizonte: Del Rey, 2007.

GUIMARÃES, Márcio. In: CORRÊA-LIMA, Osmar Brina; e LIMA, Sérgio Mourão Correa (coords.). Comentários à nova Lei de Falência e Recuperação de Empresa. Rio de Janeiro: Forense, 2009, p. 382-399.

HART, Oliver. Different Approaches to Bankruptcy. Disponível em: http://ww.nber.org/ papers/w7921, acesso em: 18.12.2012.

HOUAISS, Antônio. Dicionário Houaiss da Língua Portuguesa. Rio de Janeiro: Objetiva, 2001.

IMHOF, Cristiano. Lei de Falência e de Recuperação de Empresas e sua interpretação jurisprudencial. 2 ed. Balneário Camboriu: Publicações Online, 2012.

IRTI, Natalino. L'età della decodificazione. 4 ed. Milão: Giuffrè, 1999.

JORDÃO, Eduardo. Repensando a Teoria do Abuso de Direito. Salvador: JusPODIVUM, 2006. 
JORIO, Alberto. Le crisi d'impresa e il fallimento, Milão: Giuffrè, 2000.

JOSSERAND, Louis. De l'esprit de droits et de leur relativité: théorie dite de l'abus des droits. 2 ed. Paris: Dalloz, 1939.

JUNYENT BAS, Francisco; e SANDOVAL, Carlos A. Molina. Ley de Concursos y Quiebras Comentada. 2 ed. Buenos Aires: AbeledoPerrot, 2009, t. 1 e 2.

LACERDA, Paulo Maria de. Da fallencia no direito brasileiro. São Paulo: Cia. Editora Nacional, 1931.

LAMY FILHO, Alfredo; e BULHÕES PEDREIRA, José Luiz (Coords.). Direito das Companhias. Rio de Janeiro: Forense, 2009, v. 1.

LAZZARESCHI NETO, Alfredo Sérgio. Lei das Sociedades por Ações anotada. 4 ed. São Paulo: Saraiva, 2012.

LAZZARINI, Alexandre Alves. "Reflexões sobre a recuperação judicial de empresas". In: DOMINGUES, Alessandra de Azevedo (Coord.). Direito Recuperacional. São Paulo: Quartier Latin, 2009, p. 123-136.

LEÃES, Luiz Gastão Paes de Barros. "A disciplina do direito de empresa no novo Código Civil brasileiro". Revista de Direito Bancário e do Mercado de Capitais, São Paulo, n. 21, p. 48-63, 2003.

LEVADA, Cláudio Antônio Soares. O abuso e o novo direito civil brasileiro. Jundiaí: UniAnchieta, 2007.

LIMA, Sérgio Mourão Correa. In: CORRÊA-LIMA, Osmar Brina [et. al.]. Comentários à nova Lei de Falência e Recuperação de Empresa. Rio de Janeiro: Forense, 2009, p. 530622.

LO CASCIO, Giovanni. Il concordato preventivo. Milão: Giuffrè, 2011.

LOBATO, Moacyr. Falência e recuperação. Belo Horizonte: Del Rey, 2007.

LOBO, Jorge. Direito concursal. 2. ed. Rio de Janeiro: Forense, 1998.

In: TOLEDO, Paulo Campos Salles de; e ABRÃO, Carlos Henrique (coords.). Comentários à Lei de Recuperação de Empresas e Falência. São Paulo: Saraiva, 2005, p. 83-172.

LOTUFO, Renan. Código Civil Comentado. São Paulo: Saraiva, 2003, v. 1 
v. 1

. Curso Avançado de Direito Civil. 2 ed. São Paulo: Revista dos Tribunais, 2003.

LUCCA, Newton de; SIMÃO FILHO, Adalberto (coordenação). Comentários à Nova Lei de Recuperação de Empresas e de Falências: Lei n 11.101/2005. São Paulo: Quartier Latin, 2005.

LUNA, Everardo Cunha. Abuso de Direito. Rio de Janeiro: Forense, 1959.

MACHADO, Nelson Marcondes. "A Assembléia Geral de Credores e seus conflitos com a Assembléia Geral de Acionistas". In: CASTRO, Rodrigo R. Monteiro de; e ARAGÃO, Leandro Santos de (coords.). Direito societário e a nova lei de falências e recuperação de empresas. São Paulo: Quartier Latin, 2006, p. 147-162.

MACHADO, Rubens Approbato (Coord.). Comentários à nova lei de falências e recuperação de empresas. 2 ed. São Paulo: Quartier Latin, 2007.

MALHEIROS, Aristides. "Plano de recuperação: isso funciona?". Revista do Advogado, São Paulo, n. 105, p. 22.

MAMEDE, Gladston. Falência e recuperação de empresas. 3 ed. São Paulo: Atlas, 2009.

MANDEL, Julio Kahan. A Nova Lei de Falências e de Recuperações de Empresas Anotada. São Paulo: Saraiva, 2005.

MANGE, Eduardo Foz. Assembleia-Geral de Credores na recuperação judicial. Dissertação de mestrado, São Paulo: Faculdade de Direito da PUC-SP, 2010.

MARIANO, Álvaro A. C. Abuso de voto na recuperação judicial. Tese de doutoramento, São Paulo: Faculdade de Direito da USP, 2011.

MARZAGÃO, Lídia Valério. "A recuperação judicial”. In: MACHADO, Rubens Approbato (coord.). Comentários à nova lei de falências e recuperação de empresas. 2 ed. São Paulo: Quartier Latin, 2007.

MARTINS, Pedro Baptista. $O$ abuso do direito e o ato ilícito. 2 ed. Rio de Janeiro: Freitas Bastos, 1941.

MARTINS-COSTA, Judith. A Boa-Fé no Direito Privado. São Paulo: RT, 1999.

"Os avatares do Abuso do direito e o rumo indicado pela Boa-Fé". In: DELGADO, Mário Luiz; ALVES, Jones Figueirêdo. Novo Código Civil: questões controvertidas. São Paulo: Método, 2007. 
MAXIMILIANO, Carlos. Hermenêutica e aplicação do direito. 11. ed. Rio de Janeiro: Forense, 1990.

MEIRELLES, Hely Lopes. Direito Administrativo Brasileiro. 36 ed. São Paulo: Malheiros: 2010 .

MENDONÇA, José Xavier Carvalho de. Tratado de direito comercial brasileiro. 6. ed. Rio de Janeiro: Freitas Bastos, 1960, v. 7 e 8.

MENDONÇA DE MENEZES, Maurício Moreira. "Função sócio-econômica da empresa em recuperação". Revista Semestral de Direito Empresarial, Rio de Janeiro, n. 1, p. 49-86, 2007.

MENEZES DIREITO, Carlos Alberto. Comentários ao Novo Código Civil: Da responsabilidade civil. Das preferências e privilégios creditórios. Coord. de Sálvio Figueiredo Teixeira. Rio de Janeiro: Forense, 2004. v. 13.

MILANI, Mario Sergio. Lei de recuperação judicial, recuperação extrajudicial e falência comentada. São Paulo: Malheiros, 2011.

MIRANDA JÚNIOR, Darcy Arruda. Breves comentários à lei de sociedades por ações. São Paulo: Saraiva, 1977.

MONTEIRO, Washington de Barros. Curso de direito civil. 33 ed. São Paulo: Saraiva, 1995, v. 1.

MOREIRA, Alberto Camiña. "Poderes da assembléia de credores, do juiz e atividade do Ministério Público". In: PAIVA, Luiz Fernando Valente de (coord.). Direito Falimentar e a Nova Lei de Falências e Recuperação de Empresas. São Paulo: Quartier Latin, 2005. p. 247-274.

MUNHOZ, Eduardo Secchi. "Anotações sobre os limites do poder jurisdicional na apreciação do plano de recuperação judicial”. Revista de Direito Bancário e do Mercado de Capitais, n. 36, p. 184-199, 2007.

In: SOUZA JUNIOR, Francisco Satiro; PITOMBO, Antônio Sérgio de Moraes (Coords.). Comentários à Lei de Recuperação de Empresas e Falências. São Paulo: Revista dos Tribunais, 2005, p. 269-313.

NALINI, José Renato. Ética Geral e Profissional. 8 ed. São Paulo: Revista dos Tribunais, 2011.

NARDECCHIA, Giovanni Battista. Gli effetti del concordato preventivo sui creditori. Milão: IPSOA, 2011. 
NASCIMENTO, Amauri Mascaro. Curso de Direito do Trabalho. 26 ed. São Paulo: Saraiva, 2011.

NEGRÃO, Ricardo. Aspectos objetivos da lei de recuperação de empresas e de falências. São Paulo: Saraiva, 2008.

Saraiva, 2010.

A eficiência do processo judicial na recuperação de empresa. São Paulo:

NETTO, Nelson Rodrigues [et. al.]. Comentários à Lei de Recuperação Judicial de Empresas e Falência. 4 ed. São Paulo: LTr, 2007.

OLIVEIRA, Eduardo Ribeiro de. Comentários ao Novo Código Civil. 2 ed. Coleção coordenada por Sálvio de Figueiredo Teixeira. Rio de Janeiro: Forense, v. 2.

PACHECO, José da Silva. Tratado das execuções: falência e concordata. São Paulo: Saraiva, 1977.

Processo de falência e concordata. 8 ed. Rio de Janeiro: Forense, 1998.

Processo de recuperação judicial, extrajudicial e falência. 3. ed. Rio de Janeiro: Forense, 2009.

PAILlUSSEAU, J. Du droit des faillites au droit des entreprises en difficulté. Paris: Dalloz, 1985.

PAIVA, Luiz Fernando Valente de. Direito Falimentar e a Nova Lei de Falências e Recuperação de Empresas. São Paulo: Quartier Latin, 2005.

. "Apresentação do plano de recuperação pelo devedor e a atuação dos credores". Revista do Advogado, São Paulo, n. 83, p. 73-81, 2005.

; e COLOMBO, Giuliano. "Recuperação judicial e cessão de créditos: a polêmica do direito de voto". Revista do Advogado, São Paulo, n. 105, p. 107-114, 2009.

PEIXOTO, Euler da Cunha. In: CORRÊA-LIMA, Osmar Brina; CORRÊA-LIMA, Sérgio Mourão. Comentários à Nova Lei de Falência e Recuperação de Empresas. Rio de Janeiro: Forense, 2009, p. 962-999.

PENTEADO, Mauro Rodrigues. In: SOUZA JUNIOR, Francisco Satiro; PITOMBO, Antônio Sérgio de Moraes (Coords.). Comentários à Lei de Recuperação de Empresas e Falência. São Paulo: RT, 2005. 
In: CORRÊA-LIMA, Osmar Brina; CORRÊA-LIMA, Sérgio Mourão. Comentários à Nova Lei de Falência e Recuperação de Empresas. Rio de Janeiro: Forense, 2009, p. 159-190.

PEREIRA, Caio Mario da Silva. Direito Civil - Alguns aspectos de sua evolução. Rio de Janeiro: Forense, 2001.

Instituições de Direito Civil. 8. ed., Rio de Janeiro: Forense, 1995, v. 1.

Responsabilidade civil. 7 ed. Rio de Janeiro: Forense, 1996.

PERIN JUNIOR, Ecio. Preservação da Empresa na Lei de Falências. Saraiva, 2009.

Curso de Direito Falimentar e Recuperação de Empresas. 3 ed. São Paulo: Método, 2006.

PLANIOL, Marcel. Traité élémentaire de droit civil. 4 ed. Paris: Librairie Géneraçe de Droit \& de Jurisprudence, 1907, t. 2.

PONTES DE MIRANDA, Francisco. Tratado de Direito Privado. 2 ed. Rio de Janeiro: Borsoi, 1960, t. 3, 27, 28, 50 e 53.

PROVINCIALI, Renzo. Trattato di diritto fallimentare. Milão: Giuffrè, 1974.

REALE, Miguel. Lições preliminares de direito. 20 ed. São Paulo: Saraiva, 1993.

"A boa-fé no Código Civil". Revista de Direito Bancário e do Mercado de Capitais, São Paulo, n. 21, p. 11-13, 2003.

REGO, Marcelo Lamy. LAMY FILHO, Alfredo; e BULHÕES PEDREIRA, José Luiz (Coords.). Direito das Companhias. Rio de Janeiro: Forense, 2009, v. 1, p. 377-429.

REQUIÃO, Rubens. "A crise do direito falimentar brasileiro: reforma da lei de falências". Revista de Direito Mercantil, Industrial, Econômico e Financeiro, São Paulo, n. 14, p. 2333, 1974.

. Curso de Direito Falimentar. 17 ed. São Paulo: Saraiva, 1998, v. 1 e 2.

RESTIFFE, Paulo Sérgio. Recuperação de empresas. Barueri: Manole, 2008.

RIBEIRO, Renato Ventura. “Abuso de Direito”. In: REALE, Miguel. (coord). Experiência do direito. Campinas-SP: Millennium, 2004, p. 191-228. 
Direito de Voto nas Sociedades Anônimas. São Paulo: Quartier Latin, 2009.

RIPERT, Georges. Aspects juridiques du capitalisme moderne. Paris: Librairie Générale de Droit et de Jurisprudence, 1946.

RODRIGUES, Silvio. Curso de direito civil. 3 ed. São Paulo: Saraiva, 1977, v. 4.

Curso de direito civil. 19 ed. São Paulo: Saraiva, 2002, v. 4.

SÁ, Fernando Augusto Cunha de. Abuso do Direito. Coimbra: Almedina, 1997.

SADDI, Jairo. In: PAIVA, Luiz Fernando Valente de (coord.). Direito falimentar na nova lei de falências e recuperação de empresas. São Paulo: Quartier Latin, 2005.

"Suspensão e invalidação da assembléia geral de credores na nova lei de falências". In: CASTRO, Rodrigo R. Monteiro de; e ARAGÃO, Leandro Santos de (coords.). Direito societário e a nova lei de falências e recuperação de empresas. São Paulo: Quartier Latin, 2006, p. 23-55.

- "Assembléia de credores: um ano de experiência na nova Lei de Falências. Uma avaliação". Revista de Direito Bancário e do Mercado de Capitais, São Paulo, n. 37, p. 214-223, 2007.

In: CORRÊA-LIMA, Osmar Brina; e LIMA, Sérgio Mourão Correa (coords.). Comentários à nova Lei de Falência e Recuperação de Empresa. Rio de Janeiro: Forense, 2009, p. 285-312 e 1272-1286.

SAMPAIO DE LACERDA, José Cândido. Manual de Direito Falimentar. 7 ed. Rio de Janeiro: Freitas Bastos, 1972.

SANTOS, Paulo Penalva (Coord.). A Nova Lei de Falências e de Recuperações de Empresas. Rio de Janeiro: Forense, 2006.

SATIRO DE SOUZA JR., Francisco; e PITOMBO, Antonio Sergio A. de Moraes (Coords.). Comentários à Lei de Recuperação de Empresas e Falência. São Paulo: RT, 2005.

SENA, Giuseppe. Il voto nella assemblea della società per azioni. Milão: Giuffrè, 1958.

SIMÃO FILHO, Adalberto. In: DE LUCCA, Newton; e SIMÃO FILHO, Adalberto. Comentários à Nova Lei de Recuperação de Empresas e Falências. São Paulo: Quartier Latin, 2005, p. 389-454. 
"Interesses transindividuais dos credores nas Assembléias-Gerais e sistemas de aprovação do plano de recuperação judicial". In: DE LUCCA, Newton; e DOMINGUES, Alessandra de Azevedo (Coords.). Direito recuperacional. São Paulo: Quartier Latin, 2009, p. 31-64.

. "O espírito da Lei de Recuperação de Empresas e de Falência". Disponível em: http://www.conpedi.org.br/manaus/arquivos/anais/brasilia/01_195.pdf. Acesso em: 16.12. 2012.

SIMIONATO, Frederico A. Monte. Tratado de direito falimentar. Rio de Janeiro: Forense, 2008.

SOUZA JÚNIOR, Francisco Satiro de; e PITOMBO, Antônio Sérgio de Moraes (Coords.). Comentários à Lei de Recuperação de Empresas e Falência. São Paulo: Revista dos Tribunais, 2005.

SZTAJN, Rachel. In: SOUZA JÚNIOR, Francisco Satiro de; e PITOMBO, Antônio Sérgio de Moraes (Coords.). Comentários à Lei de Recuperação de Empresas e Falência. São Paulo: Revista dos Tribunais, 2005, p. 217-268.

. "Notas sobre as assembléias de credores na lei de recuperação de empresas". Revista de Direito Mercantil, Industrial, Econômico e Financeiro, São Paulo, n. 138, p. 5370, 2005.

TABB, Charles Jordan. The Law of Bankruptcy. Nova Iorque: The Foundation Press, 1997.

TARTUCE, Flávio. "Considerações sobre o abuso de direito ou ato emulativo civil". In: DELGADO, Mário Luiz; ALVES, Jones Figueirêdo. Novo Código Civil: questões controvertidas. São Paulo: Método, 2004.

TEPEDINO, Gustavo [et. al]. Código Civil interpretado. R. Janeiro: Renovar, 2004, v. 1.

. (Coord.) A parte geral do novo Código Civil: estudos na perspectiva civil constitucional. 3 ed. Rio de Janeiro: Renovar, 2007.

Comentários ao Novo Código Civil. Coleção coordenada por Sálvio de Figueiredo Teixeira. Rio de Janeiro: Forense, 2008. v. 10.

TEPEDINO, Ricardo. "A recuperação da empresa em crise diante do Decreto-lei 7.661/1945". Revista de Direito Mercantil, Industrial, Econômico e Financeiro, São Paulo, n. 128 , p. 165-173, 2002.

In: LAMY FILHO, Alfredo; e BULHÕES PEDREIRA, José Luiz (Coords.). Direito das Companhias. Rio de Janeiro: Forense, 2009, v. 1, p. 871-1026. 
THEODORO JÚNIOR, Humberto. Comentários ao Novo Código Civil. 2 ed. Coleção coordenada por Sálvio de Figueiredo Teixeira. Rio de Janeiro: Forense, 2003. v. 3, t. 2.

. Curso de Direito Processual Civil. 48 ed. Rio de Janeiro: Forense, 2008.

TOLEDO, Paulo Fernando Campos Salles de. A empresa em crise no direito francês e americano. Dissertação de Mestrado, São Paulo: Faculdade de Direito da USP, 1987.

"A disciplina jurídica das empresas em crise no Brasil: sua estrutura institucional". Revista de Direito Mercantil, Industrial, Econômico e Financeiro, São Paulo, n. 122, p. 168-172, 2001.

"Recuperação judicial: a principal inovação da Lei de Recuperação de Empresas - LRE”. Revista do Advogado, São Paulo, n. 83, p. 98-106, 2005.

; e ABRÃO, Carlos Henrique (coords.). Comentários à Lei de Recuperação de Empresas e Falência. 5 ed. São Paulo: Saraiva, 2012.

"Recuperação judicial - sociedades anônimas - debêntures - assembléia geral de credores - liberdade de associação - boa-fé objetiva - abuso de direito - cram down - par condicio creditorum." Revista de Direito Mercantil, Industrial, Econômico e Financeiro, São Paulo, n. 142, p. 263-281, 2006.

TOMASEVICIUS FILHO, Eduardo. "Função social da empresa". Revista dos Tribunais, São Paulo, n. 810, p. 33-50, 2003.

TOMAZETTE, Marlon. Curso de direito empresarial. São Paulo: Atlas, 2011, v. 3.

TRUFFAT, Daniel. "No existe em el derecho argentino nada que pueda denominarse 'derecho de voto' em lo referido a la solución concordataria". In: ARECHA, Martin (Coord.). El voto em las sociedades y los concursos. Buenos Aires: Legis Argentina, 2007, p. $233-250$.

VALVERDE, Trajano de Miranda. A fallencia no direito brasileiro. Rio de Janeiro: Freitas Bastos, 1931, v. 1, 2 e 3.

Comentários à Lei de Falências. Rio de Janeiro: Forense, 1999, v.1, 2 e 3.

VERÇOSA, Haroldo Malheiros Duclerc. In: SOUZA JÚNIOR, Francisco Satiro de; PITOMBO, Antônio Sérgio de Moraes (Coords.). Comentários à Lei de Recuperação de Empresas e Falência. São Paulo: Revista dos Tribunais, 2005, p. 163-186.

"O status jurídico do controlador e dos administradores na recuperação judicial" Revista de Direito Mercantil Industrial, Econômico e Financeiro, São Paulo, n. 143, p. 2139, 2006. 
VIGIL NETO, Luiz Inácio. Teoria falimentar e regimes recuperatórios. Porto Alegre: Livraria do Advogado, 2008.

VÍTOLO, Daniel Roque. Acuerdos preventivos abusivos o en fraude a la ley. Santa Fé: Rubinzal Culzoni, 2009.

WALD, Arnoldo. Comentários ao novo código civil. Coord. de Sálvio de Figueiredo Teixeira. Do direito de empresa. Rio de Janeiro: Forense, 2005, v. 19.

; e WAISBERG, Ivo. In: CORRÊA-LIMA, Osmar Brina; e LIMA, Sérgio Mourão Correa (coord.). Comentários à nova Lei de Falência e Recuperação de Empresa. Rio de Janeiro: Forense, 2009, p. 313-352.

ZANINI, Carlos Klein. In: SOUZA JÚNIOR, Francisco Satiro de; PITOMBO, Antônio Sérgio de Moraes (Coords.). Comentários à Lei de Recuperação de Empresas e Falência. São Paulo: Revista dos Tribunais, 2005, p. 314-352.

\section{Bibliografia consultada}

ABRÃO, Carlos Henrique. "Os créditos bancários e a recuperação da empresa". Revista de Direito Bancário e do Mercado de Capitais, São Paulo, n. 3, p. 78-82, 1998.

. "A preservação e a recuperação da empresa em crise". Revista dos Tribunais, São Paulo, n. 822, p. 106-109, 2004.

ABRÃO, Nelson. O Novo Direito Falimentar: Nova Disciplina Jurídica da Crise Econômica da Empresa. São Paulo: RT, 1985.

AGUIAR JÚNIOR, Ruy Rosado de. "Projeto do Código Civil: as obrigações e os contratos". Revista dos Tribunais, São Paulo, n. 775, p. 18-31, 2000.

. "O Poder Judiciário e a concretização das cláusulas gerais: limites e responsabilidade”. Revista de Direito Renovar, Rio de Janeiro, n. 18, p. 11-19, 2000.

. "Responsabilidade política e social dos juízes nas democracias modernas". Revista Jurídica, Porto Alegre, n. 350, p. 213-235, 2006.

ALEXY, Robert. Teoria da Argumentação Jurídica. Trad. de Zilda Hutchinson Schild Silva. São Paulo: Landy Editora, 2001. 
ARNOLDI, Paulo Roberto Colombo. "Análise ecônomico-jurídica da lei de falências e de recuperação de empresas de 2005". Revista de Direito Privado, São Paulo, n. 24, p. 220234, 2005.

ASCARELLI, Tullio. Corso di diritto fallimentare. Milão: Giuffrè, 1962.

ASQUINI, Alberto. "Os perfis da empresa". Trad. Fabio Konder Comparato. Revista de Direito Mercantil, Industrial, Econômico e Financeiro, São Paulo, n. 104, p. 109-126, 1996.

ÁVILA, Humberto. Teoria dos Princípios. 5 ed. São Paulo: Malheiros, 2006.

AZEVEDO, Antônio Junqueira de. Negócio Jurídico. Existência, validade e eficácia. 4. ed. São Paulo: Saraiva, 2002.

BARRETO FILHO, Oscar. "Síntese da evolução histórica do Direito Comercial brasileiro". Revista de Direito Mercantil, Industrial, Econômico e Financeiro, São Paulo, n. 24, p. 23-27, 1976.

BERGER, Dora. A insolvência no Brasil e na Alemanha. Porto Alegre: Sergio Antonio Fabris Editor, 2001.

BEZERRA FILHO, Manoel Justino. Lei de Falências comentada. São Paulo: RT, 2001. $\overline{\mathrm{RT}, 2006 .}$ Jurisprudência da nova lei de recuperação de empresas e falências. São Paulo:

BISBAL MÉNDEZ, Joaquim. La empresa em crisis y el derecho de quiebras. Bolonia: Publicaciones del Real Colegio de Espana, 1986.

BOBBIO, Norberto. Teoria do ordenamento jurídico. Trad. de Maria Celeste de J. Santos. 10 ed. Editora Universidade de Brasília, 1999.

Teoria da norma jurídica. Trad. de Fernando Pavan Baptista e Ariani Bueno Sudatti. 4. ed. rev. Bauru: Edipro, 2008.

BULGARELLI, Waldírio. A reforma da Lei das Falências e Concordatas. Revista de Direito Mercantil, Industrial, Econômico e Financeiro, São Paulo, n. 85, p. 49-56, 1992.

CARVALHO DE MENDONÇA, José Xavier. Pareceres: fallencias. Rio de Janeiro: Freitas Bastos, 1933.

CAVALIERI FILHO, Sérgio. Programa de Sociologia Jurídica. 12 ed. Rio de Janeiro: Forense, 2010. 
CENSONI, Paolo Felice. Manuale di diritto fallimentare. Milão: Cedam, 2004.

CEREZETTI, Sheila Christina Neder. A lei de recuperação e falência e o princípio da preservação da empresa: uma análise da proteção aos interesses envolvidos pela sociedade por ações em recuperação judicial. Tese de doutorado, São Paulo: Faculdade de Direito da USP, 2009.

COPPENS, Pierre. L'abus de majorité dans lês Sociétés Anonymes. Louvain: Librairie René Fonteyn, 1955.

CORRÊA-LIMA, Osmar Brina. "Questões polêmicas da nova lei de falências”. Revista de Direito Empresarial, Curitiba, n. 3, p. 9-24, 2005.

DALLARI, Dalmo de Abreu. O poder dos juizes. São Paulo: Saraiva, 1996.

ESTRADA, Federico. El acreedor en el concurso preventivo. Buenos Aires: Errepar, 2005.

FERRI, Giuseppe. Manuale di dirirro commerciale. 9 ed. Turim: UTET, 1993.

FRISHTAK, Claudio (Org.). Regulatory policies and reform: a comparative perspective. Washington: The World Bank, 1995.

GORON, Lívio Goellner. "Anotações sobre a boa-fé no Direito Comercial”. Revista de Direito Privado, São Paulo, n. 13, p.143-158, 2006.

HAYEK, Friedrich August. Law, legislation and liberty: the mirage of social justice. Chicago: University of Chicago Press, 1978.

HART, Herbert L. A. O conceito de direito. 3 ed. Tradução de A. Ribeiro Mendes. Lisboa: Fundação Caloust Gulbenkian, 2001.

HEREDIA, Pablo D. Tratado exegético de derecho concursal. Buenos Aires: Ábaco, 2000, t. 2 .

JORDAN, Robert L.; WARREN, William D. Bankruptcy. 5 ed. Nova Iorque: The Foundation Press, 1999.

LOBO, Jorge. Da Recuperação da Empresa no Direito Comparado. Rio de Janeiro: Lúmen Júris, 1993.

. "Direito da crise econômica da empresa". Revista dos Tribunais, São Paulo, n. 754, p. 11-44, 1998.

LUCENA, José Waldecy. Das sociedades limitadas. 5. ed. Rio de Janeiro: Renovar, 2003. 
MARCONDES, Sylvio. Problemas de direito mercantil. São Paulo: Max Limonade, 1970.

MOREIRA ALVES, José Carlos. "A unificação do direito privado brasileiro - de Teixeira de Freitas ao novo Código Civil". In: AZEVEDO, Antônio Junqueira de [et. al.] (coords.). Princípios do Novo Código Civil Brasileiro e Outros Temas: homenagem a Tullio Ascarelli. São Paulo: Quartier Latin, 2008, p. 363-421.

MORRIS, Clarence (org.). Os grandes filósofos do direito. São Paulo: Martins Fontes, 2002.

NALINI, José Renato. Ética da Magistratura. 2 ed. São Paulo: Revista dos Tribunais, 2011.

NUNES, Márcio Tadeu Guimarães. Desconstruindo a desconsideração da personalidade jurídica. São Paulo: Quartier Latin, 2007.

PAJARDI, Piero. Manuale del Diritto Fallimentare. 4ª ed. Milão: Giuffrè, 1993.

PENTEADO, Mauro Rodrigues. Aumentos de Capital das Sociedades Anônimas. São Paulo: Saraiva, 1988.

PONTES DE MIRANDA, Francisco. Tratado de Direito Privado. 2 ed. Rio de Janeiro: Borsoi, 1960, t. 1, 2, 4, 29 e 30.

POSNER, Richard A.; e ADLER, Barry. Corporate bankruptcy, economic and legal perspectives. Cambridge: Cambridge University Press, 1996.

REALE, Miguel. Filosofia do Direito. 6 ed. São Paulo: Saraiva, 1972, v. 1 e 2. Teoria Tridimensional do Direito. 5 ed. São Paulo: Saraiva, 2000. História do novo Código Civil. São Paulo: RT, 2005.

REQUIÃO, Rubens. "Insolvência e preservação da empresa”, In: Aspectos modernos de direito comercial, São Paulo, Saraiva, 1986.

RODRIGUES, Frederico Viana. "Reflexões sobre a viabilidade econômica da empresa no novo regime concursal brasileiro". Revista de Direito Mercantil, Industrial, Econômico e Financeiro, n. 138, p. 102-122, 2005.

ROQUE, Sebastião José. Direito de Recuperação de empresas. São Paulo: Ícone, 2005,

SADDI, Jairo. Crédito e Judiciário no Brasil: uma análise de direito \& economia. São Paulo: Quartier Latin, 2007. 
SATTA, Salvatore. Diritto fallimentare. 3. ed. Pádua: Cedam, 1996.

SIMIONATO, Frederico A. Monte. "O interesse social como interesse da empresa em si". Revista de Direito Empresarial, Curitiba, n. 2, p. 9-22, 2004.

SOARES DE FARIA, Sebastião. Da concordata terminativa da fallencia. São Paulo: Saraiva, 1928.

Da concordata preventiva da fallencia. São Paulo: Saraiva, 1932.

TOMASETTI JÚNIOR, Alcides. "Abuso de poder econômico e abuso de poder contratual.” Revista dos Tribunais, São Paulo, n. 715, p. 87-107, 1995.

"A propriedade privada entre o direito civil e a Constituição". Revista de Direito Mercantil Industrial, Econômico e Financeiro, São Paulo, n. 126, p. 123-127, 2002.

VAISER, Lidia. El abuso del derecho en los procesos concursales. Buenos Aires: Ad-hoc, 2008.

VAMPRÉ, Spencer. Repertório Geral de Jurisprudência, Doutrina e Legislação: da fallencia e da concordata. São Paulo: Saraiva, 1925, v. 3.

VASCONCELOS, Ronaldo. Direito processual falimentar. São Paulo: Quartier Latin, 2008 .

ZILBERBERG, Eduardo. "Uma análise do princípio da preservação da empresa viável no contexto da nova lei de recuperação de empresa". Revista de Direito Mercantil, Industrial, Econômico e Financeiro, São Paulo, n. 141, p. 185-191, 2006. 